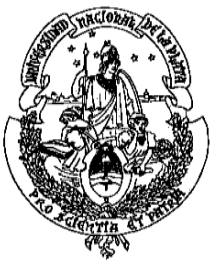

Universidad Nacional de La Plata - Facultad de Arquitectura y Urbanismo

Maestría "Paisaje, Medio ambiente y Ciudad"

Programa Alfa II

Tesis para optar al título de magíster en Paisaje, Medio ambiente y Ciudad

\title{
El paisaje de borde urbano
}

Trayectorias semióticas de los discursos de construcción de la ciudad de Medellín

Autor: César Augusto Salazar Hernández,

Director: Dr.Beethoven Zuleta, historiador (profesor asociado Universidad Nacional de Colombia)

Codirector: Alberto Pérez, Licenciado en Filosofía (profesor Universidad Nacional de La Plata)

La Plata, Argentina, 2012 


\section{ÍNDICE}

NOTA DE AGRADECIMIENTO

\section{CAPÍTULO 1. EL PLANTEAMIENTO Y LOS ANTECEDENTES DEL PROBLEMA DE INVESTIGACIÓN}

1.1 El borde urbano en Medellín. Registro o antecedentes de una ciudad que se transforma

1.1.1 Del paisaje pueblerino a la incorporación de elementos simbólicos detonadores de la expansión urbana. Medellín, 1870-1925

- La primera expansión urbana de Medellín y la incorporación de nuevos elementos simbólicos en el paisaje urbano. Medellín, 1890-1910

- La plaza de mercado cubierta y el ferrocarril. Detonadores de la expansión urbana y de nuevas pautas de comportamiento social. Medellín 1910-1925

1.1.2 El salto de la ciudad hacia el occidente y el inicio de un crecimiento desbordado. Medellín, 19251970

- El salto de la ciudad a la otra banda del río y el surgimiento de una nueva ciudad trazada bajo las influencias de movimientos de la época. Medellín 1940-1950

- Una ciudad compleja para su administración y para la percepción de sus ciudadanos. Medellín, 1950-1970

1.1.3 La ciudad producto de la máxima renta, de la segregación y de las pretensiones de internacionalización. Medellín, 1970-2010

- La consolidación de un modelo de segregación urbana. Medellín, 1985-2000 23

- Actuaciones urbanas para la entrada al club de ciudades marketing. Medellín 2000-2010 24

1.2 Estado del arte documental y bibliográfico y objetivos de la investigación

- Ir a los paisajes de borde urbano. Una búsqueda para comprender las lógicas de producción del paisaje urbano

- Objetivos o propósitos de la investigación

\section{CAPÍTULO 2. FUNDAMENTACIÓN TEÓRICA, HIPÓTESIS Y METODOLOGÍA DE LA INVESTIGACIÓN

2.1 Por la construcción de una teoría narrativa del paisaje $\quad 33$

- La anamnesis y la amnesia urbana 34

- La ciudad, escenario de recurrencias y de itinerarios de la memoria 36

- Las fotografías: registro de experiencias capturadas 37

- Los estratos narrativos en la lectura del paisaje 39

2.2 Metodología de la investigación: El borde urbano, un vector semiótico transgresor. Hipótesis o presupuesto de partida en la investigación $\quad 41$

- Categorías para la comprensión de los cambios producidos en el los bordes urbanos 44

- Categorías para renombrar las escenas que ofrece el paisaje contemporáneo 44

- Estrategia narrativa o sistematización de las evidencias iconográficas 45

2.3 Instrumentos para la lectura de la transformación del paisaje de borde urbano 46

- Matriz de la expansión urbana para el inventario de objetos que configuran el paisaje urbano

- Muestreo regularizado. Mosaico de imágenes 47 
- La fotografía como instrumento para recoger la visión de la realidad social

\section{CAPÍTULO 3. DESARROLLO DE LA INVESTIGACIÓN}

3.1 Lectura horizontal del proceso de configuración del paisaje urbano de Medellín

3.1.1 Estratos narrativos producidos entre 1870 y 1925

- El paisaje del hombre rural urbanizado o rezagos del paisaje colonial 53

- Paisaje ambivalente o de la transición entre lo colonial y lo burgués $\quad 55$

- Paisajes del comercio, del ocio y de los itinerarios desplegados 59

$\begin{array}{ll}\text { 3.1.2 Estratos narrativos producidos entre } 1925 \text { y } 1970 & 61\end{array}$

- Paisaje de la disciplina y el orden moral cívico 61

- Paisaje de escape 65

- Paisaje intimidante y apabullante 68

3.1.3 Estratos narrativos producidos entre 1970 y $2010 \quad 74$

- Paisaje de lo ocultado o de lo invisibilizado 74

- Paisaje reducido y de la pérdida de valores urbanos 75

- Paisaje del ensimismamiento o la reclusión 76

3.2 Lectura del paisaje en su mosaico actual, desde el eje vertical o desde la colonización de los

elementos-iconos sobre el espacio urbano $\quad 78$

3.2.1 Identificación de los tipos de borde, característicos en el paisaje urbano de Medellín $\quad 79$

- Recorrido por el paisaje urbano contemporáneo de Medellín a través de los estratos narrativos de 1870-1890, 1890-1910 y 1910-1925 80

- Recorrido por el paisaje urbano contemporáneo de Medellín a través de los estratos narrativos de 1925-1940, 1940-1950 y 1950-1970

- Recorrido por el paisaje urbano contemporáneo de Medellín a través de los estratos narrativos de 1970-1985, 1985-1996 y 1996-2010 86

3.3 Los tipos de bordes urbanos plegados o de plegamiento 90

$\begin{array}{lr}\text { 3.3.1 Borde urbano plegado conglomerado } & 90\end{array}$

$\begin{array}{ll}\text { 3.3.2 Borde urbano plegado integrado } & 94\end{array}$

$\begin{array}{ll}\text { 3.3.3 Borde urbano plegado aglutinante } & 97\end{array}$

3.3.4 Borde urbano plegado jerarquizado 98

$\begin{array}{ll}\text { 3.3.5 Borde urbano plegado alongado } & 101\end{array}$

$\begin{array}{ll}\text { 3.3.6 Borde urbano plegado absorbente } & 103\end{array}$

3.4 Bordes urbanos sedimentados $\quad 109$

3.4.1 Borde urbano sedimentado amontonado 109

$\begin{array}{ll}\text { 3.4.2 Borde urbano sedimentado desperdigado } & 111\end{array}$

$\begin{array}{ll}\text { 3.4.3 Borde urbano sedimentado desagregado } & 114\end{array}$

3.4.4 Borde urbano sedimentado saturado $\quad 118$

3.5 Incidencia de la forma de los tipos de borde urbano en la calidad del paisaje $\quad 119$

$\begin{array}{ll}\text { 3.5.1 La compacidad urbana en los tipos de borde urbano } & 120\end{array}$

- Cálculo del índice de compacidad absoluta 121

- Cálculo del índice de compacidad corregida 121

- Cálculo del índice de compacidad ponderada $\quad 122$

3.5.2 La complejidad urbana en los tipos de borde urbano 130

3.5.3 Análisis axial en relación con los bordes urbanos 136 


\section{CAPÍTULO 4. CONCLUSIONES DE LA INVESTIGACIÓN}

POR UNA GESTIÓN DE LA TRANSFORMACIÓN DEL PAISAJE

4.1 El mosaico de imágenes que nos ofrece la transformación del paisaje de borde urbano

- Del paisaje arborescente al paisaje absorbido por el concreto. $\mathrm{O}$ del parque burgués al parque temático

- El proyecto inmobiliario contemporáneo. Un paisaje sin un proyecto político y sin una propuesta hacia lo público

- La imposición del elemento arquitectónico sobre el urbanismo. La escasez o la reducción de la narrativa en el paisaje

- La caricatura patrimonial o la política de convertir lo viejo en adorno o en ruina

- La imposición de unas mínimas rutinas, o modulaciones del tiempo, ante la diversa proliferación de itinerarios que producen los distintos actores urbanos

- Refacturar la forma urbana a partir del reciclaje de las imágenes que ofrecen los estratos narrativos del paisaje urbano

- Descubrir y elaborar nuevos argumentos narrativos y compositivos para un paisaje más diverso

- Revitalizar la relación naturaleza-ciudad, revisando las representaciones y las prácticas de ésta en los diferentes escenarios urbanos

- Por una política del tiempo que promueva el discurrir de las diferentes trayectorias que trazan los distintos sujetos del paisaje.

ANEXOS

\section{ÍNDICE DE ILUSTRACIONES}

Ilustración 1. Crecimiento de la extensión urbana de Medellín entre 1870 y 1932.

Ilustración 2. Artículo de la prensa nacional en 1953 relacionado a la expansión urbana del occidente de Medellín

Ilustración 3. Publicidad de nuevos proyectos del sector inmobiliario en el suroccidente de Medellín. En esta se refieren a un sector llamado Metrópolis, contiguo a un barrio (antiguo palenque) denominado tradicionalmente El Rincón

Ilustración 4. Promoción de la ciudad de Medellín en el portal electrónico del municipio....................................26

Ilustración 5. Información cartográfica que muestra la evolución del crecimiento urbano de Medellín.................28

Ilustración 6. Mapa síntesis del proceso de expansión urbana de Medellín desde 1870 al 2006........................... 30

Ilustración 7. Imágenes del archivo fotográfico Un siglo de vida en Medellín .................................................... 31

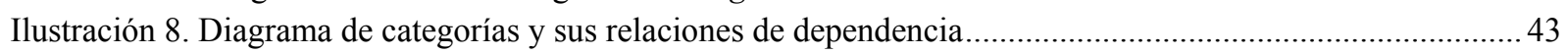

Ilustración 9. Matriz de la configuración del paisaje urbano. Eje cronológico y eje tipológico ............................... 48

Ilustración 10. Mosaico de imágenes del borde configurado en 1890 y revisado en la actualidad ........................ 49

Ilustración 11. Matriz del borde urbano consolidado entre 1870 y 1890 ............................................................5 54 
Ilustración 12. Localización de los elementos iconográficos del paisaje urbano de 1870-1890 y sus principales rasgos.

Ilustración 13. Localización de los elementos iconográficos del paisaje urbano de 1890-1910 y sus principales rasgos.

Ilustración 14. Localización de los elementos iconográficos del paisaje urbano de 1910-1925 y sus principales

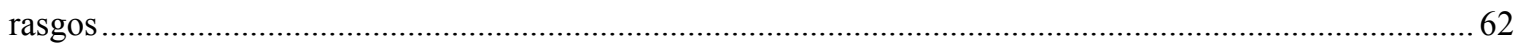

Ilustración 15. Los primeros barrios construidos en las áreas de expansión del nororiente de Medellín ................ 64

Ilustración 16. Plano del proyecto de la avenida (oriental) que irrumpe sobre el núcleo central de Medellín ........70

Ilustración 17. Localización de los elementos iconográficos del paisaje urbano de 1925-1940 y sus principales

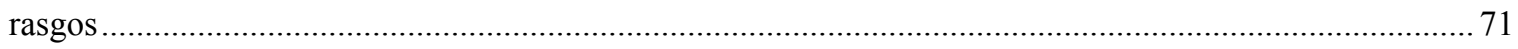

Ilustración 18. Localización de los elementos iconográficos del paisaje urbano de 1940-1950 y sus principales

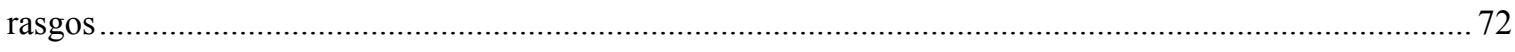

Ilustración 19. Localización de los elementos iconográficos del paisaje urbano de 1950-1970 y sus principales

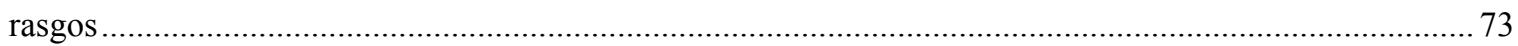

Ilustración 20. Localización de algunos elementos iconográficos del paisaje urbano de 1970-2010 y sus

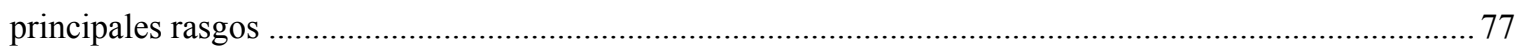

Ilustración 21. Identificación de los tipos de borde en la colisión de las placas urbanas de 1890,1910 y 1925, y de

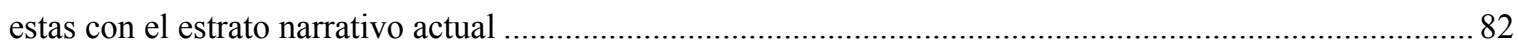

Ilustración 22. Identificación de los tipos de borde en la colisión de las placas urbanas de 1925,1950 y 1970, y de

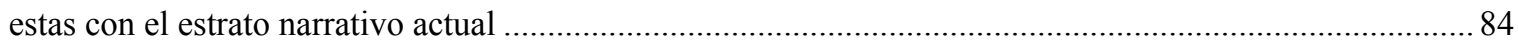

Ilustración 23. Las seis zonas administrativas del área urbana de Medellín.......................................................... 87

Ilustración 24. Estratos socioeconómicos predominantes por barrio en Medellín.................................................. 87

Ilustración 25. Unidades geomorfológicas del suelo de Medellín ................................................................. 87

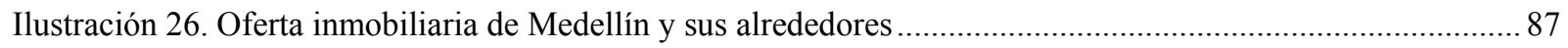

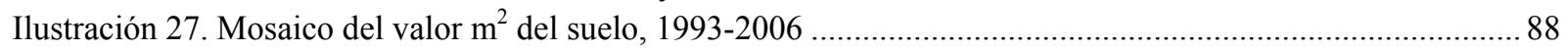

Ilustración 28. Identificación de los tipos de borde en la colisión de las placas urbanas de 1985, 1996 y 2006, y de

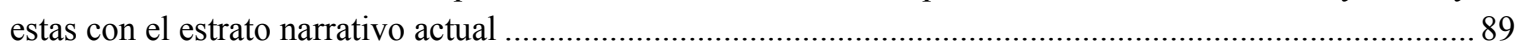

Ilustración 29. Incorporación de centros comerciales en áreas industriales en obsolescencia, cercanas a áreas

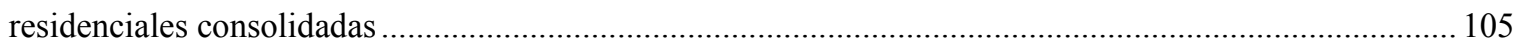

Ilustración 30. Valor de las transacciones inmobiliarias previas a la localización de centros comerciales, 2005106

Ilustración 31. Valor de las transacciones inmobiliarias después de la construcción de los centros comerciales,

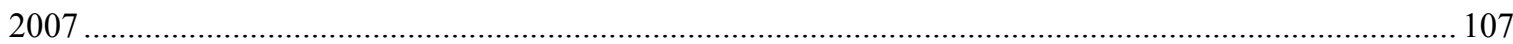

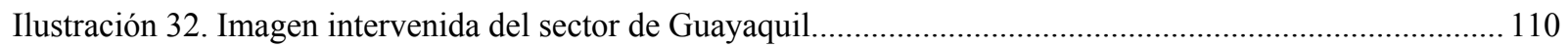

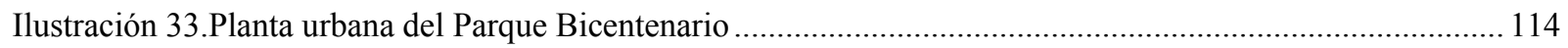

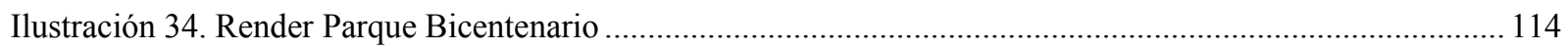

Ilustración 35. Mapa de compacidad absoluta del área urbana de Medellín y su relación con los bordes urbanos

Ilustración 36. Mapa de compacidad corregida del área urbana de Medellín y su relación con los bordes urbanos

Ilustración 37. Mapa de compacidad ponderada del área urbana de Medellín y su relación con los bordes urbanos

125

Ilustración 38. Gráficas que muestran las formas que sobre el espacio ejercen los bordes plegados en los subtipos: conglomerado, integrado, aglutinante, jerarquizado y alongado. ............................................................ 126

Ilustración 39. Gráficas que muestran las formas que sobre el espacio ejercen los bordes plegados en los subtipos: alongado y absorbente.

Ilustración 40. Gráficas que muestran las formas que sobre el espacio ejercen los bordes sedimentados en los

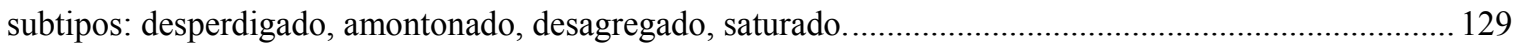

Ilustración 41. Cantidad de actividades jurídicas en primer piso y su relación con los tipos de borde ................. 131

Ilustración 42. Mapa de complejidad urbana según el porcentaje de actividades de proximidad ........................ 133 
Ilustración 43. Ocupación del uso residencial en relación a la zona núcleo de la ciudad.................................. 134

Ilustración 44. Densidad habitacional por barrio, 2009 .......................................................................... 135

Ilustración 45. Mapa axial. Análisis de integración de la accesibilidad vehicular ........................................... 138

Ilustración 46. Mapa axial. Análisis de integración de la accesibilidad peatonal............................................ 139

Ilustración 47. Registro fotográfico del recorrido por el paisaje urbano contemporáneo de Medellín a través de los

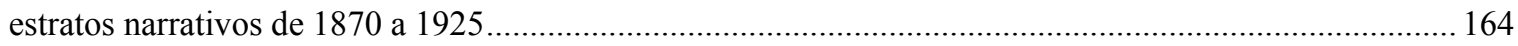

Ilustración 48. Registro fotográfico del recorrido por el paisaje urbano contemporáneo de Medellín a través de los

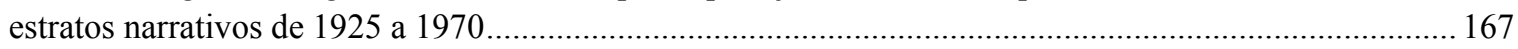

Ilustración 49. Registro fotográfico del recorrido por el paisaje urbano contemporáneo de Medellín a través de los

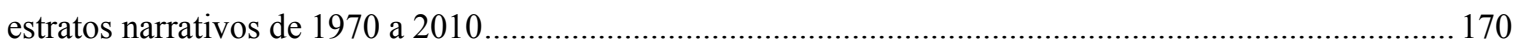

\section{ÍNDICE DE FOTOS}

Foto 1. Lote adquirido por Thyrel Moore, ciudadano extranjero e inversionista de la minería en Colombia que inicia el proceso de especulación urbana

Foto 2. Plaza Mayor heredada de la colonia. A finales del siglo XIX transformada en parque burgués y

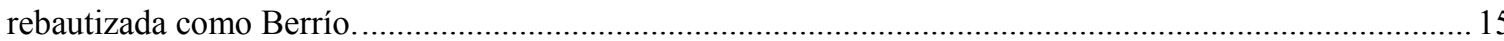

Foto 3. Parque Bolívar. Primer parque burgués construido en Medellín a finales del siglo XIX .......................... 16

Foto 4 y Foto 5. Surgimiento del edificio religioso monumental en el paisaje urbano de Medellín ..................... 17

Foto 6. Plaza de Mercado de Guayaquil. Localizada al sur del centro colonial de Medellín .............................. 18

Foto 7. Estación Ferrocarril de Antioquia. Sector de Guayaquil .................................................................... 19

Foto 8. Paisaje urbano caracterizado por una alta densidad constructiva de edificios en altura y por una baja

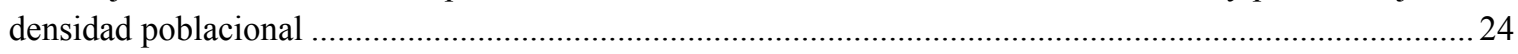

Foto 9. Transformación de la plaza mayor en el parque Berrío.................................................................58

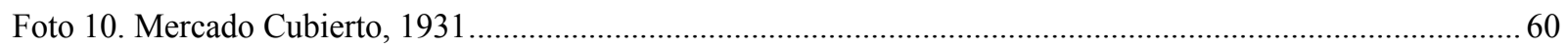

Foto 11. Alrededores de la plaza cubierta de mercado, sector Guayaquil, 1920s........................................60

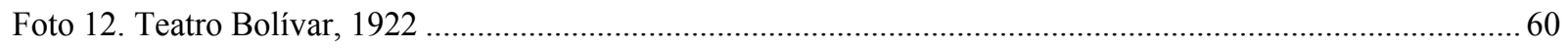

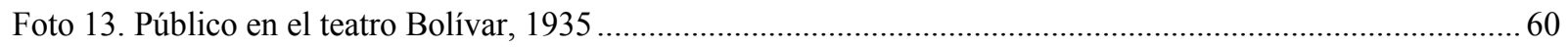

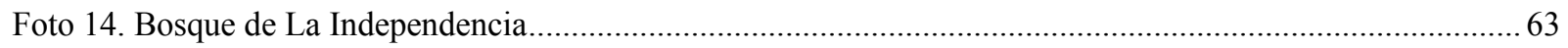

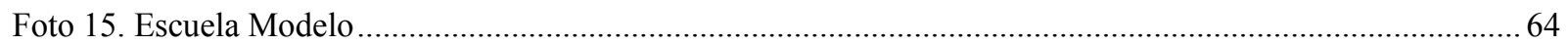

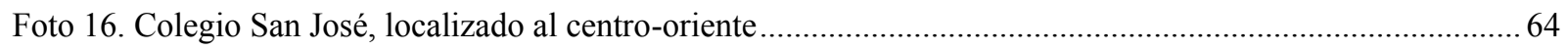

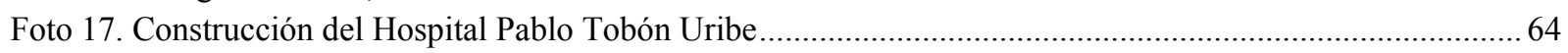

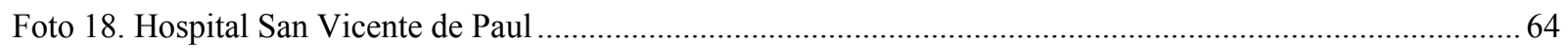

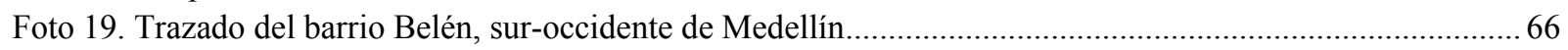

Foto 20. Trazado del barrio Laureles, centro-occidente de Medellín .............................................................66

Foto 21. Paseo de la calle Junín. Pasarela en la que se moldea la idea de la dama y el caballero burgués............. 67

Foto 22. Man chatting with woman standing in window. Medellín ..............................................................67

Foto 23. Habitantes de la calle junto a una vitrina comercial. Centro de Medellín ............................................67

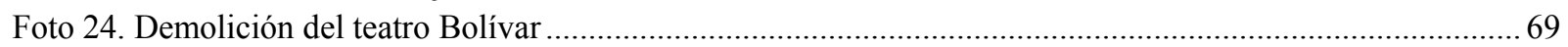

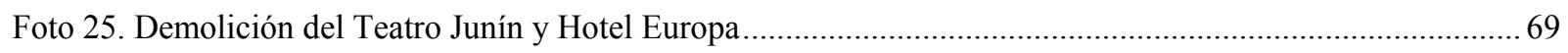

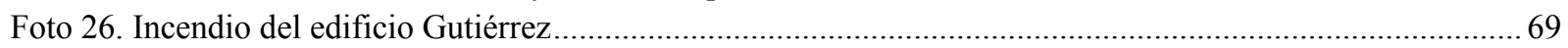

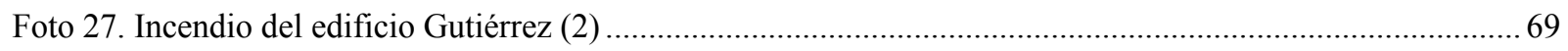

Foto 28. Demoliciones en la calle unión para dar paso a la avenida oriental ...................................................70

Foto 29. Niños pintando las culatas (muros ciegos) que dejo la apertura de la avenida oriental..........................70

Foto 30. Niños jugando al microfútbol en placa polideportiva ................................................................. 76

Foto 31. Plaza de mercado cubierta y Estación Central del Ferrocarril, 1959 ................................................92 
Foto 32. Edificios administrativos en antiguo sector de ferrocarriles, 1975 ................................................. 92

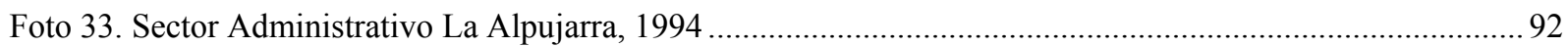

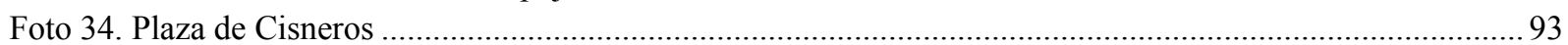

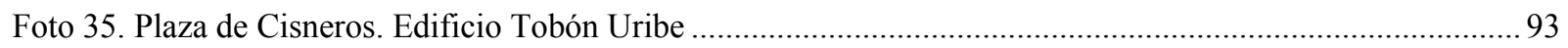

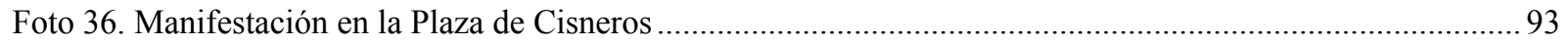

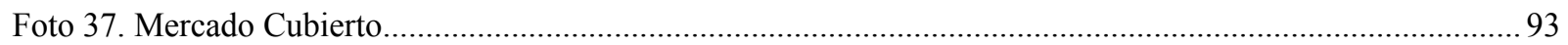

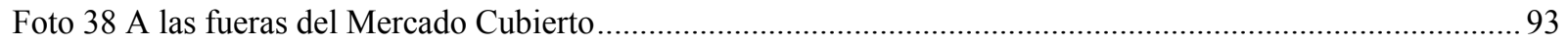

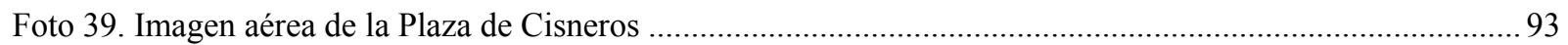

Foto 40. Pasaje Sucre demolido en enero de 2003 en aparente marco ilegal ....................................................... 94

Foto 41. Biblioteca EPM y La Plaza de La Luz sustituyendo el pasaje Sucre y la Plaza de Cisneros ...................94

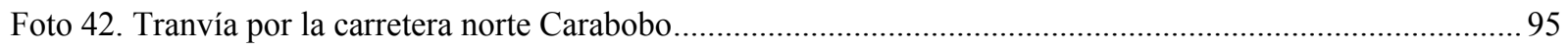

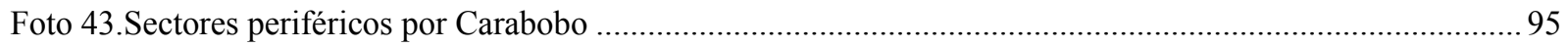

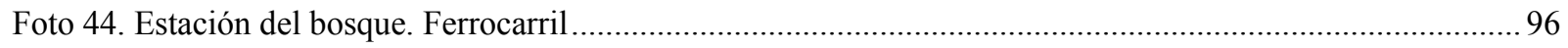

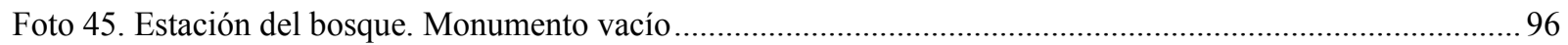

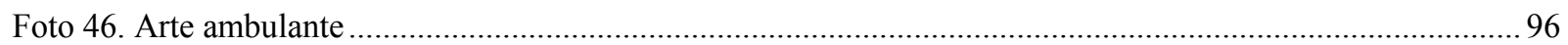

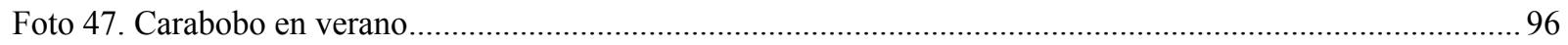

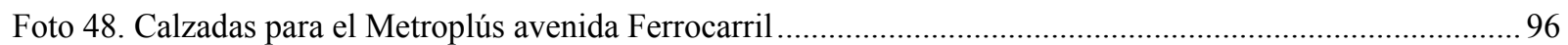

Foto 49. Calzada en construcción del Metroplús por el barrio El Chagualo ......................................................... 96

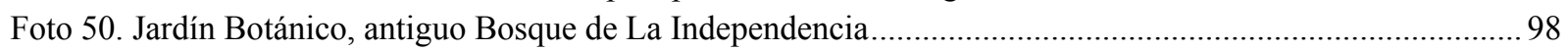

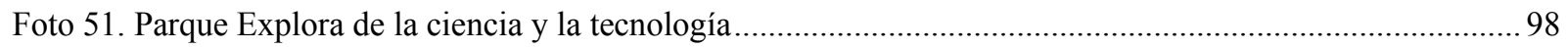

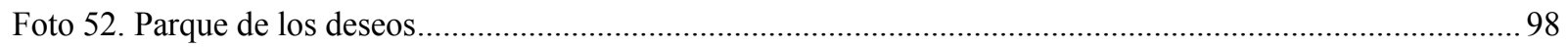

Foto 53. Intervenciones al norte del núcleo de la ciudad.............................................................................. 98

Foto 54. Aerofotografía de la centralidad de San Javier, comuna 13, Medellín en el 2004 ............................... 100

Foto 55. Aerofotografía de la centralidad de San Javier, comuna 13, Medellín en el 2012 .............................. 100

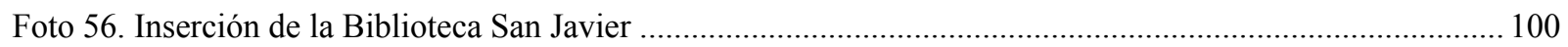

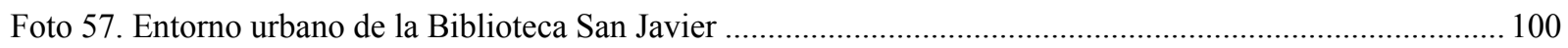

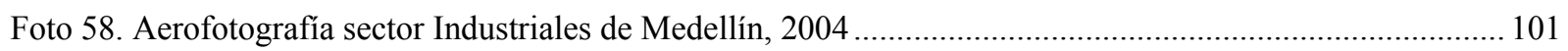

Foto 59. Aerofotografía sector Industriales. Proceso de transformación, 2008 ................................................... 101

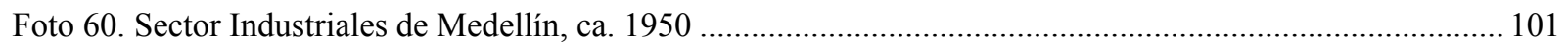

Foto 61. Taller industrial reciclado para albergar el Museo de Arte Moderno de Medellín................................. 101

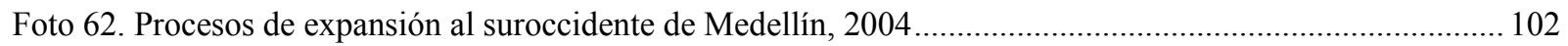

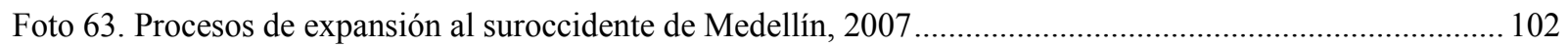

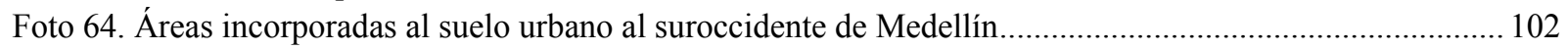

Foto 65. Morfologías irregulares y cerradas como propuestas de expansión. Suroccidente ................................. 102

Foto 66. Procesos de expansión al centro occidente de Medellín, 2004 .......................................................... 103

Foto 67. Procesos de expansión al centro occidente de Medellín, 2007 .......................................................... 103

Foto 68. Proceso de expansión urbana en el barrio Alto de Calasanz, centro occidente ...................................... 103

Foto 69. Proceso de expansión urbana en el sector Pajarito, centro occidente ..................................................... 103

Foto 70. Sector industrial al centro occidente en estado de obsolescencia, 2004 ............................................ 108

Foto 71. Centro comercial al centro occidente en lugar de industria que abandona, 2007 .................................. 108

Foto 72. Centro comercial Los Molinos. Centro occidente de la ciudad............................................................ 108

Foto 73. Centro comercial Premium Plaza. Cercano al centro tradicional .......................................................... 108

Foto 74. Zona industrial de Medellín cercana al centro tradicional, 2004 ....................................................... 108

Foto 75. Transformación de zona industrial cercana al centro tradicional, 2007 ............................................. 108

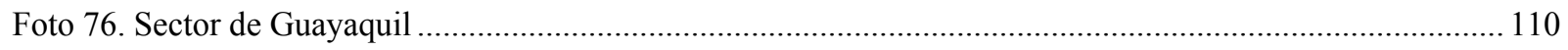

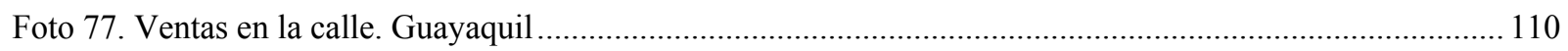

Foto 78. Desde la Plaza de Cisneros mirando al interior de Guayaquil a principios de los 80s ........................ 110

Foto 79. Monumento al ingeniero Cisneros también en el exilio. Interior de estación de ferrocarril restaurada . 111

Foto 80. Entorno actual de la Plaza de la Luz, antigua Plaza Cisneros ............................................................ 111 
Foto 81. Coltejer (Colombiana de Tejidos S.A) localizada en el sector de La Toma.

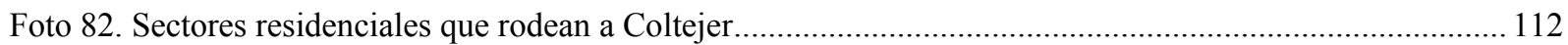

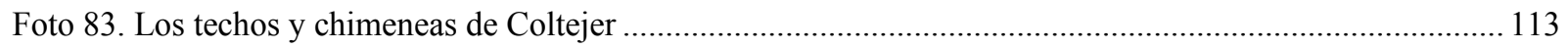

Foto 84. Fachadas y chimeneas de Coltejer........................................................................................... 113

Foto 85. Viviendas cercanas a la fábrica de Coltejer............................................................................... 113

Foto 86. Sector de La Toma. Barrio del centro- occidente de Medellín ........................................................ 113

Foto 87. Demoliciones para la construcción del Parque Bicentenario ............................................................ 113

Foto 88. Construcción de puente sobre la quebrada Santa Elena (Parque Bicentenario) para dar continuidad a la

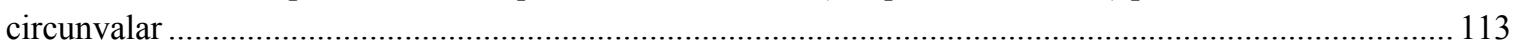

Foto 89. Transformación sobre las márgenes de la quebrada Santa Elena. Parque Bicentenario....................... 114

Foto 90. Pantalla de agua. Parque Bicentenario .......................................................................................... 114

Foto 91. Periferia del núcleo de Medellín. Avenida Primero de Mayo (quebrada Santa Elena) - Río Medellín,

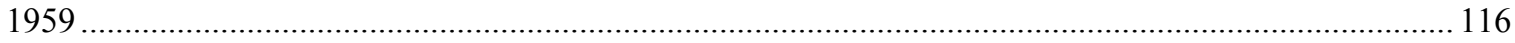

Foto 92. Periferia del núcleo de Medellín. Avenida Primero de Mayo (quebrada Santa Elena) - Río Medellín, 1975

Foto 93. Periferia del núcleo de Medellín. Avenida Primero de Mayo (quebrada Santa Elena) - Río Medellín,

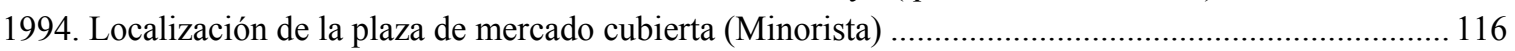

Foto 94. Antigua Estación Villa del sistema ferroviario .............................................................................. 117

Foto 95. La Plaza de Mercado Cubierta o Plaza Minorista ............................................................................. 117

Foto 96. Comercio informal alrededor de la Plaza Minorista..................................................................... 117

Foto 97. Almacén de baratijas, calle La Paz, cerca a la Plaza Minorista......................................................... 117

Foto 98. Movimientos alrededor de la Plaza Minorista........................................................................... 117

Foto 99. Movimientos bruscos de exiliados urbanos atravesando vías rápidas .............................................. 117

Foto 100. Proceso de expansión en el centro-oriente de la ciudad, 2004 ...................................................... 118

Foto 101. Proceso de expansión en el centro- oriente de la ciudad, 2008 ...................................................... 118

Foto 102. Proceso de redensificación en el barrio Belén Rincón, suroccidente (1).......................................... 118

Foto 103. Proceso de redensificación en el barrio Belén Rincón, suroccidente (2)......................................... 118

\section{ÍNDICE DE TABLAS}

Tabla 1. Relación de la expansión del suelo urbano de Medellín desde 1890 al 2010

\section{ÍNDICE DE MAPAS}

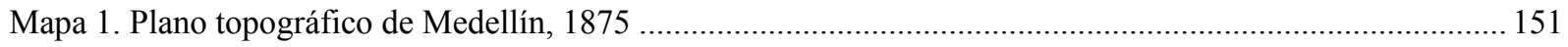

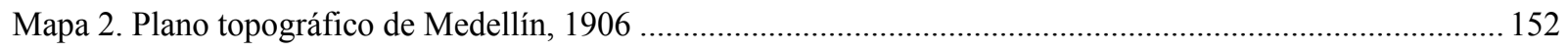

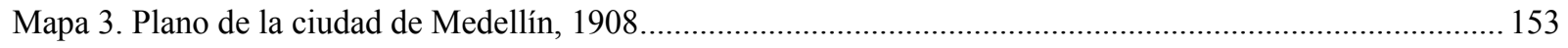

Mapa 4. Croquis del distrito de Medellín, 1929 ....................................................................................... 154

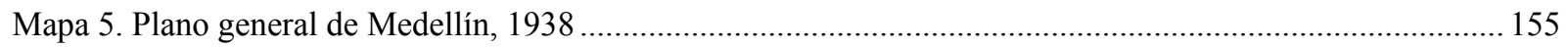

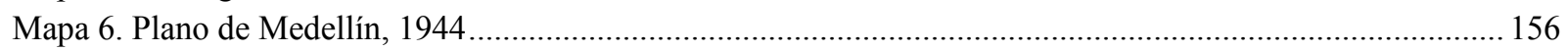

Mapa 7. Plano de "Medellín Futuro", 1913 .................................................................................................... 157

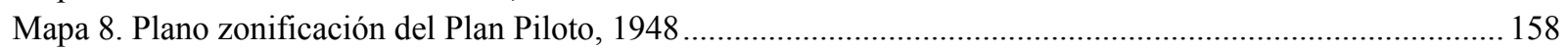

Mapa 9. Estudio de la forma urbana de Medellín, 1948 .............................................................................. 159

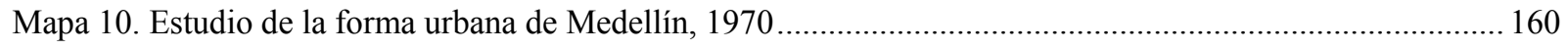

Mapa 11. Estudio de la forma urbana de Medellín, 1985 ........................................................................... 161

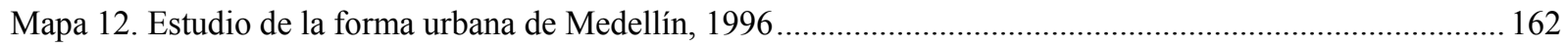

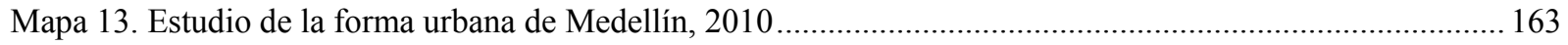




\section{NOTA DE AGRADECIMIENTO}

La presentación de esta investigación se debe en gran medida al aporte generoso de varias personas.

Quiero agradecer a las autoridades de la maestría de Paisaje, Medio ambiente y Ciudad de la Universidad Nacional de La Plata, por brindar la oportunidad a estudiantes extranjeros, como es mi caso, para participar en un debate abierto sobre los temas que en la actualidad se ciñen sobre esa triada de conceptos que dan por nombre al programa de posgrado. Tanto profesores como estudiantes de diferentes disciplinas y nacionalidades, encontramos en la maestría un espacio de reflexión, en el cual germinan ideas como las desarrolladas en este documento, en el cual, el autor reconoce retomar muchos argumentos expuestos por compañeros-colegas y docentes de la maestría.

Agradecimientos a los profesores Bethoven Zuleta y Alberto Pérez, quienes orientaron el desarrollo de esta investigación, dedicando parte de su valioso tiempo para leer, sugerir, pero sobre todo para conversar. A Bethoven, mis agradecimientos especiales por haberme hecho sentir tan acompañado en este proceso investigativo y por sus exigencias para que mantuviera el ritmo y la continuidad que requieren los compromisos académicos. A Alberto, mi gratitud por haber alentado varias inquietudes que motivaron el desarrollo de este trabajo, y también por mantener el contacto a pesar de la distancia.

Tengo también una deuda con mi amiga Bibiana Patiño, quien me prestó su asesoría y apoyo para la elaboración de los mapas con los cuales analizo el proceso de crecimiento y expansión de la ciudad de Medellín. Fueron muchas las horas que dedicó a mis solicitudes para obtener un material que aporta mucho a la comprensión de la metodología propuesta en esta investigación.

También quiero agradecer a familiares y amigos por entender que al estar involucrado en la escritura de este trabajo, no pude dedicarles el tiempo que merecen. Especialmente a Mery, quien además de su comprensión me ofreció todo su apoyo moral, tan necesario para que lograra la culminación de este proyecto.

A todos gracias y espero que en la lectura de este documento encuentren algunas respuestas que han venido formulándose, y también, que les suscite muchas más preguntas de las que hasta el momento nos hemos hecho juntos en torno al paisaje, el medio ambiente y la ciudad. 


\section{INTRODUCCIÓN}

Esta investigación es presentada para optar al título de la maestría de Paisaje, medio ambiente y ciudad de la Facultad de Arquitectura y Urbanismo de la Universidad Nacional de La Plata.

La tesis, titulada "El paisaje de borde urbano: Trayectorias semióticas en los discursos de construcción de la ciudad de Medellín", desarrolla en cuatro capítulos un análisis interdisciplinario de carácter histórico sobre el proceso de transformación del paisaje, apoyado en la aplicación de una metodología narrativa que explica los códigos y las combinaciones de las imágenes que los ciudadanos, como actores de la ciudad, experimentan y viven en las acciones cotidianas y trayectorias que guían sus recorridos.

En el primer capítulo son abordados el planteamiento del problema, los antecedentes de la transformación del paisaje urbano de Medellín y el estado del arte documental y bibliográfico, en este último son retomados registros fotográficos y otros materiales disponibles caracterizados como fuentes secundarias, para realizar una relectura de las líneas dominantes, tendencias y cambios del proceso de crecimiento vertiginoso de esta ciudad en los últimos 130 años. El segundo capítulo se definen los referentes teóricos, la hipótesis y la metodología de la investigación, y son puestos a prueba del ejercicio de la crítica los conceptos valorados como pertinentes para tratar el tema que vertebra este trabajo académico. Con el mismo criterio son cooptados los autores consultados y que han venido aportando al debate que refiere este tema. También, en estos apartados se ilustran los instrumentos metodológicos que son empleados para el desarrollo de la investigación, tomando la cartografía y la fotografía histórica, como herramientas fundamentales para la aplicación de las teorías narrativas del paisaje.

El desarrollo de la investigación se aprecia en el tercer capítulo, en el cual las lecturas que facilitan los registros de la transformación del paisaje urbano de Medellín permiten reconocer los estratos narrativos que han configurado a la ciudad en un proceso histórico acotado desde el momento de su agitación urbana a finales del siglo XIX hasta llegar a la primera década del siglo XXI. El recorrido por el paisaje contemporáneo de Medellín permite verificar que los estratos narrativos mantienen comportamientos dinámicos debido a los movimientos de expansión y contracción de la ciudad, originando colisiones y rupturas, dando así al surgimiento de distintos tipos de borde urbano que requieren ser comprendidos a través de categorías que expliquen sus cualidades.

Los distintos tipos de borde urbano son confrontados a través de algunos índices sugeridos por las teorías de la sostenibilidad urbana para corroborar las características narrativas que configuran a cada uno de estos ambientes. En este acápite se hace especial énfasis en las condiciones que los diferentes tipos de borde urbano ofrecen a los ciudadanos para ejercer la rememoración, en definitiva develar las estructuras de memoria funcionales y formales, que condicionan la experiencia perceptiva de los ciudadanos que atraviesan constantemente las diferentes escenografías urbanas.

Y como colofón de esta investigación se presenta el mosaico de imágenes que sintetiza, en una lectura diacrónica, el proceso de transformación del paisaje urbano de Medellín, para plantear con base en éstas, las líneas de acción a ser consideradas en el debate académico para una gestión del cambio, ya que en el contexto colombiano no ha sido un tema suficientemente discutido. Esta es una de las principales pretensiones de esta investigación, aportar elementos que permitan orientar 
una política que se ocupe de la transformación del paisaje urbano, atendida por los desfases narrativos que expresan los bordes urbanos dentro de esa superficie discursiva que es la ciudad. 


\section{CAPÍTULO 1. EL PLANTEAMIENTO Y LOS ANTECEDENTES DEL PROBLEMA DE INVESTIGACIÓN}

La ciudad es un sistema de vínculos entre los hombres y el territorio que se establece y evoluciona en un proceso histórico (Arias, 2003); sus estructuras físicas quedan impresas de manera indeleble, es el caso de los registros de su crecimiento y transformación. Una caracterización del proceso histórico acontecido en el espacio urbano de Medellín, allanaría el camino para descubrir la narrativa del paisaje urbano, guardado en la relación de sus componentes semióticos. Esto contribuiría a la identificación de los sistemas de mosaicos de territorio (Lynch, 1992), que son atravesados cotidianamente por los ciudadanos, y requieren ser comprendidos para una gestión del paisaje contemporáneo.

La ciudad es un sistema de códigos, estructurados de múltiples formas y combinaciones; en este sentido el paisaje urbano es una narración. Por lo tanto, éste puede ser leído por los ciudadanos para facilitar su orientación, recrear su memoria y disponer de diversas rutinas o itinerarios que dan sentido a sus trayectorias. Muchos de esos códigos que son leídos, algunos de ellos descifrables, son abiertos y explícitos (las señales de tránsito, por ejemplo) y otros obtienen su significado más allá de su valor, según sea su realidad contextual. (Arias, 2003).

Es necesario repensar el proceso de configuración del paisaje urbano, asumiendo este como producto de la expansión de la ciudad sobre el territorio que la acoge; como derivación también de movimientos de contracción que redefinen su espacio central, escenario de sus más influyentes representaciones. Reconocer las etapas de evolución y de crecimiento del fenómeno urbano de Medellín, desde el momento en que el espacio urbano sufrió una excitación hasta ahora incesante, permite identificar las diferentes capas de registro en las que la ciudad añade sucesivos elementos de significado, que a su vez se constituyen en mecanismos de lectura.

Narrar la ciudad de Medellín, en tanto el proceso de expansión ocurrido en los últimos 130 años, es restituir la organización formal del paisaje asumido como relato a través de la experiencia vivida por los ciudadanos, en una especie de deslaminado en donde la arquitectura aparece como el elemento que atraviesa el discurso urbano, en el que a su vez la ciudad atraviesa el discurso arquitectónico. ${ }^{1}$ La ciudad comprendida como una superficie discursiva revela la confrontación entre la lectura de la arquitectura y la escritura urbana: “(...) un espacio en el que la ciudad resiste al deseo de la arquitectura de transformarla y en el que la arquitectura insiste en su transformación" (Ramos, 2004: 166).

Una ciudad confronta, en el mismo espacio, épocas diferentes, ofreciendo a la mirada la historia sedimentada de los gustos y de las formas culturales. La ciudad se entrega, a la vez, para ser vista y ser leída.

En la ciudad (...) uno puede sentirse extraño en ella, errante, perdido, mientras que sus espacios públicos, sus plazas bien rotuladas invitan a las conmemoraciones y a las concentraciones ritualizadas (Ricoeur, 2008:194).

\footnotetext{
${ }^{1}$ Ángel Martín Ramos y Francoise Choay plantean este tipo de conceptos en su libro Lo urbano en 20 autores contemporáneos (ver referencias bibliográficas).
} 
En ese proceso de expansión y crecimiento de la ciudad se pueden reconocer estratos urbanos que fueron agregándose al espacio, determinando las transformaciones del paisaje; y la red simbólica entretejida a la lectura y la orientación que los ciudadanos experimentan cotidianamente. Estos estratos urbanos se estructuran a partir de vectores que dirigen su crecimiento, y transmiten a su vez la información nemotécnica heredada de la ciudad en su trayectoria, especialmente codificados por las ideologías prevalecientes en cada uno de los movimientos expansivos de la ciudad.

Los estratos narrativos que configuran el sustrato de la ciudad no se mantienen inmóviles o estáticos, al contrario, adquieren dinamismo al pretender constituirse en "máquinas de colonización" del espacio urbano, más allá de las fronteras que delimitan a cada uno. Estos movimientos de expansión o contracción de los estratos narrativos por sus traslapamientos, solapamientos, imbricaciones y rupturas dan lugar a la aparición de distintos tipos de bordes urbanos. Esta situación transforma constantemente el repertorio de relatos que produce el paisaje urbano, y desata un amplio juego de imágenes que requieren ser recategorizadas para su comprensión.

De esta situación apreciada en la configuración del paisaje urbano surgen varios interrogantes, que se enuncian como guías de una investigación que pretende desentrañar las lógicas del paisaje desde una estrategia de lectura, en donde la narrativa coloque al borde urbano como protagonista de las derivas y los cambios en la producción de imágenes (relatos del paisaje):

¿Cuáles han sido los distintos tipos de borde que se han configurado en el proceso de expansión de la ciudad de Medellín?

¿Es acaso el borde urbano una categoría de análisis que se acerca o supera conceptos como el límite topográfico, el límite administrativo o jurisdiccional?

¿Cuáles han sido los sentidos o las ideas que han venido transmitiendo los distintos tipos de borde en el crecimiento de la ciudad?

¿Es posible mostrar el cambio, la continuidad de ritmos, así como identificar los lugares de ruptura del paisaje urbano a través del relato que nos indican los bordes urbanos en la ciudad?

¿El borde urbano asume distintas categorías o formas de materialización de carácter funcional o figurativo, configurando moldes que determinan las experiencias del tiempo y el espacio en la ciudad?

¿Cuál es el motor que transforma ese relato simbólico en la cultura urbana?

¿Es posible una mirada hacia el paisaje urbano a través del borde urbano, que como vector, permita vislumbrar las tendencias que este sigue y así formular las bases de una gestión del paisaje urbano? 


\title{
1.1 El borde urbano en Medellín. Registro o antecedentes de una ciudad que se transforma
}

La explosión de la actividad urbana de Medellín se da a finales del siglo XIX entre las décadas del setenta y del ochenta, como coinciden varios autores ${ }^{2}$ estudiosos de la historia urbana de esta ciudad. A partir de dicho momento comienza a darse un tránsito entre un paisaje urbano pueblerino a un paisaje urbano burgués, que en parte abandona una herencia colonial española y emprende un proceso de apertura de influencias diversas, para que en pocos años, se configure una metrópoli urbana, construida por múltiples actores y fuerzas: el provinciano, la élite burguesa, las bonanzas de capital de la economía de exportación, los técnicos planificadores de la ciudad, los desplazados provenientes del campo, segmentos y estratos sociales emergentes articulados al narcotráfico; en fin, actores que dejan su impronta por un deseo de ciudad en el que quisieron vivir.

\subsubsection{Del paisaje pueblerino a la incorporación de elementos simbólicos detonadores de la expansión urbana. Medellín, 1870-1925}

La villa de La Candelaria o de Aná sólo fue reconocida, hasta 1776, como ciudad por el Consejo de Indias, otorgándole un nombre nuevo, Medellín, ratificada en 1826, ya en días de la República, como la capital de la provincia de Antioquia. Durante gran parte del siglo XIX transcurre con una dinámica más cercana a la de una villa colonial que a la de una ciudad republicana.

\begin{abstract}
Con la extinción del régimen político de La Colonia, no concluye "lo colonial" en la estética urbana; vuelto tradición, perdura tanto en las mentes de los seres como en sus obras: en la sicología, las costumbres y la cultura. Lo anterior se verifica con la persistencia, durante todo el siglo XIX, de las tradiciones urbanísticas y de los patrones arquitectónicos heredados del colonialismo hispánico. De tal manera que después de la Independencia, y mientras en el seno de la sociedad se van gestando lentamente las condiciones exigidas para los cambios territoriales, urbanísticos y arquitectónicos, los modelos espaciales coloniales conservan su vigencia y se mantienen intactos; desaparecido su soporte económico y social, derrumbada su legitimación política, subsiste su ideología y siguen reproduciéndose mecánicamente durante casi un siglo, aunque en forma un tanto arcaica (Aprile-Gniset, 1997: 58).
\end{abstract}

Aún a pesar de la ahincada tradición colonial, la insistencia de una élite ilustrada logra aproximadamente desde 1870 que la antigua villa inicie un proceso de tránsito hacia una ciudad burguesa (González, 2007). El emplazamiento de las nuevas industrias, así como de los primeros centros de educación técnica y tecnológica, constituyeron los principales detonantes de la transformación física de la ciudad y de la mentalidad colectiva hacia los asuntos públicos, sentando las bases de un proyecto ciudadano.

\footnotetext{
${ }^{2}$ Vale la pena destacar los estudios realizados por María Teresa Uribe, Fabio Botero, Roberto Luis Jaramillo, Verónica Perfetti y Luis Fernando González sobre la historia urbana de Medellín.
} 
La altísima renta que usufructuaban quienes se dedicaban a la minería en la región ${ }^{3}$ contribuyó a la transformación incipiente de la ciudad, franqueada por el ritmo de acumulación embrionaria de riqueza y por la constitución de élites de comerciantes y familias ricas que con su apetito especulativo sobre suelos rústicos, incorporan extensas áreas al perímetro urbano.

Foto 1. Lote adquirido por Thyrel Moore, ciudadano extranjero e inversionista de la minería en Colombia que inicia el proceso de especulación urbana

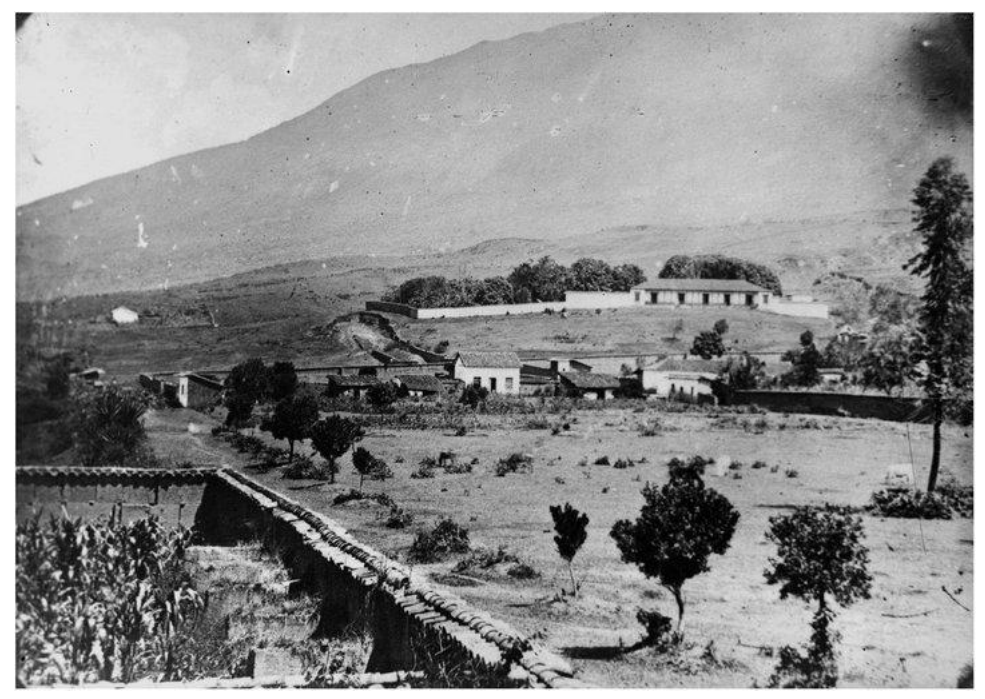

Fuente: Paulo Emilio Restrepo, ca. 1875

\footnotetext{
3 "A pesar del carácter letárgico de la ciudad, antes señalado, el panorama hasta aquí esbozado del atraco generalizado contra las tierras rurales se completa a la vuelta del siglo con una ofensiva de la especulación urbana en algunas ciudades. Más tarde aquí, más temprano acá, el asalto contra las tierras agrícolas y la reconstrucción del latifundio agrario producen las condiciones económicas y las riquezas que luego favorecen las inversiones en ciertos centros. Los mismos comerciantes importadores-exportadores que acumulan ganancias con la economía primaria de exportación, adquieren capitales para invertir en propiedad urbana y convertirse en especuladores y rentistas urbanos. Se produce nuevamente una alianza de intereses económicos e ideológicos; volvemos a encontrar un pacto entre la especulación monetaria y la ideología del progreso, asociada ésta con la teoría del libre cambio y algunos postulados altruistas sacados del ideario de la masonería. Correlativamente, en una ciudad u otra, pero en forma diacrónica y de manera desigual, surge o toma impulso el concepto de especulación raíz y de renta urbana” (Aprile-Gniset, 1997: 51).
} 
La expansión del viejo casco urbano a finales del siglo XIX se da principalmente hacia el norte con promotores como Thyrel Moore, ${ }^{4}$ un británico propietario de importantes zonas mineras, quien forja el negocio inmobiliario cediendo parte de las tierras adquiridas en la ciudad, para construir el primer parque burgués y edificar una catedral, que por supuesto constituyeron los detonantes del crecimiento urbano de lo que va a ser denominado: Villa-Nueva.

\section{- La primera expansión urbana de Medellín y la incorporación de nuevos elementos simbólicos en el paisaje urbano. Medellín, 1890-1910}

A pesar de que en Medellín no se consolidó por completo la forma urbana reglamentada por las Leyes de Indias, con el trazado en damero más allá del entorno cercano de la plaza, hizo de ésta la principal referencia del escenario público. La plaza como estructurante urbano se implanta en el lugar de representación simbólica de las instituciones que gobernaban la vida y el ambiente público y privado, estructurando tres campos de la sociedad y la cultura: el civil, el militar y el religioso, hacia las cuales los habitantes hacían venia como signo de sometimiento y validan su reconocimiento como súbditos.

Mientras el parque como tipología del espacio urbano fue importado de la cultura anglosajona y francesa, para simbolizar la presencia de la naturaleza en la ciudad, introduce además el rito del paseo y del disfrute del pueblerino que para estos momentos ha sido transformado culturalmente en ciudadano pleno de derechos civiles.

Foto 2. Plaza Mayor heredada de la colonia. A finales del siglo XIX transformada en parque burgués y rebautizada como Berrío.

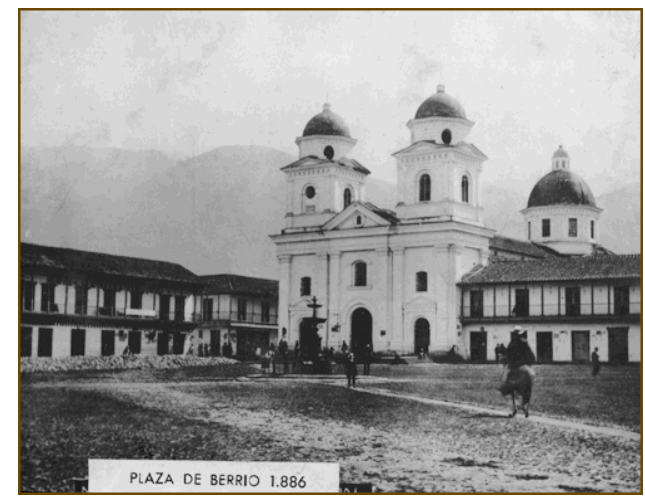

Fuente: Paulo Emilio Restrepo, ca. 1886

\footnotetext{
4 "En los años de 1920 la ciudad cuenta con dos centros distintos, pero articulados: progresando hacia el sur, los nuevos edificios comerciales de estilo 'neoclásico indiano' poco a poco van sustituyendo a las antiguas casonas de bahareque, entre la Plaza Mayor y el parque de Bolívar. Con un urbanismo promovido por un inglés, un parque 'a la francesa', faroles y rejas importadas de Europa, la arquitectura del italiano Crosti y de los franceses Carré y Lelarge, el nuevo centro de Medellín había roto con la dominación del legado español y se sometía al nuevo colonialismo. Era el primer paso hacia un exhibicionismo que alcanzaría durante la danza de los millones la máxima megalomanía, con trianones, casa egipcia, un castillo medieval con torres cubiertas en hojalata y la imprescindible casa del millón” (Aprile-Gniset, 1997:38).
} 
La plaza es un ambiente seco, sin elementos que obstruyan la vista de amplios panoramas; es un lugar en el que prima la escenografía brindada por los edificios circundantes en su área, que gozan del total protagonismo. En las ciudades latinoamericanas, como es el caso de Medellín, por aquel entonces, los elementos urbanos hacían lucir un trasfondo natural de gran vigor como son las cordilleras.

En los parques y el bosque urbano se representarían imágenes burguesas, replicando las figuras producidas un siglo atrás en Europa, donde los parques privados de la nobleza son incorporados al ámbito de lo público. El parque simbolizaba pues la conquista de derechos de los ahora ciudadanos obreros y el surgimiento de una nueva clase emergente que dinamiza y cohesiona la sociedad, la burguesía, y en su reverso complementario, los proletarios de las industrias y asalariados en las empresas comerciales y bancarias.

Foto 3. Parque Bolívar. Primer parque burgués construido en Medellín a finales del siglo XIX

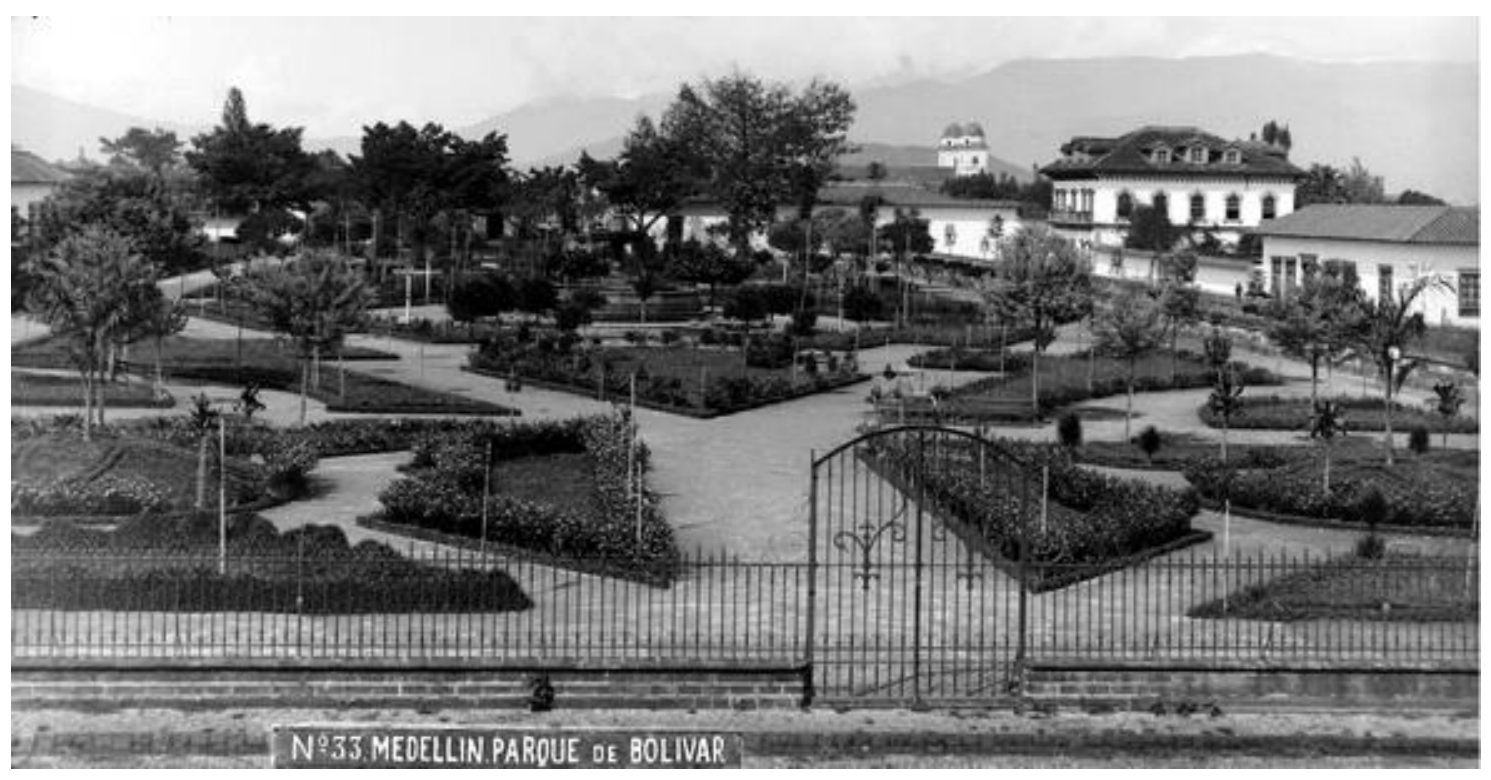

Fuente: Melitón Rodríguez, ca. 1900

Simultáneamente a la gesta del parque en el lugar público, la catedral fue otra incorporación edilicia que se suma a la serie de elementos que transforman la ciudad a finales del XIX. Ciertamente, el edificio público religioso venía desde la colonia; sin embargo, lo novedoso esta vez fue la escala de la intervención, en la medida que su erección en un paisaje hasta entonces dominado por casas chatas de uno y dos niveles, con calles estrechas y de carácter aún muy rural, hacen ver este edificio como una edificación de desproporción colosal. ${ }^{5}$

\footnotetext{
${ }^{5}$ Sobre la aparición de las grandes iglesias en la época de la república autores como Aprile-Gniset manifiestan su actitud crítica al anotar: “(...) Pero confundiendo quizá el exhibicionismo provocador con el prestigio, o asociando el gigantismo con la monumentalidad, la Iglesia de la República iba a sacrificar deliberadamente el buen gusto a la vulgaridad ostentosa y babilónica" (1997:94).
} 
Este patrón de expansión de lo urbano se repetirá en muchos de los posteriores barrios de gestores privados, quienes dejan una manzana vacía para el parque y un espacio reservado para la iglesia. ${ }^{6}$ Esto definitivamente marcó el paisaje de la ciudad, pues las altas torres de diversos estilos son sin duda referentes de los diferentes sectores que se van agregando a la estructura urbana, que a su vez se constituyen en faros de la moral católica, control social imperante de una sociedad aún atada a los rezagos de la cultura colonial.

Foto 4 y Foto 5. Surgimiento del edificio religioso monumental en el paisaje urbano de Medellín
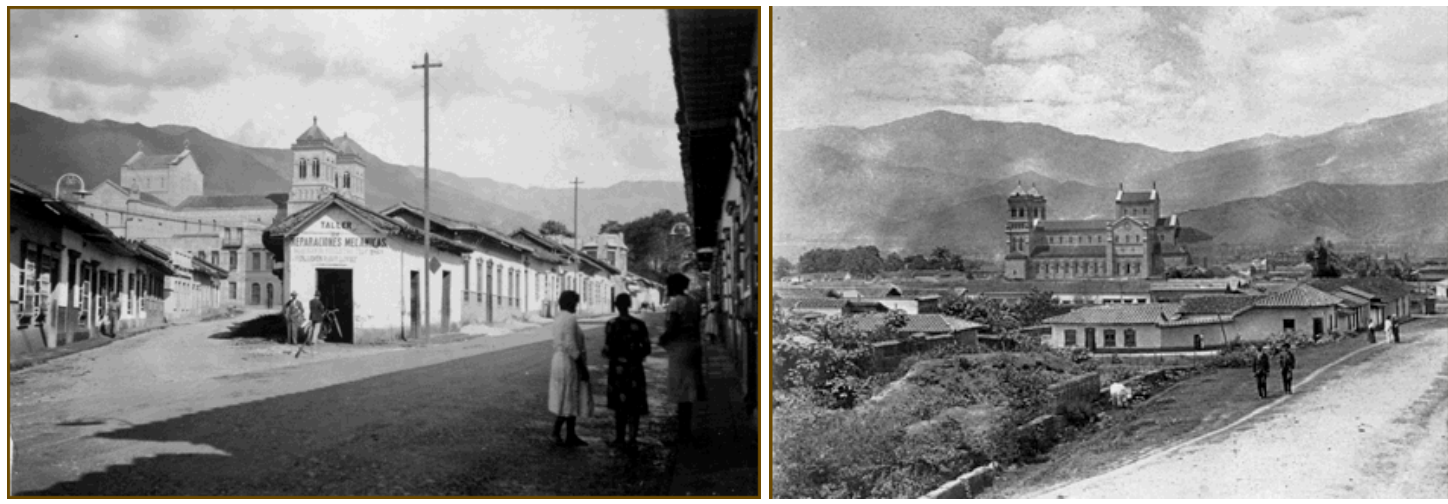

Fuente: Melitón Rodríguez, ca. 1910

La élite precursora de la transformación urbana trajo del viejo continente arquitectos europeos, y con ellos nuevas tecnologías y materiales para impulsar nuevos modelos que comenzaron a modificar no sólo los trazados urbanos y el lenguaje de la arquitectura, sino también los comportamientos colectivos, haciendo de la ciudad un lugar permanente de experimentación de materiales, formas, figuras, estilos y estrategias integradas al dinamismo económico.

\section{- La plaza de mercado cubierta y el ferrocarril. Detonadores de la expansión urbana y de nuevas pautas de comportamiento social. Medellín 1910-1925}

Si en las dos últimas décadas del siglo XIX el parque burgués y la colosal catedral instalan la impronta del paisaje urbano de Medellín, en los últimos años del mismo siglo y los primeros del XX será la plaza de mercado ${ }^{7}$ el proyecto urbano que detona la expansión de Medellín, emprendido ahora al oriente y al sur de la ciudad.

\footnotetext{
6 “(...)surgida de una reconquista ideológica provocadora y del Concordato, actuando como su instrumento político, la arquitectura religiosa gigantesca y ecléctica, desde finales del siglo XIX, expresa en forma diáfana un momento de las relaciones entre el Estado y el Vaticano: es arquitectura del Concordato y de su victoria, adecuada forma de un determinado contenido" (Aprile-Gniset, 1997:95).

7 "Socialmente, se observan el ascenso y el poder de los grandes negociantes dependientes del comercio con Inglaterra. Llegan a conformar en sus bancos, clubes y cámaras de comercio un bloque de poder económico y político, dominando la vida de las ciudades y plazas comerciales, desde fines del siglo XIX hasta bien entrado el XX. Indicadores de ello son el club, el teatro, la cámara de comercio y la plaza de mercado. Cristalizan la expresión simbólica y arquitectónica de la agremiación de individuos solidarizados por intereses y conscientes de que son integrantes de una clase, unida por sus disputas con otras" (Aprile-Gniset, 1997:95).
} 
La incrementada densidad de habitantes provenientes de distintos rincones del mundo rural de la provincia, y que hacían su tránsito a la condición de ciudadanos, es ahora el principal acicate de transformación del ambiente urbano. El paso de los tiempos sociales cerrados y estrechos a los tiempos dinámicos de la vida citadina vuelve insuficiente y agotado el lugar escénico. Las calles coloniales tornan estrecho el denso movimiento de los nuevos inquilinos; la apertura y demanda de los mercados exigen la especialización de la oferta comercial, ${ }^{8}$ lo cual modifica significativamente los usos del suelo ocupados por áreas residenciales envejecidas que son convertidas en reconocidos sectores y corredores de actividad múltiple.

Las viejas tipologías coloniales se evidencian obsoletas frente a la incesante dinámica urbana. La apariencia de la ciudad ahora tenía que ser otra, que correspondiera más al de la nueva ciudad burguesa, que la que mostraba aquella fruto del aislamiento geográfico al que estaba sumida, pues las infraestructuras de transporte como el ferrocarril le permitían ya mantener contactos más constantes con el mundo al que deseaba integrarse, intención ansiosa que aun en nuestros días continúa suscitando la transformación urbana para acceder al club de ciudades "marketing". 9

Foto 6. Plaza de Mercado de Guayaquil. Localizada al sur del centro colonial de Medellín

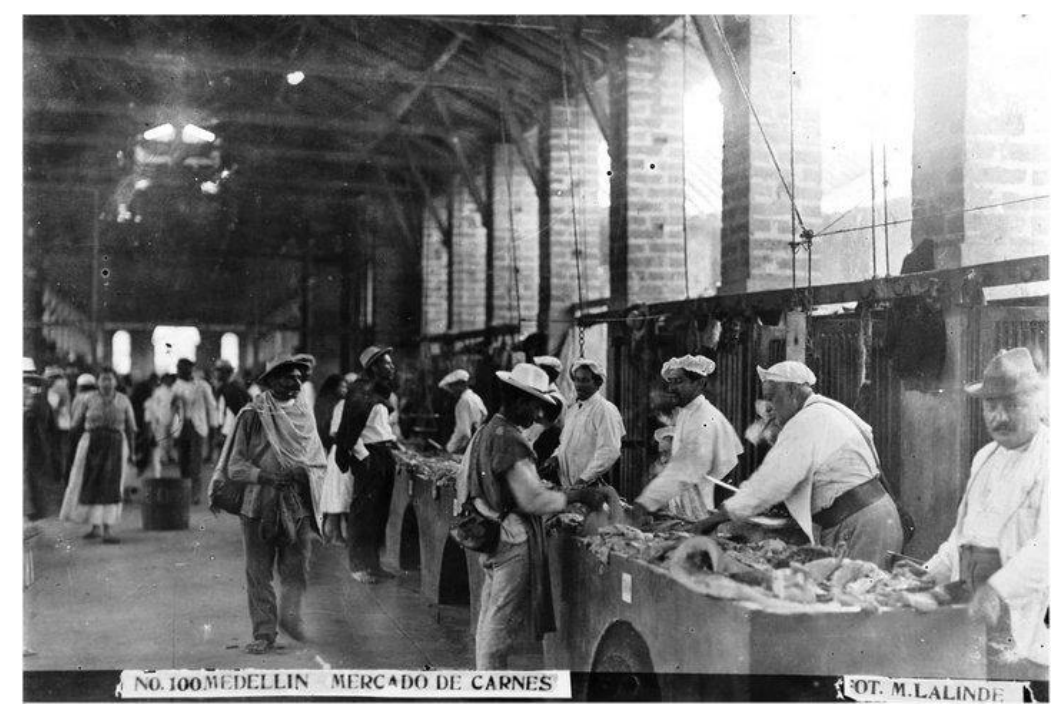

Fuente: Lalinde, ca. 1910

Es en las dos primeras décadas del siglo XX que la transformación del paisaje urbano alcanza niveles insospechados, comparados con sus etapas previas de crecimiento. Esto debido a las introducciones de orden tecnológico asociadas directamente a la construcción y a la movilidad inter e intraurbana. Las nuevas generaciones, hijas de la élite precursora, ahora muchos de ellos

\footnotetext{
${ }^{8}$ González (2007) destaca cómo la aparición de los almacenes especializados de calzado, sombreros, entre otros, son una evidencia de la compleja actividad urbana promovida por el nuevo ciudadano, empleado de las fábricas, las oficinas bancarias y de los mismos almacenes comerciales.

${ }^{9}$ En los últimos ocho años en Medellín se han realizado cuantiosas inversiones para consolidarse como sede de ferias internacionales de moda, y para albergar nuevos eventos de orden cultural, político y deportivo.
} 
profesionales de la Escuela de Minas, ${ }^{10}$ junto con quienes se formaron en el exterior y los profesionales extranjeros, comienzan a introducir poco a poco la modernidad. Primero con los edificios públicos, luego con sistemas de transporte urbano como el tren y luego el tranvía, así como la transformación de la tipología de vivienda, tanto para la amplia clase obrera como de la misma élite.

Foto 7. Estación Ferrocarril de Antioquia. Sector de Guayaquil

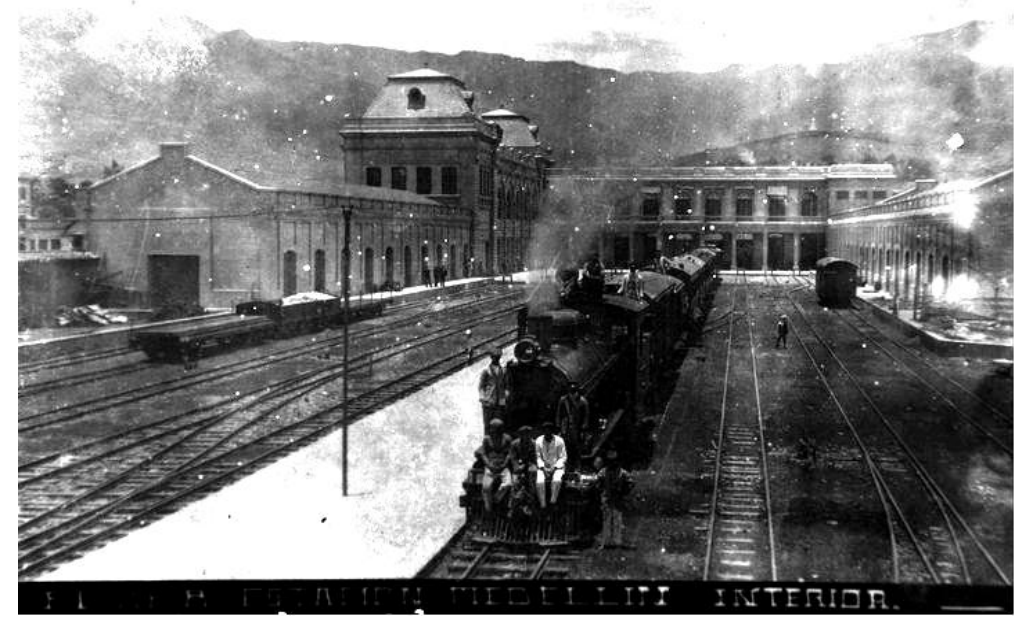

Fuente: Benjamín de la Calle, ca. 1910

Es posible desentrañar del proceso de crecimiento acaecido en la ciudad desde 1870 hasta 1920 dos posturas en el orden ideológico y político que determinaron en gran parte la transformación del paisaje urbano de Medellín. El primero está muy identificado con el pensamiento higienista o lo que algunos teóricos denominaron "fisiología de la ciudad", y el segundo desde un énfasis más funcional en el que la preocupación central es el sistema de movilidad de la ciudad.

La primera corriente estuvo impulsada especialmente por los médicos de la ciudad a quienes preocupaba el proceso de crecimiento demográfico, la expansión irracional y las posibles consecuencias que estas dos cosas juntas trajeran a la salud pública. Su batalla estuvo principalmente centrada en aspectos como la prohibición de actividades más propias de la ruralidad como lo cría de animales en sectores de configuración más urbana, la ampliación de las calles en el casco viejo y la construcción de acueductos y alcantarillados. Su influencia logró que el Concejo de Medellín exigiera la reglamentación de estos aspectos y los empréstitos requeridos para la consecución de las áreas y construcción de infraestructura para saneamiento.

${ }^{10}$ La Escuela Nacional de Minas se crea bajo la Ley 60 de 1886. Con sede principal en la ciudad de Medellín, pretende formar ingenieros aprovechando el alto potencial minero de la región de Antioquia, ya que hasta finales del siglo XIX era necesario traer profesionales extranjeros preparados en el tema. Los egresados de esta escuela de educación superior no sólo se dedicaron a la actividad minera, también participaron activamente en el sector de la construcción y en la creación de fábricas, especialmente metalúrgicas que tuvieron asiento en Medellín gracias a la llegada del ferrocarril. 
El arbolado urbano también fue una preocupación en este sentido; organizaciones sociales como la Sociedad de Mejoras Públicas y algunos personajes de la sociedad sirvieron como promotores de la siembra masiva en el paisaje urbano. ${ }^{11}$

La segunda corriente, como se anotó anteriormente, asociada más a un pensamiento funcional, tomó influencia a principios del siglo XX poniendo especial atención en ordenar el territorio urbano a partir de las calles donde el tránsito a motor se privilegió por encima del peatón, lineamiento que desde entonces ha permanecido en la planeación urbana de la ciudad de Medellín.

La extensión de las calles en la ciudad se constituyó en el detonante de la especulación inmobiliaria, a tal punto que, los mismos particulares tomaban iniciativa en la prolongación de las mismas para la venta de lotes. El sector público en muchos casos libró batallas infructuosas para que los intereses privados se sujetaran a las previsiones que los instrumentos de planificación habían determinado para aquel entonces como el caso del Plano Medellín Futuro. ${ }^{12}$

\subsubsection{El salto de la ciudad hacia el occidente y el inicio de un crecimiento desbordado. Medellín, 1925-1970}

Entre 1925 y 1940, aproximadamente, el perímetro de la ciudad de Medellín duplica su extensión gracias a la prolongación de las líneas del tranvía. Las empresas urbanizadoras que para este entonces ya eran numerosas promueven varios proyectos al norte, destacándose los barrios obreros de Manrique, Campo Valdés, Berlín y Aranjuez ${ }^{13}$.

También hacia el norte, tiene comienzo los primeros procesos de renovación urbana, en lo que en aquel entonces denominaban "Muñecones", ${ }^{14}$ detonados con la incorporación al paisaje urbano de novedosos componentes como "El Bosque de la Independencia" muy relacionado con la expansión de los barrios nombrados anteriormente, y el hospital San Vicente de Paúl, proyectado en un programa de renovación urbana.

El barrio Villanueva, de principios del siglo XX, genera a su vez un proceso de expansión emparentado con el proyecto inmobiliario de reubicación de la élite en el barrio Prado. Por su parte, al oriente de la ciudad, muy próximo a la plaza de mercado "La Placita de Flores" y el recién

\footnotetext{
${ }^{11}$ Fernando Botero (1996) destaca cómo la Sociedad de Mejoras Públicas de Medellín, creada en la última década del siglo XIX por una élite dirigente, insistió en la creación de un espíritu cívico, promoviendo campañas de diversa índole relacionadas a la ciudad, entre ellas la institución del día del árbol.

${ }^{12}$ Como lo anota Botero (1996) en este plano tenían interés algunos empresarios muy ligados al negocio de la propiedad raíz, aun así, fue el primer instrumento de planeación de la ciudad que pretendía tener una imagen global a la que debía ajustarse cualquier iniciativa particular. Desafortunadamente los ajustes que sufrió el plan, por los intereses de algunos pocos, terminó por desvirtuar muchos de sus planteamientos.

${ }^{13}$ Estos son los nombres que se le dieron a los primeros barrios obreros en Medellín, y que en la actualidad constituyen sectores residenciales de reconocida consolidación.

${ }^{14}$ Así se reconocía el sector cercano al cementerio de San Pedro (también conocido como cementerio "de los ricos"). Sus propietarios eran de una familia de apellido Muñoz. Los inquilinos de este lugar lo dedicaban entre varios usos a uno con especial predominio, casas de burdel y cantinas.
} 
erigido monumento al Cristo Salvador, se desarrollan los barrios Bomboná, Buenos Aires y El Salvador.

Ilustración 1. Crecimiento de la extensión urbana de Medellín entre 1870 y 1932

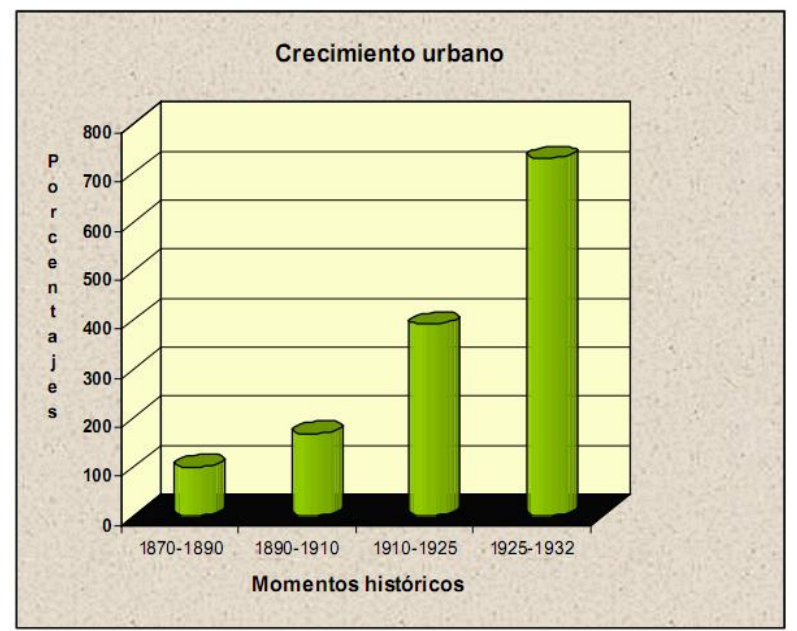

Fuente: González, 2007.

- El salto de la ciudad a la otra banda del río y el surgimiento de una nueva ciudad trazada bajo las influencias de movimientos de la época. Medellín 1940-1950

A partir de 1940 se consolida la estructuración y domesticación del occidente de la ciudad de Medellín, hasta entonces conocido como Otra Banda. En esta parte de la ciudad se desarrollaron amplios proyectos residenciales organizados en cooperativas de vivienda, destinados a las clases obreras. En el paisaje urbano aparecen amplias avenidas, arboladas, bulevares y renovados trazados, inspirados en las corrientes del urbanismo como el "Garden City" o "New Towns".

Barrios como Laureles y Bolivariana aún son un digno ejemplo de estos postulados del urbanismo cuyos atributos se han puesto en riesgo por los actuales procesos de densificación, tema que será abordado más adelante en el proceso investigativo, precisamente como una de las consecuencias en el traslape o solapamiento entre distintos tipos de borde urbano.

Entre las décadas del cuarenta y del cincuenta del siglo XX, el desarrollo de las áreas residenciales en el occidente de la ciudad va acompañado de la localización y adecuación de grandes equipamientos, en este caso de educación y deporte principalmente. La Universidad Pontificia Bolivariana y el Estadio Atanasio Girardot, por su misma dimensión, tratan de ajustar sus ofertas al tamaño alcanzado por la ciudad, e incluso de reservar suficientes áreas para la ampliación de sus infraestructuras. 
Ilustración 2. Artículo de la prensa nacional en 1953 relacionado a la expansión urbana del occidente de Medellín

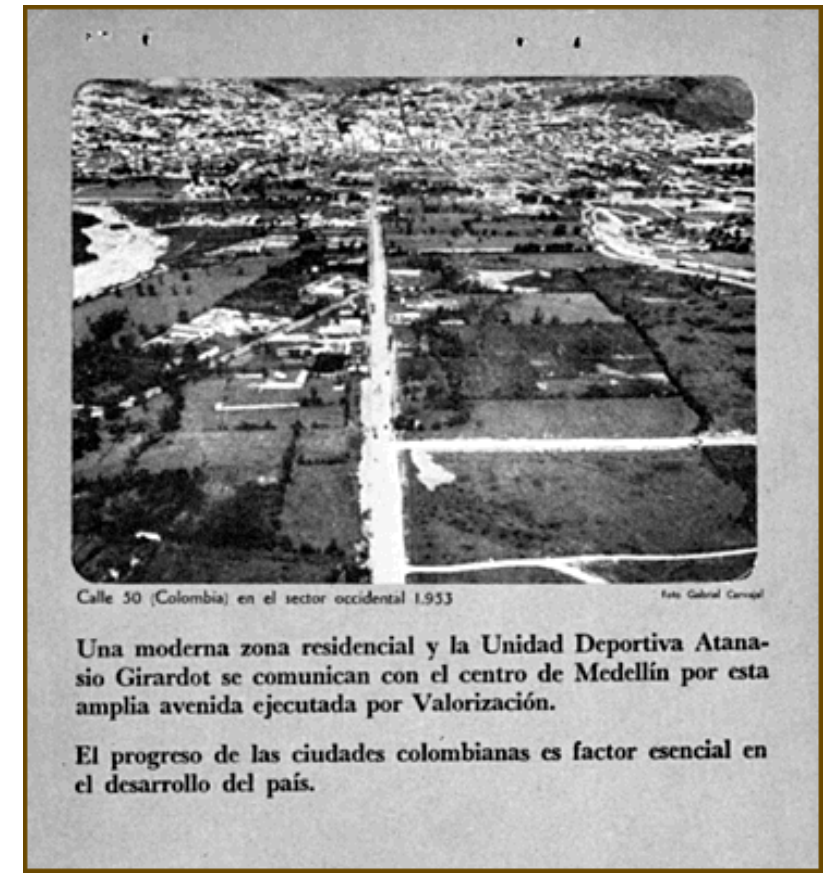

Fuente: Revista Progreso (Sociedad de Mejoras Públicas de Medellín), 1953.

\section{- Una ciudad compleja para su administración y para la percepción de sus ciudadanos. Medellín, 1950-1970}

En el período que comprende los años entre 1950 y 1970 la ciudad no sólo continúa su proceso expansivo sino que también comienza a modificar drásticamente su perfil urbano. Las áreas fragmentadas de la ciudad cuyos procesos de crecimiento fueron independientes ahora se entrelazan con la construcción de puentes que superan los obstáculos geográficos. La ciudad comienza a hacerse cada vez más compleja, y el ciudadano, para la lectura y orientación dentro de la misma, acude cada vez más a los elementos singulares que se destacan en el paisaje urbano.

El tranvía, ahora reemplazado por una red de buses, y el automóvil particular permiten el acceso a zonas que estaban reservadas por la especulación inmobiliaria desde décadas atrás, especialmente en el occidente de la ciudad. Las migraciones campesinas siguen en aumento y esa otra ciudad marginada ocupa cada vez más espacio; a la compleja planeación física se suma lo social con sus múltiples aristas.

La administración de la ciudad realiza tareas operativas y reglamentarias para aplicar las disposiciones del Plan Piloto. ${ }^{15}$ La ciudad empieza a ser vista y pensada en grandes globos o áreas con funciones específicas. Se comienzan a ejecutar acciones para transformar drásticamente áreas que tradicionalmente eran ocupadas para algunos usos específicos siendo reemplazados por otros.

\footnotetext{
${ }^{15}$ Desde 1948 la ciudad de Medellín contaba con un plan ajustado a los planteamientos del racionalismo moderno. Para tal efecto la administración municipal encargó a los arquitectos Wiener y Sert la formulación de un Plan Piloto, obedeciendo así a leyes del orden nacional que exigían el diseño de estos instrumentos para ciudades que superarán los 100.000 habitantes.
} 
La ciudad también se ocupa de recuperar amplias zonas para la recreación, no sólo para el habitante local sino para incentivar la actividad turística. El Cerro Nutibara y el Jardín Botánico, antes Bosque de la Independencia, son publicadas en postales de la ciudad.

\subsubsection{La ciudad producto de la máxima renta, de la segregación y de las pretensiones de internacionalización. Medellín, 1970-2010}

Entre 1970 y 1985 el fenómeno de la metropolización toma mayor fuerza, soportado especialmente en los proyectos viales ${ }^{16}$ que integraron las diez ciudades del Valle de Aburrá en una sola. Esto por supuesto deriva en efectos sobre la configuración de la forma urbana y en la percepción de la misma, cuando se aprecia que ya no existe rincón alguno en el valle, y en las estribaciones, que escape al proyecto de territorialización urbana.

En este período la construcción de viviendas fue una política agresiva, ${ }^{17}$ en la que se apreció el paso paulatino del compromiso y desarrollo de los proyectos de empresas del mismo Estado a la entrega completa de ésta al sector financiero, que ha sabido hacer de la misma un negocio lucrativo, en el que se desconocen los altos costos que la ciudad en últimas debe asumir. ${ }^{18}$

De las unidades residenciales con amplias zonas verdes y espacios públicos articulados a la ciudad y con unidades de habitación amplias y generosas, la ciudad ha pasado a modelos de urbanización cerrada y desarrollos lote a lote con la oferta de viviendas cada vez más reducidas en área y sin la suficiente dotación para el encuentro y la dispersión colectiva.

\section{- La consolidación de un modelo de segregación urbana. Medellín, 1985-2000}

Entre los años 1985 y 2000 las morfologías urbanas anteriormente descritas se consolidan como las predilectas para hacer ciudad, o mas bien, para acercarse a la antítesis de ésta. El contexto de terror derivado de la guerra declarada al narcotráfico incentivó en el imaginario urbano la aceptación y adaptación a estas nuevas formas de vida en el hábitat urbano. Contradictoriamente, mientras la ciudad reproducía cada vez más áreas aisladas y con complejo de autosuficiencia, el sistema Metro por fin puesto en marcha, acortó aun más las distancias de la metrópoli.

\footnotetext{
${ }^{16}$ El plan vial se empezó a diagnosticar desde 1969 mediante la teoría de análisis modelísticos para el desarrollo urbano. En Medellín, este plan transformó el esquema longitudinal de la malla vial por uno radial, que impactó negativamente el centro de la ciudad, incrementando el valor del suelo debido a la concentración de servicios; y generando especulación del mercado inmobiliario. Transformó los límites del centro de la ciudad al conectarlo con los municipios vecinos (Ceballos y Vélez, 2002:16)

${ }^{17}$ UPAC (Unidad de Poder Adquisitivo Constante) fue el sistema crediticio que a partir de 1974 abrió las puertas a la banca privada para que se apoderará de la oferta inmobiliaria, desplazando a las empresas del Estado que desde los años treinta venían ejecutando las políticas de vivienda.

${ }^{18}$ Los desarrollos urbanísticos que amplían la frontera urbana requieren no sólo de altas inversiones en la construcción de infraestructura, que la operación del privado logra salvar, sino también en el mantenimiento de las mismas, que finalmente las administraciones municipales terminan asumiendo a través del fisco.
} 
Medellín entra al siglo XXI con una imagen de ciudad confusa, producida en gran medida por su proceso de crecimiento urbano en el que se aprecian áreas muy diferenciadas y con condiciones disímiles para el hábitat de sus ciudadanos. El sector financiero y de la construcción emprende un proceso agresivo de transformación del paisaje urbano, especialmente al suroriente de la ciudad que goza de prestigio en el imaginario urbano. Estas áreas caracterizadas por altas pendientes, un inadecuado sistema de movilidad, así como surcado por un número amplio de quebradas, termina siendo "sembrado" casi que por completo de torres en altura, en el que se aprecian extensas zonas verdes encerradas por mallas, donde lo único que entregan al espacio urbano son el diseño ostentoso de sus accesos y porterías.

Foto 8. Paisaje urbano caracterizado por una alta densidad constructiva de edificios en altura y por una baja densidad poblacional

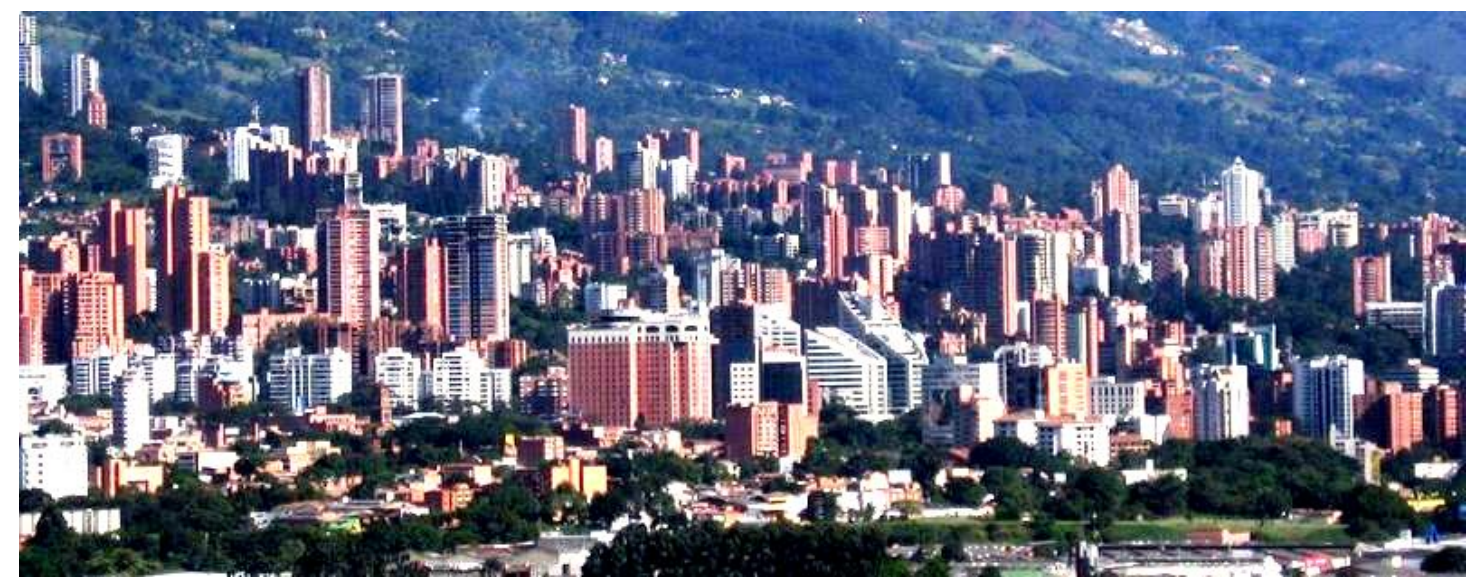

Fuente: Vive tu colombia, disponible en: www.vivetucolombia.com. Consulta: julio 25 de 2011

- Actuaciones urbanas para la entrada al club de ciudades marketing. Medellín 20002010

En los últimos diez años Medellín ha tenido un proceso de transformación en la que se manifiesta explícitamente el deseo de cambiarle la piel a la ciudad, con la intención política del Estado de hacer presencia más efectiva, sobre todo, en sectores con los cuales ha acumulado una deuda social de muchas décadas. Con este propósito, las dos últimas administraciones municipales han acuñado en la gestión pública el término "urbanismo social", ${ }^{19}$ el cual ha sido el eje de la transformación que propende por intervenciones integrales que incluyan funcionalidad y estética con un sentido dignificante.

La arquitectura ha sido instrumento en esta área de la gestión pública no sólo para: "recuperar el sistema soporte en comunidades que no lo tuvieron" 20 como propósito de la administración municipal, sino que también actúan como dispositivos simbólicos para recolonizar sectores marginales, que han venido construyendo territorios a través de lógicas en muchos aspectos apartadas de la formalidad estatal.

19 "Medellín, transformación de una ciudad". Sitio web: Scribid, disponible en: http://www.laboratoriomedellin.com/inico/component/tema/vertema/18.html\#urbanismo. Consulta: julio 15 de 2011

${ }^{20}$ Palabras de Carlos Mario Rodríguez (director de la Empresa de Desarrollo Urbano -EDU-) (2009). 
Por su parte, el sector financiero y de la construcción, habiendo ya casi acabado con el suelo urbanizable en el sector suroriental de Medellín, emprende ahora un proyecto colonizador de suelos que antes había descartado, especialmente en el suroccidente, empleando para esto estrategias de modificación del imaginario colectivo, con la intención de que estratos sociales medios y mediosaltos se localicen incluso en zonas que no han gozado de buena imagen. La ubicación de centros comerciales opera ahora como los detonantes de este proceso transformador, a tal punto de atreverse a cambiar la toponimia de sectores con tradición histórica y cultural.

Ilustración 3. Publicidad de nuevos proyectos del sector inmobiliario en el suroccidente de Medellín. En esta se refieren a un sector llamado Metrópolis, contiguo a un barrio (antiguo palenque) denominado tradicionalmente El Rincón
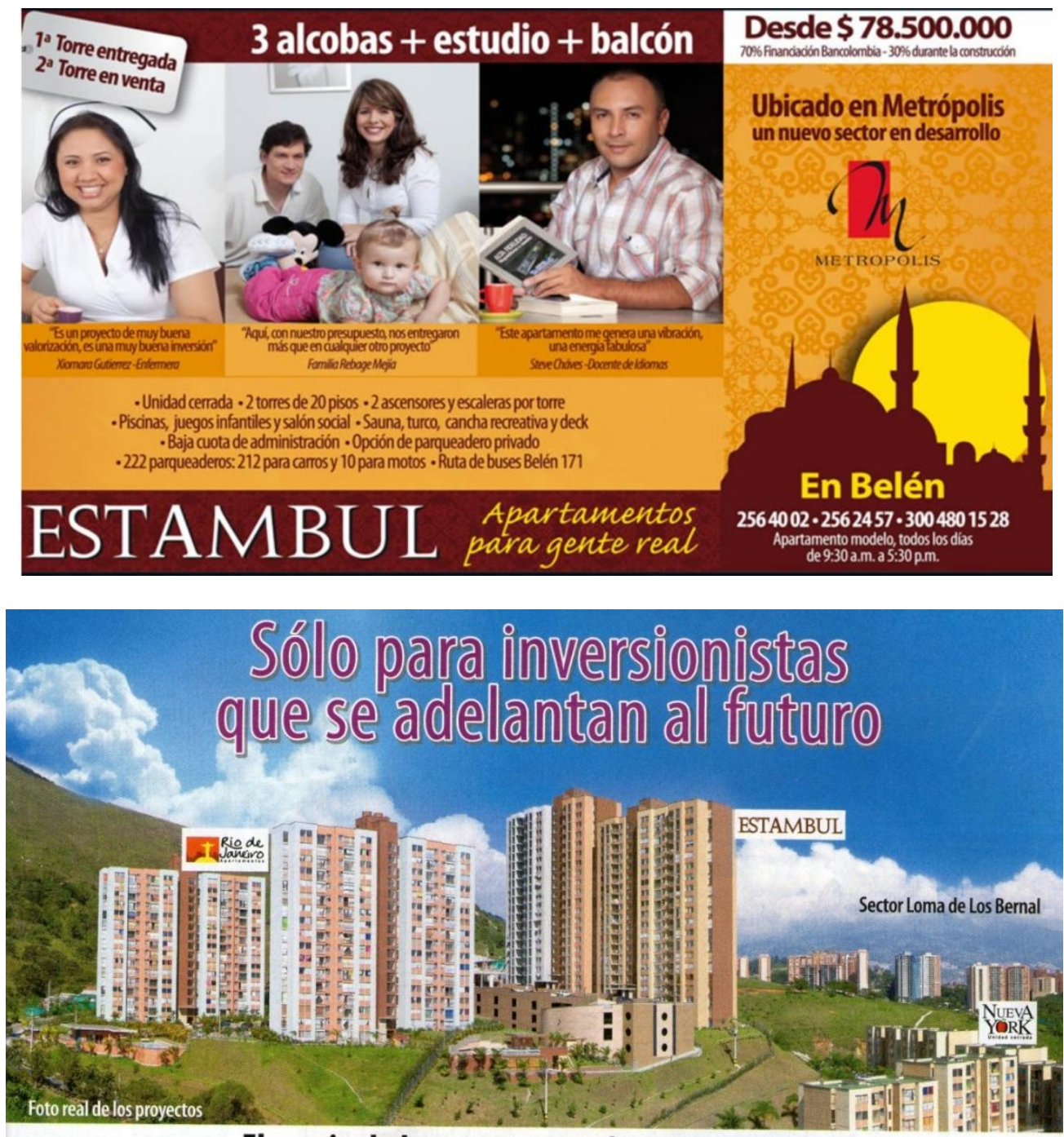

\section{El precio de hoy es una excelente oportunidad,} en cinco años su apartamento habrá tenido una alta valorización.

Antes de este plazo Estambul, todo Metrópolis y los proyectos vecinos que saldrán a ventas, habrán construido una vía que conectará todos esto: desarrollos con la Loma de Los Bernal, conformando así el barrio más campestre del occidente del Valle del Aburrá, con una hermosa vista a la ciudac

Fuente: Informe Inmobiliario de Medellín y su Área Metropolitana, junio de 2011. 
Ilustración 4. Promoción de la ciudad de Medellín en el portal electrónico del municipio

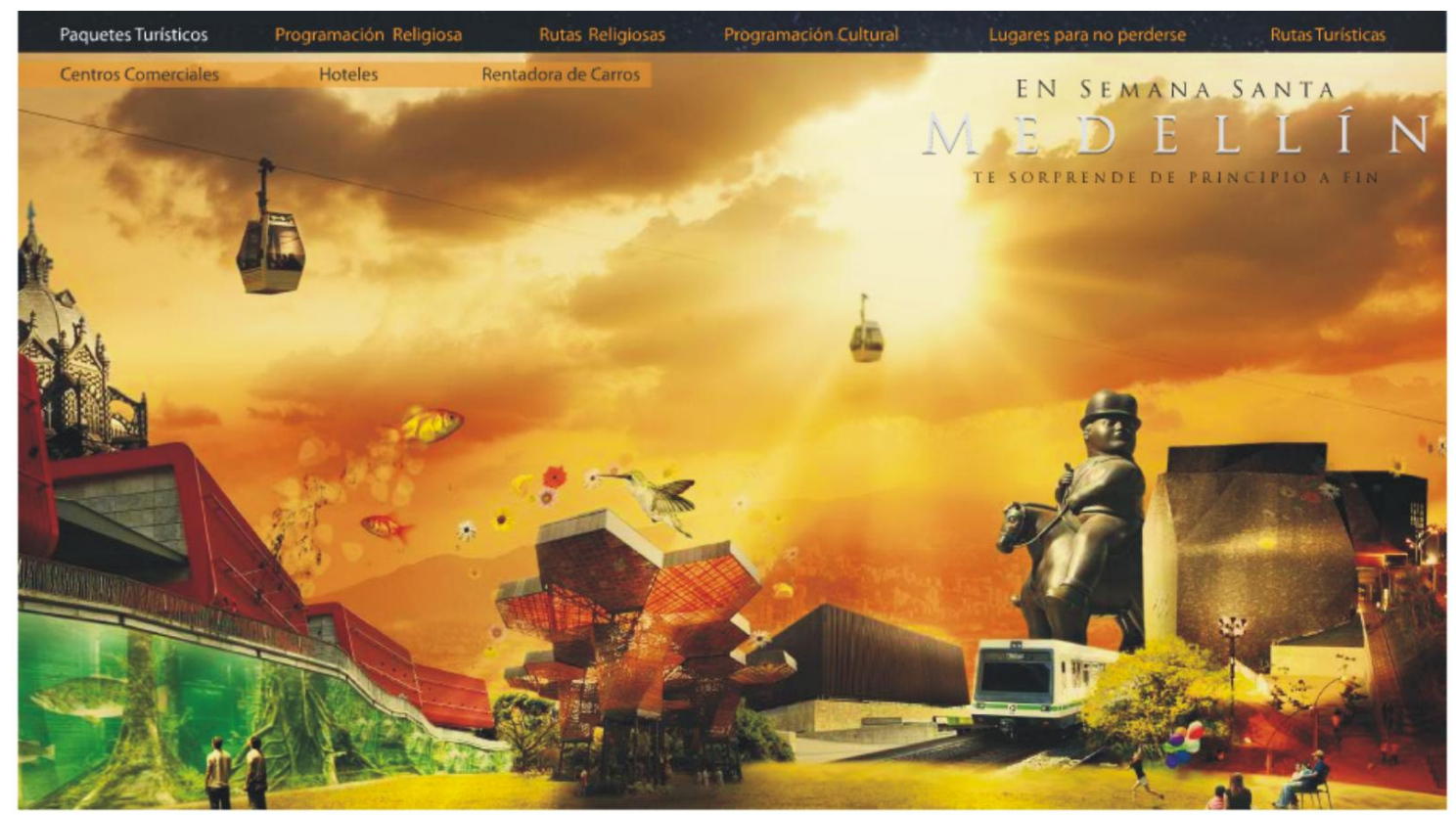

Fuente: Guía de Viajes Oficial de Medellín, disponible en:

http://www.medellin.travel/semanasanta2010/.Consulta: abril 2 de 2010.

Es necesario reconocer las diferencias que se observan en la construcción de un paisaje urbano de Medellín, desde su momento de excitación urbana en el que emprende un camino de abandono de la herencia colonial, rezago del que aún no se desprende; pasando por los albores de una élite burguesa liberal que intenta sintonizar con el espíritu moderno; atravesando una expansión urbana y crecimiento insospechado, alimentado por la llegada de innumerables campesinos en busca del bienestar social o huyendo de las estampidas del campo; continuando con la puesta en marcha del libre mercado del suelo, donde el Estado abandona la dirección del urbanismo y lo deja al arbitrio del sector financiero; hasta llegar a los intentos más recientes de una política pública local, que utiliza a la arquitectura como instrumento de recolonización simbólica sobre sectores tradicionalmente dejados a su suerte y refundando un nuevo sistema de centralidades que le permita acceder al club de las ciudades marketing.

\subsection{Estado del arte documental y bibliográfico y objetivos de la investigación}

Como se anotó en apartados anteriores, investigadores locales coinciden en afirmar que durante gran parte del siglo XIX Medellín no reportó significativas transformaciones en su paisaje urbano; a pesar de la inflexión histórica que significa la Independencia, la atmósfera de la ciudad continuaba teniendo un hálito dominantemente colonial. Sólo hasta finales de aquel siglo, se fueron sumando una serie de condiciones que permitieron que la antigua villa iniciara un proceso de transformación hacia una ciudad, al punto de liderar la industrialización en la órbita nacional en las primeras décadas del siglo XX.

Una de las condiciones con las que contó la ciudad para su transformación fue la educación técnica y universitaria, que a pesar de que ya tenía una tradición aproximada de ochenta años con la 
Universidad de Antioquia, sólo hasta la fundación de la Escuela de Artes y Oficios, y especialmente la Facultad Nacional de Minas, pudo disponer de técnicos especializados en temas tan fundamentales para la administración de la ciudad como la topografía y la elaboración de material cartográfico a través de métodos científicos.

Gracias a esto Medellín dispuso de su primer plano topográfico en 1875, el cual mostraba cómo la capital de la provincia de Antioquia era aún una acotada área urbana que no superaba cinco cuadras a la redonda de la Plaza Mayor instaurada por la colonia. Para ese momento la ciudad no contaba con más de treinta mil habitantes y no ocupaba una extensión de suelo mayor a las 90 hectáreas. Con este plano la administración municipal y la élite comercial obtienen un documento que les facilita reconocer las características de la ciudad y las posibilidades de extender aún más los límites de lo urbano sobre el territorio que se asienta.

Hacia 1899 la élite social y política de la ciudad conforma la Sociedad de Mejoras Públicas ${ }^{21}$ (SMP), la cual abogó para que la administración municipal actuara como gerente de los intereses privados en pro del desarrollo de la ciudad. Su insistencia fue tal, que a los pocos años se convirtió en un organismo consultor y asesor permanente del Concejo de Medellín (Botero, 1996). Entre los logros de esta élite dirigente fue que para 1911 la ciudad obtuviera un Plano de Medellín Futuro, promovido a través de un concurso. Para las bases de dicho concurso, así como para facilitar la implementación de las obras públicas requeridas por la ciudad, la administración municipal encargó a la firma Pearson \& Son, con sede en Londres, una actualización del plano de Medellín. Este fue entregado en 1908.

Hacia 1948 se produce otro hito significativo en cuanto a la elaboración de material cartográfico, relacionado con el Plan Piloto ${ }^{22}$ que adelanta la ciudad, bajo las prerrogativas del movimiento moderno, asunto que fue liderado por los arquitectos Wiener y Sert. Ya este material cartográfico se realiza a partir de información cartográfica base, suministrada por el IGAC ${ }^{23}$ que sienta las normas en el país en asuntos claves como la georeferenciación. A partir de allí, este mismo instituto comienza a producir periódicamente mapas que permitan revisar el crecimiento de las ciudades en el país, así como también constituirse en instrumento para los procesos de planificación local y regional. Para el caso de la ciudad de Medellín se dispone de mapas IGAC además de 1948, también de 1970 y 1985

El Área Metropolitana de Medellín con el Laboratorio de Urbanismo de la universidad Pontificia Bolivariana, en el 2004, adelantan un estudio de la forma urbana de las ciudades que integran el Valle de Aburrá. Los avances de esta investigación fueron recogidos, ya que había diferenciado las áreas que fueron agregándose en el proceso de expansión urbana, según lo permite corroborar los mapas IGAC, y digitalizados para facilitar su manipulación a través de los Sistemas de Información Geográfica.

\footnotetext{
${ }^{21}$ En el acta de fundación de la SMP se enuncia su propósito: “(...) el de que se asemejaba de lo que pasa en los centros civilizados, y aunando los esfuerzos y concentrando las voluntades se organice una junta encargada de velar por el ornato y embellecimiento de la ciudad" (Uribe Restrepo citado por Botero, 1996).

${ }^{22}$ La Ley 188 de 1947 obliga a los municipios en Colombia con una población mayor a los 100.000 habitantes a levantar un plano regulador de desarrollo urbano.

${ }^{23}$ Instituto Geográfico Agustín Codazzi.
} 
Ilustración 5. Información cartográfica que muestra la evolución del crecimiento urbano de Medellín

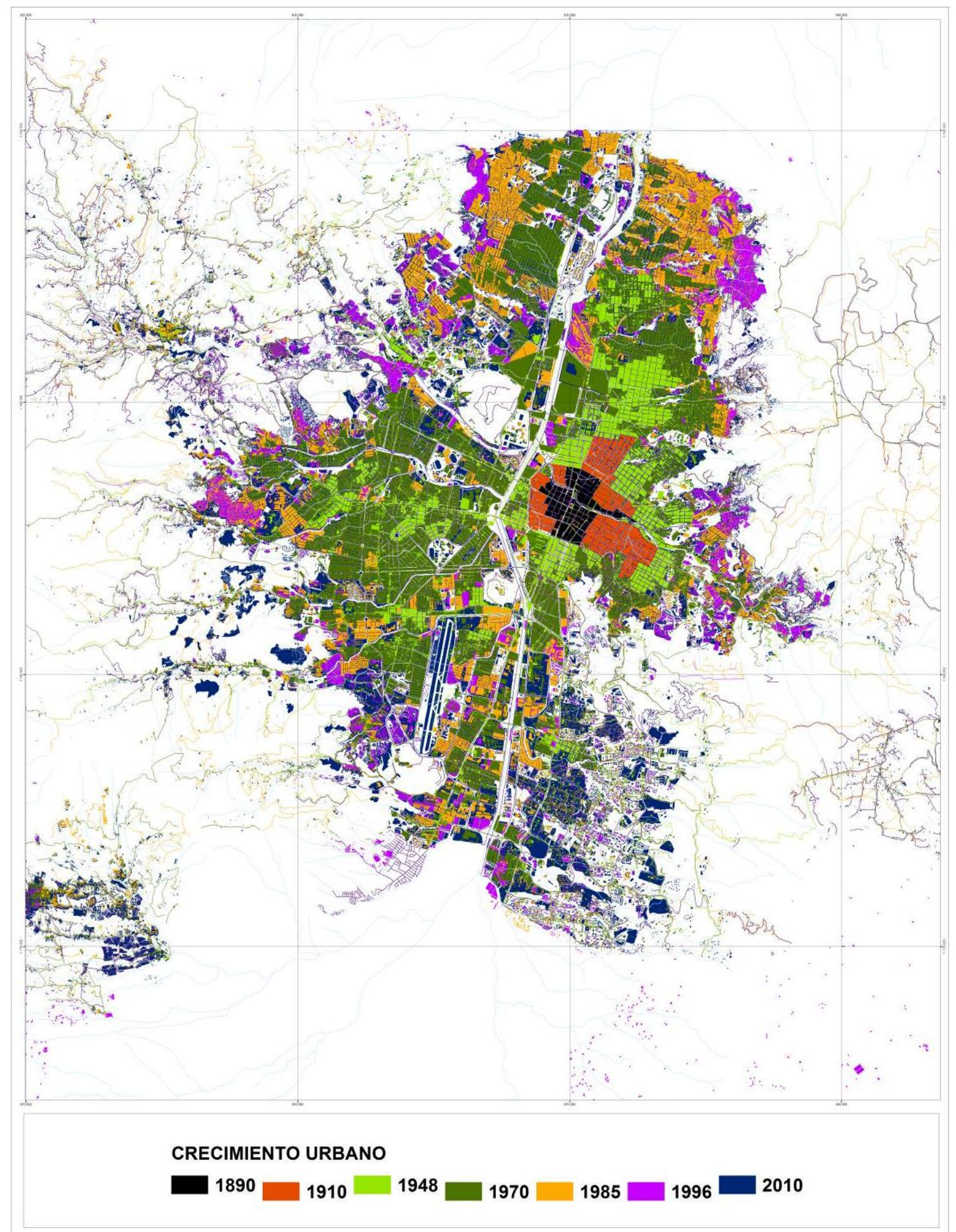

Fuente: ilustración elaborada por el autor con base en la cartografía POT de Medellín 2006, Estudio de La Forma Urbana del AMVA (UPB-Área Metropolitana, 2005) e imágenes de mapas oficiales previos a 1948 y posteriores a 1870 . 
Para completar el análisis en este sentido, también fueron consultados otros mapas elaborados entre 1910 y 1948 como encargos de la administración municipal, como el caso efectuado por el arquitecto Mariano Rodríguez en 1929 y por el departamento técnico del municipio en $1938 .{ }^{24} \mathrm{~A}$ partir de esta información cartográfica y de valiosas obras de varios autores locales como Fernando Botero (1996), María Teresa Uribe (1996), Fernando González (2007), Germán Rodrigo Mejía (2000) y Aprile-Gniset (1997); los tres primeros con énfasis en el caso de la historia urbana de Medellín, Mejía en el caso de Bogotá, y Gniset con un amplio estudio de las ciudades colombianas, permiten sugerir unas etapas de lectura de la transformación de la ciudad, la cual coincide con significativos hechos políticos, económicos, sociales, culturales y tecnológicos.

Para actualizar la información que se dispone de los estudios de los autores citados anteriormente, se acude también a la información que suministra la última revisión del Plan de Ordenamiento Territorial de Medellín efectuada en el 2006. Reunida toda esta información disponible, se procede a realizar un mapa que sintetiza las etapas de la expansión y crecimiento de la ciudad, material gráfico que facilita la caracterización de las capas urbanas o estratos narrativos, que se agregan en un lapso de tiempo no superior a 130 años, y que suscitan la dinámica de los bordes urbanos como vectores de transgresión semiótica, asunto que se tratará en los siguientes capítulos.

Otra tipo de información de vital importancia para el desarrollo de esta investigación es el cúmulo de fotografías que a través de la historia han registrado la transformación de Medellín. Luis Fernando Molina (2005), uno de quienes ha estudiado esta importante herencia cultural, señala que la fotografía en Medellín aparece, no de manera coincidente, ${ }^{25}$ a finales del siglo XIX, momentos en que la ciudad iniciaba un ritmo acelerado en su transformación urbana.

El material fotográfico que da cuenta de la trasformación urbana de Medellín de finales del siglo XIX hasta las décadas más recientes, ha sido recogido y publicado en amplios estudios y proyectos culturales. Además de la citada obra de Luis Fernando Molina (2005), se acudió entre otras fuentes al material digital: Un siglo de vida en Medellin ${ }^{26}$ proyecto cultural liderado por la Biblioteca Pública Piloto de Medellín, desde finales del siglo XX y que aún sigue reuniendo un importante y amplio registro fotográfico de la ciudad y la región.

\footnotetext{
${ }^{24}$ Ver en Anexos los mapas que fueron empleados para el estudio de la expansión del área urbana de Medellín.

${ }^{25}$ Fotografía, impresión y arquitectura fueron quizás los oficios o artes que evolucionaron de manera más rápida y con aceptable calidad en Medellín en los últimos años del siglo XIX. Todos tuvieron un origen y desarrollo marcadamente urbano, porque la ciudad era su espacio propio (Molina, 2005:12).

${ }^{26}$ Con el proyecto Un Siglo de Vida en Medellín, se inició a finales del siglo pasado la recuperación digital del patrimonio cultural de Colombia. Con una gran campaña de comunicaciones, se invitó a los medellinenses a que prestarán por unos minutos sus fotografías en puntos de escaneo situados en la Biblioteca Pública Piloto y en los principales centros comerciales de la ciudad; con éste método la ciudadanía facilitó cerca de 15.000 fotografías de sus álbumes familiares. El proyecto ha continuado reuniendo imágenes y se han realizado eventos similares en diferentes departamentos; hoy la Fundación Víztaz posee cerca de 100.000 fotografías con las que muestra las regiones de Colombia, en proyectos como esta nueva versión de Un Siglo de Vida en Medellín. Tomado de Memoria fotográfica de Medellín, disponible en: http://www.viztaz.com.co/unsiglo/bancodigital/ciudad.htm. Consulta: octubre 30 de 2011
} 


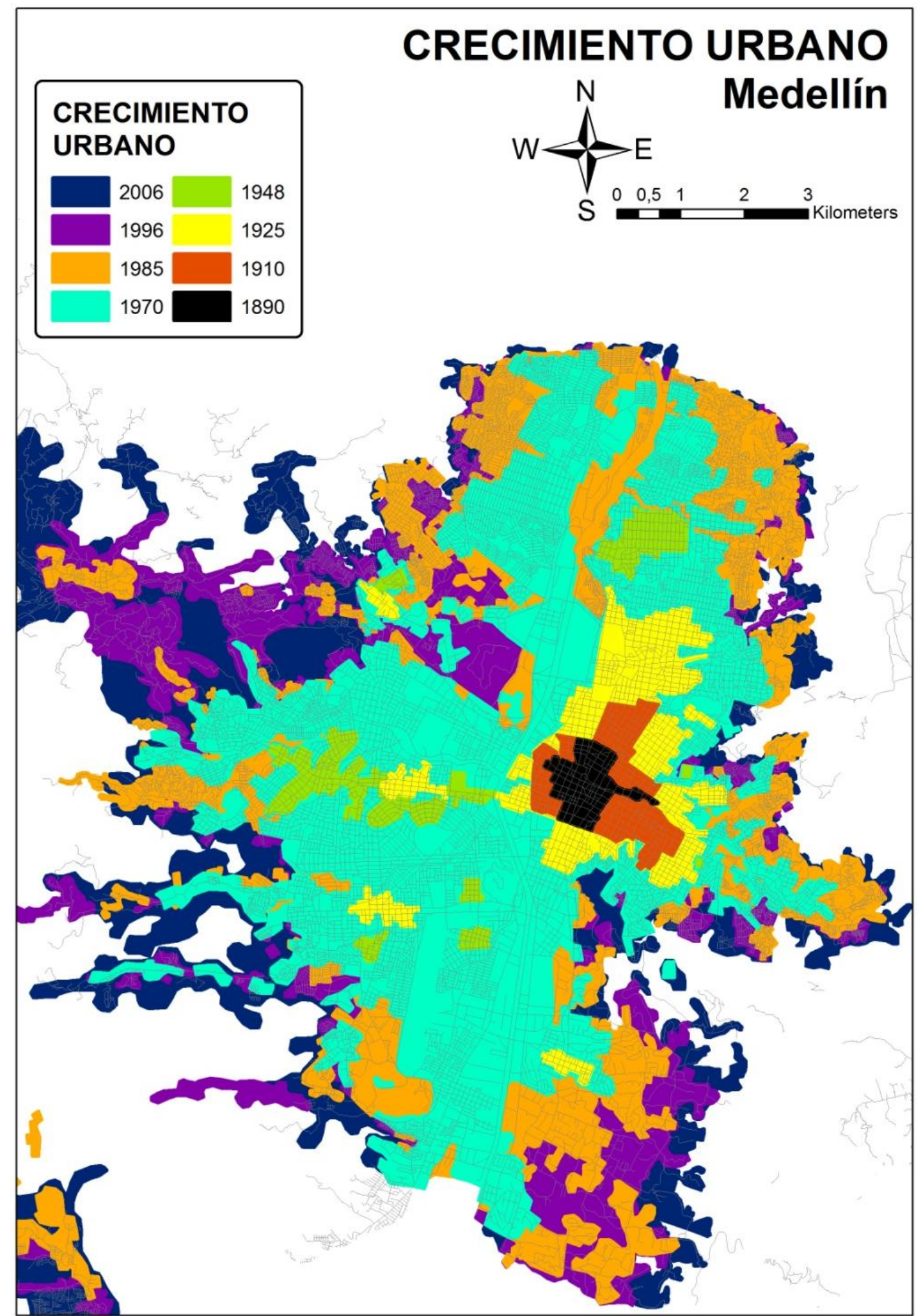

Fuente: ilustración elaborada por el autor con base en la cartografía POT de Medellín 2006, Estudio de La Forma Urbana del AMVA (UPB-Área Metropolitana, 2005), e imágenes de mapas oficiales previos a 1948 y posteriores a 1870 . 


\section{Memoria Fotográfica}

\section{Transporte}

Página 2 de 4
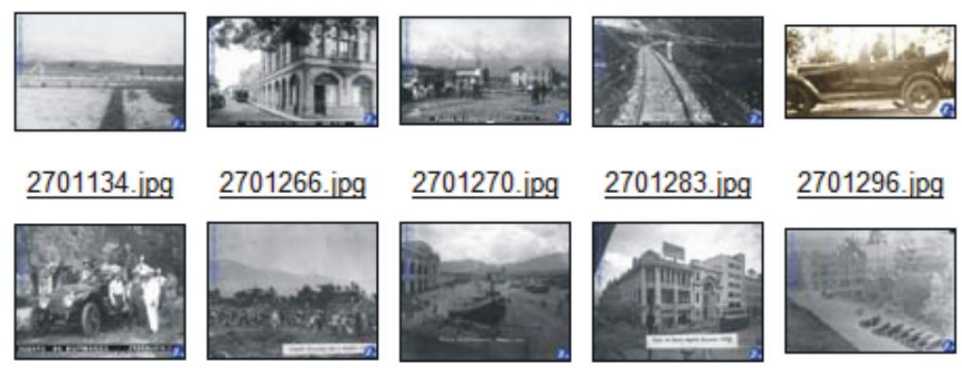

2701283.jpg

2701296.jpg

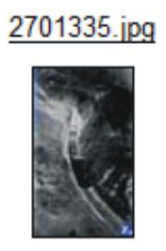

2701362.jpg

2701411.jpg
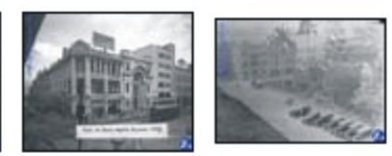

2701477.jpg
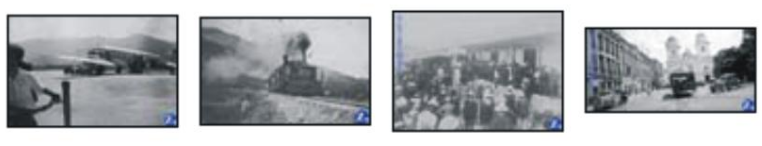

2701589.jpg

2702441.jpg

2702445.jpg

2702508.jpg

Fuente: Memoria fotográfica de Medellín, disponible en:

http://www.viztaz.com.co/unsiglo/bancodigital/ciudad.htm. Consulta: noviembre 15 de 2011

Con la información cartográfica y fotográfica disponible de la ciudad de Medellín, en lo que corresponde a la historia urbana desde finales del siglo XIX hasta la historia más reciente, esta investigación se propone, a través de las derivas del borde urbano, asumir dicha información como una categoría de análisis, que evidencia la transformación del paisaje. A través de una lectura del paisaje, desde una estrategia narrativa, se pretenden diseccionar algunas lógicas de producción de la ciudad; ya que a través del borde urbano que se multiplica y complejiza en el proceso de crecimiento y expansión de la ciudad, es posible mostrar los cambios, identificar las continuidades o permanencias y señalar dónde están las rupturas. En síntesis, se trata de revelar el efecto semiótico del borde urbano.

La lectura del paisaje desde una estrategia narrativa y del empleo de la información cartográfica y fotográfica disponible, recrea el borde urbano como escenario de mutaciones y cruces de las variables espacios, tiempos y actores, que al combinarse dibujan una dramaturgia del paisaje, una escenografía o puesta en escena, donde se producen una serie de modulaciones, de tipologías, de tramas y vectores.

Según lo anterior, se trazará un recorrido que ponga en evidencia la relación borde urbano-paisaje urbano. El juego y combinación de las variables, propone un ejercicio de recuperación de la memoria, para una gestión del paisaje urbano contemporáneo. 
- Ir a los paisajes de borde urbano. Una búsqueda para comprender las lógicas de producción del paisaje urbano

Las teorías narrativas de Ricoeur, Barthes, Senett y Berman, aportan categorías estético-culturales para una poética urbana. Rastrear el comportamiento de los bordes urbanos en la ciudad nos facilitaría el entendimiento de la transformación que acontece en el paisaje. Las categorías son tomadas como perceptores de cómo evoluciona en su materialidad, forma y función cada elemento del paisaje, y de cómo friccionan entre sí. Las anomalías que trastornan la vivencia y la percepción del paisaje, los lapsus de memoria que cotidianamente sufren los ciudadanos, son interpretados como rupturas o fronteras (zonas de turbulencia, zonas borrosas, espacios lisos o estriados, según Deleuze), proyectan situaciones narrativas en las cuales se esboza o dibuja los contornos de una experiencia del paisaje, sensible a los excesos de la memoria y a los excesos del olvido (Ricoeur, 2008).

En los bordes urbanos, tienen lugar escenas como el deterioro urbano, la pérdida del patrimonio cultural inmueble, la gentrificación, el estancamiento del dinamismo urbano, la saturación o excesiva intensidad de actividades urbanas, las fronteras "invisibles", escenarios de confrontación social violenta, la especulación irregular de la renta urbana, la segregación urbana y la supresión de escenarios de encuentro colectivo, el aislamiento de los individuos, la indiferencia entre los cuerpos que habitan la ciudad, en fin, varias anomalías urbanas que podrían ser reguladas por una "política de la justa memoria" (Ricoeur), nutrida de la lectura del paisaje del borde urbano desde una estrategia narrativa.

\section{- Objetivos o propósitos de la investigación}

\section{Objetivo general}

Hacer una lectura semiótica de las lógicas sociales de producción del espacio y de los discursos urbanos en la ciudad de Medellín en los cuales los imaginarios culturales emergen como acto que transgrede, actualiza y transforma el paisaje; el borde urbano es tomado como la unidad de análisis estructurante de un sistema de categorías que narra la crítica del cambio, de las tendencias del paisaje, y elemento expresivo de una imaginación en pleno movimiento que transforma el territorio

\section{Objetivos específicos}

- Hacer una reescritura en clave semiótica de los hechos más relevantes que constituyeron la materialización del paisaje urbano de Medellín, desde finales del siglo XIX hasta la primera década del XXI, a través de los datos y testimonios que ofrecen expresiones técnicoartísticas como la cartografía y la fotografía, producidas en la región durante este lapso y que recogen el proceso de construcción de ciudad y ciudadanía. 


\section{CAPÍTULO 2. FUNDAMENTACIÓN TEÓRICA, HIPÓTESIS Y METODOLOGÍA DE LA INVESTIGACIÓN}

La necesidad de una teoría narrativa para comprender las lógicas de producción del paisaje urbano, plantea a esta investigación la pregunta teórico-metodológica ¿Qué es narrar la ciudad?

Narrar, en el sentido de una metodología de la acción, es pensar e interpretar en movimiento la experiencia urbana en sus procesos de cambio. Comprender la transformación del paisaje urbano, bajo la lógica del movimiento, propone un trabajo de seguimiento del ritmo de las trayectorias del borde urbano, visualizado a partir de un amplísimo repertorio de imágenes.

La lectura del paisaje desde una estrategia narrativa permitiría la construcción de una técnica, tanto para la clasificación de los elementos, asumidos como símbolos, como también para la identificación de clases formales en la configuración del tiempo y del espacio, y por supuesto, para encontrar las reglas de combinación y transformación en el borde urbano. Esta estrategia de lectura de las derivas y direcciones del borde urbano para la configuración del paisaje abriría un análisis dentro de cada etapa o fase histórica (microestructuras), y a su vez, una exploración de tipo más amplio en relación a la influencia que cada uno de los tipos de borde urbano tiene en la configuración macroestructural de la ciudad.

El desplazamiento de ese modelo topográfico al texto urbano permite dar cuenta de los requisitos simultáneos y contradictorios de permanencia y borrado que caracterizan a la ciudad. Lo que justifica ese desplazamiento es que, a un nivel, en la ciudad nos enfrentamos a edificios y espacios que están siempre abiertos al cambio, a un nivel que tiene la capacidad ilimitada de transformarse. A otro nivel, nos enfrentamos también al plano urbano, que puede verse como el terreno en el que las trazas se graban y retienen indefinidamente mientras cambia todo lo demás. Pero existe también un tercer nivel, un nivel de fuerzas sociales y culturales, de prácticas e instituciones, que concilia a los otros dos, que hace posible la realización del espacio individual sobre suelo colectivo, que hace posible la transformación del tiempo en espacio, de la historia en geografía (Ramos, 2004:165).

Intentar construir una estrategia narrativa para comprender las lógicas de producción del paisaje urbano, es asumir la ciudad como superficie de escrituras donde esta presenta diversas capas de registro, y en donde la arquitectura añade capas de significado a la misma, con sus propios mecanismos de lectura (Ramos, 2004).

\subsection{Por la construcción de una teoría narrativa del paisaje}

Roland Barthes (1993) sugiere una técnica de los símbolos para describir la significación (semiología) y para facilitar el ejercicio metodológico de disociar el texto urbano en unidades, de tal forma que sea posible desarrollar clases formales que en su análisis permitan encontrar las reglas de combinación y de transformación que se aprecian como un fenómeno palpable en el paisaje de la ciudad: "La ciudad es un discurso, y este discurso es verdaderamente un lenguaje: la ciudad habla a sus habitantes, nosotros hablamos a nuestra ciudad, la ciudad en la que nos encontramos, sólo con habitarla, recorrerla, mirarla" (Barthes, 1993:260).

La estrategia narrativa como método de acercamiento para la lectura del paisaje, exige además superar la metáfora y pasar al análisis, atendiendo como el mismo Barthes expresa, que los 
significados tienen siempre una cierta imprecisión, al punto que se convierten en significantes de otra cosa: “(...) los significados pasan, los significantes quedan” (Barthes, 1993:262).

El borde urbano, en sus múltiples derivas y trayectorias, seguidas en el crecimiento y expansión de la ciudad, es tratado en esta investigación como un relato de la transformación del paisaje. Si la ciudad es una superficie discursiva (Ramos, 2004), es posible entonces distinguir en el paisaje urbano los componentes que fueron incorporándose en un relato que puede ser restituido desde las pesquisas a las derivas del borde urbano, registro de la expansión y del crecimiento de la ciudad. A través de un seguimiento de los cambios en el borde urbano se podrían hallar respuestas que surgen al intentar comprender el paisaje:

- ¿Cómo son las transformaciones de significado que el paisaje registra a través del tiempo?

- ¿Cómo son sustituidos o borrados algunos componentes en el paisaje y qué relación guardan con la inserción de otros componentes?

El paisaje, desde la lectura que nos ofrecen los bordes urbanos, a partir de una estrategia narrativa, abre la posibilidad de distinguir instancias de descripción (Barthes, 1993). Es decir, tipologías de borde, que en el caso de la teoría narrativa, nos trasladan a los diferentes tipos de escenografías urbanas, en donde, espacios, tiempos y actores, en sus diversas características, se encadenan en diferentes combinaciones. Las lógicas de producción del paisaje se desprenden de diferentes discursos urbanos alimentados por planteamientos ideológicos, que procuran moldear el espacio y el tiempo, y la sintaxis de los personajes.

Los bordes urbanos, en la narrativa del paisaje, aparecen como un instrumento que intenta afianzar el pensamiento imperante de la época, o por el contrario, que procura modificar el curso de las trayectorias del relato urbano produciendo cambios y transformaciones en el paisaje. Es en los bordes urbanos donde se aprecia el conflicto permanente entre las fuerzas que procuran mantener intacta los trazos de la ciudad, con otras fuerzas que insisten en modificar las estructuras existentes.

Esos conflictos apreciables en el borde urbano, desde la teoría narrativa, serían analizados como "lapsus" ${ }^{27}$ del texto urbano (Ramos, 2004), lugares donde se evidencian las rupturas, las zonas fronterizas, las divergencias y los contrastes. Y esa lectura del paisaje urbano en el tiempo, a través de los indicios apreciables en el borde urbano, desentrañaría las lógicas de su construcción y transformación, cuyas estrategias, acudiendo nuevamente a Barthes, irían desde el borrado, el ocultamiento, la reescritura y los cambios de significado.

\section{- La anamnesis y la amnesia urbana}

Según Ricoeur (2008), la anamnesis es el esfuerzo de rememoración que se ejerce a partir de los recuerdos traídos por los objetos a la memoria, precaviéndonos del olvido; en una economía de esfuerzos restituye el significado de las prácticas cotidianas. Es en el espacio habitado donde el ciudadano acude a las marcas exteriores como elementos de enlace para recuperar la memoria que ejercita, para darle sentido y significado a la localización y a las trayectoria de su propio cuerpo;

27 “¿Dónde tienen lugar esos fallos? En los márgenes donde colisionan las cuadrículas, y dentro de la cuadrícula, cuando se enfrenta a la fuerza de registros previos (historia y geografía) que no pueden borrarse completamente de la cuadrícula" (Krauss, 1997:64. Citado por Ramos, 2004:168) 
también, su relación con los otros, con quienes cohabita, e incluso con quienes ya no están pero hacen parte del imaginario colectivo.

La anamnesis urbana se materializa en los recuerdos de la experiencia corporal con el espacio y con el tiempo, en los cuales se reconoce tanto el fragmento de tierra habitable como las características del entorno. Pero también aparece en los lugares consagrados por la tradición, en donde la memoria colectiva restituye el significado y sentido de la situación presente (idea del pasado), y desde donde espera construir un lugar para el futuro: "El esfuerzo de rememoración consiste en convertir una representación esquemática, cuyos elementos se interpenetran, en una representación llena de imágenes, cuyas partes se yuxtaponen" (Ricoeur, 2008).

La anamnesis se produce en el espacio urbano en el que es posible desplegar la condición temporal, en donde los sujetos (actores urbanos) sienten la posibilidad de construir sus experiencias. En este caso el paisaje es producto de la configuración del tiempo, en donde los sujetos construyen una trama logrando que el espacio construido sea el mismo que el tiempo narrado. Ricoeur (2008) denomina al espacio construido como el espacio de fijación donde es posible habitar, pero donde es posible también la circulación para re-correr, y así finalmente, obtener un sistema de emplazamiento para las principales interacciones de la vida.

El paisaje donde la anamnesis tiene lugar, configura una escenografía donde los actores buscan "esperando encontrar y reconocer lo que una vez se aprendió" (Ricoeur, 2008). Para tal efecto, las huellas y los rastros son fundamentales para la activación del recuerdo, que desde un estado virtual se traslada a un estado actual. La huella adquiere una dimensión semiótica en la cual una representación desencadena la acción, un vínculo social, la supervivencia de las identidades que no son más que la supervivencia de las imágenes.

Ricoeur (2008), sostiene que el olvido es destructor; un ejercicio de la memoria en la que ya no se producen experiencias vivificadoras, sino sueños y simulacros, puede ser objeto de manipulación y de abusos. Para Manuel Delgado la memoria, en la construcción de la identidad urbana: el caso Barcelona, expresa una obsesión textualizadora, usada para conformar controladamente mapas mentales a partir de operaciones macrosemióticas y con efectos semiotizantes sobre el ciudadano, instrumentado en consumidor semántico de la ciudad.

Delgado insiste que este tipo de concepciones promueven una memoria trivializada y virtual, que a partir de escenografias seductoras, hace del territorio un espacio escolar, indicando al ciudadano: Qué ha de ser mirado y Cómo ha de ser mirado. Esta manipulación induce una política de multiplicación de lugares de memoria instrumentada, con la cual, determinados fragmentos del territorio son puestos en valor, en una reificación del espacio, donde los objetos son dotados de plusvalía simbólica (Delgado: 2010), en una palpable fetichización del lugar.

Para inducir una imagen de ciudad alucinante se recurre al criterio retórico de la redundancia, mediante la repetición de esquemas formales estandarizados, que como el mismo Delgado (2010) señala van a favor de una homogeneización estética, en las cuáles incluso se introducen mecanismos panópticos que deben sortear cualquier espontaneidad que surja en las calles y plazas. En esa repetición de hábitos y conductas, en la ciudad que abusa de la memoria y la impone a sus ciudadanos-consumidores, generan olvido en lugar del acto de recuerdo. Como Ricoeur (2008) lo señala, ya Freud había demostrado que esa compulsión de la repetición no es más que un síntoma del olvido, o de la memoria impedida. 
Si en el espacio de la memoria los cuerpos encuentran su lugar, en la ciudad, donde no es posible el ejercicio de la anamnesis, se produce el simulacro de los actores urbanos que pueden estar en movimiento y en una parálisis a la vez como paseantes, vagabundos y errantes.

En este caso la estrategia narrativa para la lectura de ese paisaje del olvido da cuenta de esos otros modos que se dan en la narración: supresión, desplazamiento o refiguración. Tales estrategias narrativas, derivadas de una manipulación de la memoria desde una postura ideológica imperante, promueven una historia que autoriza, la cual es no sólo impuesta, sino también celebrada y conmemorada.

La ausencia de anamnesis en la ciudad es la aparición de la amnesia urbana, que también hace empleo de recursos narrativos, que como Ricoeur (2008) menciona, configura una trama con el miedo y con el halago, en donde se intimida pero donde también se seduce. Los actores urbanos en este caso ya no ven la posibilidad de construir su espacio y su tiempo, más bien, asumen comportamientos semipasivos y semiactivos. Los actores evaden y esquivan la realidad presente, y asumen la postura de no querer informarse, lo que Ricoeur denomina olvido de elusión.

El paisaje producto de la política del olvido plantea la confrontación con el otro como una amenaza, provocando cambios radicales en la alteridad, ahora encaminados hacia el rechazo y la exclusión. El olvido, según Ricoeur (2008), es una manipulación de la memoria, es decir, de la disposición y distribución de las marcas exteriores en el espacio, que a partir de un discurso justificativo del poder construye una empresa de seducción e intimidación.

La crítica de Ricoeur (2008) y de Delgado (2010) denuncian la manipulación de la memoria en la proyección de la ciudad, ya que esta misma se convierte en un producto para volverla consumo y simulacro; en la que se promueve un estereotipo de identidad. La ciudad producto de una esquematización comercial, produce y vende un relato impuesto, una historia "autorizada". Una ciudad ahora tematizada, que en palabras de Delgado, insiste en desactivar para siempre lo urbano.

\section{- La ciudad, escenario de recurrencias y de itinerarios de la memoria}

Delgado, en una conferencia dictada en 1995, analiza la ciudad como representaciones mentales que persisten hasta tanto no surjan dispositivos, mecanismos y estructuras más eficaces que las sustituyan. Lo interesante es que estamos presenciando una cultura del cambio, a ritmos acelerados, donde se aprecian fenómenos inerciales.

Si la ciudad posee una memoria es porque existen estrategias que han tenido éxito, y éstas pueden ser reveladas en la producción de las recurrencias, a pesar de los dispositivos de cambio que no logran destruirlas. Si no hay memoria la ciudad no puede existir (Delgado: 1995), el asunto es hasta dónde dicha memoria es una impostura, es decir, un sistema arbitrario de los discursos ideológicos que clasifica y ordena los lugares, como a los componentes que se disponen y distribuyen dentro de estos.

"Los lugares existen porque la memoria los identifica, los nombra, los clasifica" (Delgado: 1995). Pero la memoria también dota de atributos y de significados a los lugares y sus componentes, y puede hacer de ellos un acto de sacramentalización. Los discursos ideológicos imperantes protocolizan la actuación de los actores urbanos, atando lugares que parecen dispersos a través de 
trayectos que los vinculan, determinando en dónde se inicia y en dónde se termina el ritual del espacio sacralizado.

Para lograr este efecto, quien o quienes tienen el poder, recrean itinerarios de la memoria, es decir, un diálogo entre lugares, a los que se les dota de un valor sobrenatural, como es el caso de los monumentos, a través de los cuales se intenta imponer una memoria. Como medio de contraste se establece que lo que está por fuera de estos trayectos tienen menor valor, por lo tanto se imponen fronteras para destacar cuál es la identidad común o autorizada. Los bordes urbanos, toman así el valor de improntas del relato del paisaje, donde se plasman diversas tecnologías de memoria, constituidas también en fronteras.

\section{- Las fotografías: registro de experiencias capturadas}

Para restituir los relatos que encierra el paisaje urbano, la fotografía se ofrece como la evidencia técnico-artística, tal vez más fiel a la realidad que se pretende revelar. En tal sentido Susan Sontag dice: "Una fotografía parece entablar una relación más ingenua, y por lo tanto más precisa, con la realidad visible que otros objetos miméticos" (Sontag, 2005:16).

Las imágenes fotográficas nos suministran datos e información del pasado y la relación que estas establecen con el momento presente. De esta manera, la lectura que nos ofrecen las fotografías, en este caso de la transformación de la ciudad, son reflejo de los gustos y la conciencia de la época en la cual fueron capturadas como registro de experiencia.

Sontag (2005) también advierte que la fotografía es un instrumento de poder ya que señalan "qué vale la pena mirar y qué tenemos derecho a observar". Reunir las fotografías en una especie de antología de las imágenes, para dar cuenta del proceso de transformación de la ciudad, no es más que mostrar la gramática urbana a la que apelan los relatos para definir hasta dónde practican la memoria (anamnesis) o hasta dónde promueven el olvido.

Las fotografias permiten la posesión imaginaria de un pasado irreal, también ayudan a tomar posesión de un espacio donde la gente se siente insegura

Aunque acontecimiento ha llegado a significar, precisamente, algo digno de fotografiarse, aún es la ideología (en el sentido más amplio) lo que determina qué constituye un acontecimiento (Sontag, 2005:31).

La fotografía como dato o información tiene un doble valor, ya que además de ser una fracción del tiempo también lo es del espacio. La fotografía misma es una evidencia de las fronteras trazadas entre la identidad (el discurso) autorizada, y aquellas otras imágenes que escapan del "disciplinamiento de la memoria" (Delgado, 2010).

El encuadre para capturar o separar la imagen de otras cosas o ponerlas adyacentes, plantea un problema de arbitrariedad o discontinuidad de la imagen fotográfica. Esto se puede apreciar en el relato que Sontag reconoce [...] en las entradas de muchos poblados Kodak instalaba letreros enumerando qué fotografiar. En los parques nacionales, los letreros indicaban los lugares donde los visitantes podían pararse con las cámaras" (Sontag, 2005:75).

De esta situación, Sontag deduce que el mundo al que asistimos actualmente se transforma en una serie de partículas inconexas e independientes. Por eso mismo sugiere que sólo lo narrativo podría 
ayudarnos a comprender las lógicas que producen las escenas que presenciamos. En esa misma historia que nos suministran las fotografías podemos encontrar las estrategias de producción del paisaje urbano, que Sontag discrimina como: rechazo a la identificación, desdén por los mensajes y pretensión de invisibilidad.

Continuando con los planteamientos de Sontag, la fotografía es una "ruina artificial" que permite aprehender las cualidades de un paisaje recreado en el pasado. Es por esto que la fotografía crea un efecto de dominio en el espectador que es la sensación de estar presente dentro de una escena que ya no existe. En este caso la fotografía es memoria, pues se constituye en objeto que representa la ausencia de una cosa recordada (Ricoeur, 2008). “(...) una fotografía no sólo se asemeja al modelo y le rinde homenaje. Forma parte y es una extensión de ese modelo; y un medio poderoso para adquirirlo y controlarlo" (Sontag, 2005:165).

Con los compendios de la historia fotográfica de una ciudad, se obtiene un material disponible con el cual armar esquemas de clasificación y almacenamiento. Pero más importante aún, recrear un sistema de información que para las utilidades de esta investigación admite construir una narrativa del paisaje a través de las revelaciones que nos dejan los bordes urbanos, como registros del cambio y la transformación, para comprender las lógicas de producción del paisaje: “(...) la tecnología ha transformado la fotografía en una herramienta incomparable para descifrar la conducta, predecirla y alterarla" (Sontag, 2005:168).

Al reunir las fotografías que dan cuenta del proceso de transformación de la ciudad, e iniciar una técnica de clasificación, la realidad, como expresa Sontag, "empieza a ser comprendida como una suerte de escritura que hay que decodificar". Las nociones de realidad e imagen en este caso son complementarias, al punto que ya no se sabe qué es más semejante a qué, las imágenes a la realidad, o la realidad a las imágenes. "Las colecciones de fotografías pueden usarse para elaborar un mundo sucedáneo, cifrado por imágenes que exaltan, consuelan o acicatean" (Sontag, 2005:173).

Una lectura del paisaje desde una estrategia narrativa, empleando las fotografías como material de alto contenido semiótico, allanaría el camino para responder a cuestionamientos de la producción del paisaje como objeto de consumo en una sociedad capitalista. ${ }^{28}$ Como por ejemplo: ¿qué conflictos cooptan las imágenes? o ¿qué instituciones emergen y nacen en un repertorio de imágenes y sus imaginarios? Y por supuesto: ¿cuáles son las tendencias que promueven en la sociedad?

Estas preguntas, interrogan la cultura en cuanto esta asume el estatus de objeto para dos própositos: subjetivizar la realidad como espectáculo para las masas, y a su vez, objetivizar la realidad para la vigilancia de los gobernantes (Sontag, 2005). Los cambios sociales son controlados en gran medida por los cambios que se introducen a través de las imágenes.

La necesidad del cambio es permanente ante la percepción de que todo es transitorio. El paisaje mismo, como objeto de consumo, es un proyecto construido prematuramente con la idea de la obsolescencia. Recordemos, como lo hace Sontag (2005), que consumir significa también quemar y gastar. Esta situación plantea entonces una necesidad continua de reabastecimiento, y las imágenes mismas son un medio para proveer este requerimiento.

\footnotetext{
${ }^{28}$ No olvidemos que el agitado inicio de la expansión de la ciudad de Medellín se da a finales del siglo XIX, coincidiendo con el tránsito de la villa colonial a la ciudad burguesa, promovida por la incursión del capital.
} 
Una lectura del paisaje desde una estrategia narrativa empleando el cúmulo de imágenes que nos ofrecen los archivos históricos de la fotografía, como registros palpables de la transformación y cambio de la ciudad, nos plantea además del análisis de los relatos que encadenan dichas imágenes, para comprender las lógicas de producción del paisaje, la posibilidad de realizar una especie de reciclaje, de las estrategias exitosas, de esas reminiscencias que persisten a pesar de la insistencia y el permanente cambio del presente. "Se necesita una ecología no sólo de las cosas reales sino también de las imágenes", "Las imágenes de las cosas reales están entremezcladas con imágenes de imágenes" (Sontag, 2005:184).

\section{- Los estratos narrativos en la lectura del paisaje}

En el numeral 1.2 se precisó que además de acudir a la fotografía histórica, que da cuenta de la transformación de la ciudad de Medellín, también se emplea la información cartográfica producida en momentos claves de ese mismo proceso de cambio. Este material permite el reconocimiento de los diferentes estratos narrativos o capas urbanas que fueron sobreponiéndose en el tiempo, y que en la actualidad configuran el soporte de la experiencia narrativa del paisaje.

Deleuze y Guattari (1994) desarrollan en su libro Mil Mesetas una teoría de La Geología de la Moral. Un planteamiento que recoge cómo el mundo que conocemos en superficie no es más que un proceso de estratificación, de planos que se superponen, incluso colisionan, provocando sedimentaciones y plegamientos en la cultura. Y agregan además, que en esta constante dinámica, ese mundo que conocemos no deja de desestratificarse, de descodificarse, de desterritorializarse.

La Real Academia Española define estrato como: "Conjunto de elementos que, con determinados caracteres comunes, se ha integrado con otros conjuntos previos o posteriores para la formación de una entidad o producto históricos, de una lengua, etc". Esta concepción llevada a la teoría narrativa, que intenta ser aplicada en la lectura del paisaje, nos plantea que esos componentes dotados de atributos y significado en el espacio urbano son y han sido parte de unos estratos o planos que dan sentido a su localización y su aparición en el tiempo.

Y aún más, que esos componentes pueden ser considerados elementos inestables sin son producto de la sedimentación que origina la superposición de estratos temporales, o al contrario, elementos de estructuras estables si son resultado de los plegamientos que desencadenan los movimientos de expansión y contracción del espacio a través del tiempo.

Tanto la sedimentación como el plegamiento implican unas formas propias, ya que los estratos son topológicos (Deleuze y Guattari, 1994). Las formas del plegamiento son más estables, pues estás centran, unifican, totalizan, integran y jerarquizan. Mientras las formas de la sedimentación son más inestables, estas tienden a separar, a desagregar, a amontonar sin un orden jerárquico. Es decir, como Deleuze y Guattari lo indican: "las formas implican un código, modos de codificación y de descodificación".

En el movimiento de la expansión y el crecimiento de la ciudad, los bordes urbanos evidencian procesos de estratificación, sedimentación y plegamiento cultural. Este enfoque permite descubrir qué varía y qué no varía en el tránsito de un estrato a otro, y captar sus oscilaciones, ya que "las relaciones formales o los enlaces pueden ser los mismos sin que las formas lo sean. Y las relaciones 
o conexiones formales tienen entonces necesariamente que efectuarse en formas y disposiciones completamente diferentes" (Deleuze y Guattari, 1994).

Tales tipos de formas, producidas en los procesos de estratificación, se comprenden por la distribución y disposición de los cuerpos de los actores urbanos en el espacio, y de la percepción que estos tengan del tiempo en cada época definida como hito en la lectura narrativa del paisaje. Estas formas en la medida de su aparición pueden adquirir diferentes propiedades, en razón de su capacidad de propagación en el espacio, en sus posibilidades de crecimiento, de evolución y de mutación.

Pero sería todo un error creer que esa capa central unitaria del estrato era aislable, o
que se podía alcanzar por sí misma y por regresión. En primer lugar, un estrato iba
necesariamente, y desde el principio, de capa en capa. Tenía ya varias capas. Iba de
un centro a una periferia, pero a su vez la periferia actuaba sobre el centro y formaba
ya un nuevo centro para una nueva periferia (Deleuze y Guattari, 1994:57).

Es posible inferir de estas reflexiones que en la medida en que se incorporan al espacio nuevos estratos o capas que amplían su dominio sobre el territorio, los elementos y componentes que se agregan al panorama terminan también apropiándose del centro, donde se originó la fuerza de expansión, alimentándose de nuevas fuentes de energía, y agregando nuevos componentes.

Con la lógica de agregaciones y anexiones en el movimiento espacial, la emergencia o plegamiento de nuevos estratos, recomponen en gran medida las capas precedentes, y dan formación a nuevos centros, que se agregan al núcleo central, que se descompone y deriva en sustrato de la nueva composición. El éxito de las estrategias que se emplean en los sustratos nuevos se mide en la capacidad que tienen de propagarse en el medio, incluso de terminar afectando la configuración del estrato asumido como punto de partida.

El nuevo desplegamiento espacial y temporal si tiene éxito, es poco a poco poblado, modificando el medio a partir de un nuevo código que es inseparable de un proceso de descodificación, que es inherente a él (Deleuze y Guattari, 1994). La descodificación puede, entre varias modificaciones formales, suscitar que antiguos componentes adquieran nuevos significados o provocar su desterritorialización, que a su vez puede iniciar procesos de reterritorialización en otros bordes ya configurados o en procesos de configuración. "De la capa central a la periferia, luego del nuevo centro a la nueva periferia, pasan ondas nómadas o flujos de desterritorialización que recaen en el antiguo centro y se precipitan hacia el nuevo" (Deleuze y Guattari, 1994:60).

La aparición de un nuevo borde urbano implica necesariamente la desterritorialización de algunos componentes semióticos, de existencias transitorias, que a su vez, como lo refuerzan Deleuze y Guattari, tienen un movimiento reverso, el de la reterritorialización, con pretensiones sedentarias, a través de formas promovidas por las migraciones, los estiramientos, las elongaciones y los plegamientos.

Las formas que emergen, se nutren tanto de la información que suministran los estratos sobrepuestos y plegados, guardados por los códigos de comportamiento, y hacen que los actores se asuman posicionalmente; pero también, las formas pueden iniciar un proceso de descodificación, planteando una nueva deriva en el espacio, configurando un vector, introduciendo nuevas pautas de comportamiento en la escena urbana. "Códigos y territorialidades, descodificaciones y desterritorializaciones, no se corresponden término a término: al contrario, un código puede ser de 
desterritorialización, y una reterritorialización puede ser de descodificación" (Deleuze y Guattari, 1994:61)

Los estratos temporales no se mantienen inmóviles, estos mantienen una dinámica constante, ya que pretenden moverse, desplazarse, ocasionando entre sí fracturas y rupturas. Estas dan soporte a la aparición de los bordes urbanos que se nutren de los sustratos, proporcionándoles los materiales con los que da forma a sus componentes. Dependiendo de la fuerza y la magnitud de la fricción, unos estratos en la sobreposición sólo dejan unas mínimas huellas (trazas), en otras, algunos estratos quedan prisioneros de otros y terminan sofocados, y otras fricciones o fracturas son de tal magnitud que terminan atravesando todas las estratificaciones, y construyen su propios esquemas e itinerarios, ahora sobre el estrato conquistado.

Cuando la afectación de un estrato sobre el otro es mínima, una nueva modulación se da en el espacio y en el tiempo, es decir, son los mismos componentes pero con disposiciones y distribuciones distintas. Pero cuando la afectación es considerable, dada la fuerza externa con que colisiona, es un nuevo molde el que se cierne sobre el panorama, dándose una transformación no sólo en la expresión sino también en el contenido.

Los estratos (capas o planos) que intentan extenderse y ampliarse en el espacio se desarrollan en los bordes urbanos, y por fuerza insisten en una redistribución de los componentes que conforman la escritura urbana presente. Para lograrlo apelan al uso de símbolos comprensibles, transmisibles y modificables, intentando que estos se repitan de manera indefinida y otorgándoles un valor superior que el que posee el mismo objeto. El borde por esto se convierte en una "máquina social técnica, que desde el estrato al que pertenece se eleva y tiende sus pinzas en todos los sentidos, hacia todos los estratos" (Deleuze y Guattari, 1994).

El borde que alcanza el estatus de máquina, se desborda en los otros estratos desarrollando una acción de desplegamiento, para colmar un dominio formal y semiótico, dándose la atribución de "escribir" e instaurar los nuevos significantes, es decir, modificando el relato, las características de los espacios, los tiempos y los actores. La descripción de este comportamiento, palpable en el mundo que conocemos, en las escenas urbanas que diariamente atravesamos, requiere, en términos de Deleuze y Guattari, de agenciamientos, en el que los distintos estratos siguen trayectorias de carácter metaestable.

\subsection{Metodología de la investigación: El borde urbano, un vector semiótico transgresor. Hipótesis o presupuesto de partida en la investigación}

El borde urbano es un vector semiótico que transgrede, estabiliza los factores compositivos, relacionales, espaciales, simbólicos y tecnológicos en la ciudad. Este se complejiza en el proceso de expansión y crecimiento del espacio urbano, ya que adquiere múltiples derivas o trayectorias y a su vez condensa las lógicas de producción del paisaje, lógicas que en la actualidad es necesario recategorizar para su comprensión, y desde allí refundar una gestión del paisaje urbano contemporáneo.

Para la comprensión de las lógicas de producción del paisaje urbano se apela a la construcción de una estrategia narrativa, restituida por los vestigios, las huellas y las trazas que dan cuenta del proceso de transformación y cambio del paisaje, en el caso de Medellín, desde finales del siglo XIX 
hasta los años más recientes de su historia. El paisaje de borde urbano considerado un texto narrativo plantea el reconocimiento de situaciones o instancias de descripciones (Barthes, 1993), en las cuales se aprecian los cambios en los espacios, en los tiempos y en los actores, y cómo en múltiples combinaciones entre estos componentes del paisaje aparecen escenografías urbanas, productos de diferentes discursos y relatos que pujan por dirigir la ciudad.

La pesquisa de los cambios apreciables en los componentes del paisaje: espacio, tiempo y actores, a través de los discursos imperantes en cada una de las épocas o momentos de la historia urbana de Medellín, permite allanar el camino para nombrar esas escenografías del paisaje, que son condensadas, atrapadas, desbaratadas, acalladas y promovidas desde los bordes urbanos. Nombrar equivale a categorizar, y estas acciones facilitan la comprensión de las trayectorias que han seguido y siguen los bordes urbanos en la ciudad, promoviendo procesos de desterritorialización y de reterritorialización, procesos que exigen una gestión para una intencionada intervención paisajística.

A continuación se relacionan las categorías empleadas en la investigación, no sólo para comprender el comportamiento transgresor del borde urbano y su incidencia en la producción del paisaje urbano, sino también para acercarse a una propuesta de gestión del paisaje contemporáneo. Dichas categorías son necesarias: unas para allanar el camino y comprender las combinaciones que los elementos semióticos realizan en cada uno de los tropos urbanos, producidos en la expansión y crecimiento de la ciudad; otras para renombrar las situaciones que acontecen en el paisaje contemporáneo de Medellín, producidas en el entrecruzamiento de los estratos narrativos, así como por las diferentes estrategias narrativas que se derivan de las colisiones entre estas capas de registro de la transformación del paisaje. Y finalmente, las categorías que nombran los tipos de bordes urbanos a partir de las características que les define el proceso de transformación cultural, evidenciado en el posicionamiento $y$ en las trayectorias de los actores urbanos. 
Ilustración 8. Diagrama de categorías y sus relaciones de dependencia

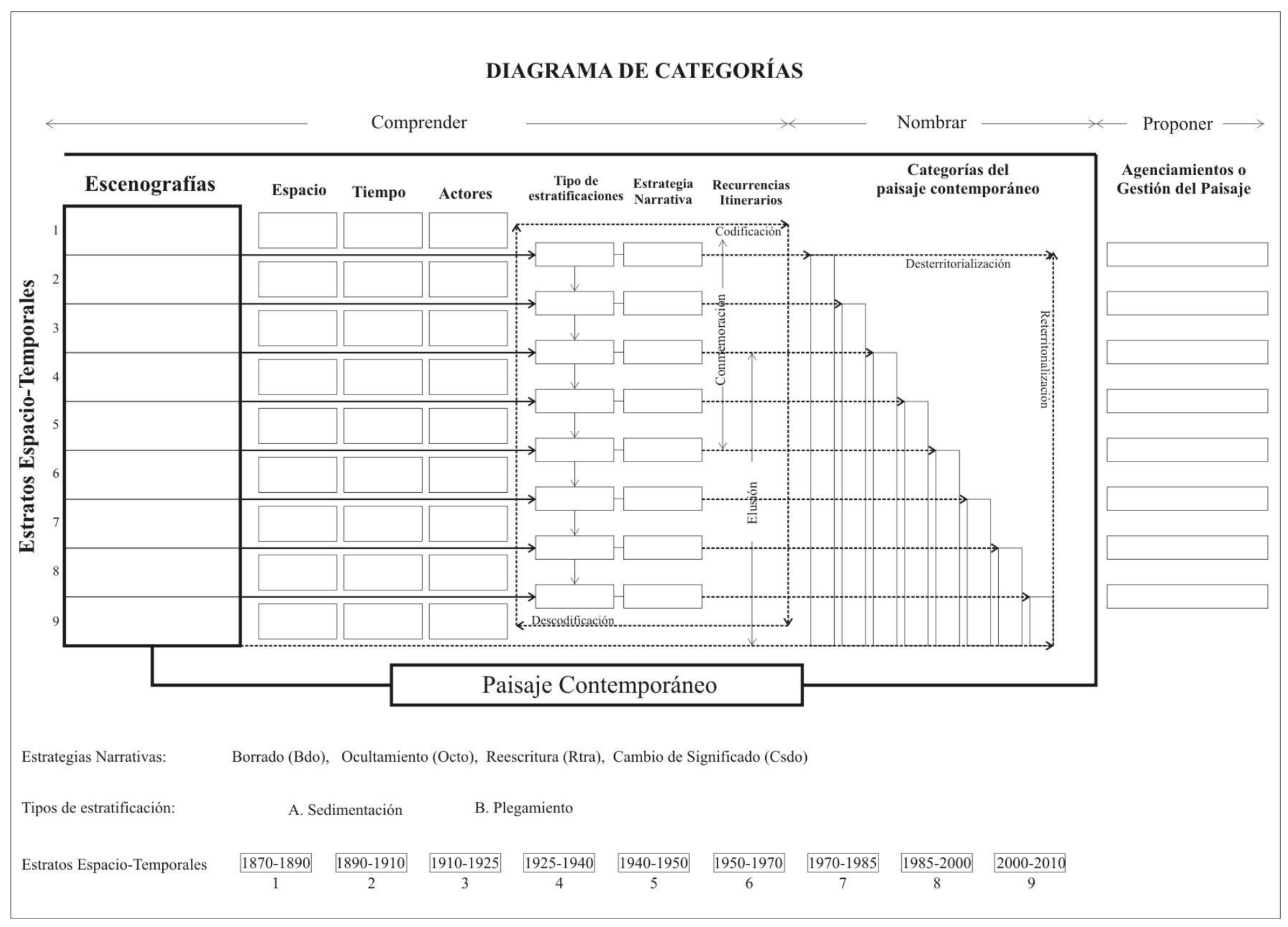

Fuente: ilustración elaborada por el autor. 


\section{- Categorías para la comprensión de los cambios producidos en el los bordes urbanos}

Para describir y clasificar las diferentes escenografías urbanas que se producen en las transformaciones del paisaje, es necesario constatar los cambios que se aprecian en los componentes del mismo: el espacio, el tiempo y los actores. Los discursos imperantes en cada uno de los estratos espaciotemporales determinan, en cada caso, unas reglas para la organización formal de cada uno de estos componentes (gramática del paisaje).

Los atributos que asumen tanto el espacio, el tiempo y los actores, están determinados por el discurso predominante en la época o momento histórico referido. Para verificar las cualidades específicas en cada tropo urbano, se apela tanto a la re-presentación de las imágenes fotográficas de la época correspondiente como a las trazas que aún persisten en el tejido urbano, para ser finalmente asociadas a categorías estéticas que se desprenden de la teoría urbana, especialmente la desarrollada por Richard Sennett (2002).

Lo anterior en cuanto a las características que se desprenden de cada uno de los estratos o capas de registro de la expansión y del crecimiento urbano. Pero para los lapsos o transiciones entre una estratificación a otra, se requieren otro tipo de categorías que expliquen la colonización de una nueva capa de registro, sobre las preexistentes. Para tal efecto se acude a las propuestas por Deleuze y Guattari (1994) en su "Geología de la moral", sedimentación y plegamiento, a las cuales se asocia en cada caso a formas inestables o estables que determinan los niveles de dinamismo en la transformación del paisaje.

Para ahondar en la comprensión del cambio y transformación del paisaje, según los vestigios encontrados en los bordes urbanos, el paisaje como texto narrativo revela las estrategias que cada una de los nuevos estratos o capas de registro (escritura) emplean para la colonización del espacio urbano. Barthes (1993) en tal caso, como ya se mencionó anteriormente, sugiere para desentrañar las lógicas que los discursos introducen a los relatos, acudir a categorías como el borrado, el ocultamiento, la reescritura y los cambios de significado.

Finalmente, en lo que se refiere a las categorías de comprensión de las lógicas de producción de paisaje, es necesario confrontar las dinámicas que generaron el proceso de transformación del paisaje, con la lectura que nos ofrece el panorama actual. Se apela entonces a la identificación de itinerarios y recurrencias que se aprecian sobre el paisaje urbano contemporáneo, en la procura de reconocer conflictos que pueden estar sucediendo entre las estructuras de memoria y las estructuras funcionales. Esta fase de comprensión consiste en verificar lo que Ricoeur (2008) y Delgado (2010) denominan estrategias de memoria y olvido en la construcción de la identidad urbana.

\section{- Categorías para renombrar las escenas que ofrece el paisaje contemporáneo}

Uno de los resultados de esta investigación será nombrar los tipos de borde que se aprecian en el paisaje urbano contemporáneo de Medellín. Las fricciones y las colisiones entre los diferentes estratos, que producen los discursos que ha construido la ciudad, originan rupturas y brechas en el paisaje que deben reconocerse y comprenderse. Dependiendo de su velocidad de propagación en el 
espacio urbano, de la pérdida de componentes en los procesos de cambio de estratificación, de sus niveles de crecimiento y mutación, se le asignarán los nombres que se consideren más apropiados en una especie de tipología de bordes urbanos.

Aplicando las teorías de Deleuze y Guattari (1994) en su "Geología de la moral," los tipos de borde serán discriminados en dos grandes categorías, una de estas referida a la desterritorialización cuando las estructuras y formas del paisaje sean predominantemente transitorias, inestables o nómadas, y la otra asociada a la reterritorialización, cuando las estructuras muestren mayor estabilidad y sus relaciones más localizables o sedentarias.

Se apreciarán seguramente algunos tipos de borde que logran traducirse (transportarse) en estratos de formación más reciente, en el proceso de reconfiguración del paisaje, mientras otros, por ejemplo, adquirirán la fuerza para elevarse y superar las fronteras, y así, influenciar y determinar otros estratos. En cada caso, se apreciarán modulaciones en el espacio y en el tiempo que modifican las posiciones y distribuciones de los componentes del paisaje, que a su vez, determinan los itinerarios de los actores urbanos.

\section{- Estrategia narrativa o sistematización de las evidencias iconográficas}

Construir una lectura del paisaje desde una estrategia narrativa, requiere del registro y sistematización de las evidencias cartográficas y fotográficas, cuyo propósito es identificar los componentes semióticos de la expansión urbana en cada uno de los momentos históricos, reconocidos como etapas de la configuración del paisaje urbano de Medellín. Estos últimos, motivados y materializados en contextos ideológicos específicos en la manera de concebir el espacio urbano.

En la actualidad, algunos de estos componentes identificados representan bordes urbanos de la experiencia perceptiva de grupos, individuos y conglomerados humanos. Gracias a esto es posible restituir diferentes tipos de itinerarios urbanos, dominados en distintos niveles por estructuras en las que la memoria y el olvido plasman sus signos, sus marcas y huellas; en las que el ciudadanoconsumidor repite, replica o rememora actos dentro de una teatralidad o simulacro civilista (Delgado, 1998).

Capturar la experiencia perceptiva de quienes narran el paisaje urbano a través de la lectura de la imagen urbana, está asociada al inventario de material cartográfico y fotográfico, respaldado en un enfoque crítico de la historia y la estética. Ir al paisaje, ofrece la revelación de lógicas de producción, expresados en objetos acumulados a través de la historia de la ciudad, en los cuales apelmazan valores residuales (caracterizados como ruinas o detritus), pero en los que permanece el hálito de las derivas del paisaje.

Esto exige superar la contemplación del paisaje como telón de fondo y comprenderlo como el vector que cambia de dirección, delineando derivas y trayectos, es decir, diversas configuraciones espaciales y temporales que los ciudadanos interpretan como escenarios de comportamiento. Las más claras evidencias de este asunto son las posiciones y actitudes que asumen los actores urbanos dentro de cada escenografía urbana, escenografía que sufre modificaciones alterando las posiciones 
y actitudes de los roles urbanos, ocasionando desplazamientos y desviaciones en las trayectorias y los itinerarios que siguen los ciudadanos.

La lectura del paisaje desde una estrategia narrativa permite la construcción de una técnica no sólo para la clasificación de los elementos, asumidos como símbolos, sino para la identificación de clases formales en la configuración del tiempo y del espacio, y por supuesto, para encontrar las reglas de combinación y transformación en el borde urbano. Esta estrategia de lectura de las derivas

y direcciones del borde urbano para la configuración del paisaje facilita un análisis dentro de cada etapa o fase histórica (microestructuras) y a su vez, un análisis de tipo más amplio en relación a la influencia que cada uno de los tipos de borde urbano tiene en la configuración macroestructural de la ciudad.

Kevin Lynch, reconocido teórico del diseño ambiental, sugirió e implementó varias técnicas de aproximación subjetiva a los lugares. En uno de sus libros, Administración del paisaje (1992) describe algunos métodos que se consideran apropiados para ser retomados con las adaptaciones que exigen los propósitos específicos de esta investigación. También se acude a algunos presupuestos metodológicos de Armando Silva (1994), investigador asiduo de los imaginarios urbanos, quien especialmente reconoce los lenguajes de la cultura contemporánea, especialmente del contexto latinoamericano.

Este último autor insiste que son los ciudadanos los que crean la noción de lo urbano, quienes construyen la experiencia paisajista, a lo que alude Silva interpretando a Freud: "La ciudad no existe, es una construcción que hace el hombre, y en cuanto esa construcción existen dos registros, lo simbólico y lo imaginario". Esta misma línea teórica plantea un problema metodológico que nos obliga a preguntarnos: ¿Cómo podemos acercarnos al hombre que habita la ciudad y la construye? ¿Cómo desde distintas técnicas apreciar esa construcción que hace el hombre de su misma urbanidad?

Es necesario para esto encontrar la manera de registrar diversos puntos de vista de ciudadanos y no dejar de lado la representación mediada por la tecnología, guiada por intereses ideológicos y culturales (Silva,1994). Este mismo autor ha podido corroborar cómo en las ciudades latinoamericanas se ha dado un desplazamiento del centro, lo que ocasiona también variaciones en los modos de representar y recorrer la ciudad. Con relación a esto acuña: "En una ciudad lo físico produce efectos en lo simbólico: sus escrituras y representaciones. Y que las representaciones se hagan de la urbe, de la misma manera, afectan y guían su uso social y modifican la concepción del espacio" (Silva, 1994).

\subsection{Instrumentos para la lectura de la transformación del paisaje de borde urbano}

\section{- Matriz de la expansión urbana para el inventario de objetos que configuran el paisaje urbano}

Para la construcción de una herramienta de tipo diagramático, que permita restituir la organización formal del paisaje urbano y los sistemas semióticos que la constituyen, se emplea como insumo la cartografía histórica de la ciudad de Medellín desde finales del siglo XIX, cuando inicia su apogeo 
urbano, hasta el año 2006, cuando se realizó el último proceso de revisión del Plan de Ordenamiento Territorial. También es necesario revisar las fotografías que registran la transformación del paisaje urbano, de finales del siglo XIX hasta mediados del siglo XX, ya que la fotografía tuvo una relación estrecha con la arquitectura pues los primeros fotógrafos de esta ciudad fueron quienes comenzaron a captar, con sentido estético y técnico, el espacio exterior e interior; ${ }^{29}$ dicha relación fue posible gracias a que los primeros fotógrafos fueron los primeros arquitectos y constructores de la ciudad burguesa.

Avanzado ya medio siglo XX aparece la fotografía profesional aérea empleada como instrumento para el control catastral de la ya significativa ciudad sobre el Valle de Aburrá. Y por supuesto, en los últimos años, se dispone de un material vasto y amplio, gracias al surgimiento de la cámara digital, donde tanto profesionales como aficionados capturan imágenes desenfrenadas de la acuciante cotidianidad.

Obtenida esta información es posible ordenar los elementos que han venido configurando el paisaje urbano en el transcurso del tiempo, así como en la dilatación y la contracción del espacio, de tal forma que se logre proyectar los encadenamientos, que actores, espacios y tiempos han conformado bajo estructuras sintácticas. Para tal efecto, la matriz la conforman dos ejes, uno de los cuales mantiene el hilo horizontal en el que se relacionan la sucesión de fragmentos que muestran el movimiento de los estratos narrativos, y el otro, el vertical, señala las fisuras y rupturas que producen las colisiones entre los diferentes estratos narrativos de la ciudad, vectores que muestra el comportamiento del borde urbano.

Con este instrumento diagramático es posible reconocer cada una de las microestructuras narrativas que se incorporan al paisaje, como deriva específica del borde urbano en un momento o lapso de tiempo determinado, siguiendo la lógica del eje horizontal de la matriz. Y revisando la lógica vertical, en una lectura transversal en el tiempo, es posible desentrañar las lógicas de localización de componentes de orden arquitectónico que siguen diferentes estrategias de colonización del espacio.

\section{- Muestreo regularizado. Mosaico de imágenes}

Acudiendo a la cartografía disponible de la ciudad de Medellín, se identificarán cada uno de los estratos narrativos, producto de la expansión urbana, e identificados en el primer capítulo como antecedentes históricos. Obtenidos estos estratos se procede a señalar el recorrido que cada uno de estos delinea sobre la configuración actual de la ciudad, sendas que sirven de guía para la captura de un registro fotográfico. Esto da como resultado un mosaico ordenado de imágenes que conforman cada uno de los ambientes urbanos objeto de estudio.

\footnotetext{
${ }^{29}$ La fotografía combinada con la educación ofrecida en la Escuela de Artes y Oficios y con las enseñanzas de los técnicos formados en el exterior, significó para algunos arquitectos-fotógrafos-pintores antioqueños, la posibilidad de salir de los gabinetes a fotografiar la ciudad para satisfacer la demanda de postales, o simplemente para trabajar en búsquedas técnicas y estéticas. La fotografía y la pintura de tema urbano se convirtieron en un producto comercial con demanda por parte de visitantes, periódicos locales y nacionales, instituciones públicas y privadas, como la Sociedad de Mejoras Públicas. (Molina, 2001:13)
} 
Con el registro fotográfico de cada estrato narrativo se procede a identificar las unidades constructivas del paisaje más relevantes, distinguiendo la forma, las tipologías urbanas, y, desde un punto de vista más fenomenológico, los "Escenarios de comportamiento" (Lynch, 1992). Este primer momento de aproximación permite hacer unas asociaciones entre la forma del espacio urbano y los comportamientos sociales que con dominio los caracterizan. El reconocimiento de los comportamientos ciudadanos en cada uno de los estratos narrativos, en los que se efectúa el trabajo de campo, se realiza a través del reconocimiento de las actitudes que asumen los actores en cada uno de los escenarios, donde la apreciación del tiempo y del espacio se experimenta en diversas formas y circunstancias.

Ilustración 9. Matriz de la configuración del paisaje urbano. Eje cronológico y eje tipológico

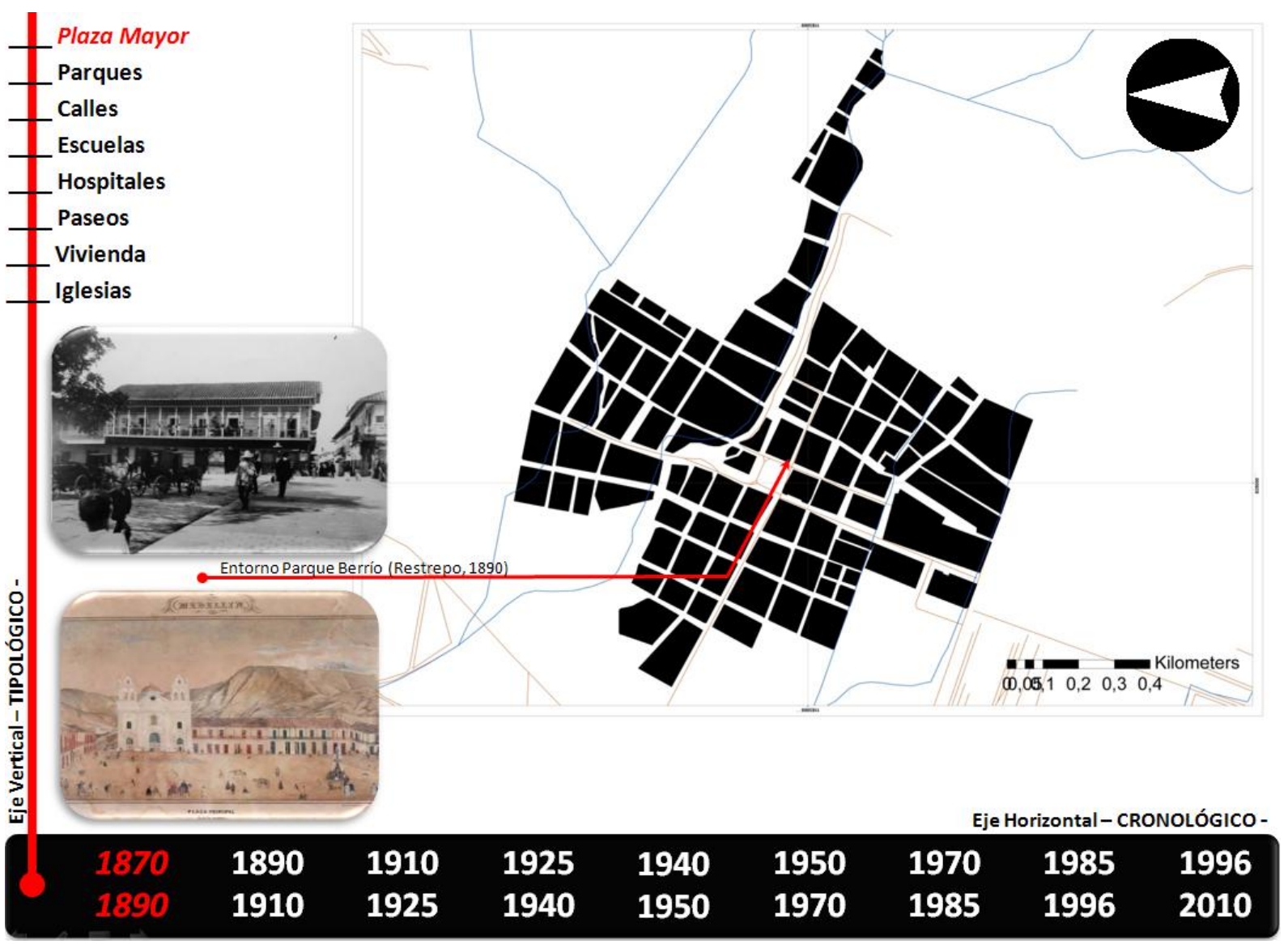

Fuente: ilustración elaborada por el autor.

A decir verdad, los desplazamientos del cuerpo e incluso su permanencia en el lugar no se dejan expresar, ni pesar, ni siquiera, en última instancia, experimentar, sin alguna referencia, al menos alusiva, a los puntos, las líneas, las superficies, los volúmenes, las distancias, inscritos en un espacio separado de la referencia al aqui y al allí inherentes al cuerpo propio (Ricoeur, 2008:193) 


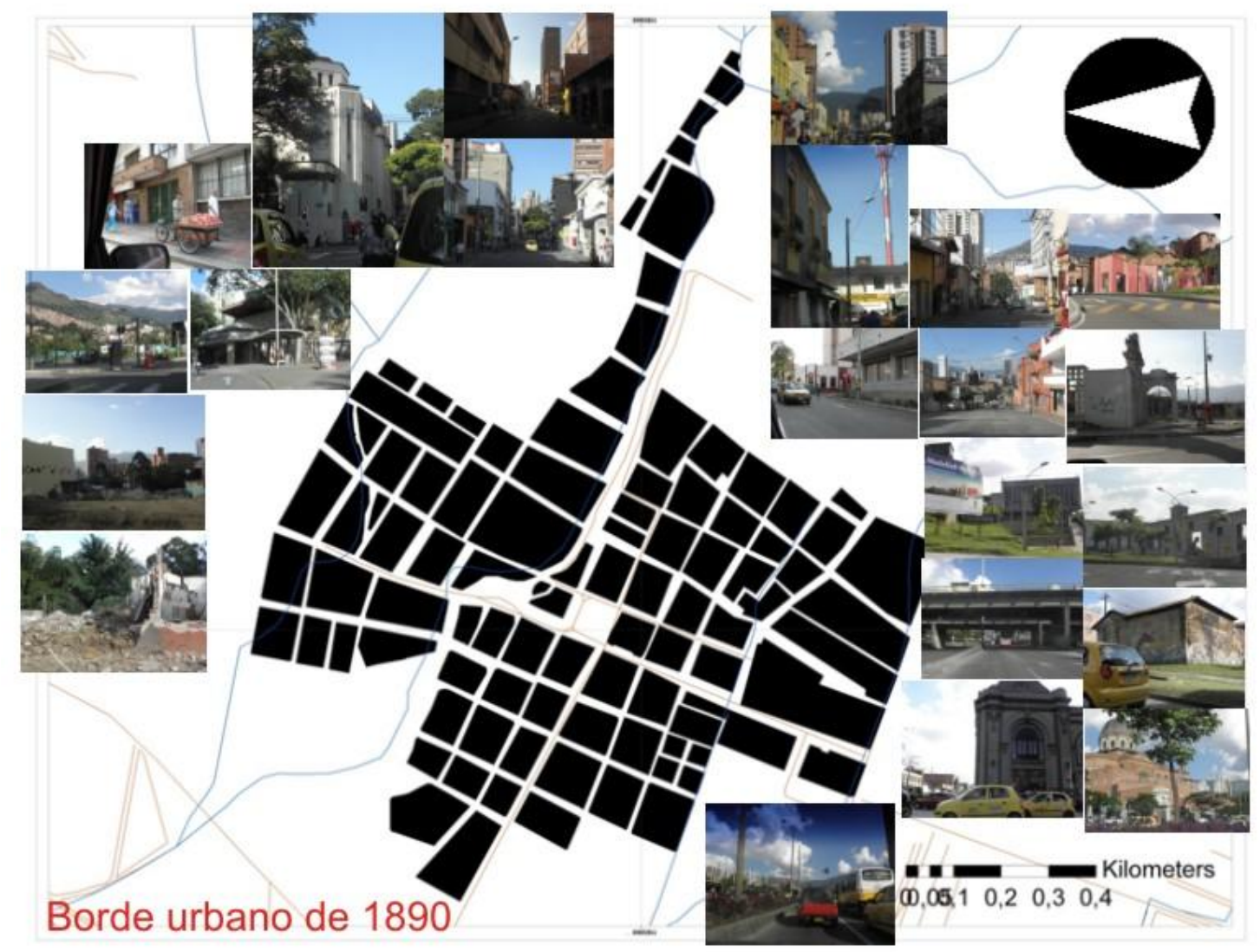

Fuente: ilustración elaborada por el autor.

Con el ejercicio del muestreo regularizado de imágenes se alcanza la identificación de tipologías y diversas formas urbanas asociadas a diferentes "escenarios de comportamiento" (Lynch, 1992); además se logra acceder a un cúmulo de imaginarios urbanos que tienen que ver con el uso e interiorización de los espacios y sus respectivas vivencias, en la intercomunicación ciudadana (Silva, 2003). El análisis de los vínculos entre la forma espacial y el comportamiento espacial, se explicará también desde los controles a la percepción pública que se ejercen desde distintas posiciones ideológicas, tanto del sector público como de algunos sectores privados.

\section{- La fotografía como instrumento para recoger la visión de la realidad social}

El paisaje como organización tecnológica de la memoria colectiva e individual posee un soporte material, huellas que permiten reconocer lo anteriormente aprendido (Ricoeur, 2008). La fotografía, en el caso de la experiencia urbana, es instrumento de representación que facilita el paso del recuerdo en su estado virtual a una presencia actual que trae consigo el hábito (comportamiento ciudadano), la rememoración como economía de esfuerzo. Las fotografías de la ciudad permiten 
también recuperar el sistema de emplazamientos para las principales interacciones de la vida sin tener que comenzar siempre la experiencia de cero.

(...) la imagen fotográfica ha elaborado un nuevo sentido del concepto de información. La fotografía no es sólo una fracción de tiempo, sino de espacio. En un mundo gobernado por imágenes fotográficas, todas las fronteras (encuadre) parecen arbitrarias. Cualquier cosa puede volverse discontinua, cualquier cosa puede separarse de cualquier otra, basta con encuadrar el tema de otra manera. Cualquier cosa puede volverse adyacente de cualquier otra (Sontag, 2005: 32)

Sin embargo, como lo anota Sontag, las fotografías por sí solas son incapaces de explicar nada, y añade: "solamente la narrativa puede permitirnos comprender". Es por esto que para restituir las memorias urbanas se acude a la metáfora del camino, en este caso seguido a través de la historia urbana de Medellín, la cual reconoce unos intervalos o períodos, a través de los cuales los investigadores exploran en el pasado a través de categorías que ofrece la semiótica, disciplina en la que han aportado autores como Paul Ricoeur, Roland Barthes, Richard Sennett y Manuel Delgado, citando los más consultados para esta investigación

La fotografía como instrumento narrativo contribuye en la indagación de las propiedades del medio físico, el espacio urbano, y las transformaciones que éste sufre en el tiempo, facilitando la identificación de los esquemas de memoria (y olvido) colectivo, que se van agregando como capas que al sedimentarse dan forma al paisaje urbano. Esto es posible porque a través de la fotografía se puede identificar la aparición de los elementos que inciden en la transformación icónica de la ciudad, convirtiendo al borde urbano en un vector con improntas específicas que moldea la experiencia de los actores (ciudadanos) en el tiempo y el espacio de la ciudad.

Confrontar las distintas representaciones icónicas obtenidas a través de las fotografías que evidencian las derivas del crecimiento de la ciudad, reconocidas en cada uno de los lapsos de tiempo y fragmentos de espacio que configuran la historia urbana de Medellín, permite la distinción de los bordes de la percepción de un paisaje urbano que ha sido objeto de una experimentación constante, en los que la memoria y el olvido evidencian diversas manipulaciones para la construcción de frágiles identidades (Ricoeur).

Observaremos cómo surgen distintas operaciones urbanas, en las que se suprime, desplaza, reconfigura, impone, celebra y se conmemora, se intimida o se seduce, a quienes de manera expectante, ahora registrados como espectros en las imágenes, han intentado dar sentido al panorama que han observado transformarse. Transformación producto de la imaginación (proyección) o de lo imaginario, donde es posible el encuentro traslapado de situaciones y actores de ayer y de hoy, que existen o no existen: “(...) las fotografías no sólo evidencian lo que hay allí sino lo que un individuo ve, no sólo un registro sino una evaluación del mundo" (Sontag, 2005:98).

Se procura revelar si en los procesos de seducción e intimidación de la resignificación del espacio urbano, los actores cotidianos logran ser despojados de sus propias narraciones (olvido ladino), si evitan o esquivan cierta información (olvido de elusión) y si en algunos casos asumen frente a la resemantización del paisaje urbano comportamientos semipasivos o semiactivos, tal como Paul Ricoeur plantea en el acápite que se ocupa de los excesos del olvido. 
Siguiendo con Ricoeur, el olvido es un acto activo que se opera por negligencia, omisión, imprudencia o imprevisión, todos frutos de la manipulación ideológica, en las que persiste una obsesión que es selectiva, a través de empresas de seducción e intimidación muy palpables en el devenir de las ciudades, en donde quien tiene el poder de ubicar edificios y monumentos intenta imponer su memoria (Delgado, 1998). Por lo tanto, despliega también fronteras de memoria en los que el simulacro de una identidad abarcante y totalitaria plantea que lo que está por fuera vale menos.

Manuel Delgado asegura que si no hay memoria la ciudad no puede existir, ya que los lugares existen porque la memoria los identifica, los nombra y los clasifica, y no sólo eso, les dota de atributos, les asigna un valor. Es por esto que el mismo autor sugiere que lugares de memoria y memoria colectiva no son más que pleonasmos, ya que la memoria se construye socialmente y no puede haber más lugares que en la memoria. Y en relación a todo esto, la reflexión sobre la ciudad en torno a su paisaje como organización tecnológica de la memoria, debe revelar hasta donde los recuerdos que plantea son producto de la impostura o de un proceso culturalmente fidedigno.

\section{CAPÍTULO 3. DESARROLLO DE LA INVESTIGACIÓN}

A continuación se expone el ejercicio de sistematización de los elementos iconográficos que han venido colonizando el espacio urbano de Medellín, herencia de la cultura colonial, como los que han surgido desde la explosión urbana de la ciudad burguesa (republicana), atravesando el desarrollo industrial de las primeras décadas del siglo XX, los procesos de planificación urbana del zoning de la modernidad a mediados de la misma época, hasta llegar al agitado período de la actualidad en los albores del siglo XXI.

Rescatando de la historia la incursión de algunos elementos, tanto en el ensanchamiento de la ciudad o en la contracción de la misma, se pretende revelar el hilo narrativo que ofrece el encadenamiento de los iconos del espacio urbano, definiendo en cada lapso o período las características dominantes del espacio, el tiempo y de los actores (ciudadanos).

Como se anotó antes, para tal efecto se emplea un instrumento matricial (diagrama) que facilita por lo menos dos tipos de lectura, una horizontal que revelaría la dirección y sentido que asumen los bordes de expansión, y la otra vertical (no lineal) que mostraría las diferentes estrategias de colonización que sobre el espacio y el tiempo de la ciudad emprenden diferentes proyectos ideológicos. 


\subsection{Lectura horizontal del proceso de configuración del paisaje urbano de Medellín}

La sistematización de las imágenes que registran el proceso de crecimiento y expansión de la ciudad de Medellín, a partir del momento en que inicia movimientos de agitada transformación, en un lapso de 130 años, considerando los momentos actuales, permite diferenciar algunas etapas, que ya algunos autores han identificado, y que en esta investigación son re-escritos como estratos narrativos del paisaje, comprensión que parte de asumir la ciudad como una superficie discursiva.

La ciudad de Medellín como texto narrativo, comprendido a través de una estrategia narrativa propuesta por esta investigación, reconoce tres grandes momentos en la composición discursiva: el primero entre las últimas dos décadas del siglo XIX y las dos primeras del siglo XX, lapso en el que se presenta una transición entre la herencia colonial y el proyecto burgués de la élite capitalista; el segundo, entre los años 1925 y 1970, periodo en donde la ciudad rompe con cualquier expectativa de crecimiento, pero a su vez, periodo en el que se inician procesos de planificación técnica y la aplicación de instrumentos de ordenación territorial, superados por una realidad acuciante debido a la agitación política del país; y el tercer momento, reúne tres estratos narrativos construidos en los últimos 40 años, que van desde el traslado de las orientaciones del estado en el crecimiento de la ciudad a las dictadas por las prerrogativas del mercado, acentuándose la segregación en la ciudad y la marginalidad de algunos sectores sociales, para llegar finalmente a las apuestas por una ciudad que se suma al parangón internacional.

\subsubsection{Estratos narrativos producidos entre 1870 y 1925}

Para finales del siglo XIX, momento en el que inicia Medellín su acelerado proceso de expansión, el área urbana era de $11^{1} 034.754 \mathrm{~m}^{2}$ (aproximadamente 103 hectáreas), que en el transcurso de tres décadas se incrementa a $8717.849 \mathrm{~m}^{2}$, es decir 872 hectáreas, un índice de $742 \%$ de crecimiento ${ }^{30}$. En cuanto a la población se refiere, en los albores del siglo XX, Medellín contaba con una población de 59.815 habitantes (Suramericana de Seguros, 1988:299) que para 1928, consolidada su vocación industrial, alcanza los 120.044 habitantes (según los registros históricos del DANE ${ }^{31}$ )

Este crecimiento de la ciudad en términos cuantitativos, como los anotados anteriormente, son un indicio claro del proceso notable de transformación, que produce cambios en el paisaje, asunto que puede constatarse a través de las variaciones palpables en las cualidades de los escenarios, en la percepción del tiempo y en las características de los actores. A finales del siglo XIX y las tres primeras décadas del siglo XX, el paisaje de Medellín cambia sus rasgos entre los rezagos de su historia colonial, la transición burguesa y el amplio despliegue de itinerarios que ofrece la agitada actividad comercial.

\footnotetext{
${ }^{30}$ Datos calculados a partir de la información cartográfica antigua, relacionadas con las áreas que ofrece el sistema de información geográfica en el que se basa el Plan de Ordenamiento Territorial de Medellín, 2006.

${ }^{31}$ Departamento Administrativo Nacional de Estadística
} 


\section{- El paisaje del hombre rural urbanizado o rezagos del paisaje colonial}

El borde urbano de la ciudad de finales del siglo XIX se constreñía a una acotada área muy próxima a la plaza mayor, en la que ricos y pobres compartían a pesar de habitar espacios separados, pues la economía demandaba la participación diaria de unos y otros. El comercio se circunscribe a unas cuantas calles de corta extensión, en donde las rutinas aún se definen por el tiempo religioso que vigilaban los templos de la colonia. El control público, como lo expresa Mejía (2000), se ejerce de manera individual.

El espacio urbano ofrece unas perspectivas de dominio horizontal, de calles angostas y casas de uno o dos niveles. El lenguaje de las fachadas, tanto de los edificios públicos y de las casas de los particulares, era austero y modesto. Las escenas de la vida diaria se desarrollaban especialmente al interior de las viviendas, mientras en el exterior, las edificaciones religiosas se destacan en el paisaje por su carácter monumental.

Los contrastes apreciados en los recorridos son pocos y los lugares de referencia se reducen a unos cuantos, muy asociados a la melancolía católica que ofrecen las primeras iglesias, que oficiaban como faros del comportamiento social. La atmósfera del ambiente es predominantemente conventual, debido en gran parte al dominio visual de los templos sobre el paisaje, carácter reforzado por las sobrias costumbres de los habitantes (Mejía, 2000), ancladas por el aislamiento y la incomunicación con el mundo, propias de un centro urbano andino.

Las actividades urbanas están claramente pactadas, tanto en su tipo y cantidad, como en el tiempo y lugar que deben desarrollarse. Por el tamaño de la economía y el número de actores sociales, las actividades urbanas eran limitadas y artesanales, por eso sucedían de manera lineal, sin prisa y con significativas pausas, lo que genera una impresión lenta del paso del tiempo. Además del tiempo religioso, las horas de sol y la ausencia del mismo determinaban las rutinas diarias dentro de esta escenografía colonial.

En las fotografías que logran captar escenas acontecidas entre 1870 y 1890 se aprecia como los nuevos ciudadanos son aquellos que comienzan el tránsito del mundo rural al mundo urbano. Dicho tránsito comienza a reducir el dominio religioso sobre la ciudad, con la introducción de nuevos elementos urbanos de orden capitalista, que como apreciaremos, no alcanzan a modificar sustancialmente la fisonomía del estrato espacio-temporal heredada de la colonia.

La cartografía por su parte muestra cómo hacia la periferia del entorno urbano se localizaban tanto el gueto de los pobres, alejados de la plaza central, como también el lugar para los abandonados o las personas sin hogar, en un deseo característico de la cultura occidental judeo cristiana de segregar aquello que no se quiere tocar, así como también, vivir lejos de los muertos. ${ }^{32}$ De ahí la ubicación periférica de los cementerios tanto de los ricos como de los pobres. Pero por otro lado, es a partir de este período que el borde cobra un nuevo significado, al considerarse como lugar de expansión para la pretensión del nuevo ciudadano burgués, quien ahora compra y vende espacios para preparar la incursión de nuevos componentes como son la catedral, el parque y la plaza de mercado cubierta, elementos que dinamizan el crecimiento de la ciudad en los inicios del siglo XX.

\footnotetext{
32 "Los antiguos temían la cercanía de los muertos y los mantenían a distancia". (Georges Duby, La época de las catedrales, citado por Sennett, 2002:183).
} 
Ilustración 11. Matriz del borde urbano consolidado entre 1870 y 1890

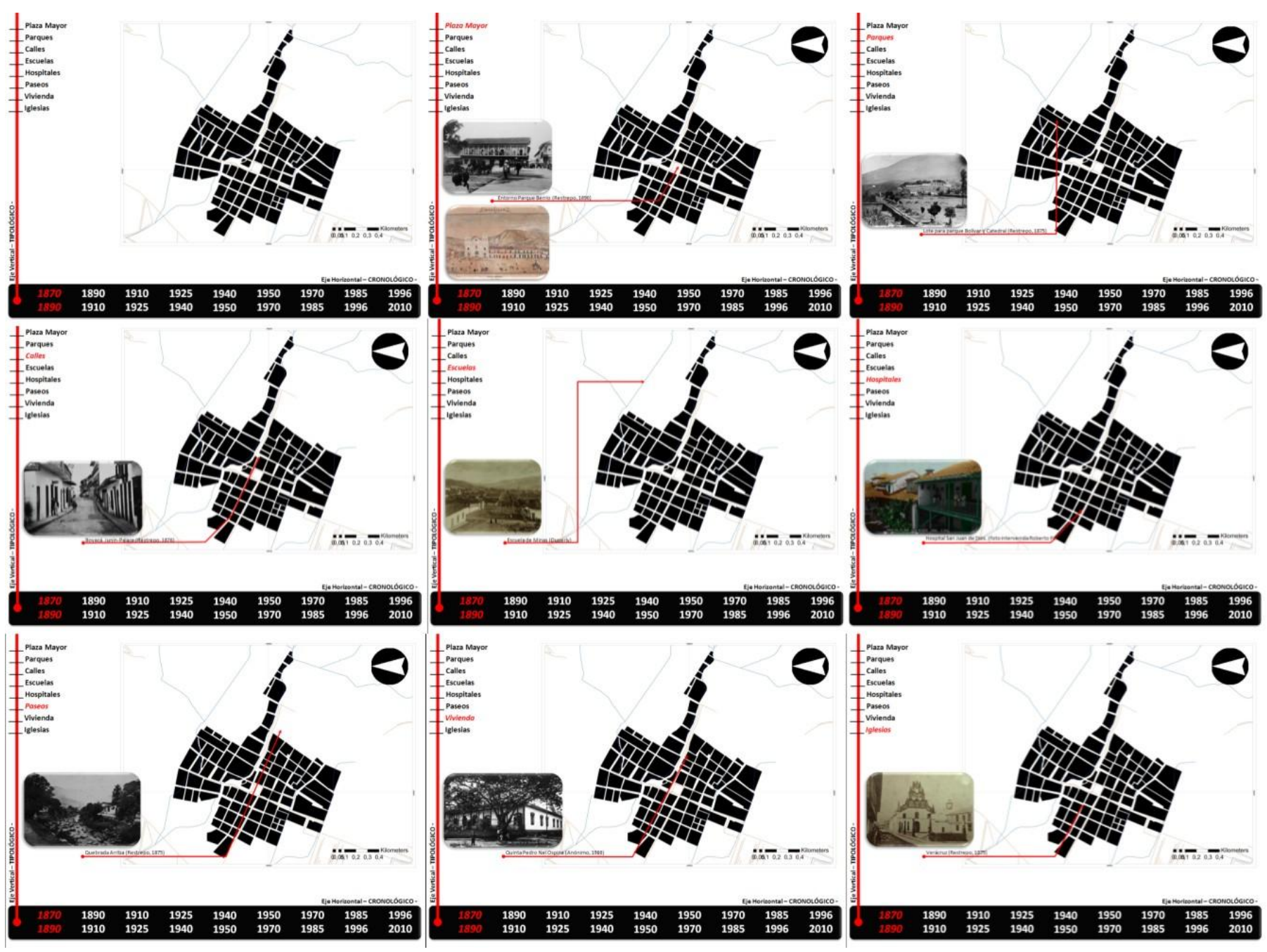

Fuente: ilustración elaborada por el autor. 


\section{- Paisaje ambivalente o de la transición entre lo colonial y lo burgués}

La dinámica urbana iniciada en el contexto de la sociedad colonial, produce los gérmenes de las aspiraciones de convertir la ciudad en un proyecto burgués. Con la agitada actividad comercial, brotan nuevas áreas para el uso y la ampliación de los horarios en función de economías y actividades urbanas, incentivadas además por la llegada de la luz eléctrica. La élite desea renovar sus espacios de habitación, ya que el burgués: “(...) es un hombre abierto al exterior, receptivo a las influencias que confluyen en su ciudad y que proceden de otras ciudades" (Maurice Lombard, Historia de la Francia urbana, citado por Sennett, 2002:200).

Incursionan en el espacio urbano la catedral, el parque y la plaza de mercado cubierta, dentro de un lapso que no supera los diez años. La catedral y el parque surgen en una relación directa, que al materializarse en vecindad valorizan una considerable área que se adosa al norte de la ciudad. Allí, el nuevo ciudadano comienza a introducir nuevas posturas que pasan del sometimiento a la exhibición individual, y de las rutinas dictadas por el trabajo al disfrute del paseo urbano, gracias a las propiedades que adquiere el espacio, entre estas la incorporación del arbolado urbano en el diseño no sólo del parque sino también de las calles.

Se conforma un nuevo centro a partir del núcleo donde tienen lugar las representaciones de lo colonial, ampliando el entorno circunscrito a la plaza central, a un área más extensa, donde comienza a separarse lo civil de lo religioso. Surgen los cafés, los restaurantes y los hoteles que animan los nuevos itinerarios del ciudadano burgués, trasladando las escenas vivificadoras del interior de las viviendas al exterior, haciendo las relaciones sociales más fluidas y desatadas del orden religioso.

Se distingue claramente el ámbito de lo urbano, y el entorno a éste se le domina rural. En el paisaje urbano la incursión de los nuevos elementos contrastan con la herencia colonial, considerada como imagen de una ciudad vieja y atrasada. La élite consideraba esta parte de la ciudad como un estorbo a la idea del progreso burgués, promovido por una generación liberal que encontraba en el espacio urbano el asiento para su proyecto.

Para 1926 en la revista Progreso $^{33}$ se advertía la necesidad de dividir los municipios en zonas, considerando la separación entre las partes rural y urbana. La definición sugerida en ese entonces de la parte urbana merece atención: un centro poblado de calles (Botero, 1996).

(...) los burgueses percibían todo en la ciudad como un obstáculo para el libre desarrollo de las comodidades y placeres (Mejía, 2000:132).

\footnotetext{
${ }^{33}$ La revista Progreso era un medio de difusión de la ideas de la Sociedad de Mejoras Públicas, fundada por la élite en 1899.
} 
Ilustración 12. Localización de los elementos iconográficos del paisaje urbano de 1870-1890 y sus principales rasgos

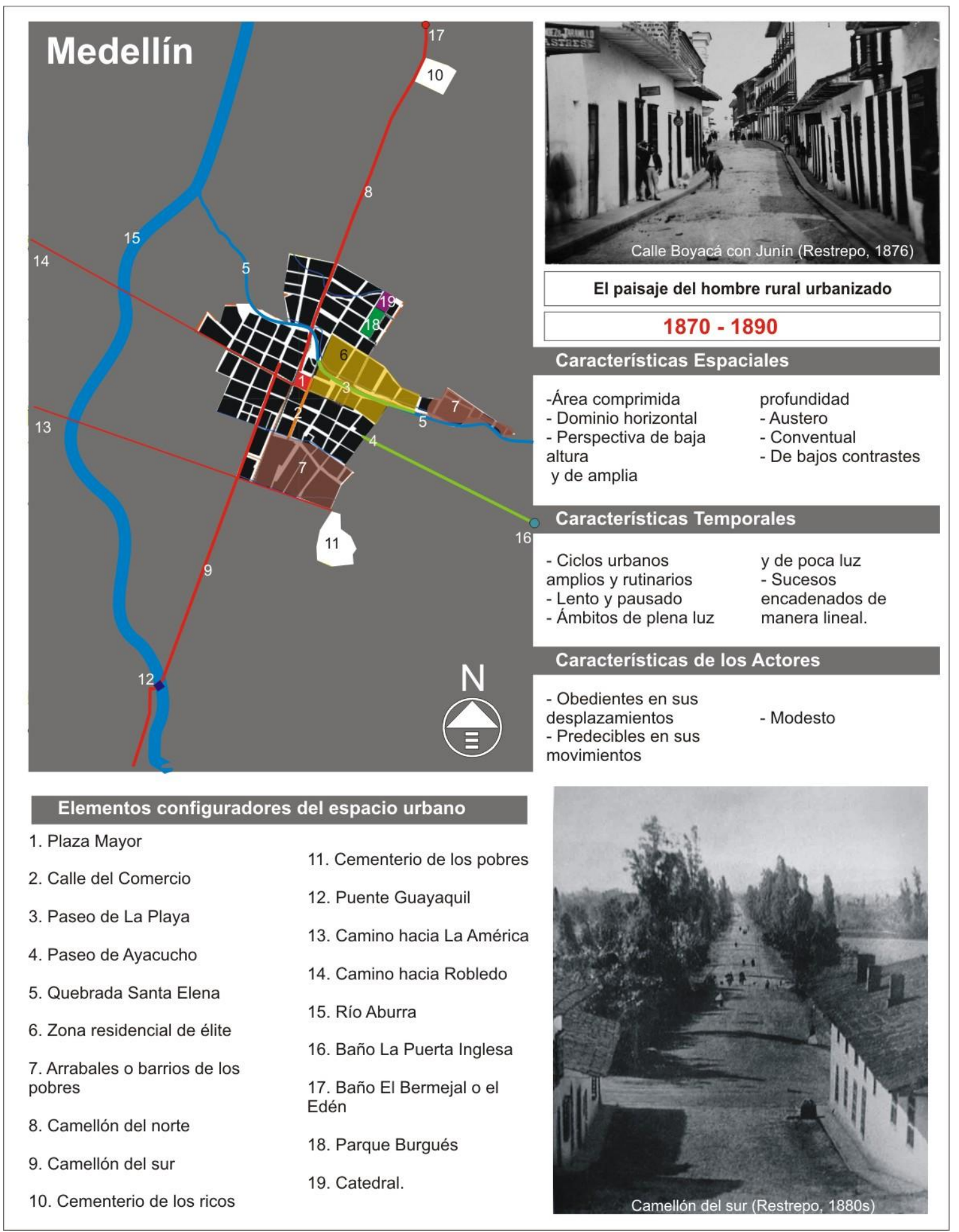

Fuente: ilustración elaborada por el autor con base en la cartografía y fotografía de la época. 
Ilustración 13. Localización de los elementos iconográficos del paisaje urbano de 1890-1910 y sus principales rasgos

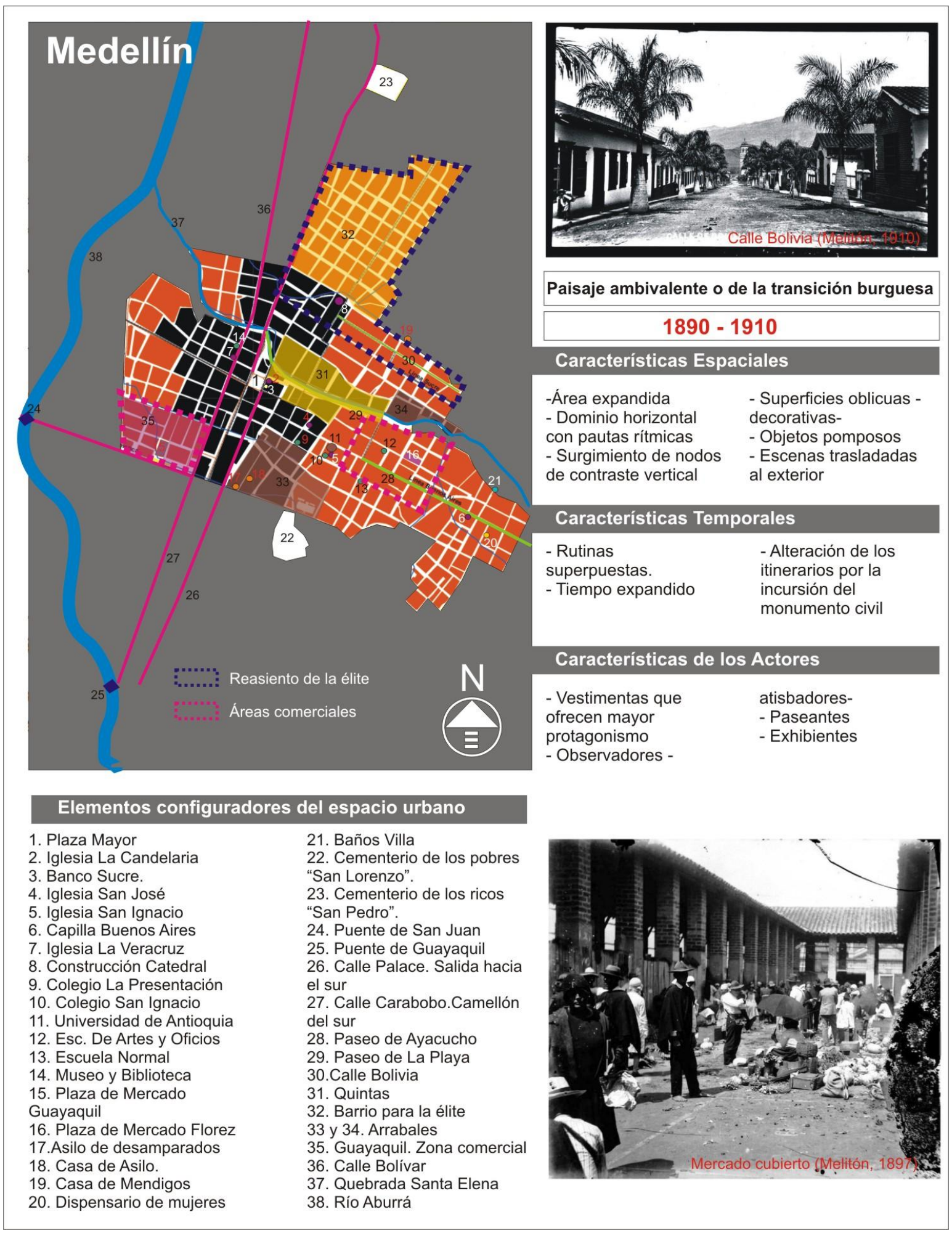

Fuente: ilustración elaborada por el autor con base en la cartografía y fotografía de la época. 
(La Junta central de Higiene) prohíbe establecer caballerizas y corrales públicos en el centro de las poblaciones y ordena a la vez que los que se hallen en tales condiciones serían retirados en un plazo prudencial que fijará el alcalde (Actas del Concejo de Medellín, tomo 352, folio 37, p. 118 citado por Botero, 1996).

A pesar de las incursiones de nuevos componentes en el paisaje, estos de origen capitalista y promovidos por la nueva clase burguesa, el ordenamiento social se resiste al cambio, por tal razón, persisten de cierta manera las costumbres de recluirse temprano en las viviendas, y un rechazo a las actividades sociales nocturnas (Mejía, 2000). Los burgueses ante la falta de sitios de esparcimiento convierten algunos sitios y calles en lugares preferidos para el paseo, incluso algunos sufren cambios de significado y representación, como sucede con la plaza mayor, convertida a finales del siglo XIX en otro parque burgués, y rebautizada con el nombre de un prócer local, Pedro Justo Berrío (Véase la transformación de la plaza mayor al parque Berrío entre las fotos 2 y 9) "Los cambios de los viejos nombres coloniales que tenían las calles, puentes y plazas marca otro signo del cambio que comenzaba a operar sobre el ordenamiento urbano (...)” (Mejía, 2000:202).

Foto 9. Transformación de la plaza mayor en el parque Berrío

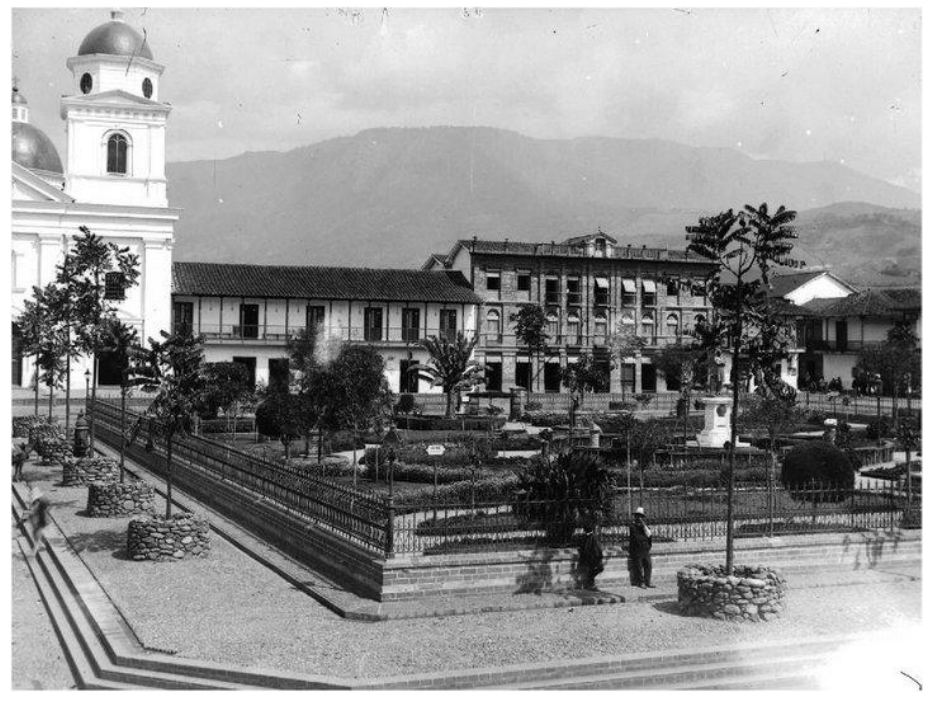

Fuente: Melitón, 1910

El parque y los monumentos civiles aparecen como elementos extraños sobre una estructura de carácter colonial. Los actores urbanos ante estas nuevas incursiones y el texto urbano que viene marcando sus itinerarios los coloca dentro de un debate: respetar lo que se consideraba tradición o abolir y transformar los signos del pasado, para dar paso a un nuevo mapa que instauran las élites burguesa y republicana (Mejía, 2000).

El parque fue el principal elemento que introdujo la burguesía para contrarrestar el sentido religioso que dominaba la ciudad. En éste la gente podía reposar sin estar al interior de sus casas, por esta razón, además de constituirse en un artefacto cultural de disipación en la creciente densidad urbana, se transformó en un espacio que ayudó a liberar el ocio y el tiempo libre de la ciudadanía. 


\section{- Paisajes del comercio, del ocio y de los itinerarios desplegados}

$\mathrm{Al}$ oriente y sur de la ciudad, las nuevas plazas de mercado cubiertas marcaron una ruptura con el sometimiento dominante del tiempo religioso, hasta entonces imperante. Su aparición se debe a que ya se había considerado inconveniente tener un mercado público en la plaza principal, al lado de la iglesia fundacional y de los nuevos edificios comerciales y financieros.

La agitada actividad comercial comenzó a tratar el tiempo como espacio, y éste a su vez se configuró de una forma más flexible, donde el cambio podía ahora tener lugar (Sennet: 2002). Además, el mercado cubierto inició el desplazamiento del área central de la ciudad que representaba la plaza mayor, pues ahora la gente comía, bebía y negociaba en torno a este nuevo lugar. En su interior se generó una nueva distribución y orden en la venta de productos.

Con la incorporación de la plaza de mercado cubierta se produce un artefacto cultural que además de modificar el esquema espacial también, provoca cambios en el temporal. La forma de este espacio facilita que no sólo se emplee para un único uso, sino para múltiples actividades, eso sí asociados al comercio, ya que su localización permite el encuentro de diversos actores, provenientes desde distintas partes de la región, incrementando así la gama de opciones temporales, que por supuesto exige una coordinación social a una mayor escala de la que se daba anteriormente.

Con la plaza de mercado cubierta se asiste a la creación de una nueva zona de gravitación espacial, con tal fuerza que no sólo su entorno más inmediato comienza a girar alrededor de una dinámica de aceleración que sufre el tiempo y el espacio, sino que comienza agregar otras áreas aledañas que se suman a la transformación ${ }^{34}$ que trae consigo el imperio de la economía de capital.

El mercado, que era una actividad semanal subordinada a la festividad religiosa, se ha escindido de ésta para imponer un nuevo ritmo, ahora diario y prácticamente continuo, lo que demanda un mayor desgaste del tiempo y del espacio. Y ahora los actores ciudadanos se encuentran en una escenografía que pone en relieve más el presente que el pasado, pues el espacio económico hace una utilización oportunista del tiempo a diferencia del lugar religioso, en el cual el creyente se siente en un perpetuo peregrinaje (Sennett, 2002).

La compartimentación y especialización del espacio, así como el uso intensivo del tiempo, requiere la incorporación de nuevos roles en la escena social. El productor, quien era antes el mismo vendedor, se ve ahora reemplazado en este último papel por otros, quienes están dispuestos atender la incesante actividad comercial. Y entre productores y vendedores aparecen los intermediarios, y con estos el requerimiento de espacios de almacenaje, así como zonas de descarga y parqueo para la época de carros tirados por bestias, que en pocos años serían reemplazados por los primeros coches a motor.

\footnotetext{
34 "La Plaza de Mercado era la punta de lanza de un proyecto urbanizador que ya tenía pensado, desde finales del siglo XIX, la ubicación de la estación terminal de Ferrocarril de Antioquia, la estación terminal del Ferrocarril de Amagá, el matadero, el frontón Jai Lai (Hipódromo), la Plaza de Feria de Animales, edificios, comercios, industrias y urbanizaciones -Los Libertadores y Barrio Colón-, que convirtieron las zonas pantanosas del sur de Medellín, en uno de los terrenos más apetecidos de la ciudad" (González, 2007).
} 
Se amplía así el espectro de actores citadinos, los cuales a su vez demandan servicios de alimentación, entretenimiento y hospedaje. Es por esto que junto a la plaza de mercado se acondicionan hoteles, inquilinatos, ${ }^{35}$ cafés y cabarets. Es así como en la ciudad se comienzan a entremezclar actividades sagradas y profanas dentro de un tejido urbano que se ha expandido de tal manera que los actores diariamente atraviesen umbrales que separan ámbitos distintos y en los que asumen diferentes conductas, en este caso unas dominadas por lo religioso y en las otras por lo económico.

Foto 10. Mercado Cubierto, 1931

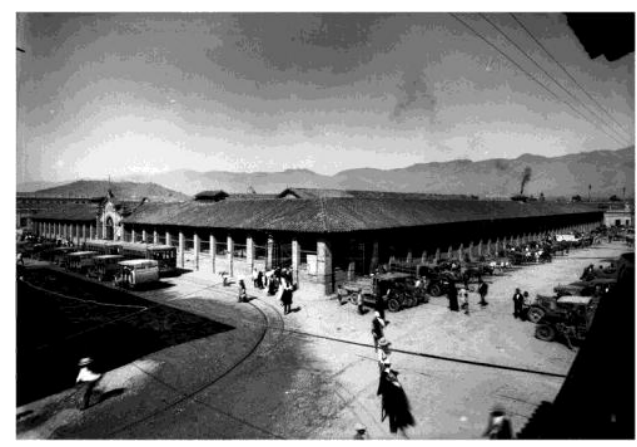

Fuente: Mejía, 1931
Foto 11. Alrededores de la plaza cubierta de mercado, sector Guayaquil, 1920s

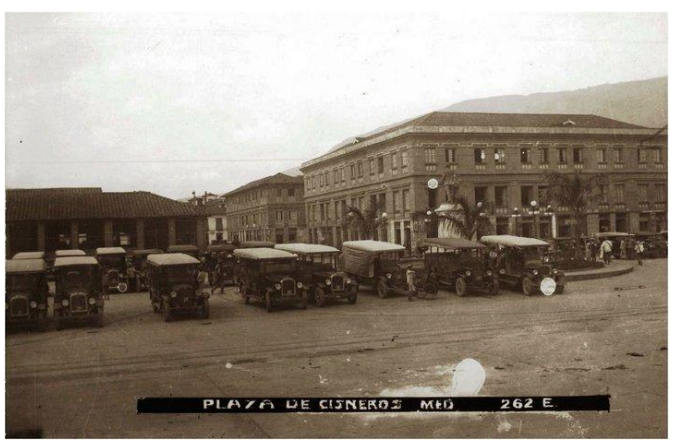

Fuente: Escovar, 1920s

Ese espacio sagrado, protegido de las influencias externas gracias a los objetos mágicos venerados en los templos católicos, en el que las actividades se despliegan en un tiempo lento, pero constante y seguro, contrasta con el espacio y el tiempo de la economía capitalista, que arroja a los actores urbanos a la incertidumbre

Foto 12. Teatro Bolívar, 1922

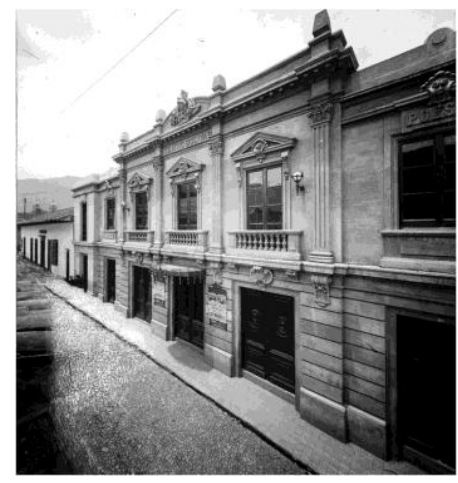

Fuente: Melitón, 1922
Foto 13. Público en el teatro Bolívar, 1935

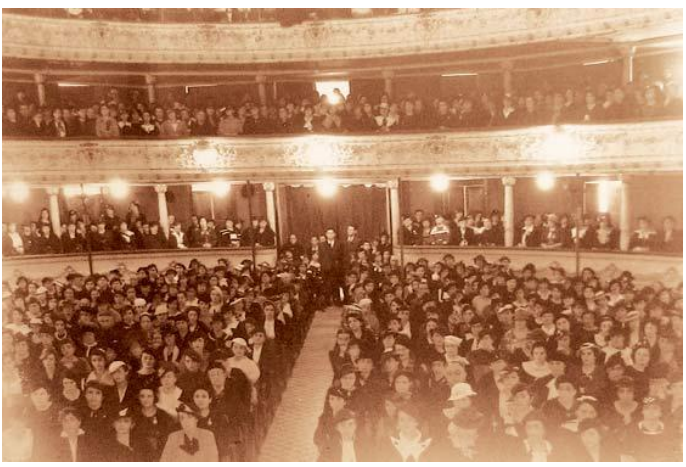

Fuente: Periódico El Espectador (1935). Fotografía de Melitón

\footnotetext{
${ }^{35}$ Los inquilinatos en general son grandes casonas de la época colonial, acondicionados para dar albergue barato tanto a los viajeros que llegaban por razones comerciales a la ciudad, como a quienes de manera constante habitaban en ella y no hallaban una oferta de vivienda distinta que se ajustara a sus condiciones económicas.
} 
Pero si la plaza de mercado cubierta amplía el espacio y el tiempo económico sobre la ciudad, contrarrestando el dominio del espacio y el tiempo religiosos, el club social, los teatros y los cafés desdemonizan la noche (Mejía, 2000), ampliando los itinerarios tanto en horarios como en lugares. En la motivación burguesa no existe ni quietud ni estancamiento, mucho menos modestia, además introduce el concepto de belleza, éste, totalmente externo al ser (Berman, 1991).

\subsubsection{Estratos narrativos producidos entre 1925 y 1970}

El área urbana de Medellín se incrementa en un 548\% entre 1925 y 1970, pasando de 871 hectáreas a 5653 hectáreas, aproximadamente. Durante este mismo periodo la población que era de 120.044 habitantes, supera ya el millón llegada la década de $1970^{36}$. Dentro de este periodo la ciudad da un salto franco hacia el occidente de la ciudad, gracias a la canalización del río de Medellín o Aburrá, lo que permitió transformar esta parte de la ciudad caracterizada por su condición cenagosa e insalubre, en un área apta para el emprendimiento de proyectos de urbanización.

El área de dominio de lo urbano adquiere tan amplia magnitud en tan corto tiempo, que diferentes discursos y planteamientos ideológicos intentaron darle un orden que guiara su crecimiento desaforado. Pero no sólo el paisaje urbano se transformó por el movimiento de expansión de la ciudad en diferentes direcciones, también sucedió porque una fuerza de contracción al interior de la ciudad cambia las cualidades de su núcleo central, lugar disputado por varios tipos de representación simbólica. Durante este lapso se agregan tres estratos narrativos en la ciudad, uno gobernado por la moral cívica que define el espacio y el tiempo de las grandes masas, otro por la intención de escape de las clases altas, y otro por el deseo corporativo de marcar la silueta urbana.

\section{- Paisaje de la disciplina y el orden moral cívico}

Con la llegada del ferrocarril a la ciudad en la década de 1910, el área de expansión se dispara, incorporando áreas que fueron destinadas principalmente a la constitución de nuevos barrios, en su gran mayoría para los obreros de las empresas semifabriles y las fabriles que inician con denotado empuje. Y es la misma burguesía, con las primeras empresas urbanizadoras, que adquiere fincas en la periferia de la ciudad para abrir calles y edificar casas para la nueva clase obrera.

La apertura de estos nuevos espacios dio oportunidad para convertirlos en lugares donde la gente pudiera desplazarse y respirar libremente. Es a partir de esta expansión de la ciudad que ingenieros y médicos plantean un proyecto de ciudad que en gran medida sustituye la moral religiosa por una de carácter más cívica. Para tal propósito, la regulación normativa tuvo un gran efecto, ya que desde finales del siglo XIX se reglamentó, por ejemplo, el ancho de las calles. Los proyectos de urbanización adquieren mayor complejidad, definiendo jerarquías viales, y definiendo áreas para la localización de equipamientos especiales, que facilitaran el control de la higiene.

\footnotetext{
${ }^{36}$ Según el censo efectuado por el DANE en 1973, Medellín contaba con 1'077.252 habitantes.
} 
Ilustración 14. Localización de los elementos iconográficos del paisaje urbano de 1910-1925 y sus principales rasgos
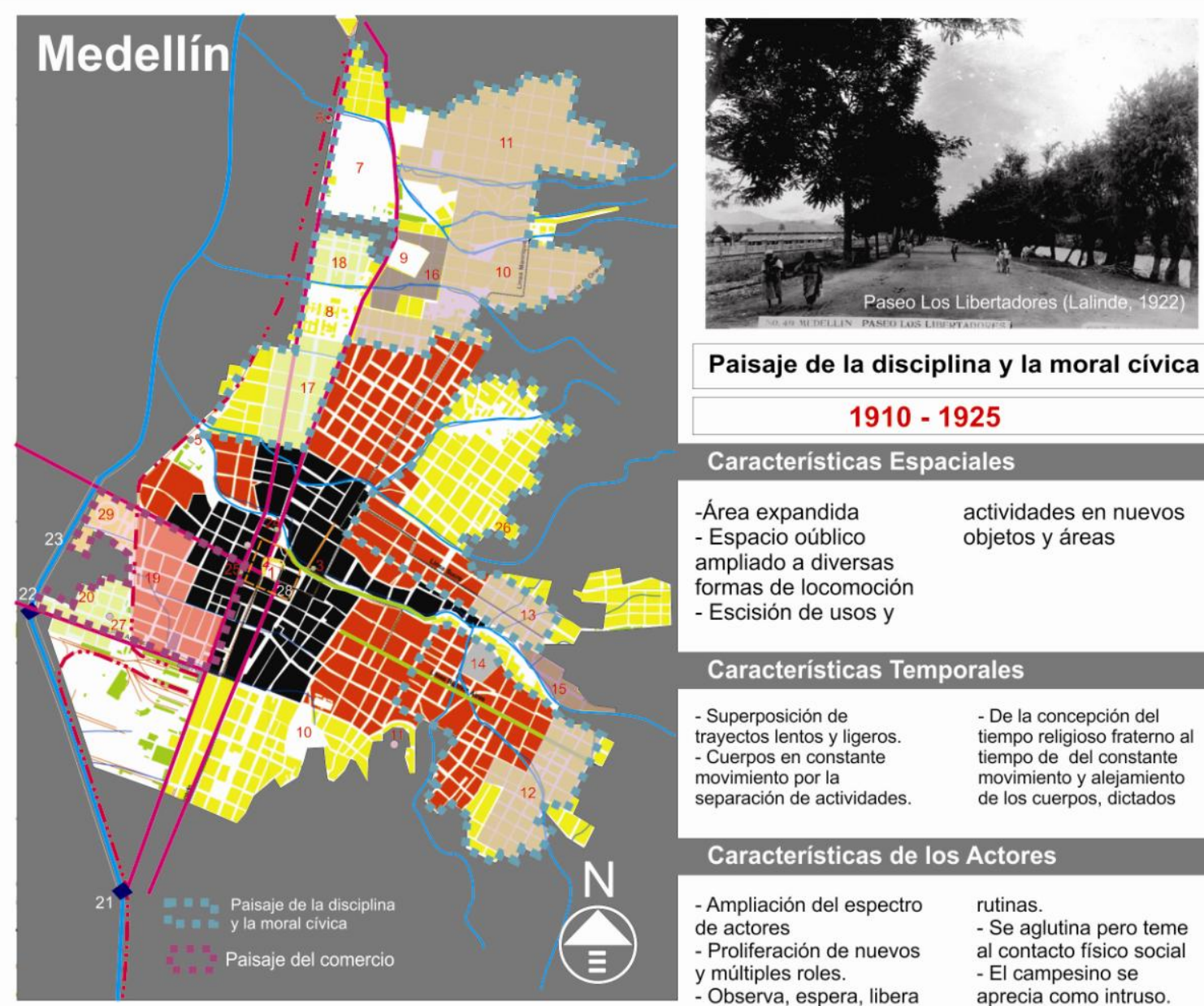

Paisaje de la disciplina y la moral cívica

$$
1910 \text { - } 1925
$$

\section{Características Espaciales}

-Área expandida

actividades en nuevos

- Espacio oúblico objetos y áreas

ampliado a diversas

formas de locomoción

- Escisión de usos y

\section{Caracteristicas Temporales}

- Superposición de trayectos lentos y ligeros. - Cuerpos en constante movimiento por la separación de actividades.
- De la concepción del tiempo religioso fraterno al tiempo de del constante movimiento y alejamiento de los cuerpos, dictados

\section{Elementos configuradores del espacio urbano}

1. Plaza Mayor

2. Incendio de 1917 en el parque Berrio.

3. Teatro Junín

4. Estación Ferrocarriles de Antioquia.

5. Estación Villa

6. Estación El Bosque.

7. Bosque de La

Independencia.

8. Hospital San Vicente de Paul

9. Cementerio San Pedro (de

los ricos)

10. Cementerio San Lorenzo (de los pobres)

$11,12,13$ y 14 . Barrios Obreros

14. Fabrica de Tejidos.

15. El arrabal de La Toma

16. Zona de cabarets

17, 18 y 20 Nuevas áreas residenciales.
19. Zona comercial

21. Puente de Guayaquil (Hacia los corregimientos del sur

22. Puente de San Juan (Hacia los corregimientos del occidente)

23. Paseos Los Libertadores y Los Conquistadores (Paralelos al rio)

24. Palacio Departamental

25. Palacio Nacional

26. Cárcel La Ladera

27. Iglesia Sagrado Corazón

28. Reformas a edificios de carácter corporativo en torno al parque Berrio (antigua Plaza

Mayor)

29. Feria de animales

\section{Caracteristicas de los Actores}

\section{- Ampliación del espectro \\ rutinas} de actores

- Proliferación de nuevos y múltiples roles.

- Observa, espera, libera su movimiento a nuevas

- Se aglutina pero teme al contacto físico social - El campesino se aprecia como intruso.

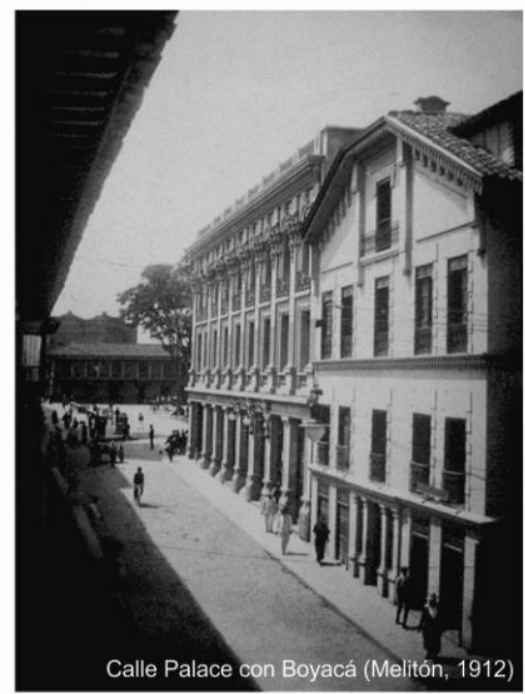

Fuente: ilustración elaborada por el autor con base en la cartografía y fotografía de la época. 
El urbanismo de esta época incorpora la noción de los pulmones urbanos adecuando áreas que permitieran la disipación de la energía que significaba el aumento de la densidad poblacional, como sucede con la tecnología social del bosque urbano. ${ }^{37}$ La ampliación del espacio a través de estos nuevos bordes, además de incluir los artefactos para garantizar la higiene, procura mantener el control del comportamiento de las masas a través de artefactos culturales que mantuvieran en orden las conductas de los individuos

Foto 14. Bosque de La Independencia

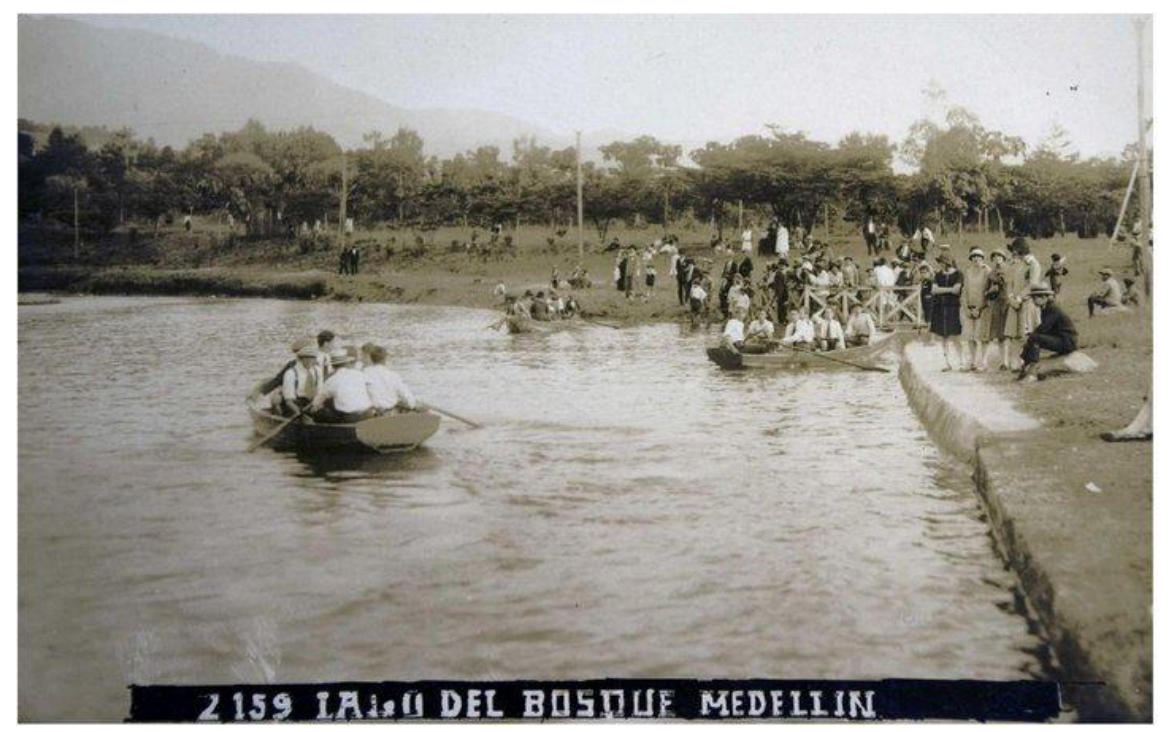

Fuente: Escovar, ca. 1920

La localización estratégica de los primeros hospitales (que superan la noción de los centros de asistencia y caridad cristiana, propios de la colonia), las escuelas, e incluso la cárcel, que ha salido de la zona núcleo de la ciudad, demuestra que controlar y vigilar se hacía cada vez más difícil, por lo tanto, dicho control ya no se ejerce directamente sobre los individuos sino sobre los lugares.

El concepto de barrio comienza a ser incorporado en el lenguaje habitual, aunque los habitantes todavía se sigan refiriendo más a la parroquia en el sector donde residen, esto en gran parte a que el templo católico continúa siendo el germen de la colonización de cada nueva área que se anexa a la ciudad. En relación a esto anota Mejía (2000): “(...) los barrios solo adquirieron presencia en el momento en el que el ordenamiento burgués pudo romper con éxito la unión estrecha que había mantenido el espacio urbano con las prácticas mágico religiosas (...)”.

\footnotetext{
37 “ $(. .$.$) de lo que se trata por parte del proyectista es de calmar la excitación producida por la vida urbana, y$ hacerlo dotando al usuario de los espacios colectivos de imágenes estructuradoras, tanto en el plano afectivo como en el cognitivo y perceptual, imágenes cuya función sería, en última instancia, la de encarnar valores y simplificar el mundo, eliminando lo irrelevante en cada caso y representando las expectativas" (Rapoport citado por Delgado, 2010:91).
} 
Ilustración 15. Los primeros barrios construidos en las áreas de expansión del nororiente de Medellín

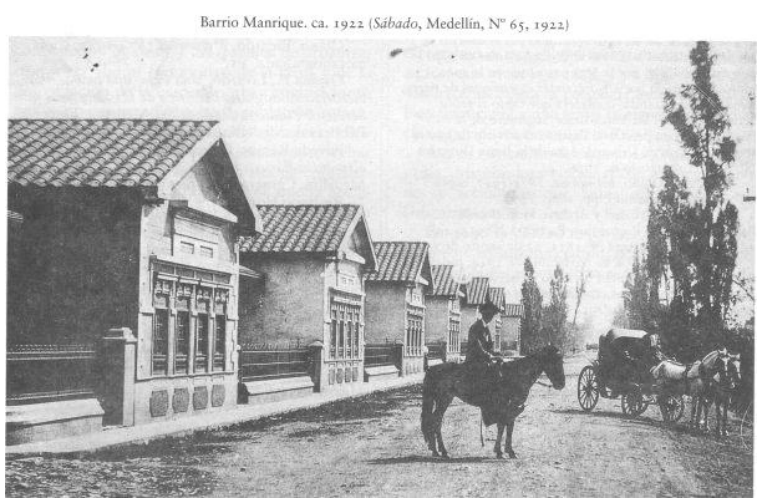

Fuente: revista Sábado, Medellín, ca.1922.

Foto 16. Colegio San José, localizado al centrooriente

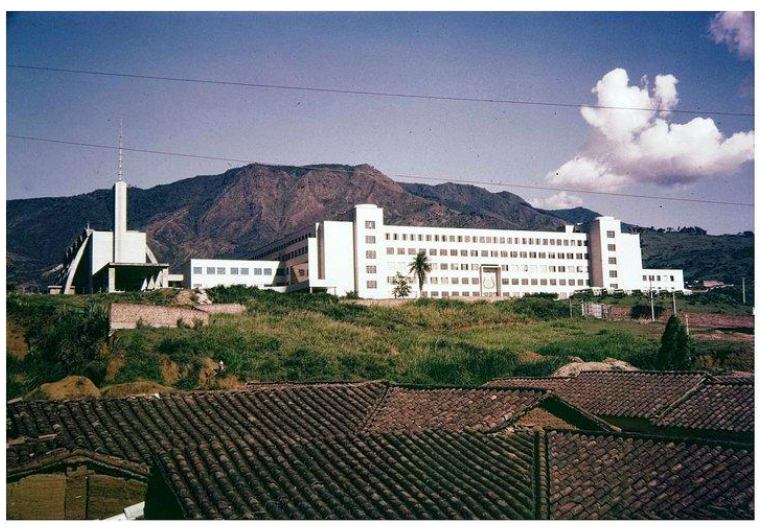

Fuente: Carvajal, 1959
Foto 15. Escuela Modelo

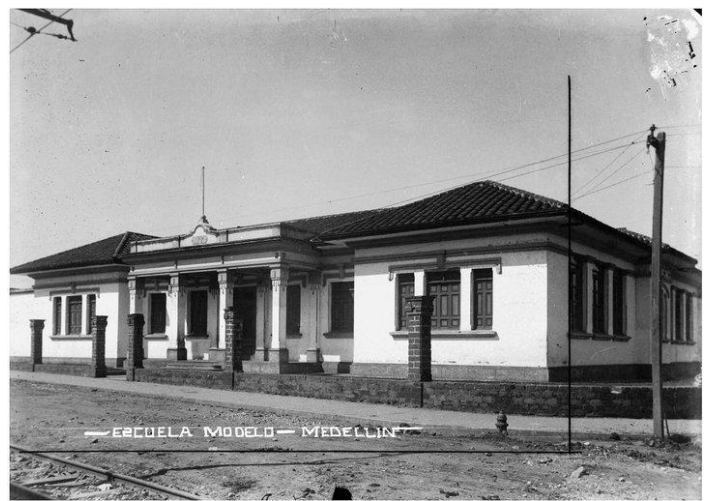

Fuente: Melitón, 1924

Foto 17. Construcción del Hospital Pablo Tobón Uribe

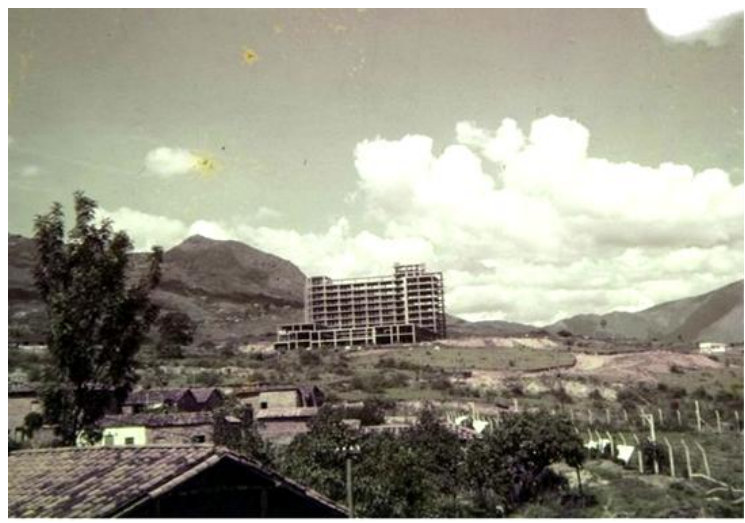

Fuente: Carvajal, 1950s

Foto 18. Hospital San Vicente de Paul

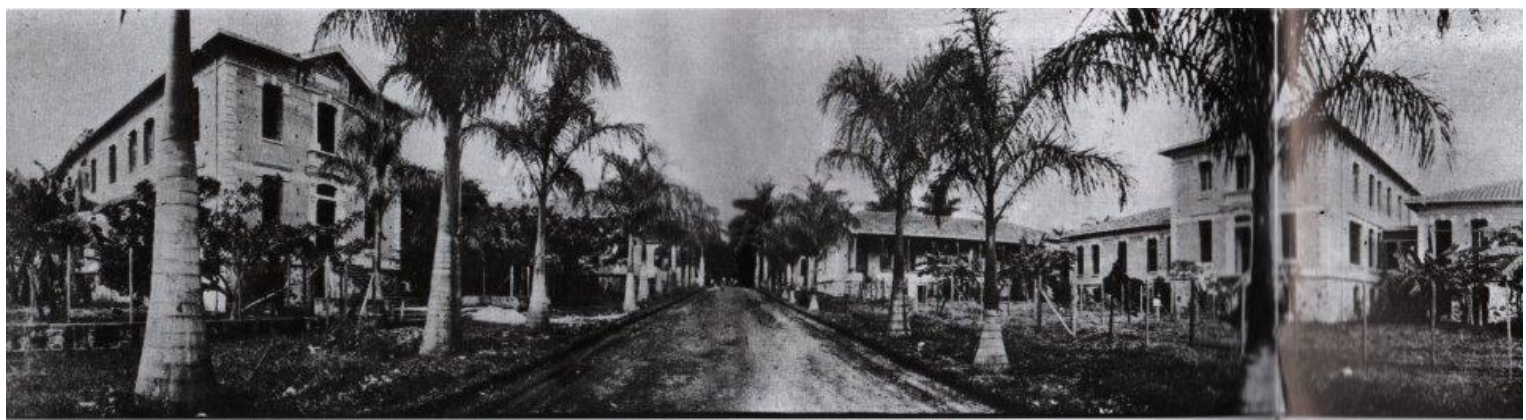

Fuente: Melitón, 1920s 
Se suma a los dispositivos de colonización de áreas periféricas el monumento religioso, tanto para valorizar unas tierras, ${ }^{38}$ hasta entonces desprovistas de significado urbano, como para acudir al imaginario colectivo sobre algunos referentes que aseguran comportamientos que se desean por parte del poder político, económico y religioso, y que se deben mantener dentro del orden social requerido, ahora denominado en la ciudad, civismo.

Los nuevos ciudadanos, los proletarios de las industrias y los asalariados de las empresas comerciales y bancarias, son tratados como escolares en un ambiente urbano manipulado por la instauración de una identidad común. Ante el ya caduco texto colonial que se ceñía con predominio sobre la villa, es necesaria una nueva liturgia urbana, que se soporta en la organización del espacio y de las rutinas ${ }^{39}$ que se deben seguir para garantizar la producción de capital.

\section{- Paisaje de escape}

Es el resultado del desplazamiento clasista, en el que se procura una configuración espacial que facilite la evasión del centro urbano. Con la aparición de la vena urbana (avenidas urbanas), la calle se convierte en un medio de escape, perdiendo así el vínculo que tenían con el diseño de los edificios, constituyéndose en un simple corredor para la circulación.

Con el incremento significativo de la población, la clase social privilegiada observa con asombro cómo es ahora rodeada por la clase obrera que diariamente asiste a sus fábricas y empresas. Ante el miedo de tocar tan cercana realidad de las clases medias y bajas, los padres de la ciudad y sus

38 “(...) muchos años después de haberse recibido las calles aun se seguía urbanizando el barrio de El Salvador, y se ofrecía en la prensa de 1929 de la siguiente manera: El más elegante y de mejor clima de la ciudad, con avenidas, carreteras, pasajes y un parque de más de 14.000 varas al pie del monumento. Cuenta con todos los servicios municipales, con tejar, piedras y tierras de boñiga y arena. Planos modernos para las construcciones. El plano general puede verse en el Almacén Británico, en la oficina del Centro de Ingenieros y en la de Clímaco Velásquez, en el edificio Olano, en el Barrio, en casa de don Antonio J. López" (González, 2007).

${ }^{39}$ La Sociedad de Mejoras Públicas, conformada por comerciantes y hombres de negocios, entre ellos los principales urbanizadores de la época, instauraron un proyecto económico y social que logró obtener el apoyo de todos los demás grupos sociales. Su propósito explícito era la creación de un espíritu cívico, y en tal sentido, promovió campañas, como el ciudadano de oro para quienes adelantaban obras de urbanización y arborización, también premios al mejor obrero del municipio (1935), la casa obrera mejor arreglada y la vitrina mejor diseñada. También instauró Juntas de vecinos y centros cívicos, todo con el ánimo de la internalización de una identidad común y homogeneizante. Todos estos aspectos son abordados por Fernando Botero (1996) 
familias emprenden un reasentamiento al occidente de la ciudad, ahora adecuado por la canalización del río y las quebradas, y acercado por el tranvía y las carreteras.

Foto 19. Trazado del barrio Belén, sur- Foto 20. Trazado del barrio Laureles, centro-occidente de occidente de Medellín

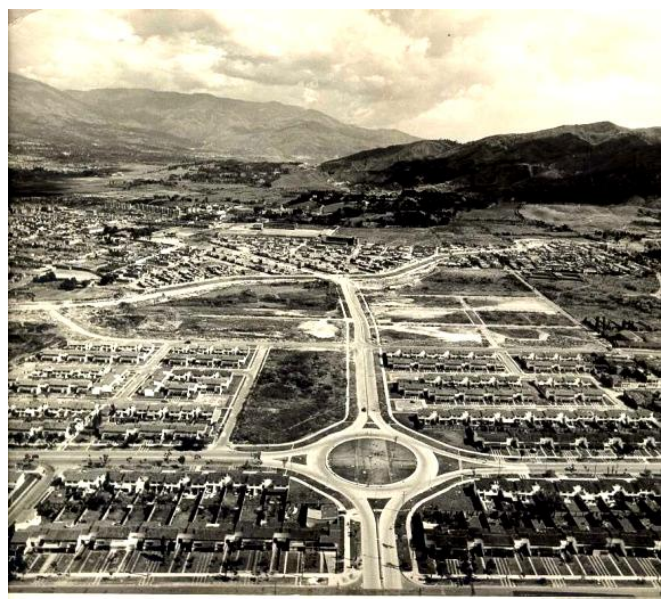

Fuente: Carvajal, 1975.

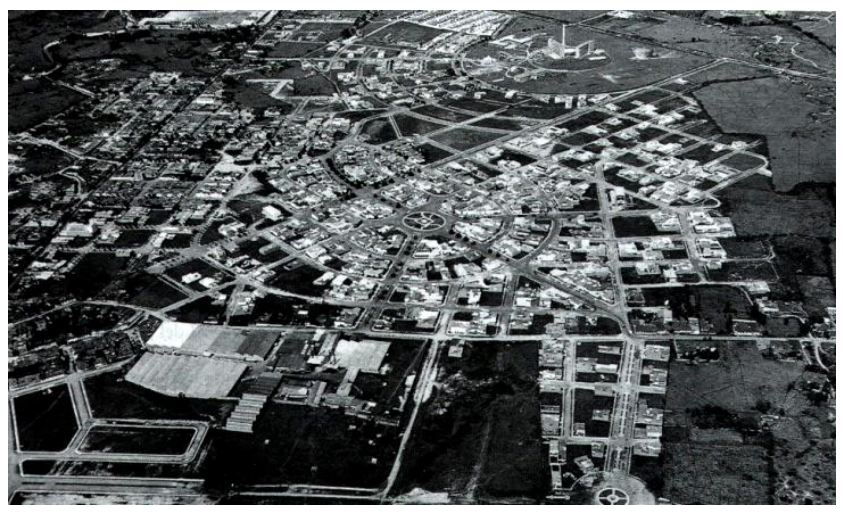

Fuente: Carvajal, 1953.

El barrio burgués, en los sectores de Laureles y Bolivariana, se acoge a los planteamientos de la garden towns, ya que su configuración facilita la evasión onírica que las clases pudientes hacen del panorama agitado del escenario urbano en el centro de la ciudad. El paisaje de estos barrios burgueses intensifica la imagen pictórica, la seducción del movimiento constante, para protegerse del contacto con el otro. Los cuerpos ahora yacen pasivos en actos de contemplación de imágenes armoniosas, mientras el tiempo convulsionado de lo urbano, de las muchedumbres, ha sido alejado de la escena que ha preparado el urbanista, para que todo parezca estar en la posición de un retrato perfecto, congelado en el tiempo.

Pero este tipo de paisaje aparece en el interior mismo del núcleo central expandido, en los paseos urbanos, por donde la multitud fluye atrapada en la circulación y atraída por el resplandor de las fachadas comerciales. El paseo de la calle Junín se convierte en una escena típica, donde los ciudadanos cruzan una pasarela para ir y venir, para ver y ser visto entre el Teatro Europa y La Catedral. Se configura así un corredor donde se moldea la imagen del caballero y la dama, así como la persuasión o la idea del amor entre estos. 
Foto 21. Paseo de la calle Junín. Pasarela en la que se moldea la idea de la dama y el caballero burgués

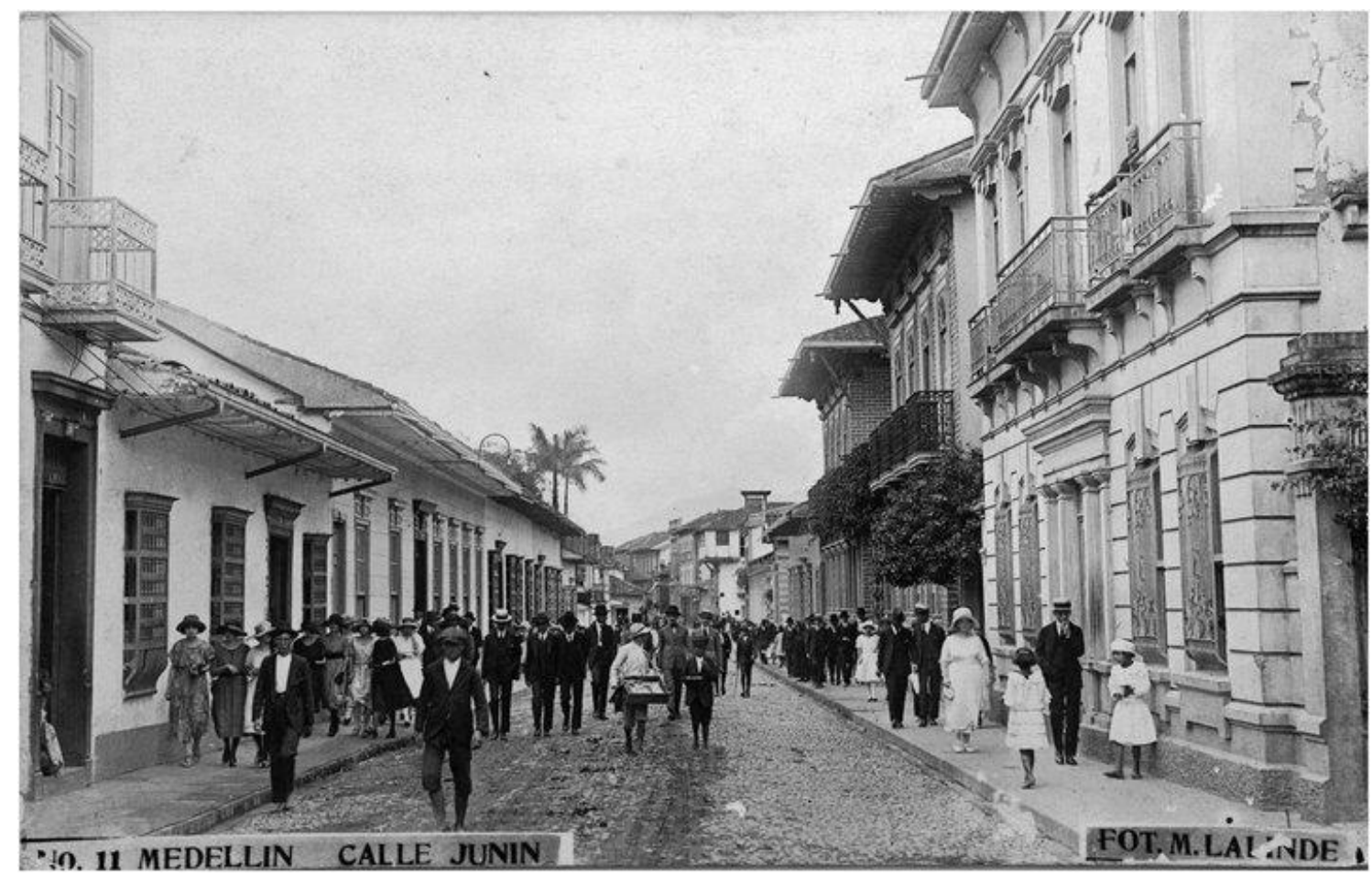

Fuente: Lalinde, 1920

Foto 22. Man chatting with woman standing in window. Medellín

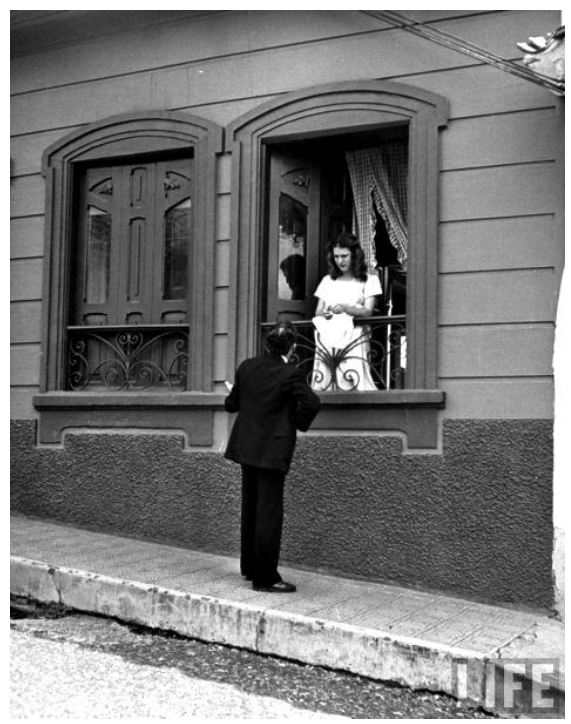

Fuente: Dmitri Kessel, ca. 1947
Foto 23. Habitantes de la calle junto a una vitrina comercial. Centro de Medellín

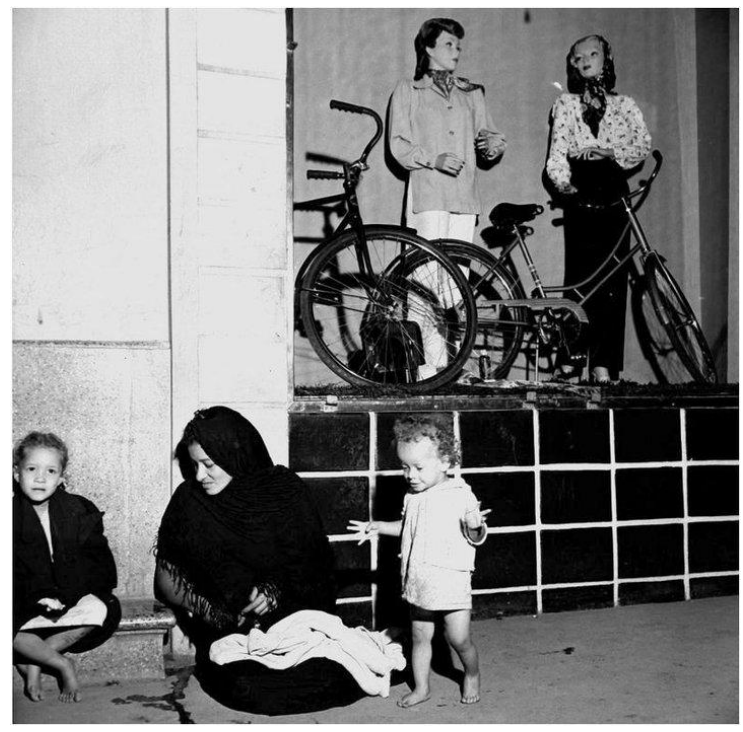

Fuente: Carvajal, ca. 1950. 
Pero ese amor moderno que nace en el paseo o en el bulevar, tal como Berman (1991) lo revela, pierde su inocencia cuando los exiliados e inmigrantes de otros estratos narrativos, como son los pobres, hacen aparición. Los enamorados temen ser sacados de su aislamiento amoroso, y enfrentan un nuevo debate: o confrontan las escenas de la inequidad y las promesas rotas del bienestar común, o escapan a un paisaje pictórico y onírico, donde resulte válido no tocar y palpar las heridas que se abren sobre la ciudad.

\section{- Paisaje intimidante y apabullante}

Se caracteriza por la erección de objetos en el espacio urbano destacados por sus dimensiones contrastantes con los rasgos dominantes del entorno. La pretensión es crear un efecto dramático de la ostentación del poder económico y corporativo, involucrando a los citadinos en una experiencia teatral. Esta transformación del paisaje urbano tiene una acción denodada sobre la zona núcleo, empleando tácticas de borrado y reescritura sobre los iconos que caracterizaban este entorno urbano.

La especulación por el valor del suelo en la zona núcleo o central de la ciudad, en pleno auge de la economía de su actividad industrial, tiende un manto de pérdida de valor sobre los iconos erguidos en épocas recientes, que compiten con las campañas de institución de una nueva identidad frágil en lo político y en lo social. La pretensión de subrayar sobre la ciudad un nuevo culto ante el poder corporativo, da como resultado un cambio sobre la silueta urbana (skyline) con sendos edificios en altura.

El espacio toma rasgos de una escenografía apabullante, especialmente en la zona núcleo de la ciudad, así sea pasando por encima de las huellas que daban coherencia a las rutinas de los actores diarios en la escena urbana, obligándolos a la restitución de la memoria (la rememoración de Ricoeur) dentro de una trama con sentido en un tiempo narrado a asumir posiciones como la del vagabundo y el errante, ya que las nuevas proporciones del espacio urbano en relación a su cuerpo lo dejan perplejo, incluso en parálisis, ya que al citadino se le dificulta recrear los recuerdos por el enmascaramiento acontecido en el entorno.

La transformación del paisaje entre las décadas de los cuarenta hasta los setenta del siglo XX es la instauración o dominio del proyecto moderno. Éste logra convertir el espacio en una especie de arroyo, en donde las personas luchan con su cuerpo para salvarse de un conglomerado de gentes que corren a prisa en todas direcciones. El nuevo borde que configura este nuevo estrato en la ciudad no reconoce límites espaciales o temporales, y se apresura a ampliar y colonizar su dominio sobre todo el territorio. 
Foto 24. Demolición del teatro Bolívar

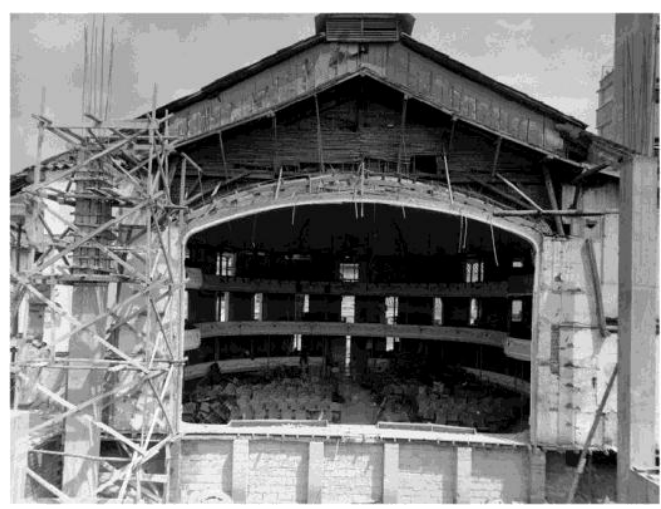

Fuente: Carvajal, 1954
Foto 25. Demolición del Teatro Junín y Hotel Europa

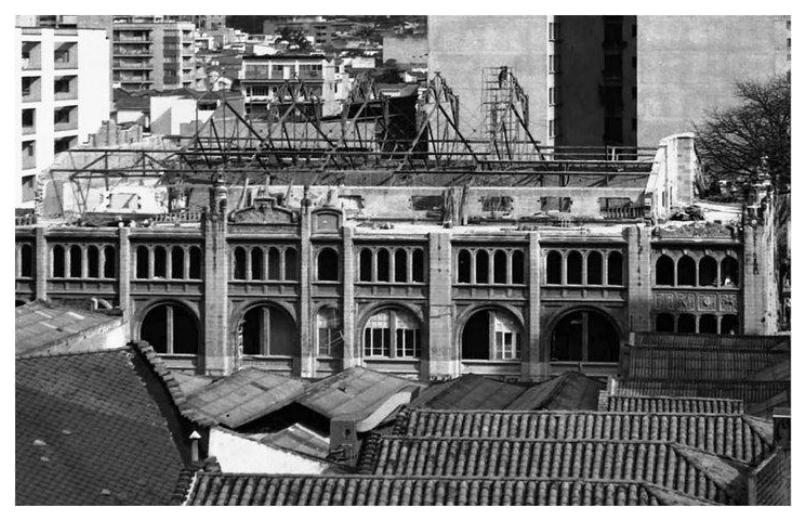

Fuente: Carvajal, 1968
Foto 26. Incendio del edificio Gutiérrez

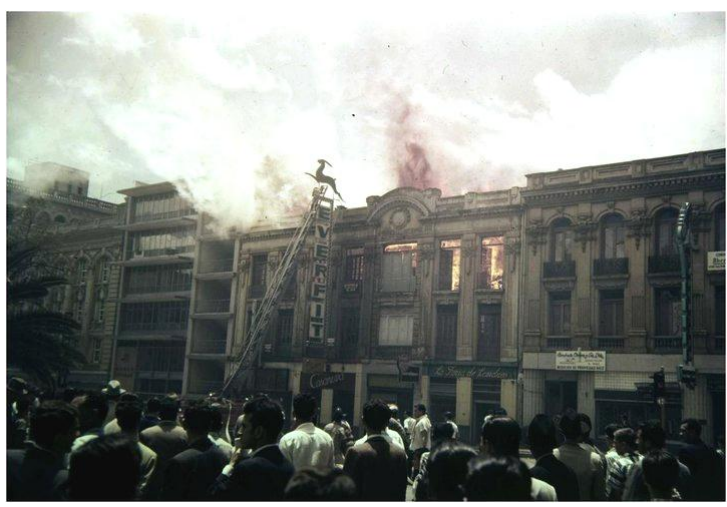

Fuente: Carvajal, 1959
Foto 27. Incendio del edificio Gutiérrez (2)

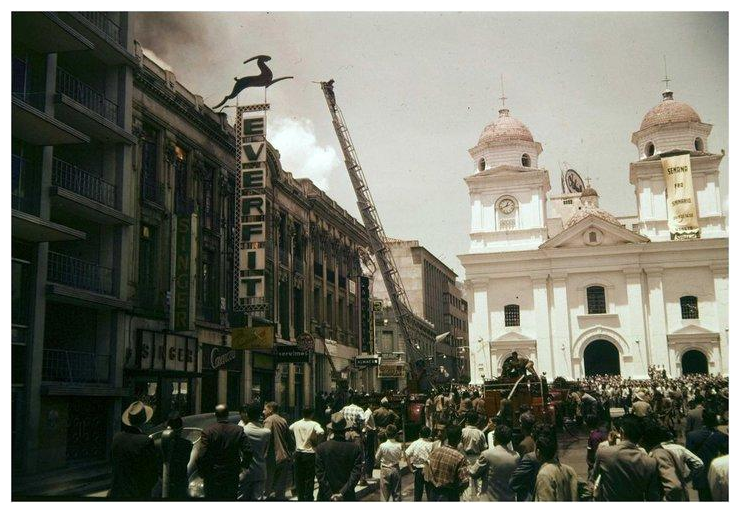

Fuente: Carvajal, 1959

(...) para cruzar el caos en movimiento, debe ajustarse y adaptarse a sus movimientos, debe aprender no sólo a ir al mismo paso, sino ir al menos un paso adelante. Debe hacerse un experto en sobresaltos y movimientos bruscos, en giros y contorsiones súbitos, bruscos, desconyuntados, no sólo de las piernas y el cuerpo, sino también de la mente y la sensibilidad (Berman, 1991:160).

En la calle la escenografía urbana se presta para el encuentro entre quienes aplauden el avance vigoroso del proyecto moderno y quienes se ven absortos y confundidos por la acelerada transformación del paisaje. Lo curioso, como lo manifiesta Berman (1991), es que ambos obstruyen la libre circulación de los vehículos, artefactos para los cuales se diseña la ciudad, la misma que se ocupa de intentar evitar que los enfrentamientos entre los distintos actores tengan lugar. De ahí el surgimiento de la autopista, que en las décadas siguientes se constituye en el principal componente ordenador del territorio. 
Foto 28. Demoliciones en la calle unión para dar paso a la avenida oriental

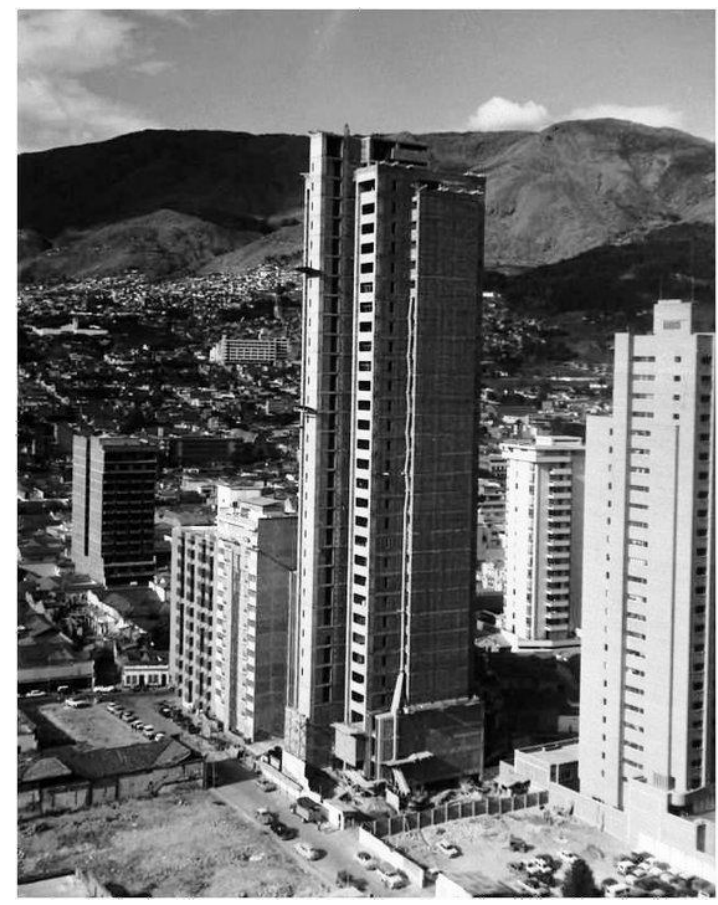

Fuente: Carvajal, 1973
Ilustración 16. Plano del proyecto de la avenida (oriental) que irrumpe sobre el núcleo central de Medellín

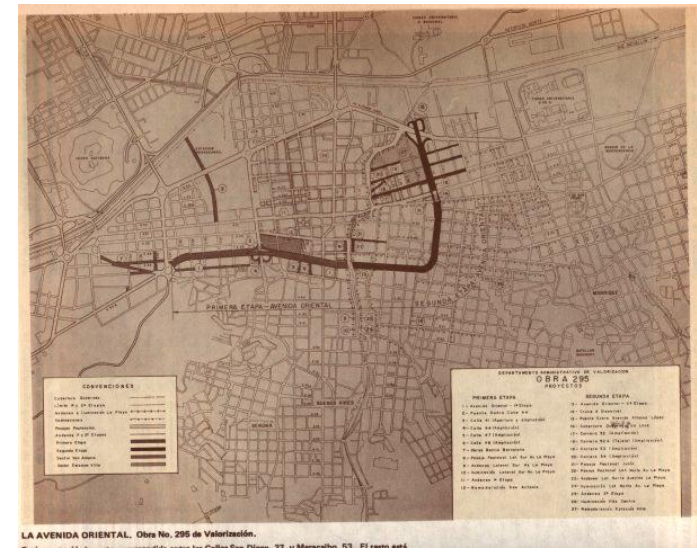

Fuente: Departamento Administrativo de Planeación Municipal. Plan vial

Foto 29. Niños pintando las culatas (muros ciegos) que dejo la apertura de la avenida oriental

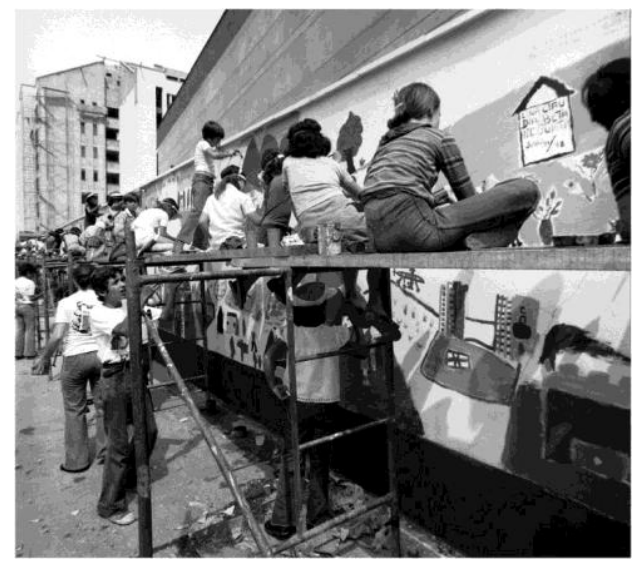

Fuente: León Ruíz, 1978

La antigua calle moderna, con su voluble mezcla de personas y tráfico, negocios y vivienda, ricos y pobres, ha sido ordenada y dividida en comportamientos separados, con entradas y salidas estrictamente vigiladas y controladas y carga y descarga fuera de la vista, donde las zonas de aparcamiento y los garajes subterráneos son la única mediación (Berman, 1991:169). 
Ilustración 17. Localización de los elementos iconográficos del paisaje urbano de 1925-1940 y sus principales rasgos
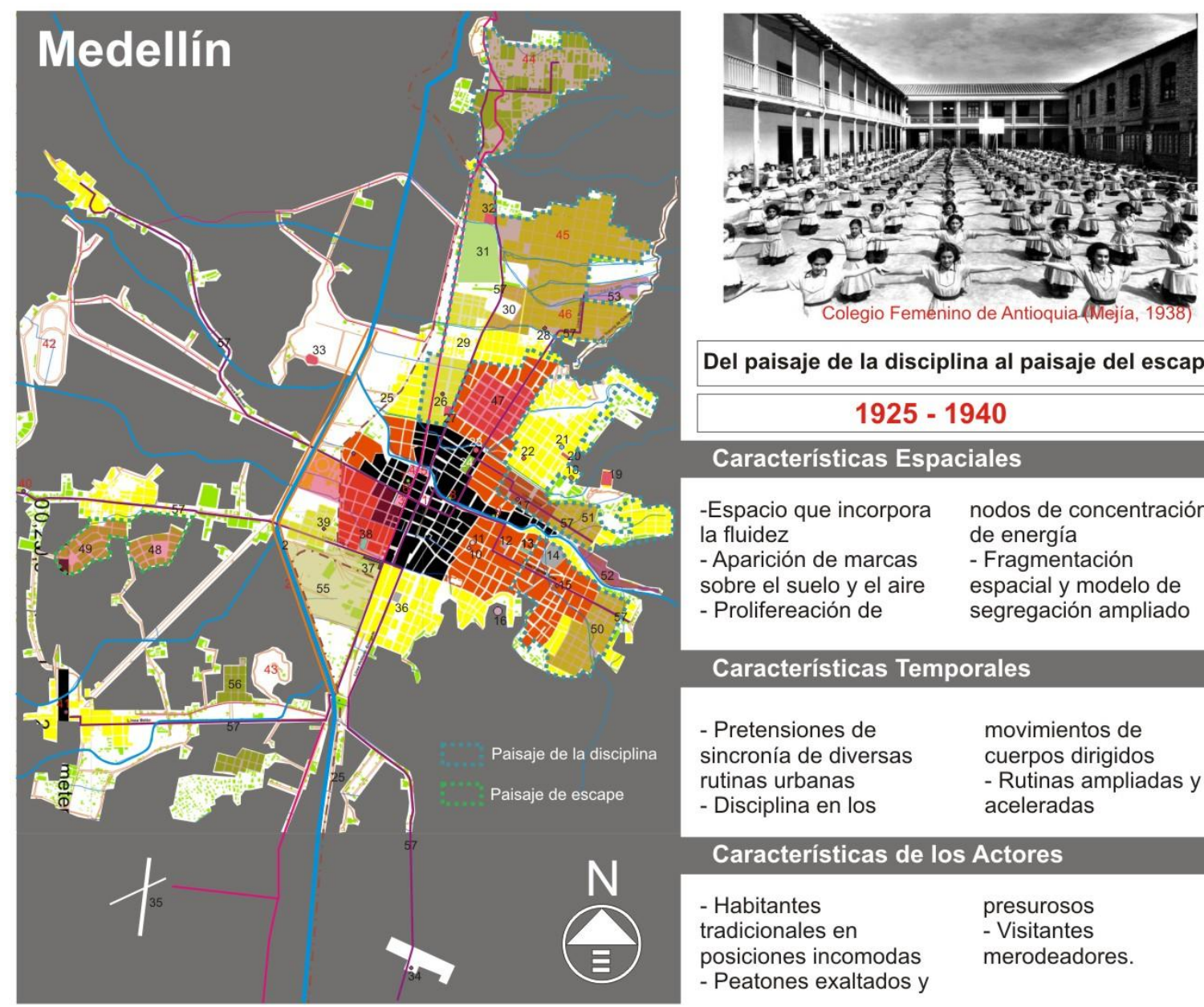

Del paisaje de la disciplina al paisaje del escape

1925 - 1940

Características Espaciales

-Espacio que incorpora la fluidez

- Aparición de marcas

sobre el suelo y el aire

- Prolifereación de nodos de concentración de energía

- Fragmentación espacial y modelo de segregación ampliado

\section{Características Temporales}

- Pretensiones de sincronía de diversas rutinas urbanas

- Disciplina en los movimientos de cuerpos dirigidos - Rutinas ampliadas y aceleradas

\section{Características de los Actores}

- Habitantes

tradicionales en

posiciones incomodas

- Peatones exaltados y presurosos

- Visitantes

merodeadores.

Elementos configuradores del espacio urbano

1. Parque Berrio (Plaza Mayor)

2.Paseos Los Libertadores y Conq

3. Palacio Nacional

4. Palacio Municipal

5. Palacio Departamental

6. Iglesia La Veracruz

7. Museo

8. Hotel y teatro Europa

9. Palacio de Bellas Artes

10. Colegio San Ignacio

11. Universidad de Antioquia

12. Colegio Femenino de Ant.

13. Plaza de Mercado Florez

14. Fábrica Coltejer

15. Iglesia Sagrado Corazón

16. Monumento El Salvador

17. Iglesia EI Sufragio

18. Cárcel La Ladera

19. Escuela Normal Superior

20. Colegio Los Angeles

21. Hospital Los Angeles.

22. Escuela Nacional de Minas

(Post. Colegio Maria Auxiliadora)

23. Catedra

24. Parque Bolivar
25. Ferrocarriles

26. Iglesia Jesús Nazareno

27. Escuela Modelo

28. Iglesia Jesús de La Misericordia

29. Hospital San Vicente

30. Cementerio San Pedro

31. Bosque de La Independencia

32. Escuela de Varones Miranda

33. Facultad de Agronomía

34. Iglesia San José (Poblado)

35. Aeródromo Las Playas

36. Compañía de Tabaco

37. Estación Medellín

38. Plaza de Mercado Guayaquil

39. Iglesia Sagrado Corazón

40. Iglesia en La América

41. Iglesia Nuestra Sra de Belén.

42. Hipódromo

43. Cerro de Los Cadavides

$44,45,46,50,51,56$. Barrio Obreros.

48, 49. Barrios Garden City.

52, 53. Arrabales

55. Talleres de los ferrocarriles

57. Tranvía

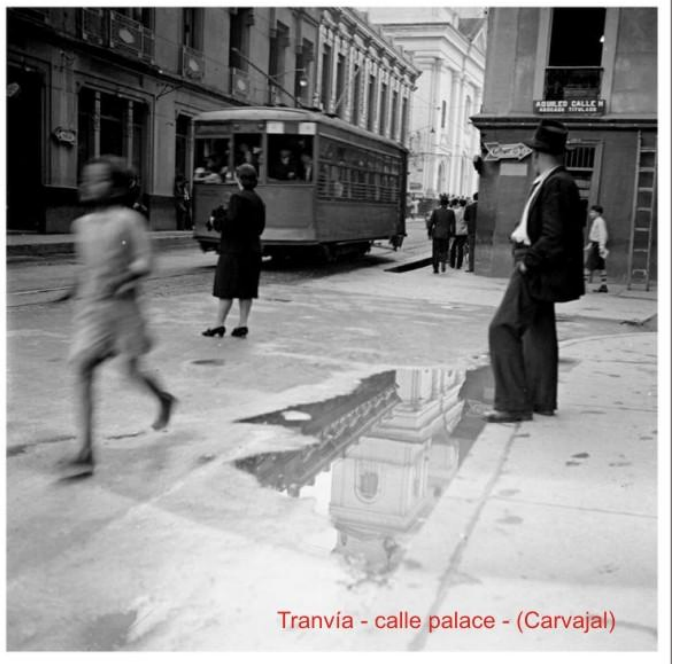

Fuente: ilustración elaborada por el autor con base en la cartografía y fotografía de la época. 
Ilustración 18. Localización de los elementos iconográficos del paisaje urbano de 1940-1950 y sus principales rasgos

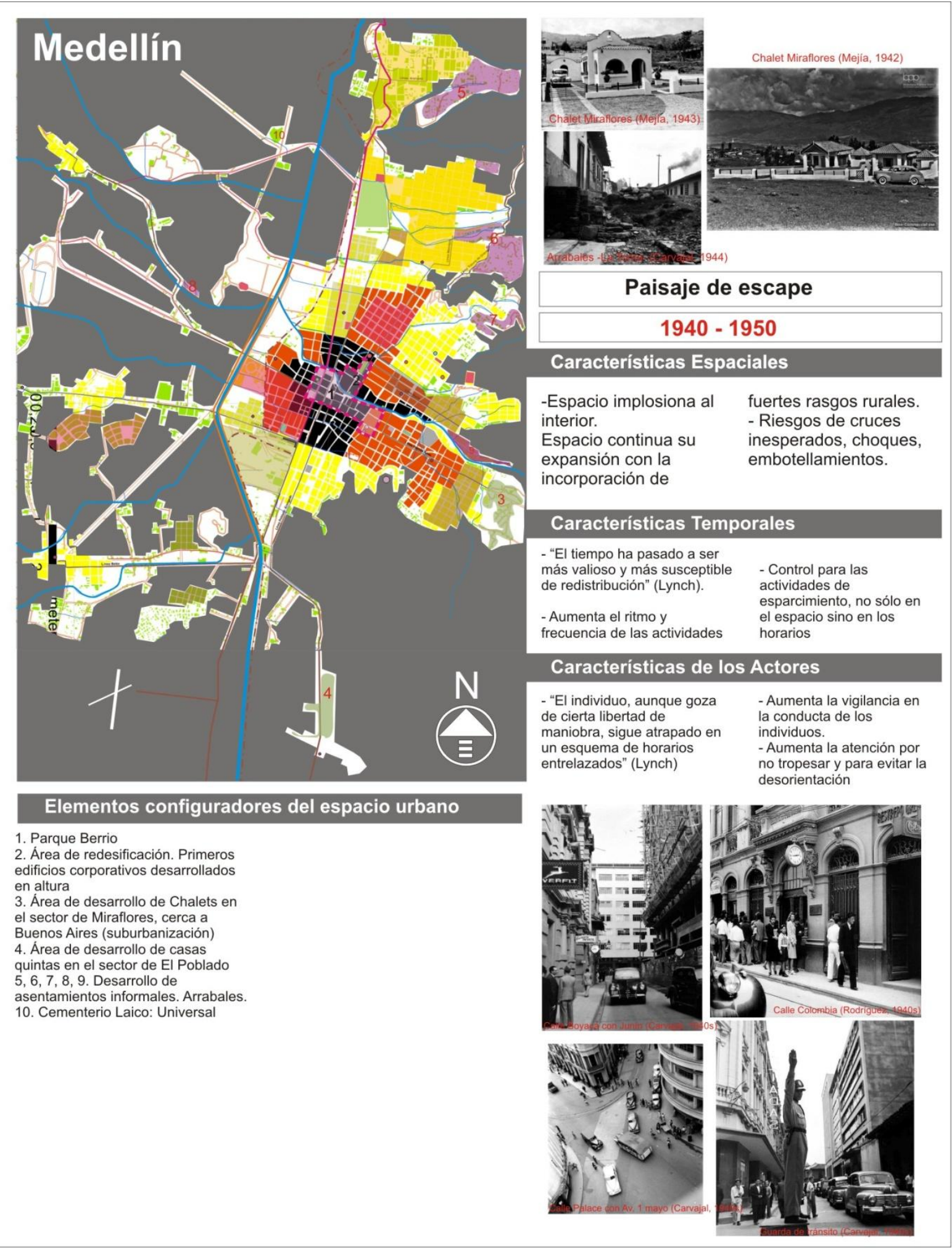

Fuente: ilustración elaborada por el autor con base en la cartografía y fotografía de la época. 
Ilustración 19. Localización de los elementos iconográficos del paisaje urbano de 1950-1970 y sus principales rasgos

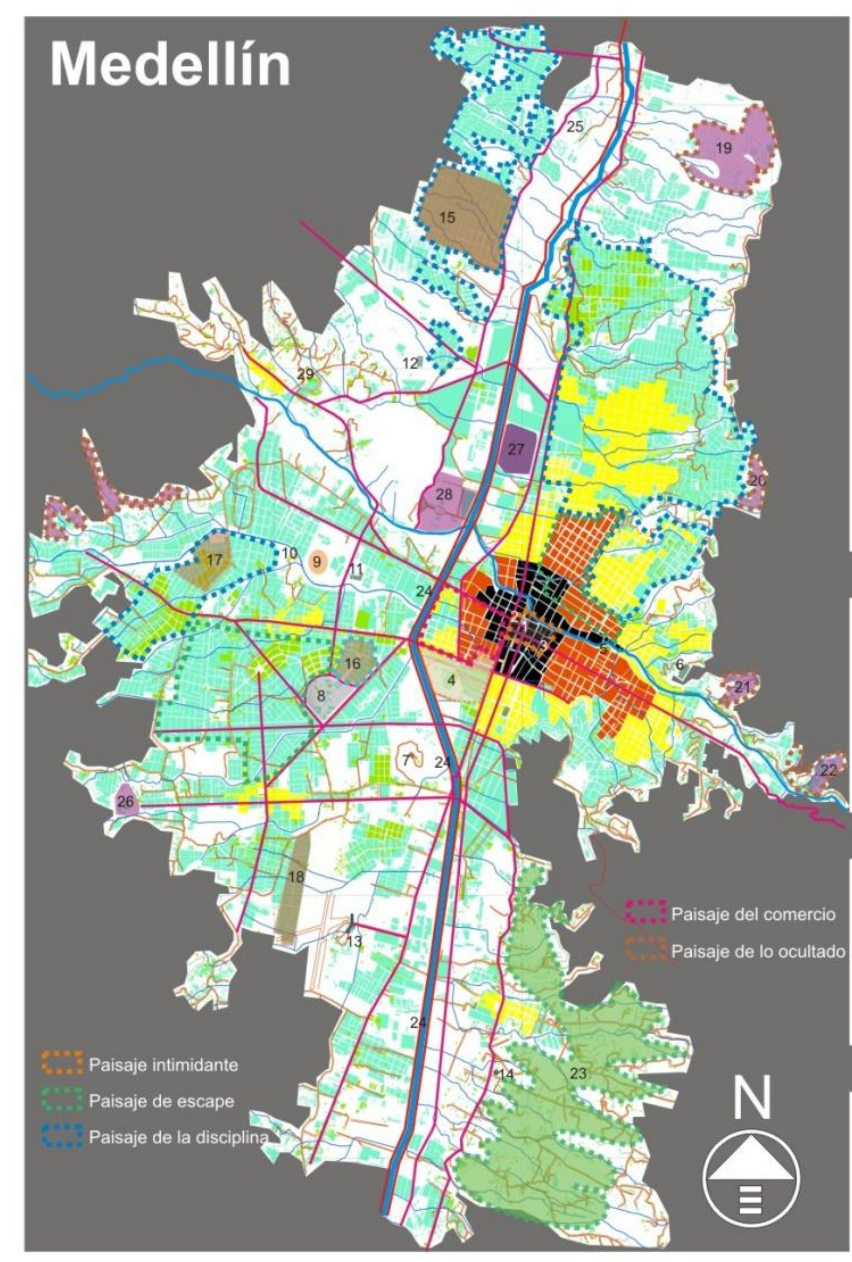

Elementos configuradores del espacio urbano

1. Parque Berrio

2. Incendio a los alrededores del parque Berrio

3. Avance del proceso de

redensificación de la zona centro

4. Área subutilizada por el cierre de

los ferrocarriles.

5. Teatro Pablo Tobón Uribe

6. Colegio San José

7. Recreación de un "pueblito paisa"

en el cerro Nutibara (antes

denominado de los Cadavides)

8. Universidad Pontificia Bolivariana

9. Estadio

10. Velodromo

11. Colegio San Ignacio (trasladado)

12. Hospital Pablo Tobón Uribe

13. Aeropuerto

14. Club campestre

$15,16,17,18$. Nuevos barrios

obreros

$19,20,21,22$. Barrios informales

23. Zona de casas quintas.

24. Prolongación de los paseos de

Los Libertadores y Los
Conquistadores, ahora autopistas norte y sur.

25. Feria de ganado

26. Universidad de Medellín

27. Universidad de Antioquia

28. Universidad Nacional

29. Facultad de Minas (Trasladada)

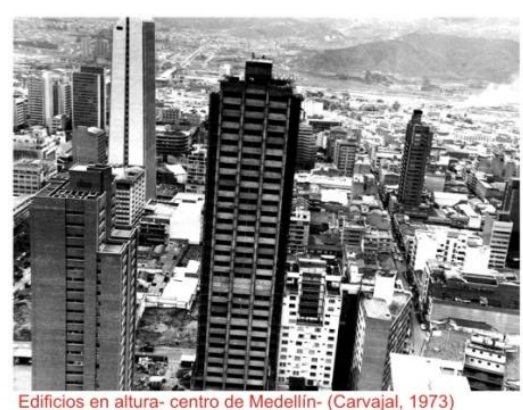

\section{Paisaje apabullante e intimidante}

\section{$1950-1970$}

\section{Características Espaciales}

- El espacio se

expande e implosiona

- Se configura un

espacio urbano para

individuos en movimiento y ya no para multitudes en movimiento. (Sennett)

- El espacio es ahora más neutral

\section{Características Temporales}

- Movimiento incesante de los paralelo cuerpos.

- Aceleración en la cadena los continuo y constante.

hábitos urbanos

- Intensidad de

continuo y constante.

- Espacios de habitación
con formas de mayor

acontecimientos vividos en regularidad y disciplina

\section{Caracteristicas de los Actores}

\section{- La gente se mantiene en un constante movimiento \\ perdiendo así el vínculo con \\ los otros y con los lugares \\ - Cuerpos insensibles a}

pesar de mostrarse con

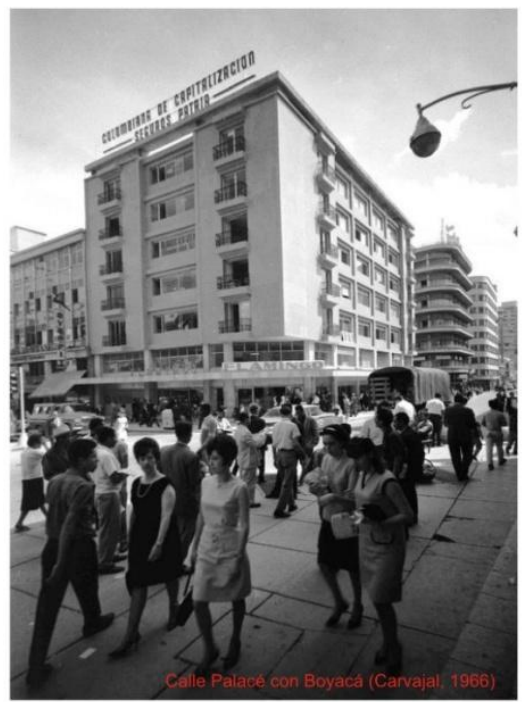

Fuente: ilustración elaborada por el autor con base en la cartografía y fotografía de la época. 


\subsubsection{Estratos narrativos producidos entre 1970 y 2010}

Medellín en el último periodo de 40 años incrementó su área urbana en un 119\% aproximadamente, obteniendo bajo este dominio 12.398 hectáreas, según registros para el 2010. Su índice de expansión urbana se reduce ostensiblemente a partir de la década de los 90 del siglo XX, debido a que esta energía de crecimiento prácticamente ya acaparó el suelo disponible en un valle estrecho, como en el que se asienta esta ciudad. En lo que respecta a su índice de crecimiento poblacional, que es de $151 \%$, señala que la ciudad pasa de tener 1'077.252 habitantes en 1973, a albergar 2'706.087 ciudadanos según recientes estadísticas del año 2011.

El paisaje urbano de Medellín se convierte en una complejísima textura, en cuya construcción participan decididamente las lógicas de lo informal, ante el incremento de pobladores provenientes en su mayoría del mundo rural, sin otra oportunidad distinta que engrosar las áreas de la marginación que desde mediados del siglo XX vienen configurando parte de la ciudad. Participa también, el capital financiero privado, que con el aval del estado, incrementa la oferta de vivienda, el cual aumenta su rentabilidad en las operaciones, reduciendo ostensiblemente las condiciones para construir un espacio urbano de calidad, consolidándose así un modelo de segregación, apreciable en las áreas diferenciadas para la promoción de productos inmobiliarios discriminados por las clases socioeconómicas.

Finalmente, el estado, especialmente la administración municipal en intentos de reacción, se propone reducir las brechas sociales, políticas y culturales que caracterizan el paisaje urbano de Medellín, a través de intervenciones de carácter monumental, esperando cautivar los ojos de los ciudadanos, con nuevas ilusiones y simulacros urbanos, a través de las escenografías denominadas del "urbanismo social".

\section{- Paisaje de lo ocultado o de lo invisibilizado}

A la ciudad llegan miles de gentes provenientes de un ámbito muy ajeno a las lógicas del mundo urbano, que no son incluidas formalmente al desarrollo político, económico, social y cultural que esta misma promueve. Ante la necesidad de un techo, dichas familias campesinas inician la construcción de su propio entorno sobre áreas que no son valoradas, por efectos de la norma urbana o porque no son del interés del mercado formal de tierras.

Frente al desconocimiento de la técnica urbana desarrollada para la configuración espacial de la ciudad, los excluidos recrean las lógicas de los lugares de donde provienen, para adaptarlas a los sitios colonizados, la mayoría de ellos situados en áreas topográficas de alta pendiente, características de las vertientes de un valle estrecho como en el que se asienta Medellín. El resultado es la configuración de un espacio orgánico, con formas inusitadas, producto del reciclaje de materiales que desecha la ciudad formal, y en donde el enmarañamiento de las calles estrecha las relaciones entre el espacio público y el espacio privado, a tal punto que no se puede reconocer el uno o el otro. 
El espacio habitado, aunque estrecho y escaso, pareciera no tener límites, ya que la lógica del ensanchamiento es el de la espontaneidad, adosando áreas al espacio construido en todas direcciones, hasta donde sea posible la imaginación. La noción del tiempo es de una perpetua transitoriedad, pues las mismas condiciones de precariedad impulsan un constante deseo de mejoramiento, ya que del cartón, el barro y las latas se aspira llegar al ladrillo, el vidrio y el concreto.

El edificio comunitario, producto de la autoconstrucción y de la solidaridad entre los moradores del barrio, se instala en el paisaje como una conquista política y social, ya que con éste insisten en el reconocimiento que les debe la sociedad. Dicho artefacto alberga múltiples funciones, desde la educación de los niños, la asistencia social para la salud y la recreación, así como el aforo de las organizaciones que luchan por las reivindicaciones políticas del asentamiento humano, el cual por supuesto tiene por nombre la idea o impulso que los agrupa.

Este tipo de paisaje trata de ser disimulado por la ciudad formal, ya que la imaginación urbana recrea sobre esta los estereotipos de lo que se teme y no se desea. ${ }^{40}$ Situación que es difícil continuar sosteniendo ya que los paisajes de la ciudad informal, en casos como Medellín, no están ocultos, sino muy visibles ya que en la actualidad configuran gran parte de la imagen diaria que observan sus habitantes.

\section{- Paisaje reducido y de la pérdida de valores urbanos}

Con el crecimiento disparado de las ciudades y el incremento de las densidades, especialmente entre las décadas del cincuenta y setenta del siglo XX, la política nacional de vivienda que había surgido desde los años treinta toma un auge considerable, dado que la oferta no alcanza a suplir las amplias demandas de la población. Instituciones estatales toman el liderazgo en la construcción de vivienda obrera, durante un clima político tenso, y durante la transición de una dictadura y la retoma del poder de las clases dirigentes tradicionales, en un Frente Nacional en el que se acuerdan los turnos de gobierno entre los dos partidos políticos más dominantes.

De vuelta a la democracia, el estado cede el liderazgo en la construcción de vivienda al sector financiero, a través de nuevos modelos de financiación, ya de carácter privado. Con esto se instaura el urbanismo del Frente Nacional, en donde la política de lo urbano se reduce a la construcción de vivienda en serie, dejando en el olvido la generación de escenarios suficientes en calidad y cantidad, para el desarrollo de la vida urbana.

Se asiste a una denotada precariedad estética en la incursión de los nuevos componentes en que se soportan las escenas cotidianas, de una no despreciable cantidad de habitantes en una ciudad ya de carácter metropolitana. Los programas para atender la recreación y esparcimiento de la población, por ejemplo, se condensan en la multiplicación de placas polideportivas, en donde la mujer no encuentra lugar de expresión, y los niños, frente a la escasez, compiten con los adultos por los escenarios de recreación.

\footnotetext{
40 "La renovación y recuperación de las zonas deprimidas tuvo que ver principalmente con la reglamentación de los barrios denominados como piratas. Según las autoridades municipales, en ellos Medellín afrontaba un gran obstáculo para su desarrollo armonioso, pues en 1964, éstos ya pasaban de los sesenta y eran ocupados por unos 120.500 habitantes, aproximadamente el 18\% de la población urbana de la Ciudad" (García, 2000:211).
} 
Foto 30. Niños jugando al microfútbol en placa polideportiva

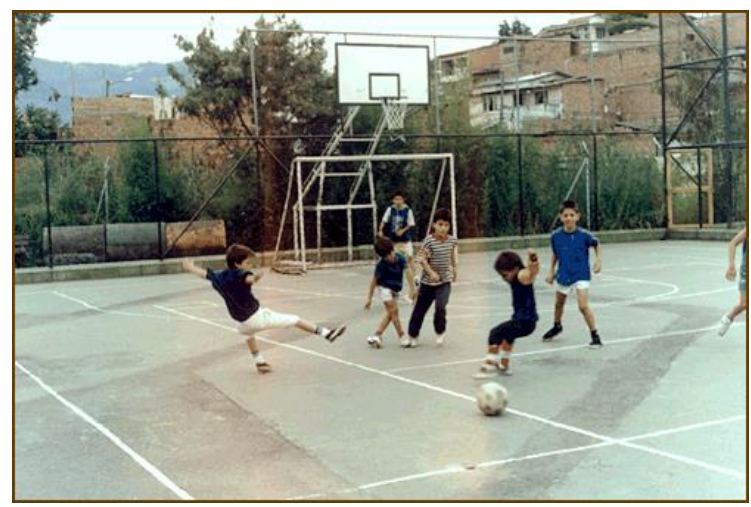

Fuente: archivo Vistaz.

(...) movimientos espirituales y culturales, a pesar de su poder eruptivo, han sido borboteos en la superficie de un caldero social y económico que ha estado hirviendo y derramándose durantes más de cien años (Berman, 1991:122).

Las pretensiones de la burguesía de finales del siglo XIX y principios del XX, de disponer de lugares diversos para la promoción de la cultura y el disfrute del ocio, quedó tan sólo en unas contadas materializaciones en el centro de la ciudad, que no alcanzan a cubrir la multiplicada demanda de los cientos de miles de habitantes. En las amplias periferias colonizadas, la política social y cultural disemina artefactos de insuficiente impacto, en el propósito de un proyecto de ciudad incluyente. Ante esto, como lo anota Berman (1991), hombres, mujeres y niños han abandonado sus posiciones morales, políticas y económicas. “(...) a menudo el precio de hacer avanzar y expandir la modernidad es la destrucción no sólo de instituciones y ambientes tradicionales y premodernas, sino también -y aquí reside la verdadera tragedia- de todo lo más vital y hermosos del propio mundo moderno" (Berman, 1991:310).

\section{- Paisaje del ensimismamiento o la reclusión}

El proyecto de ciudad impulsado por la élite a finales del siglo XIX y las primeras décadas del XX entraba en crisis, ya que el panorama físico evidenciaba amplias brechas entre los diferentes sectores sociales. Sin embargo, la preocupación de las clases dirigentes se centraba más en resolver la apariencia $^{41}$ de una ciudad convulsionada que en afrontar las causas de fondo que insinuaban el fracaso de una ciudad delineada ya casi un siglo atrás.

\footnotetext{
41 "La imagen de Medellín se había deteriorado a tal punto que los que antes la admiraban por su progreso ahora la miraban con malos ojos; su imagen ya no era de ciudad industrializada y sitio ideal para hacer inversión sino de paraíso de la droga. Por este motivo fue retirada de los mapas turísticos y sus habitantes empezaron a ser sospechosos de narcotráfico en los aeropuertos internacionales" (García, 2000:254).
} 
Ilustración 20. Localización de algunos elementos iconográficos del paisaje urbano de 1970-2010 y sus principales rasgos

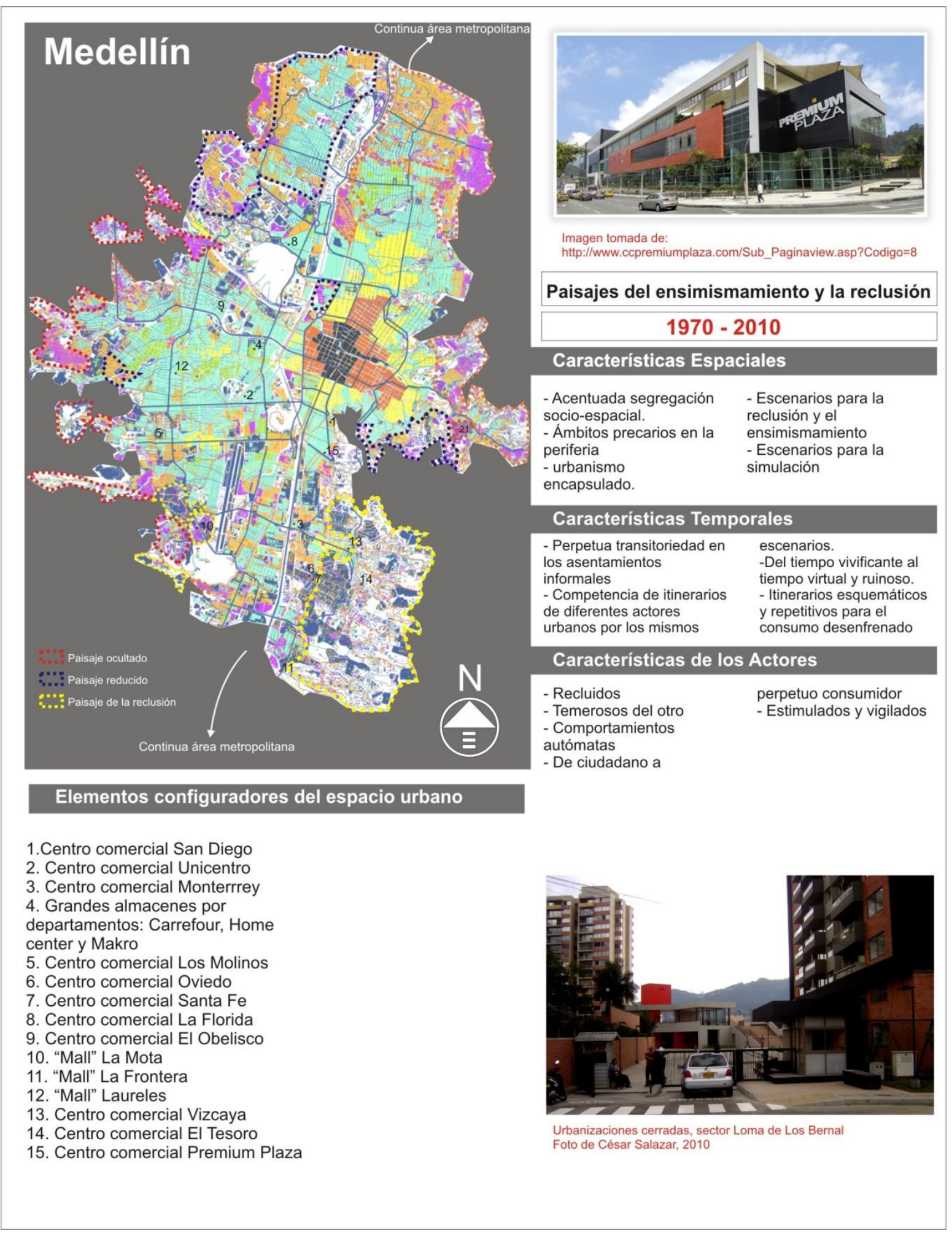

Fuente: ilustración elaborada por el autor con base en la cartografía y fotografía de la época. 
Bajo ese enfoque la ciudad toma un giro al proponer artefactos culturales para la reclusión de sus ciudadanos, asunto que curiosamente, la ciudad burguesa había luchado en disolver como atributo de la herencia colonial. El centro comercial aparece como un montaje urbano, en donde el ciudadano es atrapado en una escenografía de interior que lo trata como un consumidor desenfrenado. La gente adopta formas fluidas y abiertas, ya que están en un perpetuo movimiento, como zombis, en el que sus modos y actuaciones se ven restringidas, hasta distorsionadas (Berman, 1991).

De la calle, del café y del parque, las muchedumbres son trasladadas a un espacio público simulado. Los actores urbanos son constantemente estimulados en su percepción visual, a la manera de un calmante social frente a la conmoción externa, pero como dice Sennett (2002), ya no hay lugar para ni siquiera discutir sobre esa estimulación que sufre la vista. Este reclutamiento de las personas se ve reforzado por la sensación de confort al verse vigiladas, sin apreciar que están perdiendo la oportunidad de narrarse a sí mismas, de construir el espacio, de hacer el ejercicio de rememoración.

El barrio también como producto de la ciudad moderna tiende a disolverse, a partir de la propuesta del paisaje del ensimismamiento. Desde que el estado entregó al sector financiero la construcción de vivienda, éste ha promovido la consolidación de un producto inmobiliario, el conjunto residencial cerrado, que comienza a extinguir la vecindad. $\mathrm{Y}$ tanto en los centros comerciales como en la proliferación de conjuntos residenciales cerrados, los ciudadanos recurren a un "repertorio de imágenes" (Barthes), para afrontar las sensaciones perturbadoras que pueda ocasionar el encuentro con los otros.

El repertorio de imágenes del ensimismamiento proporciona categorías sencillas y generales, estereotipos sociales en dónde encuadrar al otro y así asumir posiciones pasivas e indiferentes frente a la diferencia. 'Las masas no tienen 'yo', ni 'ello', sus almas están vacías de tensión interior o dinamismo: sus ideas, necesidades y hasta sus sueños 'no son suyos'; su vida interior está 'totalmente administrada', programada para producir exactamente aquellos deseos que el sistema social puede satisfacer, y nada más" (Berman, 1991:16).

\subsection{Lectura del paisaje en su mosaico actual, desde el eje vertical o desde la colonización de los elementos-iconos sobre el espacio urbano}

En la lectura anteriormente realizada se expuso cómo en el espacio urbano de Medellín se agregaron unos estratos narrativos (capas), correspondientes a unos tipos de paisaje en los que predominan atmósferas específicas, en las cuales el espacio, el tiempo y los actores toman características singulares. Aún así, para descifrar las lógicas de construcción y transformación del paisaje urbano, es necesario descronologizar el contenido narrativo, dando mayor énfasis al tiempo semiológico que otorgan los elementos que colonizan el espacio en diferentes momentos de la historia.

Una lectura del eje vertical de la matriz de la expansión urbana (a la manera de conformar un instrumento de arqueología del paisaje urbano) permite sobre la superficie discursiva, como se considera en esta caso a la ciudad, identificar la sintaxis funcional, o si se quiere las diferentes reglas de combinación en las que el paisaje muestra cambios y transformaciones. El paisaje urbano asume unas características especiales dependiendo del elemento colonizador principal, ya que la cultura 
reconoce en estos unas formas de apropiación del espacio, unos modos de experimentar el tiempo, y unas "conductas adecuadas" de los individuos.

Para lograr hacer este tipo de lectura transversal se requiere superar los planteamientos lineales y acercarse más a esquemas de orden rizomático, a ese orden que adquieren los mecanismos de los seres vivos para garantizar su supervivencia. Y esta es una de las propiedades del paisaje, que no es sólo producto de una imagen congelada, sino que es un sistema de información que necesita diversas formas para transportar la información por el medio urbano.

Identificamos unos tipos de paisajes producto del proceso de crecimiento de la ciudad de Medellín, en los que se evidencia cómo el borde urbano actúa como un vector comunicante de la experiencia ganada en el ámbito urbano, pero también como transgresor de la misma al incorporar nuevas pautas reconocidas a través de los iconos que impone en la escena urbana. Esta situación genera dinámicas excitantes sobre el espacio urbano, ocasionando que estas múltiples formas de concebir y experimentar el paisaje no permanezcan inmóviles, sino que avancen sobre el territorio, construido y no construido aún, adoptando según los casos distintas estrategias de colonización, y produciendo a su vez paisajes de lo emergente o de emergencia, palpables en la actualidad.

El paisaje urbano es una suerte de narraciones imbrincadas, en las que incluso pueden superponerse estructuras sintácticas que se dirigen en direcciones opuestas, o escenas urbanas en el que se aprecian unidades paisajísticas que se construyen lentamente, adyacentes o superpuestas con otras de construcción más acelerada, que no deben confundirse con los procesos de maduración o evolución de las mismas.

Para dirigir la investigación en tal sentido, se apela al instrumento del mosaico regularizado de imágenes, que como se expuso en el numeral 2.3.1 se apoya en un registro guiado a través de los recorridos que señalan cada uno de los bordes de expansión de la ciudad, en las etapas previamente identificadas, sobrepuestas a la malla urbana que configura la experiencia vivida en la actualidad.

También, haciendo uso de las bases de datos que ofrece la cartografía del Plan de Ordenamiento Territorial de Medellín, se generan unos mapas de densidad relacionados con los iconos urbanoarquitectónicos reconocidos como colonizadores del espacio urbano en la historia urbana de la ciudad. Este registro del estado actual, con respecto a la evolución de la colonización realizada por los elementos significativos del paisaje, contrastado con la lectura del hilo horizontal del crecimiento de la ciudad, permite reconocer las transformaciones más relevantes del paisaje, así como encontrar las reglas de combinación, e identificar los conflictos entre la significación y la realidad misma, es decir, entre la significación y la función, entre la significación y la razón (la planeación urbana).

\subsubsection{Identificación de los tipos de borde, característicos en el paisaje urbano de Medellín}

Asumido el paisaje como resultado de la superposición o imbricación de estratos narrativos, construidos a través del tiempo, y que en anteriores apartados se sintetizaron para distinguir la conformación de las estratos narrativos configurados a partir de un proceso histórico que nos indica 
los cambios sucedidos en130 años, nos permitimos ahora indagar por el comportamiento de los bordes, productos de la fricción y colisión entre estos estratos narrativos del paisaje.

Estos bordes urbanos, dependiendo de las fuerzas y las direcciones que siguen en diversos casos, configuran distintos tipos de estructura; retomando a Deleuze y Guattari (1994), unas muestran un comportamiento más estable, llamadas plegamiento, y otras, mayor inestabilidad o más dinamismo en el cambio y adopción de formas, a las que denominaremos sedimentación. Para el primer caso es necesario diferenciar las distintas formas que puede adoptar, en esta investigación se consideran las siguientes: aglutinantes, conglomerado, integrado y jerarquizado; y para el segundo tipo de borde, las formas predominantes que se desprenden son: desperdigado, desagregado, amontonado y saturado.

El conocimiento previo de las características dominantes de cada estrato narrativo, con las escenografías urbanas que configuraban, según la disposición y distribución de los componentes en el tiempo y en el espacio, permite, con la confrontación del panorama del mosaico de imágenes contemporáneas, identificar la estrategia de colonización dominante: la codificación o la descodificación. Como se aclaró en el capítulo de fundamentos teóricos (capítulo 2), ambas estrategias son inherentes, sin embargo, dependiendo de las circunstancias, se aprecia un predominio especial de la una sobre la otra.

La confrontación de la dinámica del borde urbano en el panorama actual, con relación a los estratos narrativos precedentes, admite también reconocer el proceso activo de colonización del territorio: la reterritorialización que emprenden algunos componentes semióticos, o la desterritorialización en que otros se ven abocados, emprendiendo el exilio a otros sectores del territorio. Y finalmente, si estos procesos de expansión, crecimiento, colonización y mutación muestran dinámicas de propagación rápida, lenta o si incluso se aprecian anuladas o prisioneras.

\section{- Recorrido por el paisaje urbano contemporáneo de Medellín a través de los estratos narrativos de 1870-1890, 1890-1910 y 1910-1925}

El ejercicio consiste en identificar los itinerarios que configuran en la actualidad el recorrido de los bordes urbanos que se consolidaron en los cortes temporales de 1890, 1910 y 1925 (ver Anexo con el registro fotográfico de los recorridos efectuados por los bordes de los estratos narrativos). A partir de este registro, se hace un trabajo de restituir en imágenes las franjas que remarcan y expresan las formas del paisaje urbano, producto de la colisión y las rupturas, que emergen entre los estratos narrativos.

Se acude al registro fotográfico, para encontrar las evidencias de los estratos narrativos posteriores a los cortes señalados, superpuestos a estos. También se capturan pruebas que muestran las posibles fracturas producidas por las colisiones de los bordes, originando resquebrajamientos y hendiduras al interior mismo de las placas urbanas, como en el núcleo génesis de la historia narrativa del paisaje urbano de Medellín. Tal situación se corrobora y ajusta con un análisis morfológico a partir de la cartografía más actualizada, sobre la cual es posible identificar las áreas fronterizas que se producen por la colisión de los diferentes estratos narrativos. 
En el proceso de crecimiento de la ciudad, los bordes siguen diferentes direcciones sobre el espacio urbano, transportando la herencia cultural que trae a cuestas la ciudad, pero aprovechando la oportunidad para introducir nuevos elementos de significación para la recolonización urbana. Es así que la ciudad al expandir sus fronteras sobre el territorio, se transforma no sólo por su aumentado tamaño, sino por estas mismas fuerzas expansivas que modifican los rasgos característicos del interior de la ciudad.

Este comportamiento activo en la ciudad produce sobre el paisaje urbano unas franjas de ruptura, o si se prefiere de colisión, pues las fuerzas expansivas de la ciudad se producen por reacción a unas tendencias de contracción de la misma. Esto surge por la confrontación que se da continuamente entre la ciudad y la arquitectura, en donde la primera asume resistencia a la transformación, mientras que la arquitectura insiste con su fuerza transformante (Ramos, 2004).

Martín Ramos (2004) aclara que en el fenómeno urbano el sujeto actúa como un creador desde la fantasía y la imaginación sobre la ciudad que, "siempre ya presente", se resiste a la pretensión de empezar de cero, a ser simplemente considerada como un edificio arquitectónico. En el borde urbano la arquitectura no sólo produce y desarrolla nuevas formas, ya conocidas gracias a la ciudad, sino que también produce formas emergentes que trastornan el sustrato de imágenes con las que se ha construido la ciudad.

La ciudad en el proceso de crecimiento muestra cómo los estratos narrativos se superponen, evidenciando el registro en terreno de las diferentes trazas, o marcas exteriores que sirven de enlace y apoyo al trabajo de la memoria (Ricoeur, 2008). La arquitectura, en dicho proceso de transformación, añade otras capas de significado con sus propios mecanismos de lectura (Ramos, 2004). Estos desplazamientos y transformaciones del paisaje urbano dejan rastros de permanencia, pero también de intentos de borrado, que son característicos de la ciudad contemporánea, la cual, el ciudadano procura hacerla intelegible en sus trayectos y estancias.

Es por esto que en las franjas de ruptura y colisión, entre los estratos narrativos que constituyen el palimpsesto urbano, se aprecian las diversas estrategias que definen los mecanismos de lectura de los espacios de articulación que genera la estructura urbana y la arquitectura. Es en las zonas fronterizas donde es posible identificar los lapsus del texto urbano, las anomalías que trastornan la rememoración ${ }^{42}$ en la experiencia ordinaria, ya que nuevos esquemas intentan inscribirse, incluso de manera violenta, sobre antiguas combinaciones, que permiten a los actores urbanos hacer actos de memoria que luchan contra el olvido (Ricoeur, 2008).

Al recorrer los bordes urbanos, que se amalgamaron entre los tres primeros períodos de la excitación urbana de Medellín (1890, 1910 y 1925), como sustratos de la lectura que se nos ofrece en el paisaje urbano en el momento actual, se aprecian distintos tipos de bordes. Estos como lugares en construcción enfrentan el pasado, como fuente de sugerencias, con el deseo de transformación palpable en el paisaje, de las que surgen escenarios producto de estrategias como la desterritorialización y la reterritorialización, en las que se pueden emplear acciones como: el borrado, el ocultamiento, la reescritura y los cambios de significado (Barthes, 1993).

\footnotetext{
42 "El esfuerzo de rememoración consiste en convertir una representación esquemática, cuyos elementos se interpenetran, en una representación llena de imágenes, cuyas partes se yuxtaponen” (Ricoeur: 2008).
} 
Ilustración 21. Identificación de los tipos de borde en la colisión de las placas urbanas de 1890,1910 y 1925, y de estas con el estrato narrativo actual

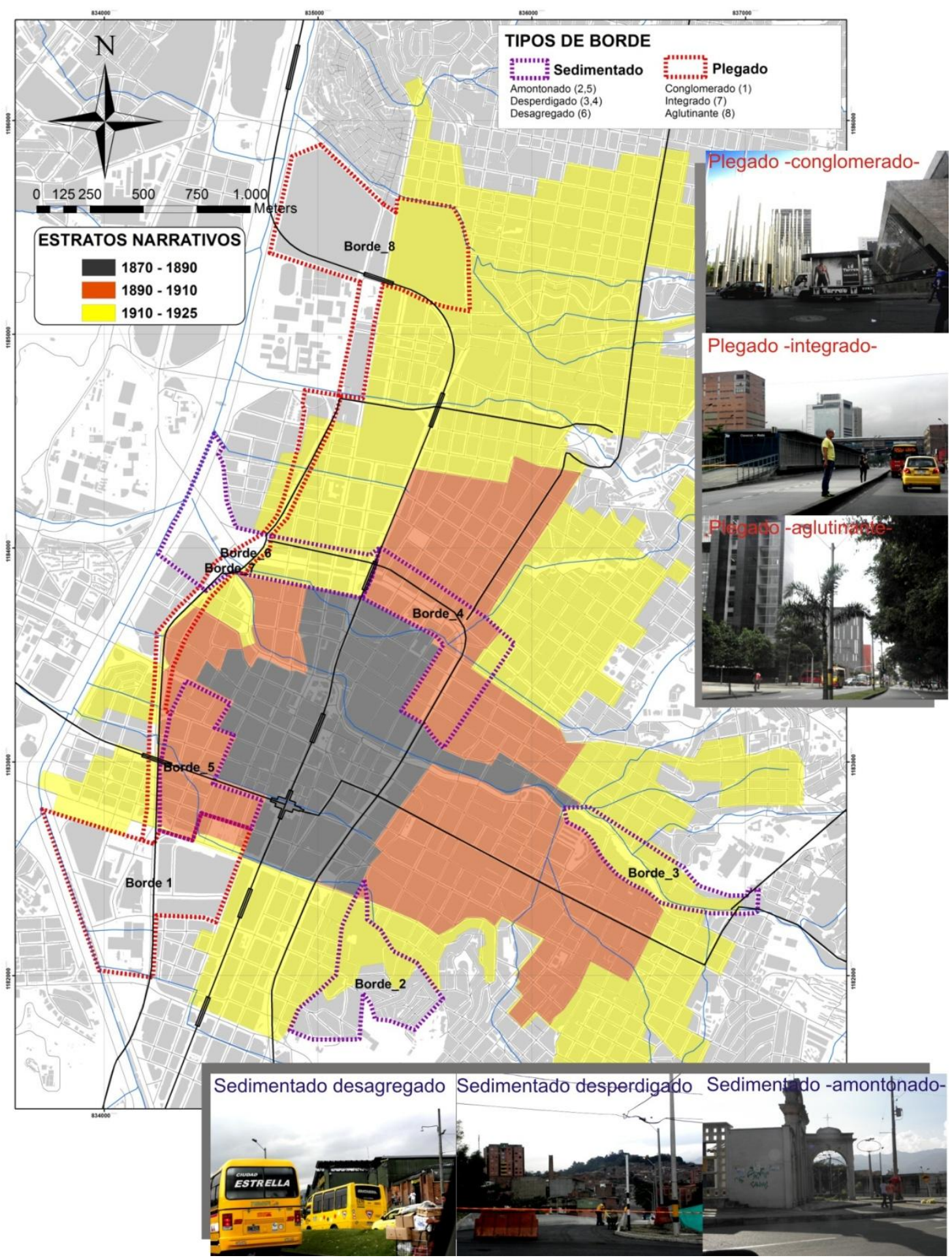

Fuente: ilustración elaborada por el autor con base en la cartografía histórica y el análisis de campo. 


\section{- Recorrido por el paisaje urbano contemporáneo de Medellín a través de los estratos narrativos de 1925-1940, 1940-1950 y 1950-1970}

En 1925 Medellín ocupaba un área urbana aproximada de $8.718 \mathrm{~km}^{2}$, en la década de los cincuenta alcanzó los $11.428 \mathrm{~km}^{2}$. Pero es a partir de 1940 que la ciudad comienza a expandir su dominio urbano sobre las franjas de suelo al occidente del río Aburrá, gracias a que ya se había logrado la canalización de una gran parte del mismo, así como de sus principales tributarios. Por esta razón Medellín, en 1970, desarrolla un área urbana de $56.529 \mathrm{~km}^{2}$, es decir, más de cinco veces la ocupada en 1948 y superior en 6,5 veces respecto al registro de 1925.

El crecimiento del dominio urbano en Medellín, en términos porcentuales, era un reflejo palpable del aumento de su población. En 1928 la ciudad albergaba a 120.044 habitantes, cifra que en 1951 varía a 358.159 pobladores, tamaño poblacional que sigue en denotado ascenso en 1973 con 1.077 .252 ciudadanos. ${ }^{43}$ Como se describió en el primer capítulo ("Planteamiento del problema"), es en el transcurso de estas décadas en las que la ciudad desarrolla grandes áreas diferenciadas, tanto por el modelo de segregación de las clases socioeconómicas como también por las prerrogativas de la planificación moderna, y que en 1948 define un instrumento normativo (Plan Piloto) que separa claramente, en el espacio y en el tiempo, las funciones de residir, trabajar, desplazarse y recrearse.

En 1970 la ciudad registra un crecimiento urbano del 650\% con respecto al área ocupada en 1925, situación que revisada desde una estrategia narrativa del paisaje muestra la proliferación de lapsus en el texto urbano, y la configuración de varios tipos de bordes, rupturas o fracturas en el escenario de la ciudad. En el recorrido realizado entre los bordes que delinean los estratos narrativos de estos tres estadios, y que se agregan a la estratificación del paisaje, fases del proceso de crecimiento de la ciudad, se identifican algunos de estos bordes, que en la actualidad, muestran una dinámica de agitada transformación.

La ciudad incorpora en su proceso de expansión y crecimiento sectores especialmente localizados en el centro-occidente del valle, integrando al dominio urbano antiguos sitios coloniales. En este movimiento se despliegan acciones tanto para albergar barrios para la clase obrera, como para las familias más pudientes, estas últimas escapando especialmente de la movida actividad del núcleo urbano. Al suroriente de la ciudad, como se describe en el primer capítulo, el predominio de la ocupación suburbana soporta el emplazamiento de las casas de campo de la élite local que recrea escenas pintorescas, y empieza a trasladar algunos servicios del gusto burgués, por ejemplo el Club Social (al que luego se llamaría Club Campestre por las características de su localización en esta parte de la ciudad).

\footnotetext{
${ }^{43}$ Las cifras presentadas se citan con base en los censos realizados en el país por la institución autorizada para tales efectos, el Departamento Administrativo Nacional de Estadística-DANE-.
} 
Ilustración 22. Identificación de los tipos de borde en la colisión de las placas urbanas de 1925,1950 y 1970, y de estas con el estrato narrativo actual

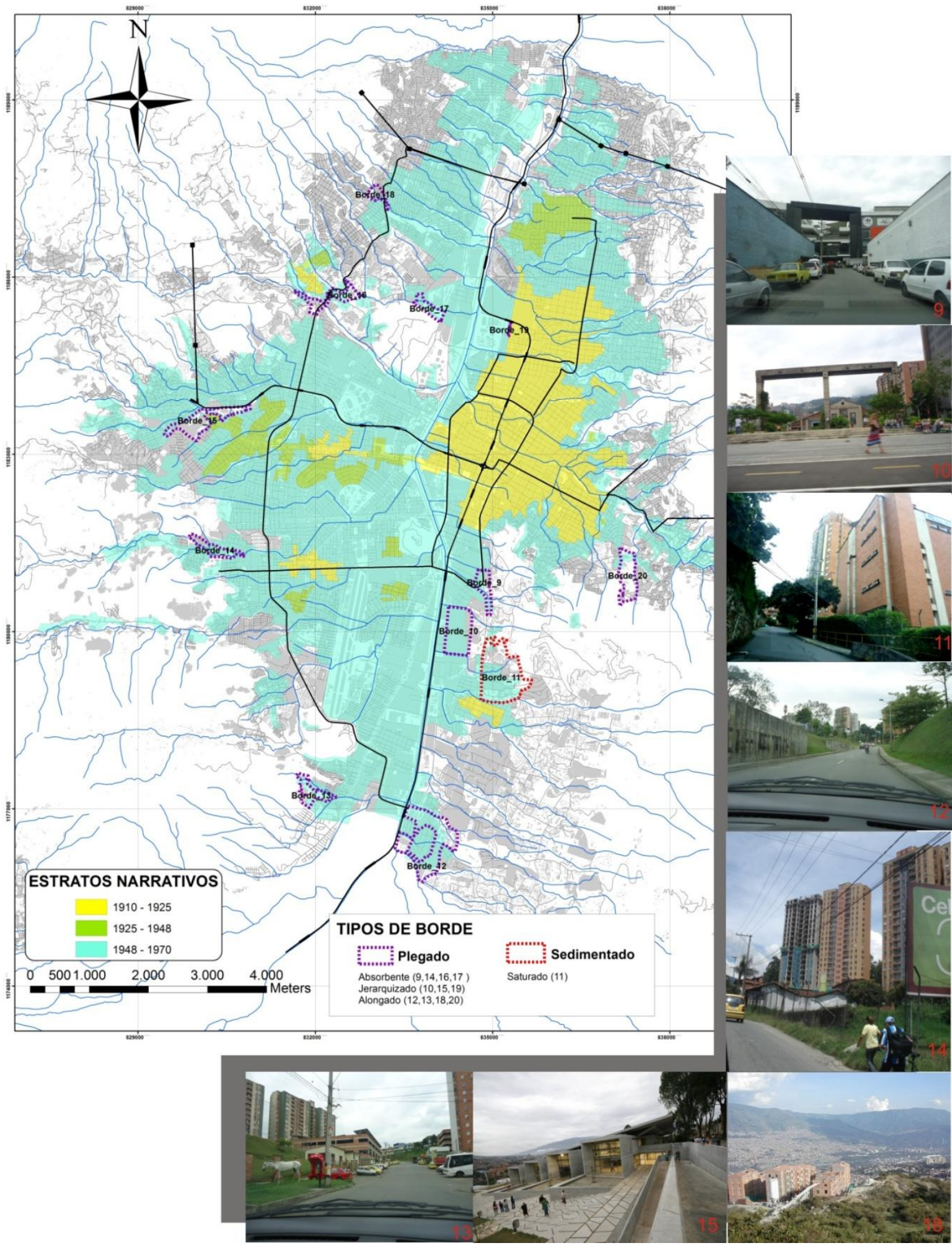

Fuente: ilustración elaborada por el autor con base en la cartografía histórica y el análisis de campo. 
Al norte y al oriente, respecto al núcleo central, la ciudad continúa un proceso de expansión y consolidación de los proyectos inmobiliarios, que algunas familias ricas emprendieron en las primeras décadas del siglo XX, como negocio altamente lucrativo. Lo novedoso es que tal propósito llega a los límites que impone la geografía de laderas de altas pendientes, que aún así, habilita suelos para el asentamiento de amplias masas de campesinos que llegan a engrosar la fila de los marginados de la ciudad.

Al noroccidente de la ciudad se desarrollan, especialmente en este período de crecimiento, los barrios obreros, mediante la gestión estatal para la venta del suelo a los nuevos moradores y la autoconstrucción de las viviendas por los mismos residentes. Las especificaciones de la infraestructura de movilidad, equipamientos colectivos y servicios alcanzan su mínima expresión en este sector de la ciudad, en un período en el cual el urbanismo desarrollado deja en el olvido las prerrogativas del bienestar social, y facilita una aglomeración sobre un espacio sin ningún tipo de molde intencionado que guíe los itinerarios de los actores urbanos.

Los estratos narrativos que soportan este tipo de características urbanas y paisajísticas, confrontadas con el recorrido que ofrece el actual panorama de la ciudad, revelan algunas franjas en las que se aprecian procesos de transformación. Estos dejan al descubierto una producción de imágenes que deben ser re-interpretadas a través de la narrativa del paisaje y su estructura, para así develar las cualidades del espacio, la profundidad del tiempo y el sentido de las rutinas de los actores urbanos.

Lo que evidencia la experiencia en los recorridos entre los estratos narrativos de 1925 a 1970 es que sobre sus bordes se ciñen proyectos que intentan desplegar nuevos escenarios, que modifican sustancialmente las características de los paisajes que configuran la actualidad. Lo que intentaremos es identificar cuáles son las estrategias que se emplean en cada uno de los tipos de borde urbano.

Los tipos de bordes urbanos predominantes entre los estratos narrativos de 1925 a 1970 son entonces aquellos que intentan definir nuevas estructuras que reterritorialicen el paisaje. Las estrategias en síntesis introducen componentes que no sólo incluyen la participación de nuevos actores, sino que inevitablemente aceleran la erradicación de componentes semióticos y agudizan el destierro de actores, en tiempos pasados colonizadores del territorio.

Los bordes de tipo plegado toman así mayor protagonismo en la escena actual, incorporando eso sí nuevas estrategias como la jerarquización, la absorción y la elongación. Como apreciaremos más adelante en cada uno de estos casos se emplean estrategias particulares para suscitar la transformación del paisaje, en las cuales la memoria y el olvido son objeto de manipulación en diferente grado.

En cuanto a bordes urbanos caracterizados por estructuras más inestables, que muestren evidentes imposiciones artefactuales sobre estructuras espaciales o morfologías pretéritas, encontramos sedimentos sobre el paisaje urbano, que revelan algunos residuos originados por este tipo de colisiones. La identificación de este tipo de bordes y la comprensión de las estrategias que emplean para la transformación del paisaje, allana el camino para una propuesta de gestión de la polifonía del paisaje urbano. 


\section{- Recorrido por el paisaje urbano contemporáneo de Medellín a través de los estratos narrativos de 1970-1985, 1985-1996 y 1996-2010}

Para el año 1985 la ciudad amplía su dominio urbano sobre el territorio en un 44\% respecto al área que ocupaba en 1970, expandiéndose especialmente sobre las altas pendientes, tanto en las laderas del oriente como del occidente. Durante este período el sector financiero juega un papel preponderante en la producción de vivienda, promoviendo así un mercado para las clases socioeconómicas media alta y alta al suroriente (El Poblado), y suroccidente (Belén) de la ciudad. Mientras las clases bajas continúan la autoconstrucción de sus entornos urbanos al nororiente y noroccidente de Medellín, con particular predominio.

La ciudad durante esta última fase de expansión consolida la segmentación imaginaria del espacio urbano en diversas escalas y ámbitos. Esto puede constatarse en la división administrativa de sus 6 zonas, 16 comunas y 249 barrios, en los que predominan, dependiendo de su localización, diferentes categorías antropológicas, especialmente en lo que respecta a la clase social que discrimina a los ciudadanos en Medellín. ${ }^{44}$ Medellín, entre 1985 y 1996, se expande hasta ocupar por completo los pocos reductos sin urbanizar en las vertientes suaves, tanto en la ladera occidental como la oriental, lo que equivale a la incorporación de un $18 \%$ más de suelo, aproximadamente. Lo relevante, además de lo ya mencionado, es que en este mismo período la ciudad emprende un desplazamiento del centro de representación comercial y financiera del núcleo original al suroriente, sector tradicionalmente ocupado por la élite y las familias ricas de Medellín.

Medellín, a partir de 1999, adopta un Plan de Ordenamiento Territorial en el que se asume como modelo de ocupación el crecimiento hacia adentro, ante la escasez de suelo, dentro de un valle estrecho totalmente ocupado. Tal política se enfrenta con la realidad de un paisaje urbano fragmentado en escenas sociales, económicas y culturales muy diversas, emplazadas en los lugares en los que hallaron opciones de desarrollo y supervivencia.

En la siguiente década, el Plan de Ordenamiento Territorial parece habilitar suelos para la nueva urbanización, sin embargo, los instrumentos de gestión se emplean para continuar la expansión de la ciudad sobre sus laderas, prueba de ello es que el dominio urbano sobre el territorio se incrementa un $25 \%$ en el 2006, respecto al área ocupada en 1996, año en el cual el índice no superaba el 18\%.

\footnotetext{
${ }^{44} \mathrm{La}$ estratificación socioeconómica es el instrumento técnico que permite clasificar la población de los municipios y distritos del país, a través de las viviendas y su entorno, en estratos o grupos socioeconómicos diferentes. Se realiza, principalmente, para cobrar los servicios públicos domiciliarios con tarifas diferenciales por estrato y para asignar subsidios en esta área. De esta manera, quienes tienen más capacidad económica pagan más por los servicios públicos y contribuyen para que los estratos bajos puedan pagar sus tarifas. (DANE, Departamento Administrativo Nacional de Estadística)
} 
Ilustración 23. Las seis zonas administrativas del área urbana de Medellín

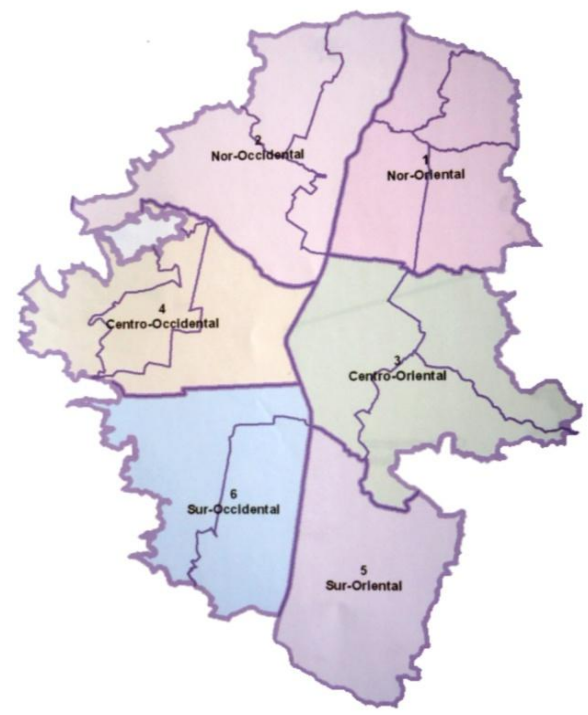

Fuente: Municipio de Medellín, 2010.

Ilustración 25. Unidades geomorfológicas del suelo de Medellín

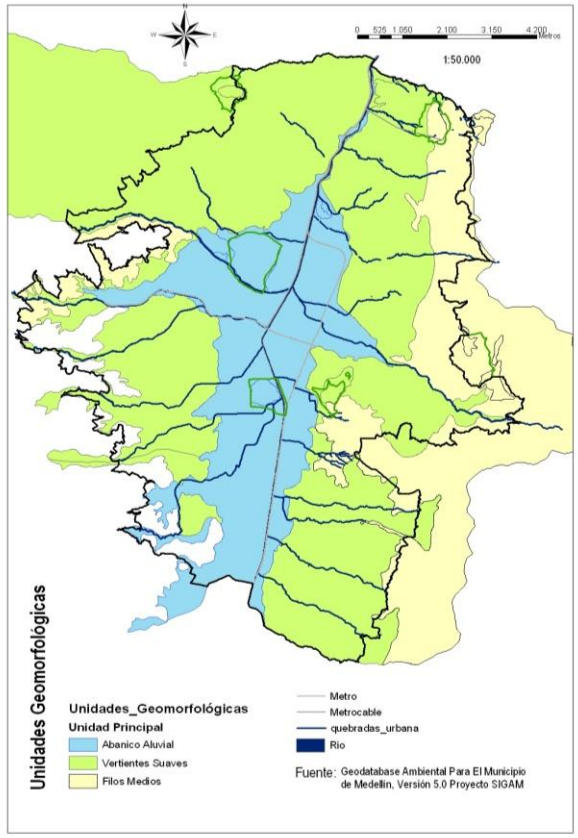

Fuente: Sistema de Gestión Ambiental de Medellín.
Ilustración 24. Estratos socioeconómicos predominantes por barrio en Medellín

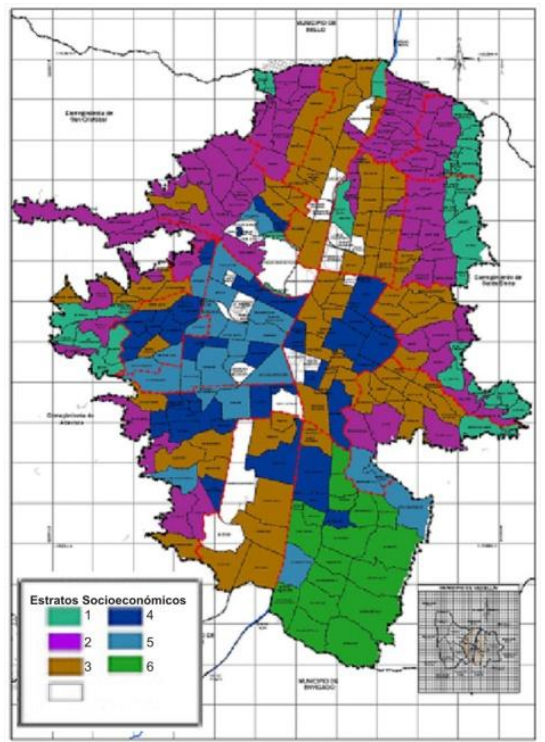

Fuente: Municipio de Medellín, disponible en: http://www.medellin.gov.co/irj/portal/medellin

Ilustración 26. Oferta inmobiliaria de Medellín y sus alrededores

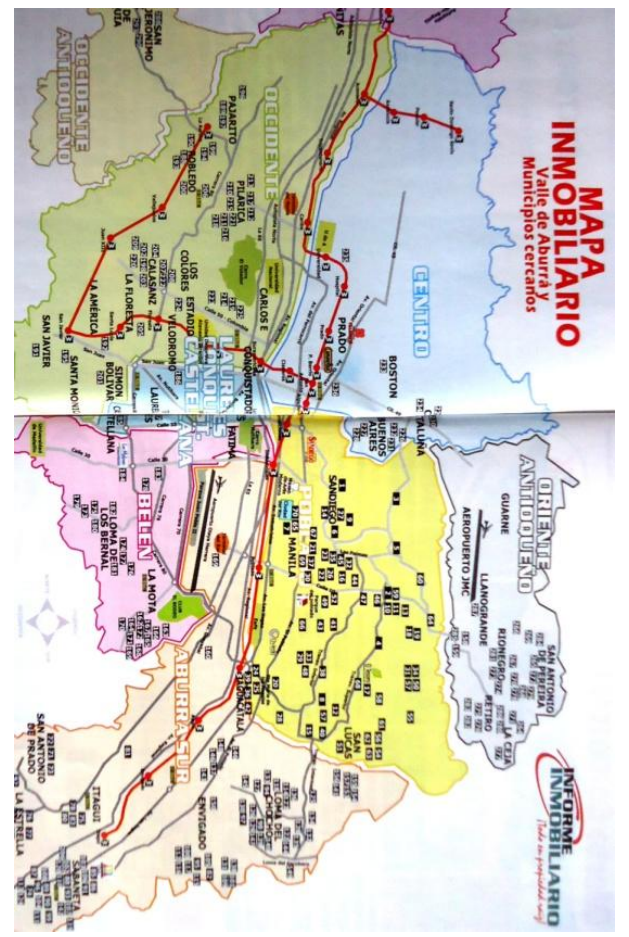

Fuente: Informe inmobiliario, mayo de 2011. 

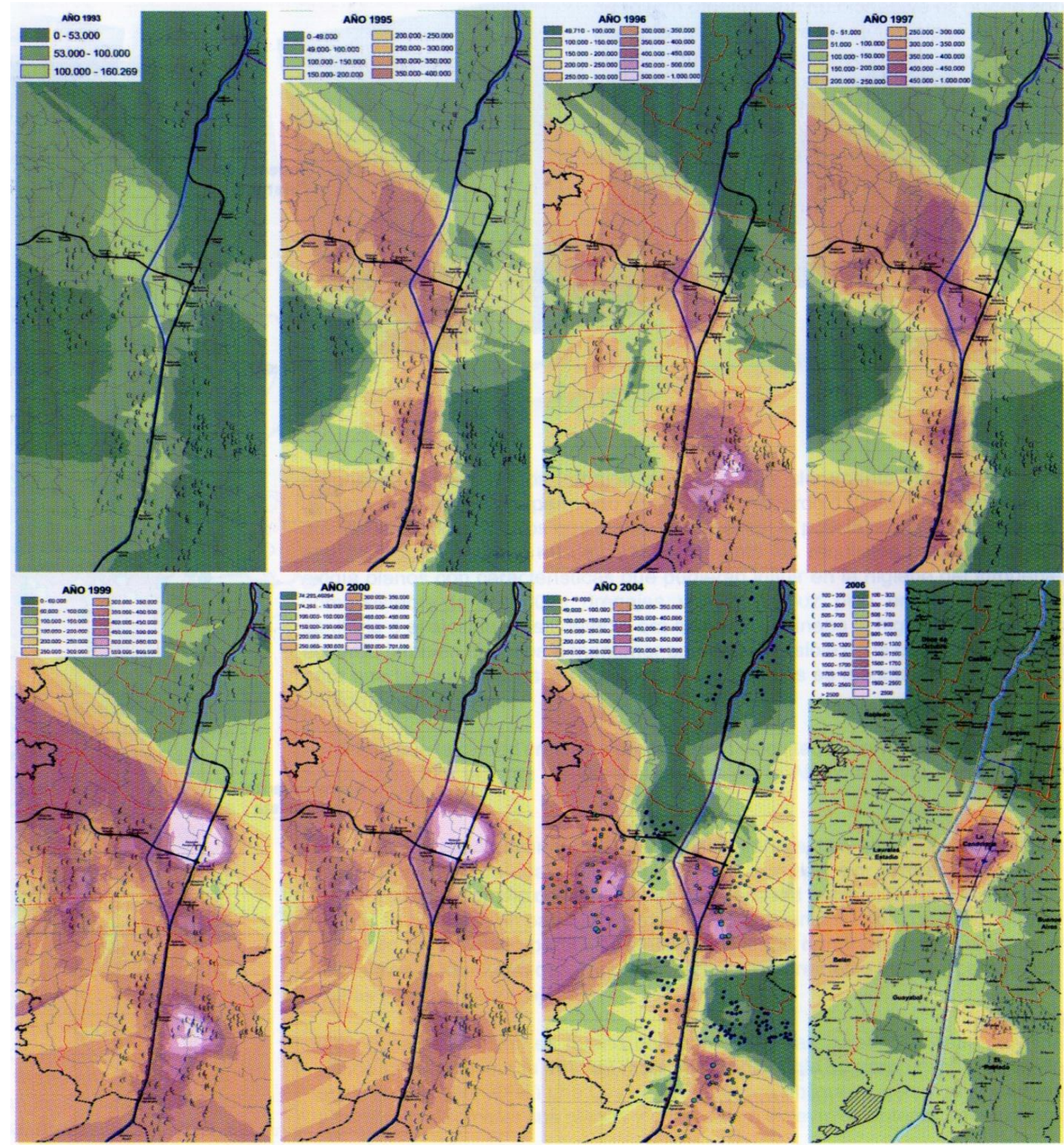

Fuente: estudio valor del suelo. Lonja Propiedad Raíz de Medellín y Antioquia.

Aún así, los nuevos estratos narrativos del paisaje urbano se estiran sobre el territorio, no sin tener que evitar las colisiones con los estratos narrativos que anteriormente se abrieron espacio. Al contrario, lo que se aprecia es una intencionado choque que los nuevos componentes provocan sobre la estructura de los estratos existentes, en intentos decididos por reterritorializar el paisaje y ocasionar la desterritorialización de otros componentes, que sostienen otros espacios, tiempos e itinerarios. 
Ilustración 28. Identificación de los tipos de borde en la colisión de las placas urbanas de 1985, 1996 y 2006, y de estas con el estrato narrativo actual

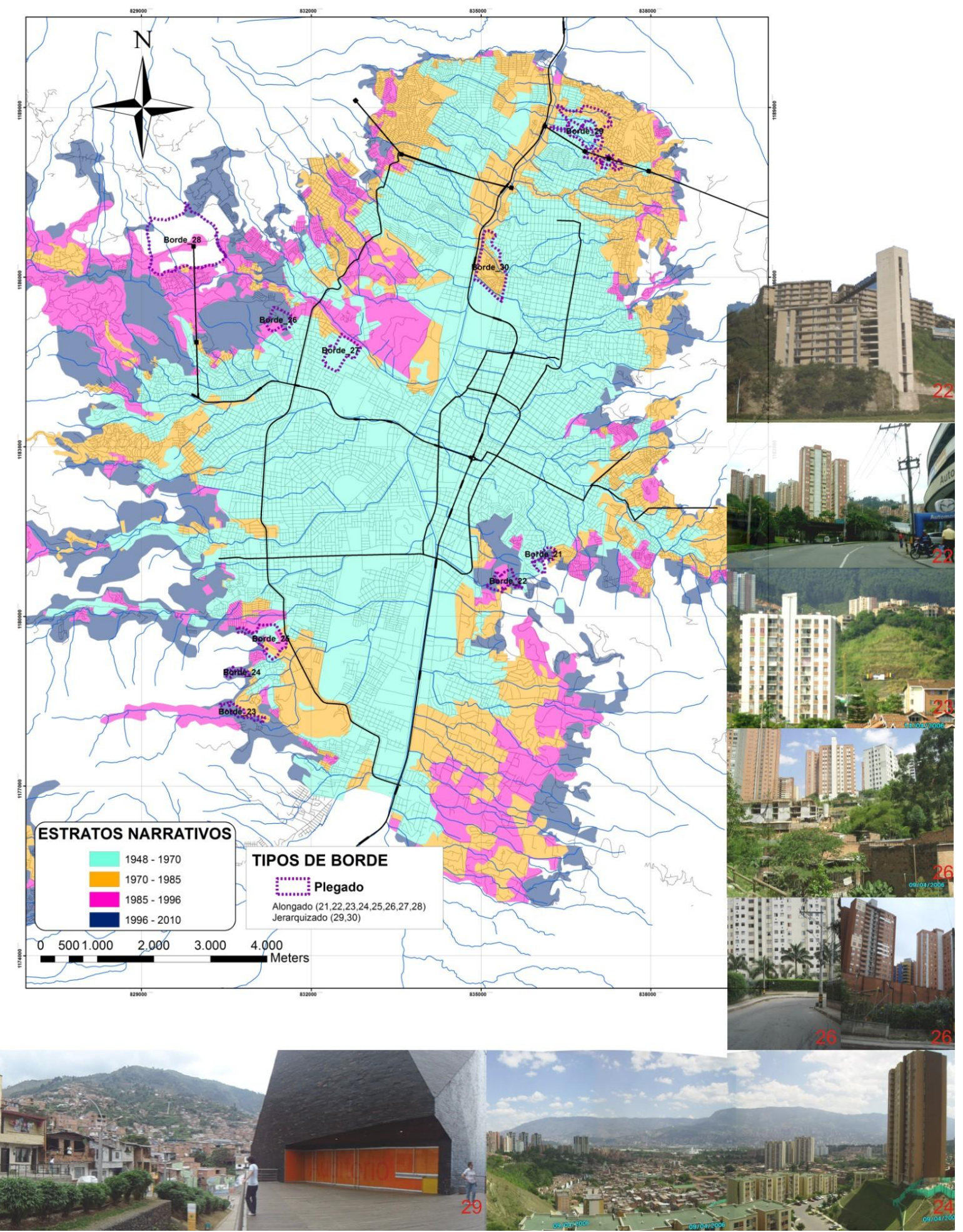

Fuente: ilustración elaborada por el autor con base en la cartografía histórica y el análisis de campo. 
Tabla 1. Relación de la expansión del suelo urbano de Medellín desde 1890 al 2010

\begin{tabular}{ccccc}
\hline $\mathbf{A N} O$ & ÁREA $\left(\mathbf{m}^{2}\right)$ & Porc. crec. & PERÍMETRO $(\mathbf{m l})$ & DIF_ÁREA \\
\hline $\mathbf{1 8 9 0}$ & 1.034 .754 & & $6.743,73$ & $1.034 .753,86$ \\
$\mathbf{1 9 1 0}$ & 3.125 .419 & $202 \%$ & $10.674,96$ & $2.090 .665,00$ \\
$\mathbf{1 9 2 5}$ & 8.717 .849 & $179 \%$ & $42.138,43$ & $5.592 .430,17$ \\
$\mathbf{1 9 4 8}$ & 11.428 .130 & $31 \%$ & $70.938,50$ & $2.710 .281,46$ \\
$\mathbf{1 9 7 0}$ & 56.529 .536 & $395 \%$ & $166.349,19$ & $45.101 .405,43$ \\
$\mathbf{1 9 8 5}$ & 81.323 .743 & $44 \%$ & $194.695,03$ & $24.794 .207,44$ \\
$\mathbf{1 9 9 6}$ & 99.445 .357 & $22 \%$ & $211.233,14$ & $18.121 .613,58$ \\
$\mathbf{2 0 1 0}$ & 123.978 .061 & $25 \%$ & $202.370,14$ & $24.532 .704,37$ \\
\hline
\end{tabular}

Fuente: tabla elaborada por el autor con base en la cartografía histórica de Medellín.

Como apreciamos en los recorridos realizados a través de los estratos narrativos que componen el espacio urbano de Medellín, existe una agitada dinámica de transformación del paisaje, que se revela especialmente en las rupturas que originan los choques entre los distintos estratos narrativos, resultados del proceso de expansión y crecimiento de la ciudad. Dependiendo de las direcciones y la magnitud de las fuerzas de las colisiones, se configuran distintos tipos de paisajes de borde urbano; identificamos dos tipos: los bordes urbanos plegados y los bordes urbanos sedimentados.

\subsection{Los tipos de bordes urbanos plegados o de plegamiento}

Superficies urbanas que obedecen a la configuración de estructuras estables, en un intento de reescribir sobre el texto urbano esquemas que reorienten los itinerarios de los actores urbanos. Este tipo de borde toma unas características particulares en cada uno de los cronotopos ${ }^{45}$ analizados como estratos narrativos del paisaje de Medellín y confrontados con el panorama actual. Nos estamos refiriendo a los estratos que soportan el espacio urbano y a los componentes semióticos que integran cada uno de éstos, productos de múltiples proyectos de resignificación de la ciudad, dirigidos por discursos imperantes en cada fase o época, por grupos que han ostentado y ostentan el poder.

\subsubsection{Borde urbano plegado conglomerado}

Superficies urbanas que se derivan de operaciones sucesivas para la consolidación de sectores, que reorienten los itinerarios de los actores, de posiciones y rutinas de constante agitación, a comportamientos pactados, en donde los actores asumen roles de la pantomima (Sennett, 2002),

\footnotetext{
${ }^{45}$ Entretejido producido por la sociedad en el espacio y el tiempo.
} 
dirigidos por la introducción de componentes semióticos tranquilizadores de la conducta, gracias a su carácter monumental.

El proceso de transformación de lugares que se constituyeron en la escena cotidiana del intercambio y la construcción de lo político, por lugares tranquilizadores, a través de la reducción de la diversidad, y dedicados al espacio ceremonial, donde posar la mirada, como signo de obedecimiento.

En el recorrido de los bordes urbanos entre los estratos narrativos producidos entre 1890, 1910 y 1925 , se pudo constatar que hay sectores que han sido transformados a partir de este tipo de proyecto. Se aprecia, con especial relevancia, en el borde urbano que a principios del siglo XX la ciudad configuró como escenario para el mercado e intercambio cultural, no sólo a nivel local, sino incluso regional y nacional, de una ciudad hasta por aquel entonces caracterizada por su aislamiento.

La plaza de Cisneros (o sector de Guayaquil) fue el ámbito en torno al cual se localizaron la plaza de mercado cubierta, el primer pasaje comercial (Sucre), la estación principal, o de llegada y salida de los ferrocarriles, así como los primeros edificios comerciales. Por la aglutinación de todas estas actividades, el sector de Guayaquil se convirtió en el lugar para la manifestación popular, y el escenario político de mayor representación. Pero también adquirió el papel de ser el sitio donde se practicaba el comercio, se compartía el café y la charla entre diversos actores urbanos (el fango de Baudelaire como lo señala Berman, 1991), en donde tenían lugar todas y cada una de las escenas más corrientes de lo urbano.

En el sector de Guayaquil, especialmente a los alrededores de la Plaza de Cisneros, la actividad comercial fue apoderándose de las rutinas que a diario realizaban las gentes en este escenario urbano convulsionado. En este lugar de la ciudad las personas advertían una libertad de acción que no experimentaban en ningún otro sitio urbano, pues apreciaban que podían ir a cualquier parte, y que todo lo que al parecer existía en el mundo corriente, allí se reunía, abriendo un cúmulo de posibilidades creativas en la experiencia urbana.

Llegada la década de los cincuenta, en el siglo XX, el Plan Regulador de Wiener y Sert plantea la relocalización de los espacios del poder local, regional y nacional justo al lado de las escenas que se mantenían en efervescencia en los alrededores de la Plaza de Cisneros y en todo el sector de Guayaquil. Y si antes la élite observaba cómo estos lugares salieron de su control, con las nuevas pretensiones ahora los juicios morales tomaban mayor repercusión. ${ }^{46}$

46 “(...) resolver el problema del Guayaquil de ese entonces, el cual había tenido en estado de alerta a las autoridades municipales desde mediados de los años cincuenta, debido a que este centro popular albergaba un comercio desordenado en el que convivieron las actividades formales con toda clase de ventas callejeras y otras actividades de la economía de subsistencia. El sector ocupado por una serie de edificaciones viejas, en las cuales pulularon los bares y las pensiones que servían de asiento a los habitantes de menores recursos económicos de la Ciudad. Allí se generaba un constante desorden que le ocasionaba graves traumatismos al funcionamiento del transporte público de la Ciudad. Este ambiente no favorecía los intereses de organizar el centro de la Ciudad y sobre todo los intereses de agrupar todas las dependencias administrativas en el sitio conocido como La Alpujarra (García, 2000:203). 
Foto 31. Plaza de mercado cubierta y Estación Central del Ferrocarril, 1959

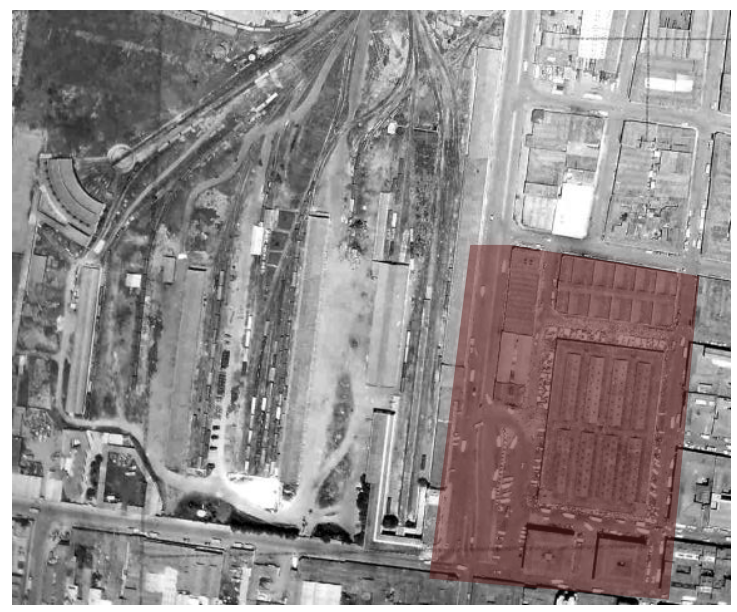

Fuente: Catastro Municipal.
Foto 32. Edificios administrativos en antiguo sector de ferrocarriles, 1975

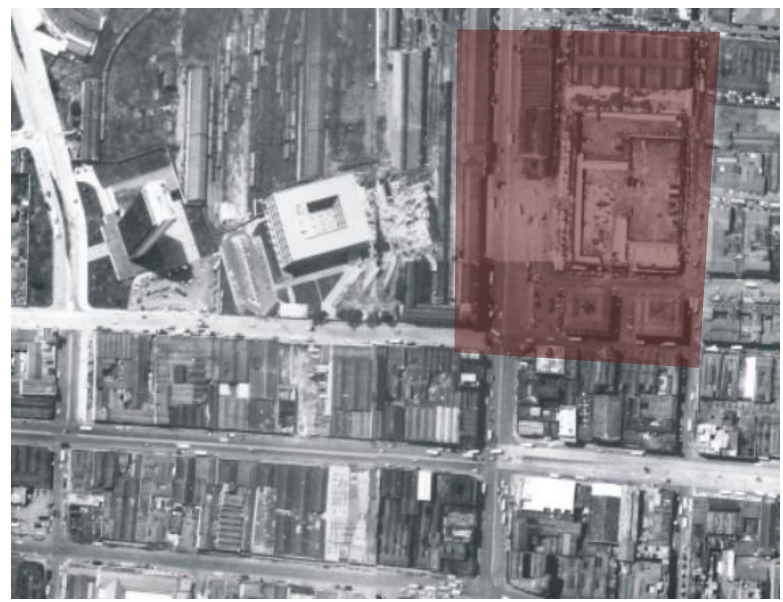

Fuente: Catastro Municipal.

Foto 33. Sector Administrativo La Alpujarra, 1994

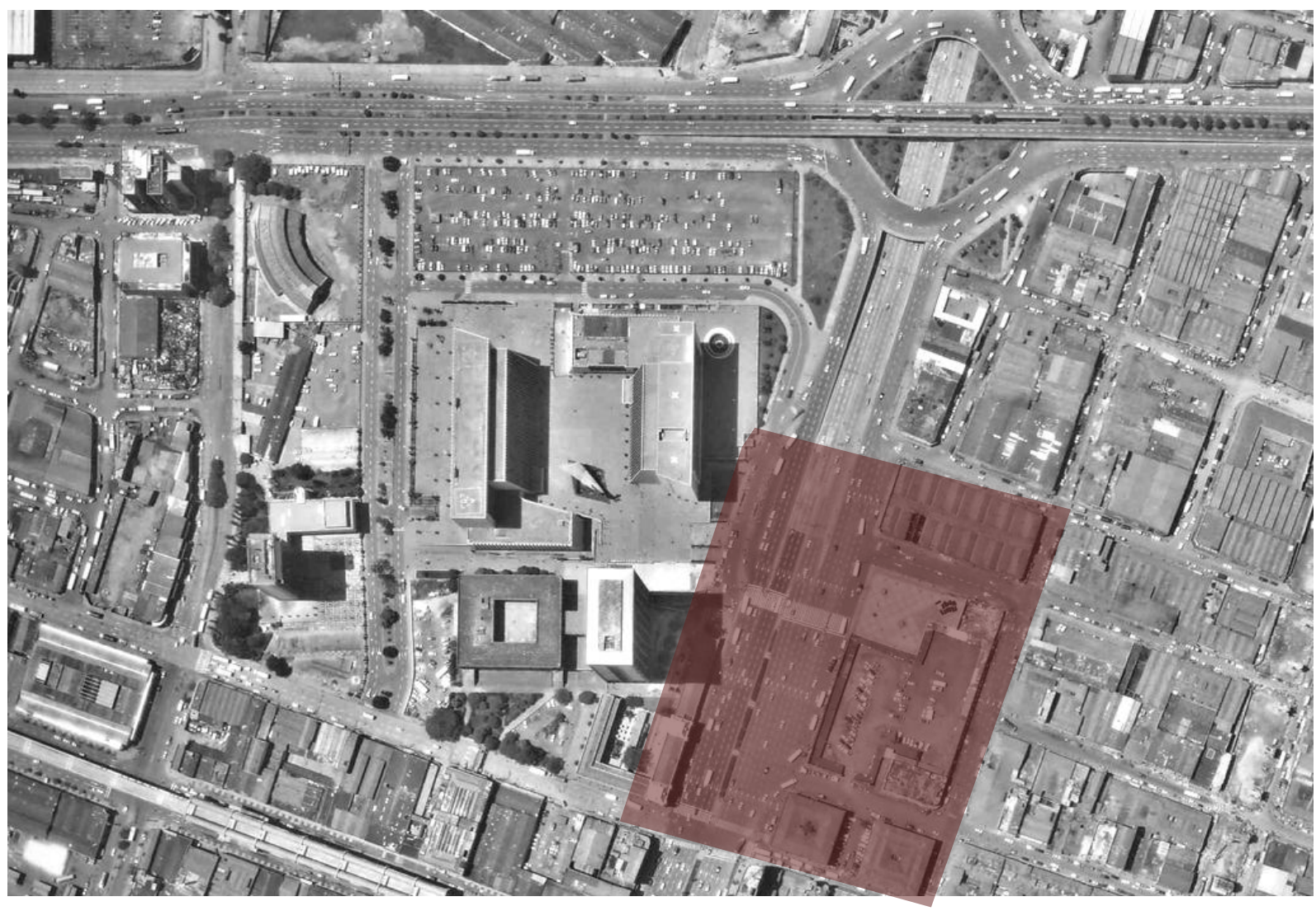

Fuente: Catastro Municipal. 
Foto 34. Plaza de Cisneros

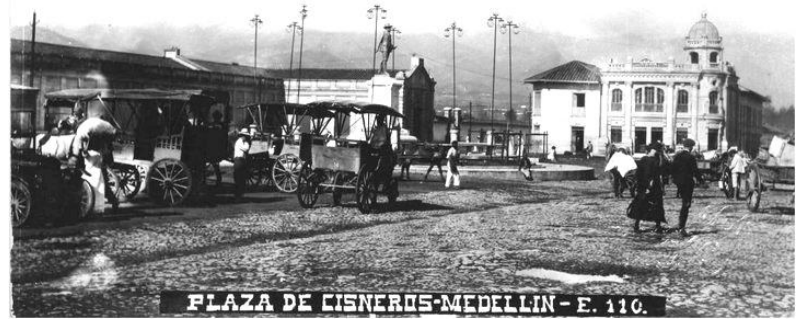

Fuente: Escovar, ca. 1910.

Foto 36. Manifestación en la Plaza de Cisneros

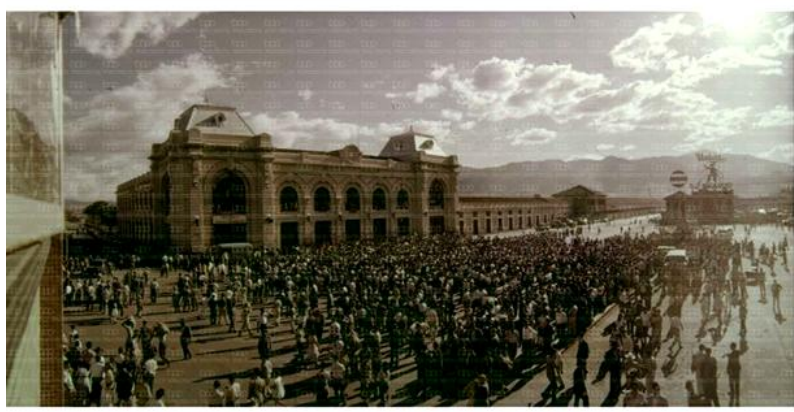

Fuente: Carvajal, ca. 1950.

Foto 38 A las fueras del Mercado Cubierto

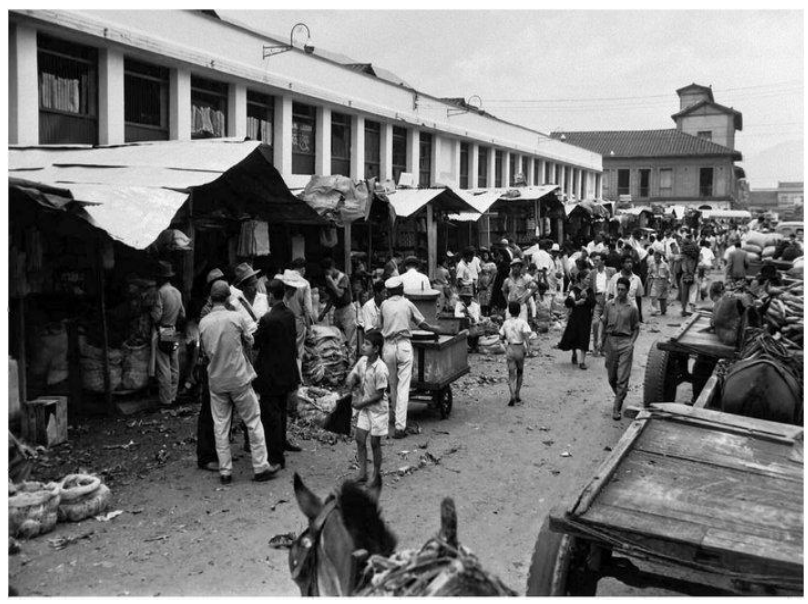

Fuente: Diego García, ca. 1960.
Foto 35. Plaza de Cisneros. Edificio Tobón Uribe

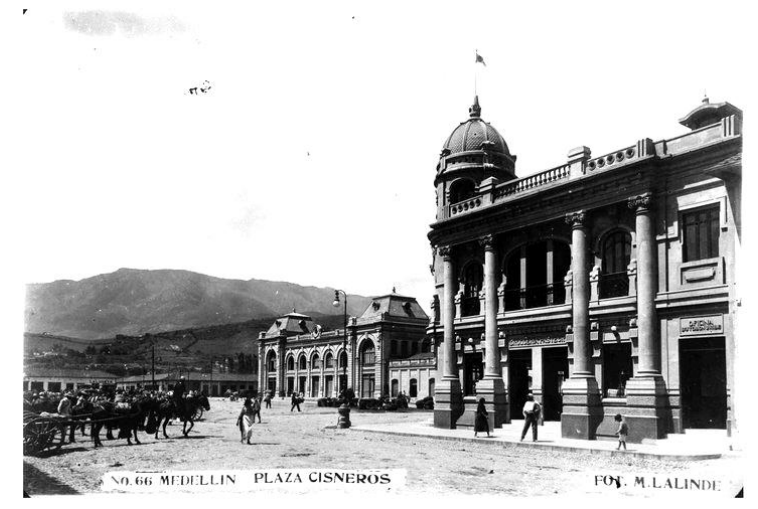

Fuente: Lalinde, ca. 1930.

Foto 37. Mercado Cubierto

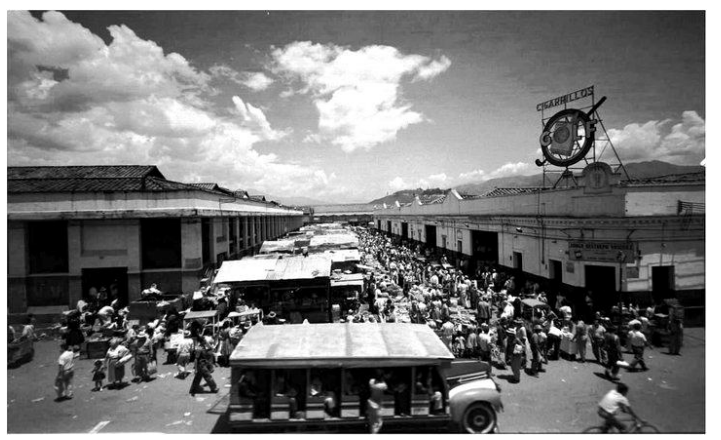

Fuente: Carvajal, ca. 1964.

Foto 39. Imagen aérea de la Plaza de Cisneros

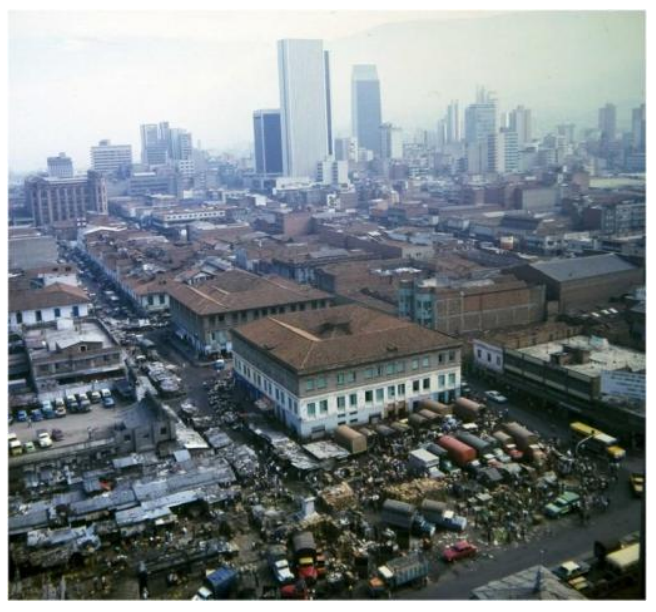

Fuente: Horacio Gil, ca.1982. 
Los moralistas y las personas de cultura tacharán estos logros urbanos populares de bajos, vulgares, sórdidos, vacíos de contenido social o espiritual (Berman, 1991:160).

Se inicia así un proceso de reterritorialización del centro en su costado sur con la construcción del centro administrativo La Alpujarra en 1983, en las áreas que dejaron de funcionar para el sistema de ferrocarriles regionales y nacionales a partir de 1961. Con la incorporación de componentes semióticos de carga monumental, se propone moldear el espacio y el tiempo en una escenografía sometida a un nuevo lenguaje, cargada de un orden ejemplarizante.

Culminada la construcción del centro administrativo La Alpujarra, su ahora vecina, la Plaza de Cisneros, con su cúmulo de actividades en constante agitación, se constituía en una escena incomoda que suscitó su desplazamiento (desterritorialización) en el borde noroccidental de la zona núcleo de la ciudad con el río, convertido en eje vial metropolitano del Valle de Aburrá, gracias también a las indicaciones del Plan Regulador de 1948. Trasladada la actividad principal de esta ágora popular, el mercado, los componentes semióticos que lo acompañaban, quedaron desarticulados de un relato que les daba sentido a su posición. Estas situaciones incómodas han intentado ser resueltas con el borrado de algunos componentes, esperando con esto evitar la restauración de la memoria y el exilio definitivo de los itinerarios que estos elementos configuraban.

\section{Foto 40. Pasaje Sucre demolido en enero de 2003 en aparente marco ilegal}

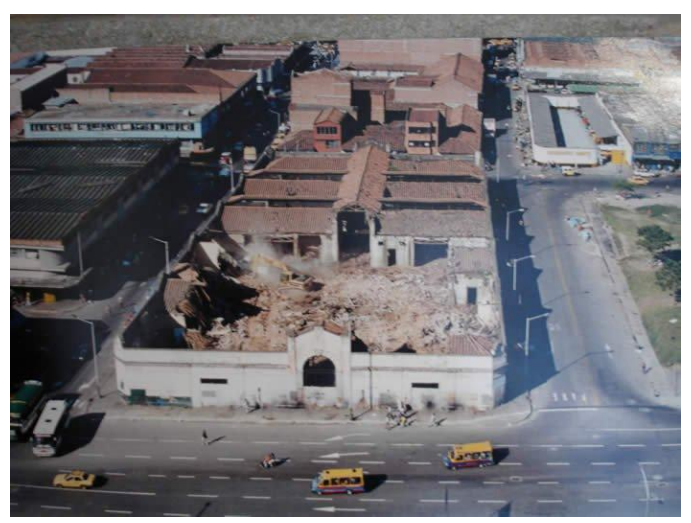

Fuente: tomado de

http://www2.epm.com.co/bibliotecaepm/quienes_somos/ historia.htm

\section{Foto 41. Biblioteca EPM y La Plaza de La Luz sustituyendo el pasaje Sucre y la Plaza de}

\section{Cisneros}

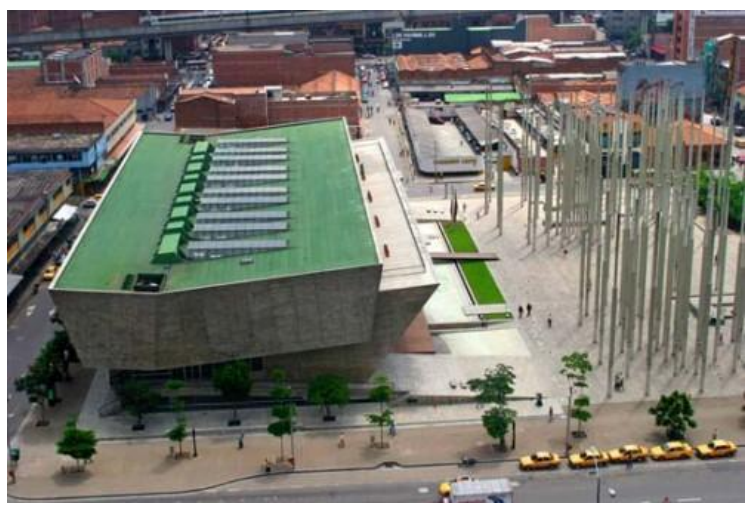

Fuente: tomado de

http://sancheztaffurarquitecto.wordpress.com/page/26

/?archives-list\&archives-type $=$ tags

\subsubsection{Borde urbano plegado integrado}

Son las superficies urbanas que se desprenden de acciones que procuran la reterritorialización de corredores urbanos, bajo intentos de conectar distintas centralidades de representación del poder. Esta situación se da especialmente alrededor de sectores que han tomado una alta dinámica de filigrana urbana, es decir, de actividad intensa, mostrándose como un escenario azaroso frente a las prerrogativas de la planificación urbana.

La dirección de las acciones sobre estos corredores urbanos despliega una nueva modulación del espacio y el tiempo, de tal manera que se pueda efectuar una vigilancia constante, para intentar anular cualquier espontaneidad de los actores urbanos. Tales propósitos se realizan también para cautivar el 
interés de sectores formales de la economía, para que emprendan proyectos inmobiliarios que, introduciendo nuevos componentes semióticos, recolonicen sectores dejados por fuera del imaginario comercial.

La nueva modulación del espacio y del tiempo implica a los actores urbanos y reorienta sus prácticas en la movilidad. Frente al torbellino de circulaciones, las nuevas intervenciones plantean ritmos consumados, en sendas cuidadosamente diseñadas para el desenvolvimiento de coreografías urbanas, en donde la confrontación de lo diverso no tenga lugar, o si se da, quede conjurada por el enmascaramiento de escenografías, que insisten en mostrar una ciudad perfecta.

El recorrido realizado entre los bordes de los estratos narrativos de 1890, 1910 y 1925, confrontados en la lectura del panorama actual, indica que este tipo de bordes plegados aparecen entre los ejes que han sido reforzados como conectores, entre el núcleo de la ciudad y las centralidades de sectores residenciales, configurados en gran medida por actuaciones informales, o que a pesar de su origen formal fueron capturados en el proceso de transformación de la ciudad por dinámicas insurgentes.

Estos mismos corredores urbanos, en el intento de ser re-activados, también atraviesan sectores intersticiales, en los que fueron dejándose objetos abandonados porque dejaron de ser útiles en el proceso de transformación de la ciudad. Ahora hacen parte de los trayectos estandarizados, requeridos como instrumento para instaurar una identidad común y homogeneizante. Estos corredores se constituyen en los empalmes identificados como sitios de operaciones macrosemióticas (Delgado, 2010), es decir, galerías de nuevas dotaciones simbólicas.

Corredores urbanos como la calle Carabobo, el eje norte principal, que conecta el núcleo de la ciudad con los sectores colonizados en las primeras etapas de expansión de la ciudad, viene sufriendo como borde este tipo de transformación. Desde la planificación urbana y el diseño urbano como tal, se pretende hacer de Carabobo un eje de carácter patrimonial, a través de operaciones de codificación que procuran un ejercicio de sincronía entre los objetos que aparecen en el ahora nuevo recorrido de la identidad.

El antiguo corredor del ferrocarril, que tras el cierre del sistema en 1961, se convierte en una de las arterias de la movilidad urbana, es intervenido como borde periférico entre el núcleo urbano central y el eje longitudinal del río Aburrá, para integrarlo a la centralidad. Las antiguas áreas dedicadas a la industria, y por los barrios que albergaban a sus operarios, vienen siendo sustituidas por los nuevos productos comerciales del sector inmobiliario y por un renovado sistema de transporte.

Foto 42. Tranvía por la carretera norte Carabobo

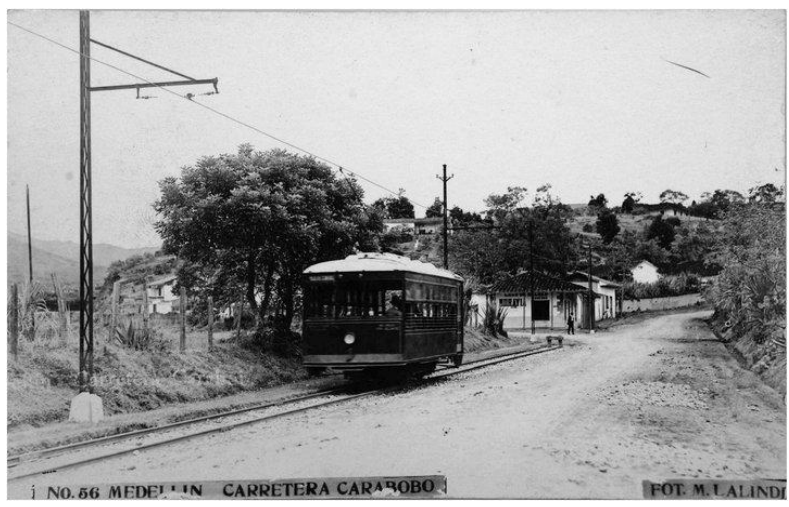

Fuente: Lalinde, ca. 1922.
Foto 43.Sectores periféricos por Carabobo

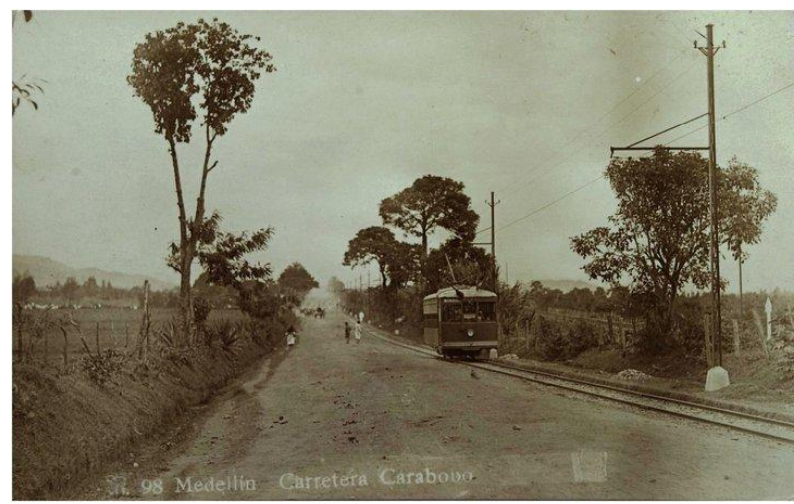

Fuente: Lalinde, ca. 1922. 
Foto 44. Estación del bosque. Ferrocarril

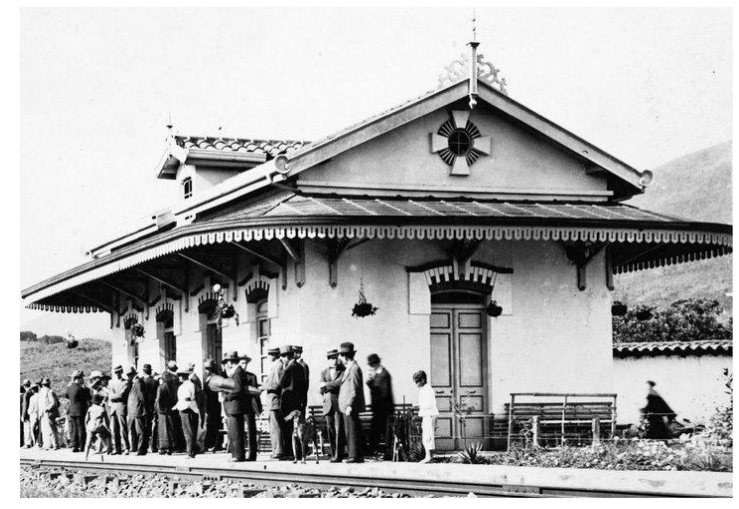

Fuente: Rodríguez, ca. 1910

Foto 46. Arte ambulante

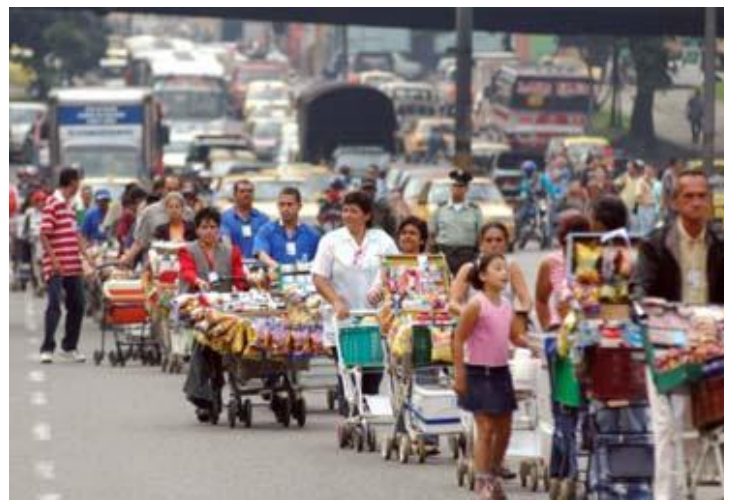

Fuente: Claudia Múnera, 2007.

Foto 48. Calzadas para el Metroplús avenida Ferrocarril

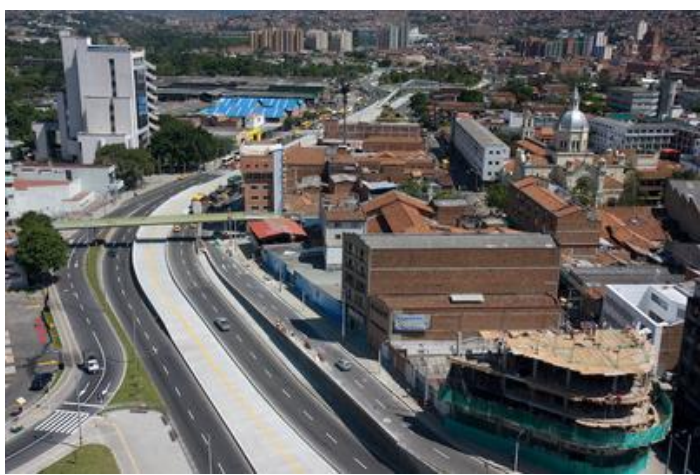

Fuente: Periódico El Colombiano, Medellín 2010
Foto 45. Estación del bosque. Monumento vacío

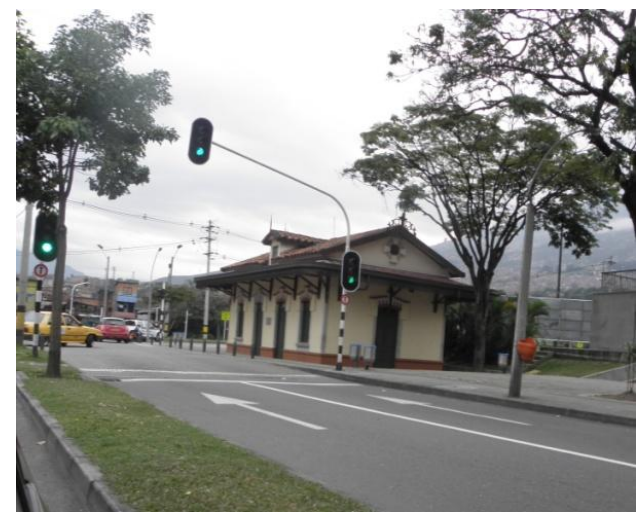

Fuente: César Salazar, 2012

Foto 47. Carabobo en verano

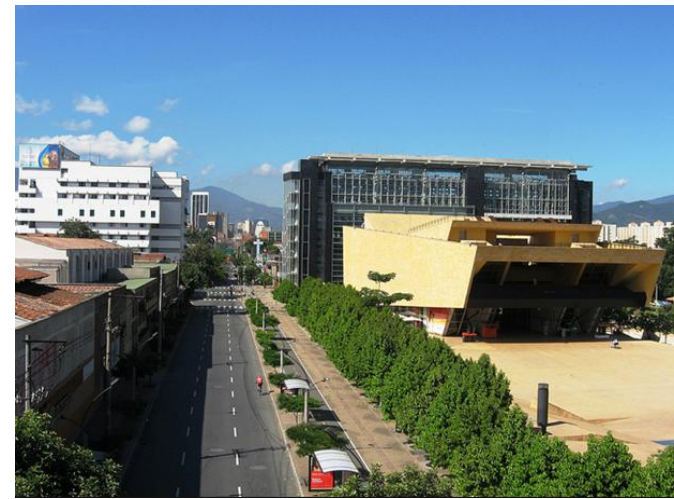

Fuente: Dairo Correa, 2011 (Flickr:

http://www.flickr.com/photos/dairocorrea/sets/721576025043 69004/).

Foto 49. Calzada en construcción del Metroplús por el barrio El Chagualo

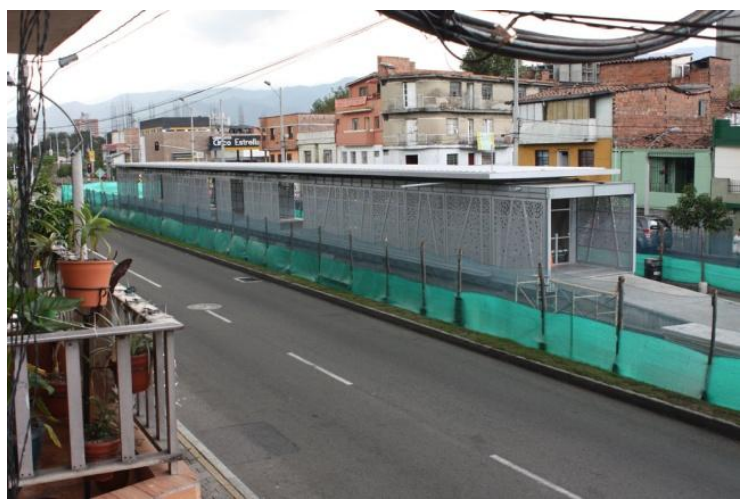

Fuente: Periódico El Colombiano, Medellín 2010. 


\subsubsection{Borde urbano plegado aglutinante}

Son las superficies, o los nuevos pliegues urbanos, producto de intensas acciones de transformación de áreas que venían alejándose del rol estructurante, en la construcción de una identidad común en la ciudad. Su propósito es hacer de estas áreas, en las que vienen generándose un encuentro de texturas urbanas de compleja mixtura, lugares de conversión que garanticen el proceso de la reconstrucción de identidad ciudadana, proyecto de los sectores influyentes y con poder.

Este tipo de pliegue pretende recrear nuevas centralidades a través de operaciones que intentan modificar los imaginarios de los actores, alterando los itinerarios que estos trazan en distintas direcciones. Para tal efecto se emplean escenografías seductoras (Delgado, 2010) que insisten en instaurar un nuevo culto urbano, en espacios donde la gente siente la libertad de su cuerpo; sensación que se produce con la incorporación de grandes volúmenes abiertos. Producen un efecto de apaciguamiento de las multitudes (Sennett, 2002).

En el recorrido realizado entre los estratos narrativos del paisaje, producidos entre 1890, 1910 y 1925 , confrontados con la experiencia que ofrece el panorama actual, es un borde en el que se distingue este tipo de transformación. Corresponde a un sector de la ciudad en el que a partir de finales de la década de 1910 fueron localizados algunos equipamientos recreativos, en su momento artefactos culturales de disipación de los conglomerados urbanos, conformados por los obreros y empleados de oficinas y almacenes de la pujante economía de comienzos del siglo XX.

El Bosque de la Independencia, escenario de las primeras escenas burguesas en la ciudad, fue quedando apresado por la configuración del contexto urbano con el transcurrir de las décadas, hasta perder su rol protagónico en la estructuración de la identidad común, proyecto de la élite de la ciudad. A pesar de la construcción de nuevos escenarios recreativos, circunvecinos al Bosque, este sector asumía cada vez, con mayor fuerza, una condición de frontera, entre la ciudad que se ceñía a las reglas de la formalidad y esa otra ciudad que paralelamente construían desde otras lógicas los inmigrantes del mundo rural.

El corredor ferroviario había reforzado este carácter en la primera mitad del siglo XX, y aun a pesar de su desaparición, las morfologías que se adaptaron a su alrededor mantuvieron la persistencia de las trazas de esta memoria urbana. Este lugar constituido en un nudo que no logran deshacer los planteamientos ideológicos dominantes en la ciudad, ahora es un laboratorio de espacios protéticos (Delgado, 2007) a partir de los cuales se intenta controlar los mapas mentales de todos los ciudadanos.

La introducción sucesiva de componentes semióticos, de gran impacto visual, da inicio a un proceso de aglutinamiento de franjas con una alta carga simbólica, debido a la diversidad cultural, que ante la falta de comprensión, la planificación urbana reduce como lugares donde es necesario efectuar la purificación del territorio (Delgado, 2010). Con este enfoque se intervienen segmentos urbanos, reescritos a la manera de acciones monumentales, que direccionan las trayectorias de los actores urbanos.

Este tipo de acción ha tomado tal fuerza que ya se ha convertido en una política para rediseñar lugares públicos, con la que se pretende resolver las fragmentaciones y las discontinuidades del tiempo 
narrativo elegido por los grupos de poder local. Todo esto bajo la buena pero ingenua intención de resolver los problemas sociales a través de la redefinción de los lugares de la memoria, y no intentando realmente modificar las estructuras sociales que muestran una evidente asimetría en la ciudad.

Foto 50. Jardín Botánico, antiguo Bosque de La Independencia

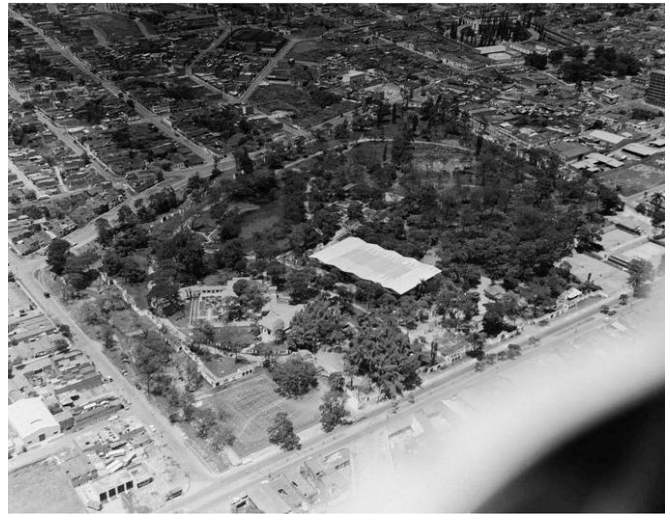

Fuente: Carvajal, 1972.

Foto 52. Parque de los deseos

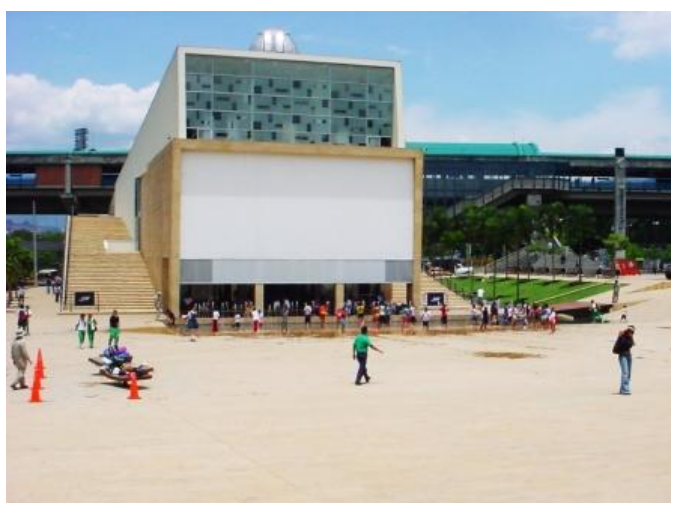

Fuente: Propuestas in_consultas, disponible en: http://sancheztaffurarquitecto.wordpress.com/page/26/ ?archives-list\&archives-type=tags. Consulta: $30 \mathrm{de}$ enero de 2012
Foto 51. Parque Explora de la ciencia y la tecnología

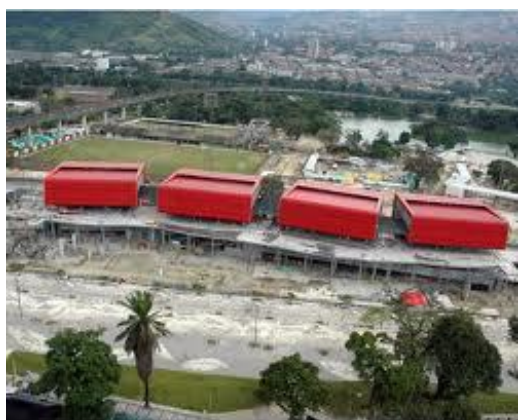

Fuente: Propuestas in_consultas, disponible en: http://sancheztaffurarquitecto.wordpress.com/page/26/ ?archives-list\&archives-type=tags. Consulta: $30 \mathrm{de}$ enero de 2012

Foto 53. Intervenciones al norte del núcleo de la ciudad

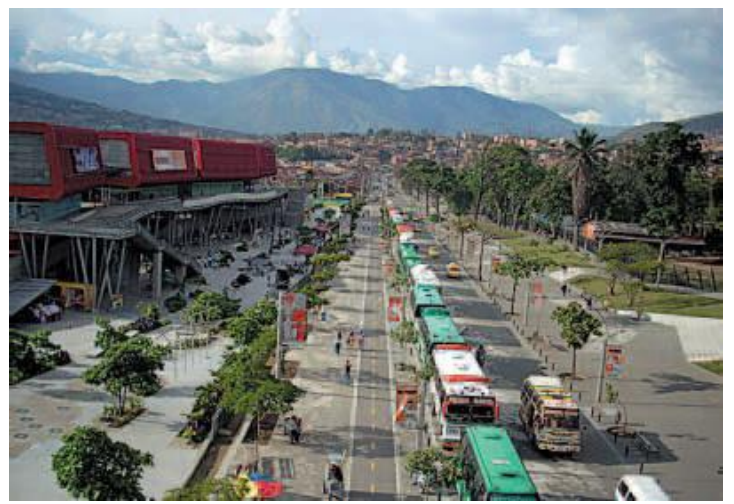

Fuente: Propuestas in consultas, disponible en: http://sancheztaffurarquitecto.wordpress.com/page/26/ ?archives-list\&archives-type=tags. Consulta: $30 \mathrm{de}$ enero de 2012

\subsubsection{Borde urbano plegado jerarquizado}

Superficies narrativas que en el proceso de crecimiento de la ciudad se desarrollaron alejadas de los centros de representación del poder, o que a pesar de estar próximas a los mismos, implementan estrategias de enclave, ya que fueron, y en algunos casos aún son, dominadas por sectores muy específicos y determinados de la sociedad. Varias superficies de este tipo han sido transformadas por 
operaciones de gran impacto, provenientes del estado, que incorporando componentes semióticos, caracterizados por su monumentalidad, intentan incluirlas como parte del sistema de lugares centrales de la ciudad.

Este tipo de superficies fueron apareciendo en diversos sectores de la ciudad, especialmente en las áreas periféricas que se configuran a partir de la expansión urbana de Medellín, en las décadas del cincuenta y del setenta del siglo XX. El incremento del 395\% del área urbana en esa fase de expansión de la ciudad es una muestra clara del reto que se impuso a la planificación y a la gestión de ésta, que a pesar de contar con un Plan Regulador no previó tal índice de crecimiento. Factores externos, como las migraciones campesinas a la ciudad, incidieron especialmente en la incertidumbre del rumbo que tomaba la expansión del área urbana, en buena medida fuera del control de la administración municipal.

Por otro lado, la misma planificación de mediados del siglo XX, y con una fuerte implementación en las décadas del sesenta y setenta, recrea sobre el suelo urbano unas amplias áreas diferenciadas por las funciones que el movimiento moderno insistió en separar. Este es el caso de las zonas industriales, algunas próximas al núcleo de la ciudad, y en directa relación con el corredor metropolitano del río Medellín (o de Aburrá), que en las últimas dos décadas han entrado en un proceso de obsolescencia urbana.

El Plan de Ordenamiento Territorial de Medellín (Acuerdos 062 de 1999 y 046 de 2006) señala para este tipo de sectores de la ciudad unas categorías de tratamiento urbanístico, que enfatizan el nivel de intervención requerido, promoviendo una drástica transformación. Para el caso de los sectores que en la periferia se alejaron de las lógicas propuestas por el sistema de lugares centrales, se propone el "Mejoramiento Integral", ${ }^{47}$ y para la reactivación de los suelos que ocupan la zona industrial en decaimiento, la propuesta es "La Renovación" ${ }^{48 " . ~}$

En el recorrido realizado entre los estratos narrativos que configuran las fases de 1925, 1950 y 1970 se identifican dos casos representativos de este tipo de borde, uno relacionado con los sectores periféricos al núcleo de la ciudad, más precisamente en la comuna 13 al occidente de la ciudad, y el segundo al sur del mismo núcleo en el reconocido sector de los industriales. En el primer caso la operación se realiza a través de la construcción de un "parque biblioteca", objeto de un concurso cuya pretensión de intervenir en estos lugares es imponer un lenguaje que inicie la ordenación de un entorno urbano caracterizado por la informalidad.

47 "Este tratamiento corresponde a las zonas homogéneas identificadas como "Áreas de Desarrollo Incompleto e Inadecuado", donde se localizan los asentamientos humanos en situación de marginalidad y segregación socioespacial, en los cuales se concentra población en situación crítica de pobreza al margen de las oportunidades del desarrollo, con limitaciones de acceso a los bienes y servicios públicos esenciales como la educación y la salud, dando lugar a las bajas condiciones de vida de los habitantes." Acuerdo 046 de 2006 de Medellín, artículo 243

48 "Este tratamiento se asigna a las zonas homogéneas identificadas como "Zonas Deterioradas o en Conflicto Funcional”, y cuyo objetivo es promover importantes transformaciones en zonas que cumplen un papel fundamental en la consolidación del modelo de ordenamiento propuesto por el Plan y en el cumplimiento de los objetivos del mismo y que por razones de deterioro ambiental, físico o social, conflicto funcional interno o con su entorno inmediato, requieren de esta transformación físico-espacial y socioeconómica, para aprovechar al máximo su potencial.” Acuerdo 046 de 2006 de Medellín, artículo 245 
El segundo caso se realiza a través de la incorporación de un museo, contenido en una vieja estructura industrial, reciclada para albergar la nueva función. A pesar de que la operación no es gestionada directamente por el municipio, el instrumento de gestión ${ }^{49}$ adelantado por privados debe ser aprobado por instancias reguladoras, que exigen, para tal efecto, el pago de obligaciones urbanísticas, incentivando la generación de este tipo de equipamientos.

La renovación de una porción del suelo urbano, para la promoción de productos nuevos del sector inmobiliario (vivienda y servicios, principalmente), va acompañada de la erección de nuevos monumentos, que garanticen que la llegada de los nuevos habitantes se mantengan dentro de los esquemas de la ordenación, empleando la tematización de los lugares, conjurando así los comportamientos espontáneos.

Foto 54. Aerofotografía de la centralidad de San Javier, comuna 13, Medellín en el 2004

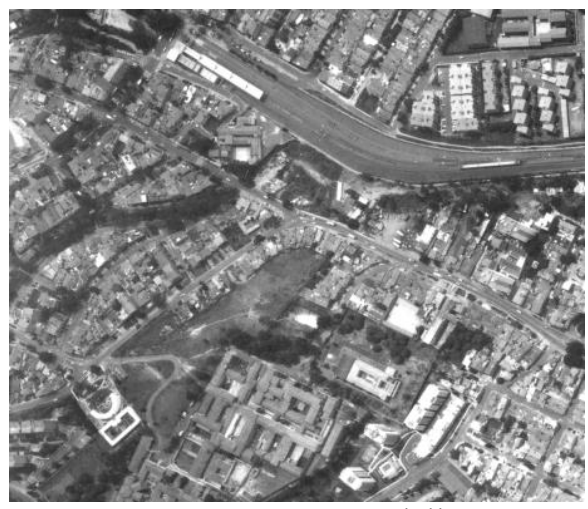

Fuente: Catastro Medellín.

Foto 56. Inserción de la Biblioteca San Javier

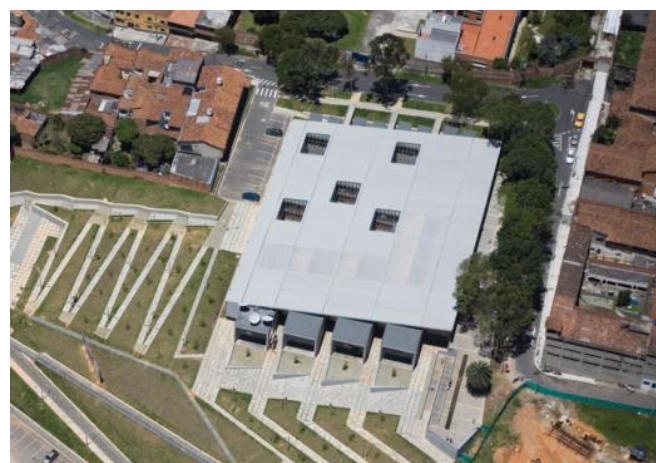

Fuente: Cubiertec, disponible en: www.cubiertec.com. Consulta: enero 30 de 2012.
Foto 55. Aerofotografía de la centralidad de San Javier, comuna 13, Medellín en el 2012

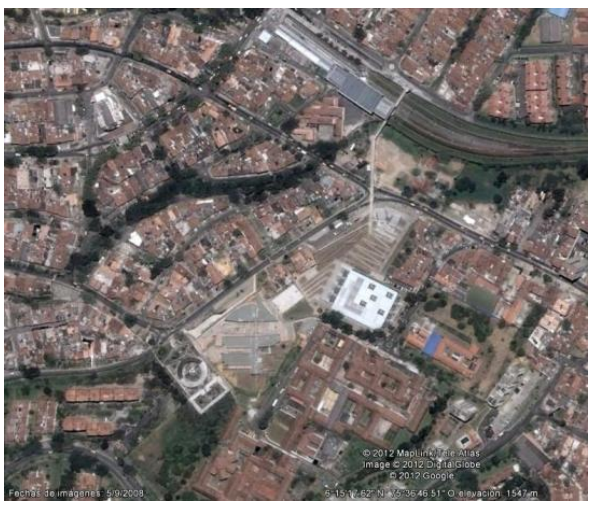

Fuente: Google Earth. Consulta: enero 30 de 2012.

Foto 57. Entorno urbano de la Biblioteca San Javier

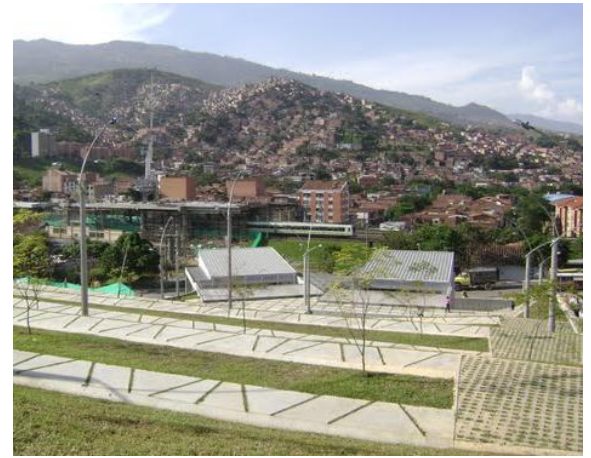

Fuente: Panoramio, Julio Cesar Uribe, 2008.

\footnotetext{
49 "Plan Parcial. Es el instrumento mediante el cual se desarrollan y complementan las disposiciones de los planes de ordenamiento territorial, para áreas determinadas del suelo urbano y para las áreas incluidas en el suelo de expansión urbana, además de las que deban desarrollarse mediante unidades de actuación urbanística, macroproyectos $u$ otras operaciones urbanas especiales, de acuerdo con las autorizaciones emanadas de las normas urbanísticas generales, en los términos previstos en la Ley 388 de 1997”. Decreto 2181 de 2006, artículo 1 , numeral 12
} 
Foto 58. Aerofotografía sector Industriales de Medellín, 2004

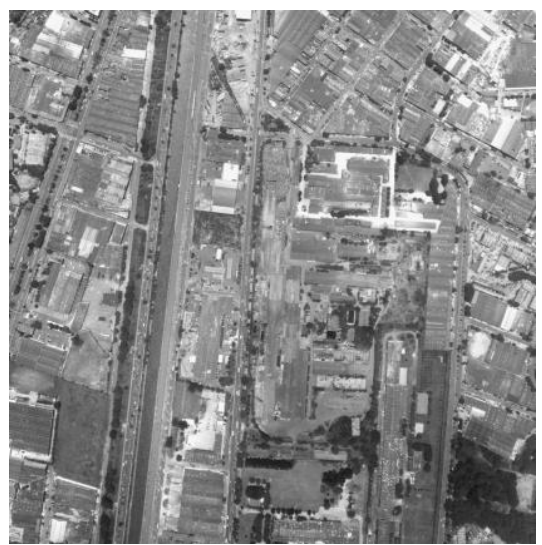

Fuente: Catastro Medellín.
Foto 59. Aerofotografía sector Industriales. Proceso de transformación, 2008

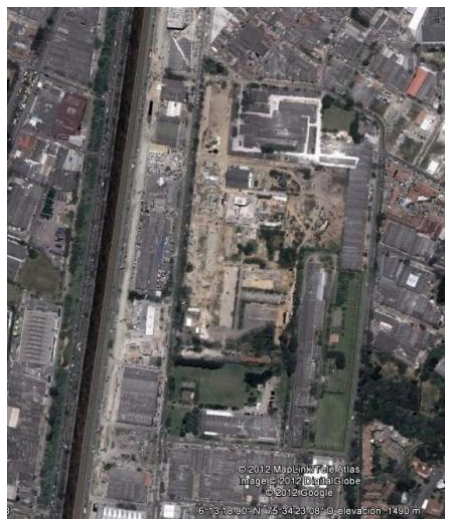

Fuente: Google Earth. Consulta: enero 30 de 2012.
Foto 60. Sector Industriales de Medellín, ca. 1950

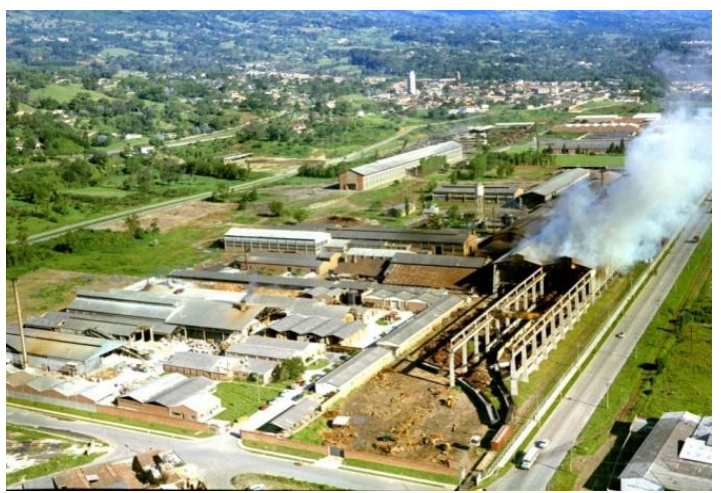

Fuente: Carvajal, ca. 1970.
Foto 61. Taller industrial reciclado para albergar el Museo de Arte Moderno de Medellín

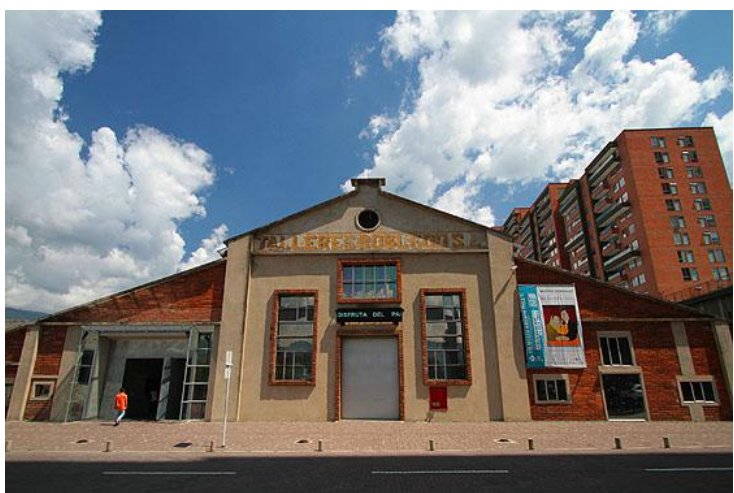

Fuente: I love Medellín, disponible en: www.ilovemedellin.net. Consulta: día, mes, año.

\subsubsection{Borde urbano plegado alongado}

Son las superficies urbanas producto del estiramiento de los estratos narrativos más recientes del proceso de expansión de la ciudad. Este tipo de intervención se viene ejerciendo sobre áreas rústicas (periféricas a la ciudad), o aledañas a sectores que venían siendo consolidados por procesos con un alto nivel de autogestión comunitaria, algunos de estos cargados de imágenes negativas dentro del imaginario colectivo de los ciudadanos.

La estrategia empleada por este tipo de superficies, para lograr la reterritorialización, es la incorporación de nuevas figuras que contrastan abiertamente con las características del territorio, objeto de recolonización urbana. El propósito de anexar nuevas imágenes al territorio se da para 
inducir a un proceso de aculturación y de dominio, particularmente sobre aquellos sectores de la ciudad en donde la informalidad viene consolidando alternativas de construcción de lo urbano.

Este tipo de borde urbano se caracteriza por mostrar una acelerada dinámica de transformación, que ocasiona en los sectores periurbanos una deformación de sus cualidades urbanas y paisajísticas, ya que la introducción de los nuevos componentes no alcanzan a acomodarse a las condiciones infraestructurales del sitio. La insistencia de este tipo de acciones de estirado sobre el paisaje urbano, en contra de fuerzas que siguen otro tipo de lógicas, produce la de-formación tanto del espacio como del tiempo, y por tanto trastorna los itinerarios de los actores urbanos.

En el recorrido efectuado a través de los estratos narrativos del paisaje urbano de Medellín, se identificaron la aparición de este tipo de borde sobre los sectores periurbanos, en proceso de configuración desde los años 1970 y 1985, especialmente. En los últimos veinte años, el sector inmobiliario ha apostado por la promoción de viviendas unifamiliares y multifamiliares bajo la configuración de morfologías cerradas, sin distinguir las características sociales, económicas, culturales e incluso geomorfológicas en los lugares que sirven de emplazamiento.

Foto 62. Procesos de expansión al suroccidente de Medellín, 2004

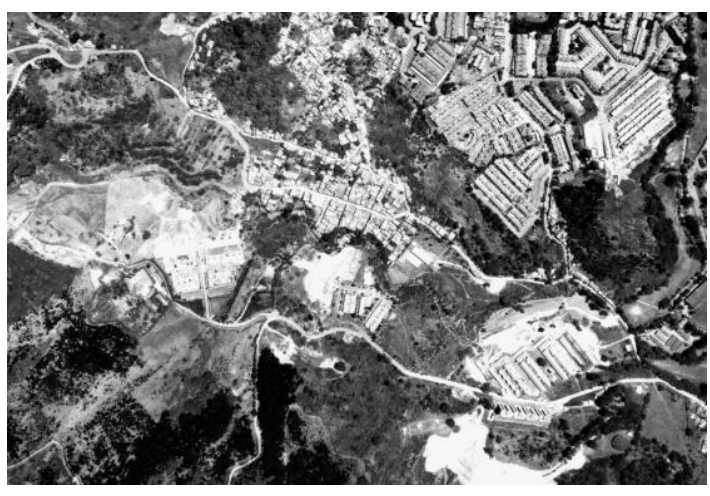

Fuente: Catastro Medellín.

Foto 64. Áreas incorporadas al suelo urbano al suroccidente de Medellín

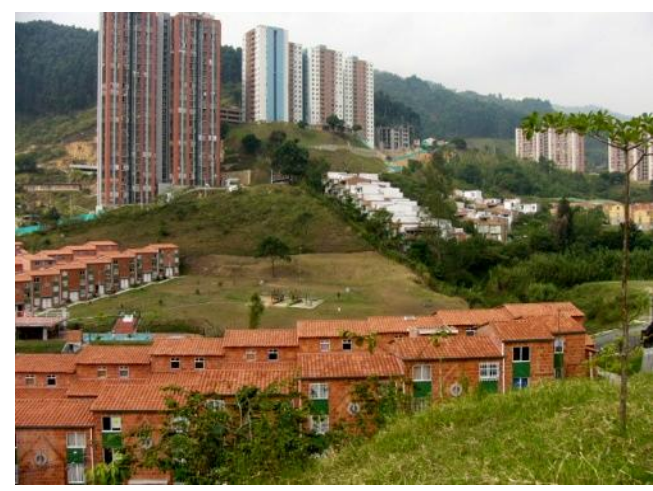

Fuente: César Salazar, 2010.
Foto 63. Procesos de expansión al suroccidente de Medellín, 2007

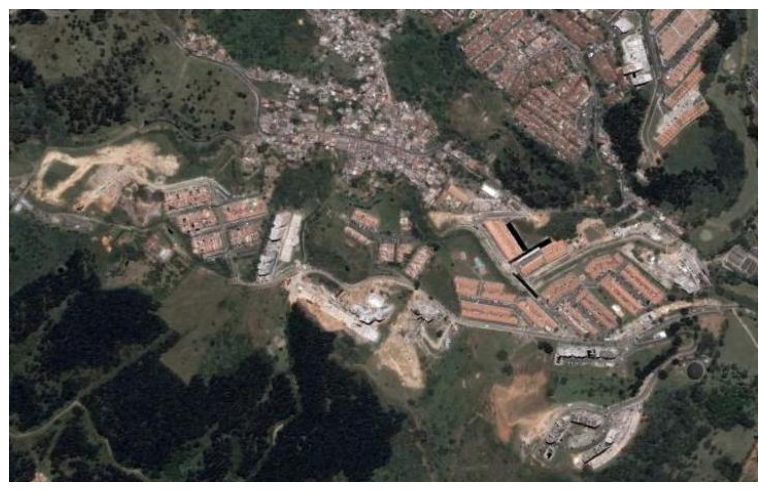

Fuente: Google Earth. Consulta: febrero 2 de 2012

Foto 65. Morfologías irregulares y cerradas como propuestas de expansión. Suroccidente

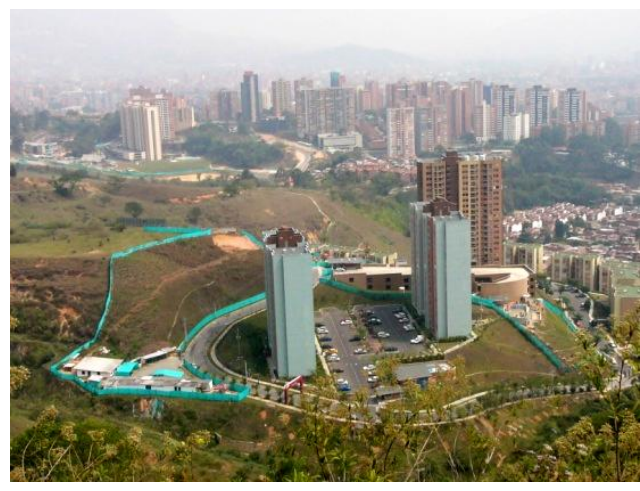

Fuente: César Salazar, 2010. 
Foto 66. Procesos de expansión al centro occidente de Medellín, 2004

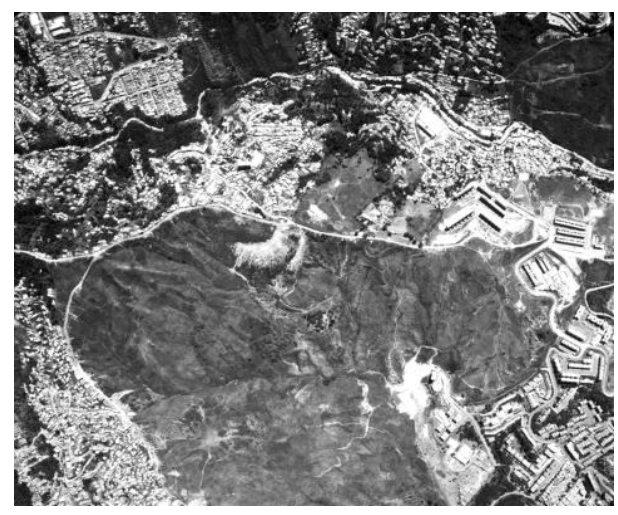

Fuente: Catastro Medellín.

Foto 68. Proceso de expansión urbana en el barrio Alto de Calasanz, centro occidente

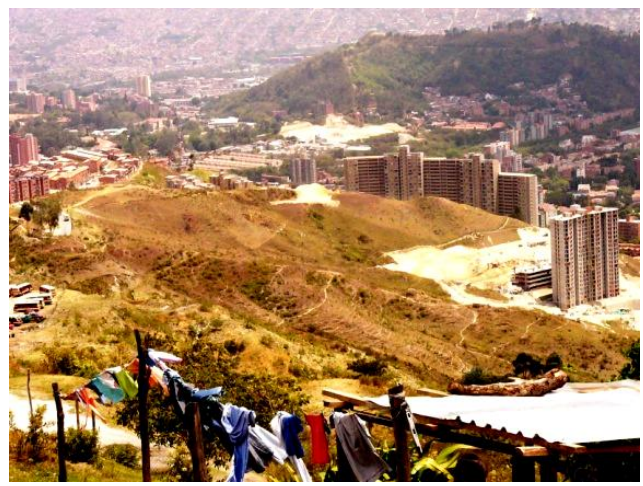

Fuente: César Salazar, 2010.
Foto 67. Procesos de expansión al centro occidente de Medellín, 2007

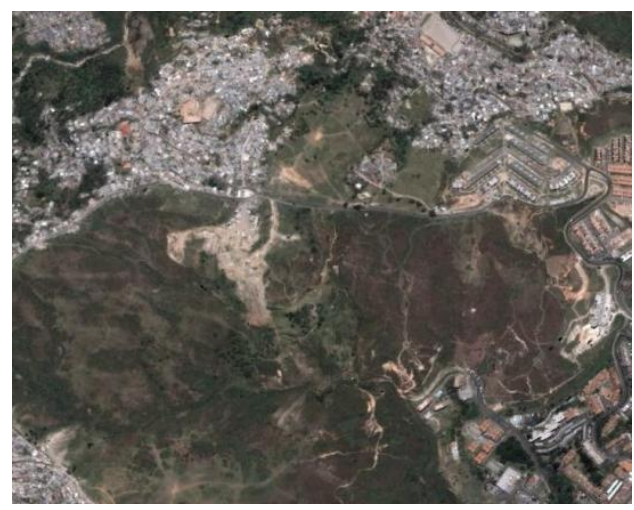

Fuente: Google Earth. Consulta: febrero 2 de 2012

Foto 69. Proceso de expansión urbana en el sector Pajarito, centro occidente

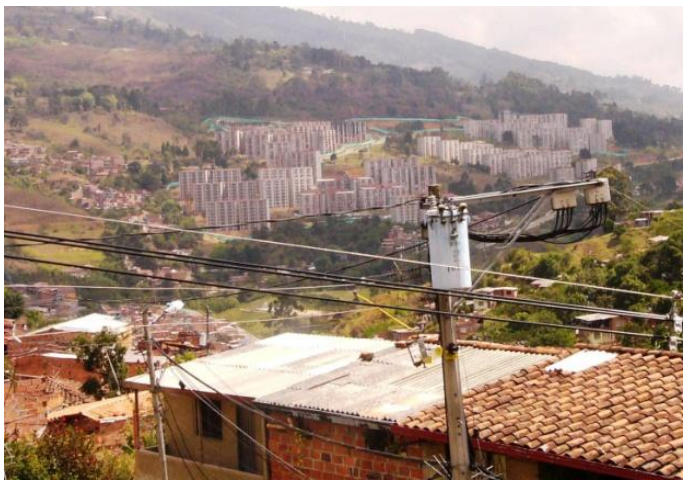

Fuente: César Salazar, 2010.

\subsubsection{Borde urbano plegado absorbente}

Este tipo de superficies aparece en los bordes urbanos que configuran polígonos especializados de uso industrial y servicios complementarios al mismo, en sus áreas aledañas se desarrollaron zonas residenciales, gestionadas especialmente en las décadas del cincuenta al setenta del siglo XX, previas a la entrega de la producción de vivienda al sector financiero. En la actualidad, varios de estos sectores son apetecidos por el mercado inmobiliario, que frente a la escala y consolidación del uso predominante, introduce un componente que detone un proceso de transformación, tanto en el imaginario colectivo como en los valores del suelo.

La estrategia de este tipo de plegamiento sobre la superficie urbana intenta generar una dinámica interna y aislada en el sector específico, en donde se inserta el componente detonante de la transformación. El componente introducido se comporta como un vórtice que atrae a actores urbanos provenientes de distintos sectores de la ciudad, con los que recrea nuevos imaginarios que comienzan, 
en un proceso de colonización, a dominar una porción del territorio mucho más amplia que la que ocupa el componente invasivo.

El impacto que genera la introducción del nuevo componente, así como la incesante publicidad que lo rodea, afecta la toponimia de los lugares, y determina en gran medida el proceso de configuración histórica de los barrios. Y los nombres de los lugares cambian a medida que más componentes se introducen al sitio recolonizado, y mientras otros componentes que lo configuraban inician un proceso de destierro, o como se aprecia en otros casos, permanecen pero cambiando su significación para ser aceptado dentro del proyecto de reterritorialización.

En el recorrido efectuado entre los estratos narrativos del paisaje fue posible identificar varios bordes de este tipo en algunas de las áreas industriales que fueron definidas por la planificación de la ciudad desde mediados del siglo XX, o que incluso ya habían sido caracterizados por este uso en los albores de la industrialización de la ciudad. La industria en obsolescencia ya no está, aunque aún se mantienen algunos de sus rasgos morfológicos, pero lo que aún permanece son las estructuras residenciales que en un momento albergaban a los obreros y sus familias, y en la actualidad sostienen el hábitat de los sectores de clase media y baja, muchas de las cuales derivan su sustento económico en el mismo lugar. 
Ilustración 29. Incorporación de centros comerciales en áreas industriales en obsolescencia, cercanas a áreas residenciales consolidadas

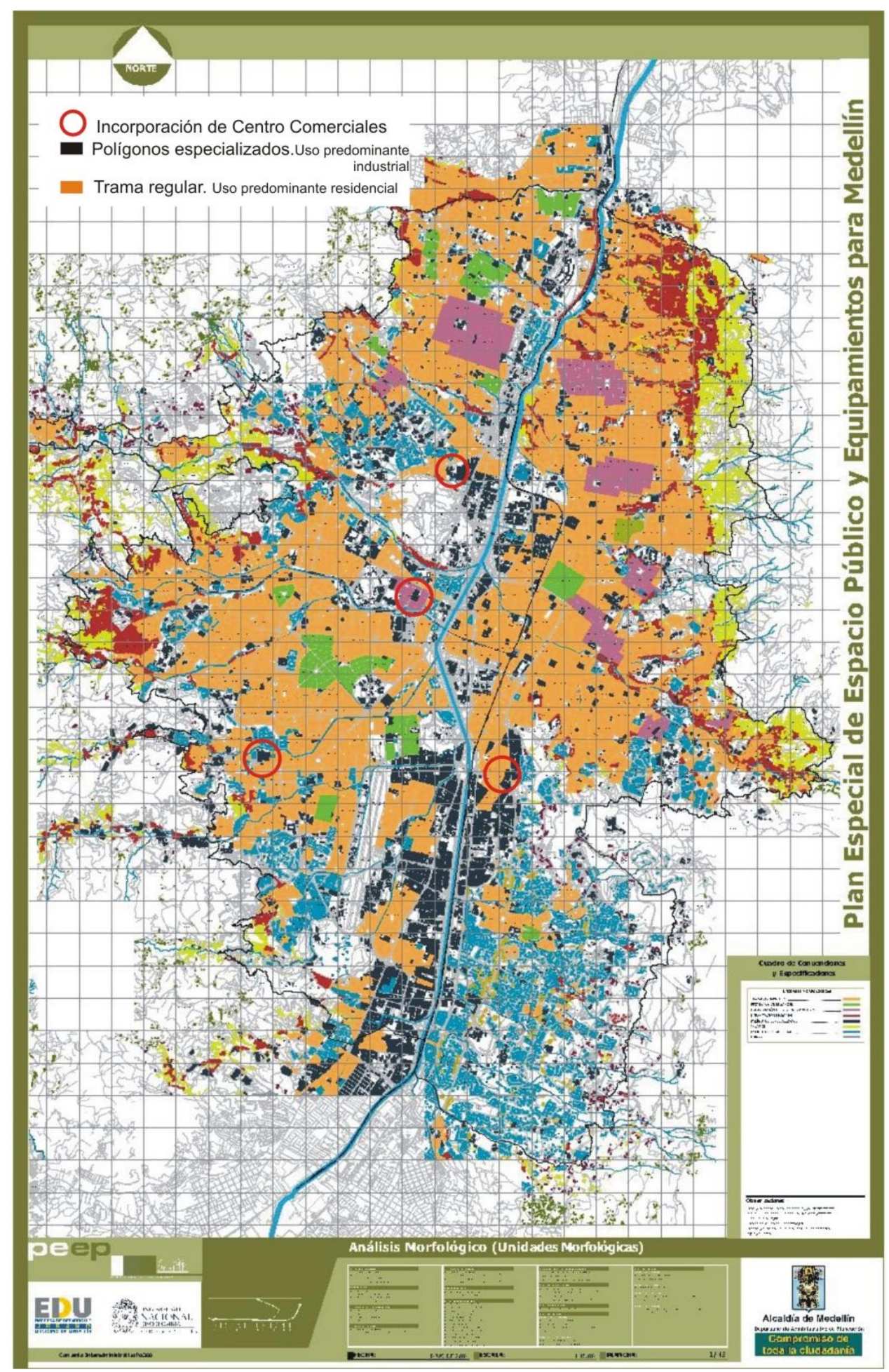

Fuente: Municipio de Medellín (2006). "Plan Especial de Espacio Público y Equipamientos”, Medellín. 
Ilustración 30. Valor de las transacciones inmobiliarias previas a la localización de centros comerciales, 2005

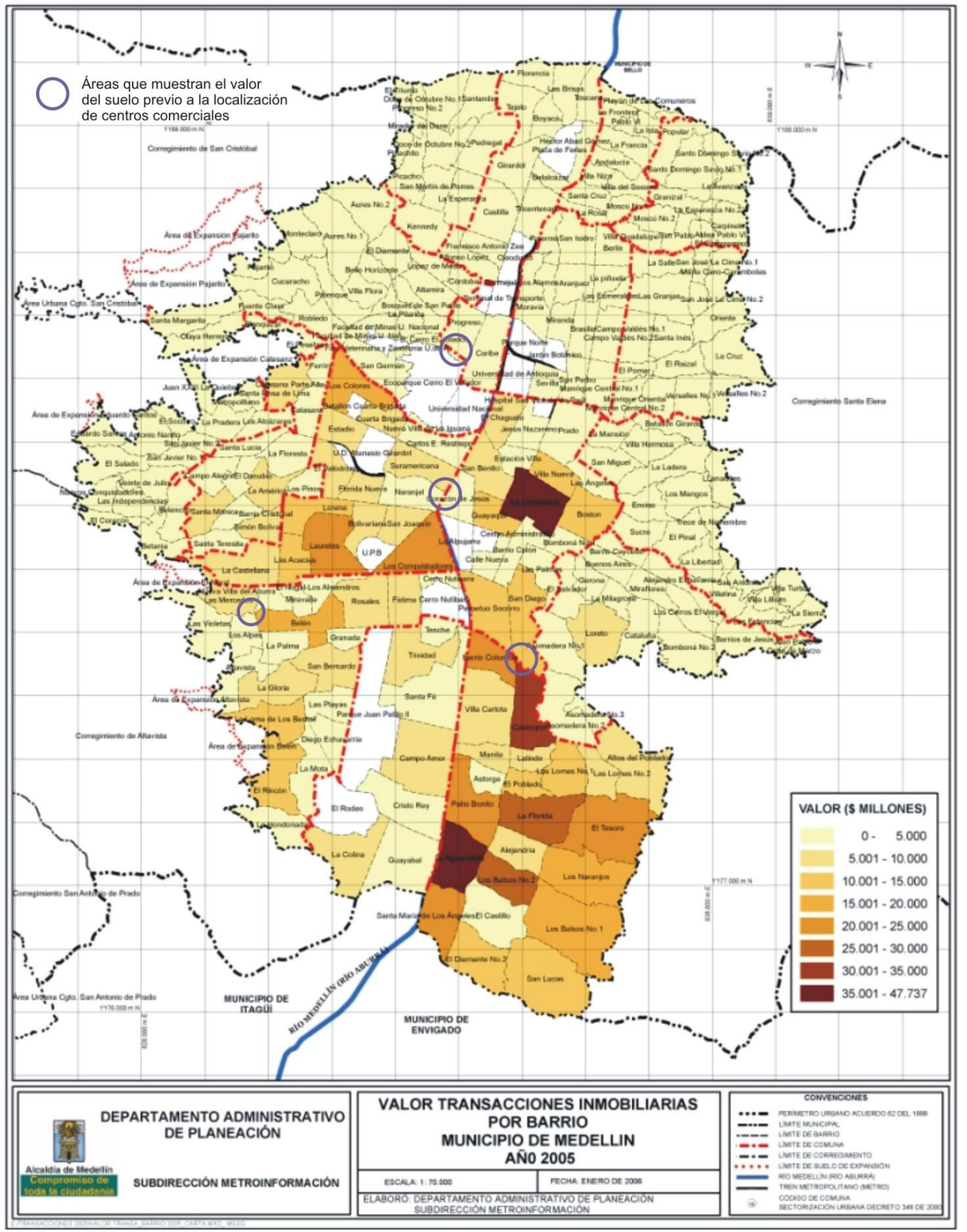

Fuente: DAPM (2005). “Observatorio del Suelo y del Mercado Inmobiliario”, Medellín. 
Ilustración 31. Valor de las transacciones inmobiliarias después de la construcción de los centros comerciales, 2007

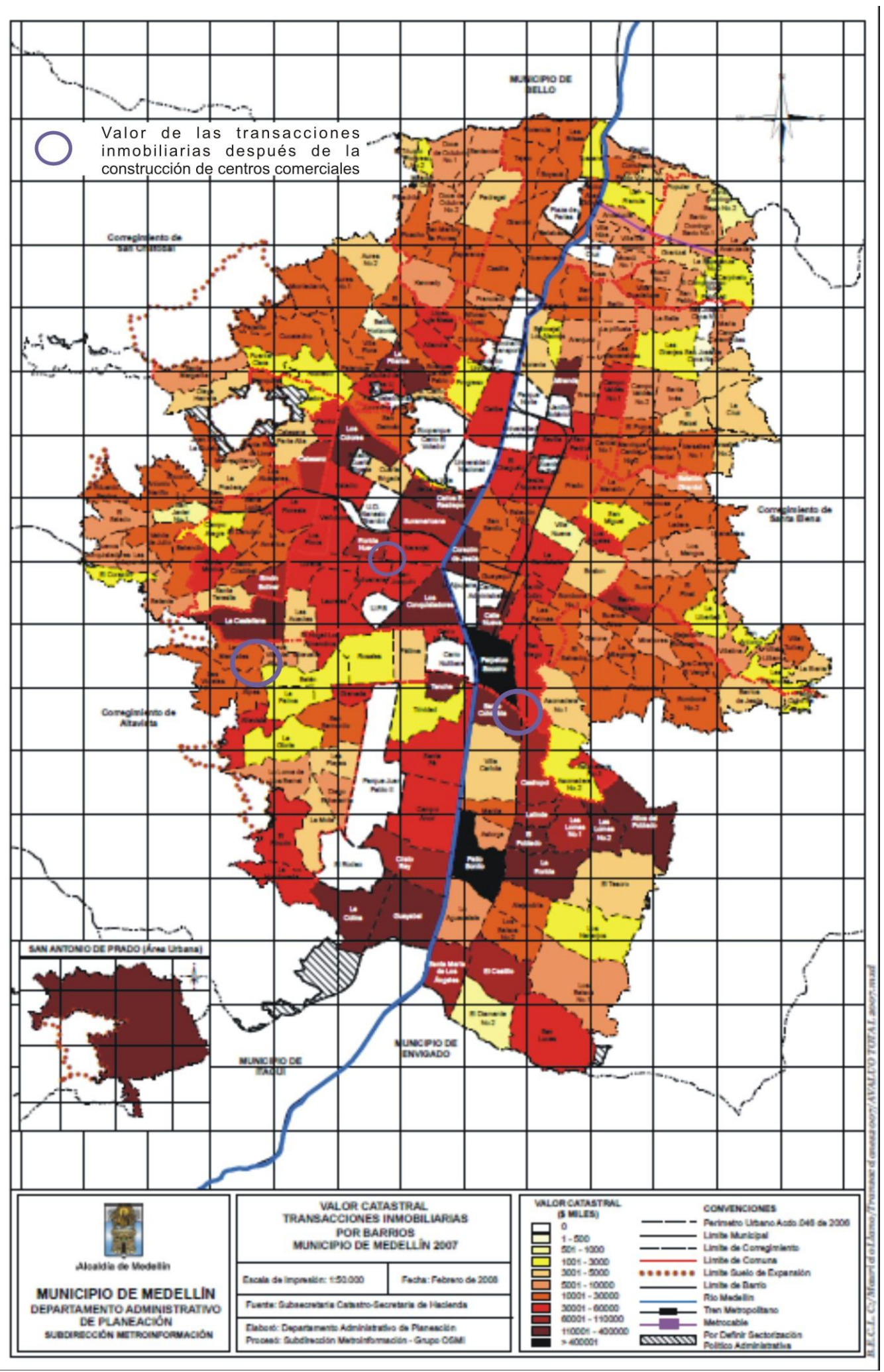

Fuente: DAPM (2007). “Observatorio del Suelo y del Mercado Inmobiliario”, Medellín. 
Foto 70. Sector industrial al centro occidente en estado de obsolescencia, 2004

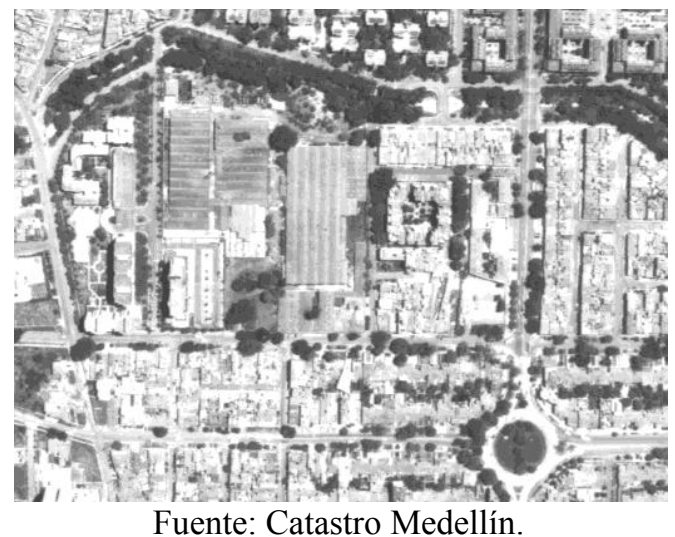

Foto 72. Centro comercial Los Molinos. Centro occidente de la ciudad

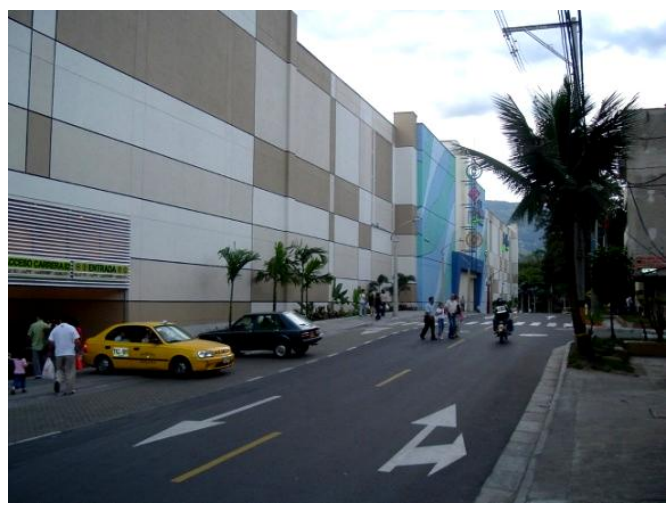

Fuente: Panoramio, disponible en:

www.panoramio.com. Consulta: febrero 10 de 2012

Foto 74. Zona industrial de Medellín cercana al centro tradicional, 2004

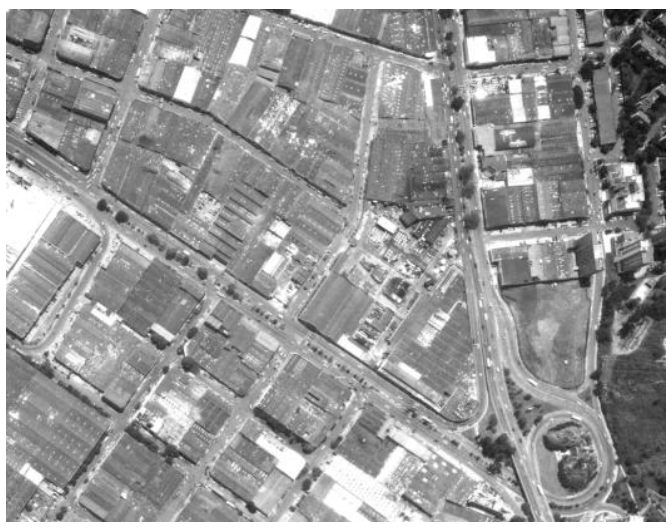

Fuente: Catastro Medellín.
Foto 71. Centro comercial al centro occidente en lugar de industria que abandona, 2007

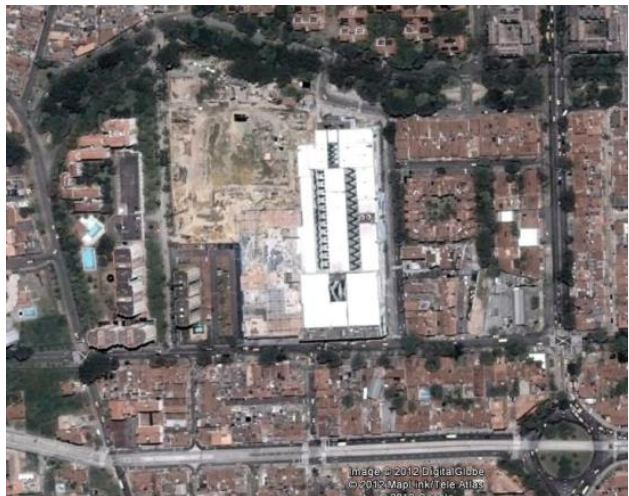

Fuente: Google Earth. Consulta: febrero 4 de 2012.

Foto 73. Centro comercial Premium Plaza. Cercano al centro tradicional

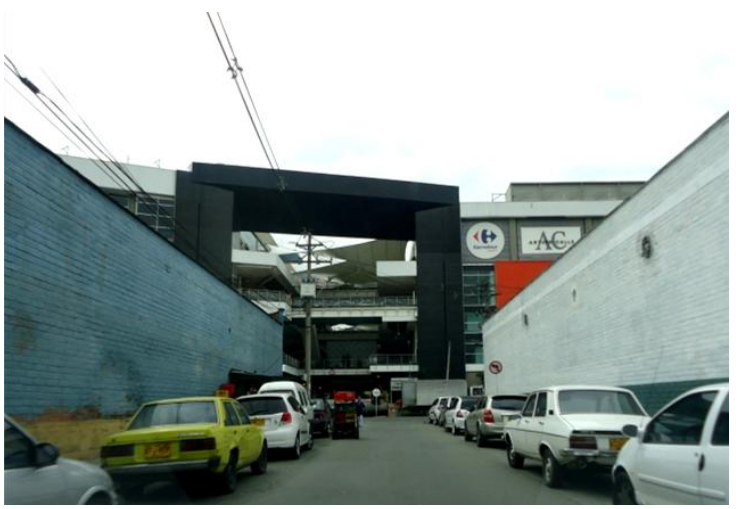

Fuente: César Salazar, 2012.

Foto 75. Transformación de zona industrial cercana al centro tradicional, 2007

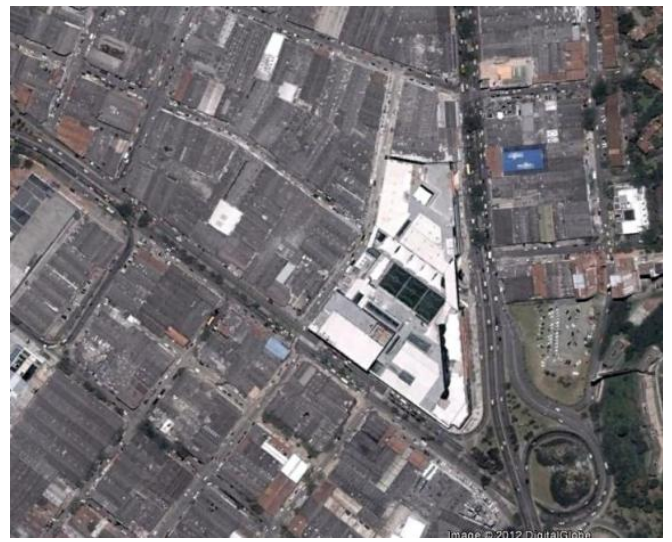

Fuente: Google Earth. Consulta: febrero 2 de 2012 


\subsection{Bordes urbanos sedimentados}

Corresponden a estructuras de carácter más inestables, producto de procesos de transformación en marcha, que al abrirse camino sobre el escenario urbano dejan al descubierto componentes que quedan en situaciones fluctuantes. Este de tipo bordes recrea varias tendencias en las que se destacan procesos de descodificación en los elementos que permanecen, adquiriendo nuevos y distintos significados, o convirtiéndose en contenedores y receptores de procesos de reanimación territorial (reterritorialización), al proveer o favorecer el desarrollo para el poblamiento de componentes nuevos y atávicos signos territoriales.

Estos bordes son singulares al estar expuestos a fuerzas de transformación externas, que al incorporar elementos diferenciales a la composición espacio-temporal modifican no sólo las trayectorias de los actores urbanos tradicionales, sino que también introducen otros actores en capacidad ventajosa de crecimiento y propagación. Esto genera un nuevo estado de degradación, y debilitamiento de los factores que configuraban los relatos sobre el estrato narrativo precedente del paisaje urbano y modifica los ejes de sentido por las acciones de amontonamiento, separación o disgregación que emergen en el espacio y en el tiempo.

\subsubsection{Borde urbano sedimentado amontonado}

Superficies urbanas que se derivan de impactantes operaciones de transformación del paisaje, especialmente en la zona núcleo de la ciudad. Varios de los elementos que fueron obligados a desplazarse (desterritorializados) de la zona núcleo, encuentran, como lugar de reasentamiento, áreas circunvecinas que se han consolidado como áreas de abrigo para los exiliados urbanos.

Estas áreas se comportan como rincones de la ciudad a donde van a parar los componentes que han sido desechados, en el proceso de selección, por los discursos que se imponen en la narrativa del paisaje y que ostentan mayor representatividad. Su localización en la ciudad los convierte en lugares o áreas aprisionadas, ya que se configuran en sectores muy delimitados por los movimientos que ejercen los estratos que los circundan. Éstos en sus procesos de transformación y cambio, arrojan todo aquel componente que no se acomode a los nuevos ejes de sentido sobre las áreas del exilio, amontonándose así cualquier variedad de elementos sin un aparente orden narrativo.

En el recorrido realizado entre los estratos narrativos de 1890, 1910 y 1925, confrontados con la experiencia actual, se hallaron dos sectores que se han venido configurando con el predominio de este tipo de borde urbano. Uno de estos se encuentra delimitado entre los ejes de mayor nivel de actuación en la zona núcleo y las áreas periféricas de estos estratos narrativos, tanto al occidente y al sur (río Aburrá y la restaurada estación de ferrocarriles de Antioquia). El otro corresponde a las áreas aledañas al sitio que desde la colonia se marcó como el lugar de los muertos (antiguo cementerio San Lorenzo, convertido en la actualidad en un parque) y sitio para la caridad católica con los mendigos y los ancianos pobres. 
En el primer sector se han venido replegando las agitadas actividades que rodeaban la Plaza Cisneros (escenario de congregación social, económica y política en la primera mitad del siglo XX), la Plaza de Mercado Cubierta y la estación del ferrocarril. En el sector reconocido como Guayaquil, al interior de los ejes y corredores urbanos que han sido objeto de re-habilitación, se han concentrado los inquilinatos, burdeles, las tabernas y cafés, en los que aún se escucha el tango, y toda actividad comercial que sostiene el intercambio de una masa en incesante movimiento por las calles.

Foto 76. Sector de Guayaquil

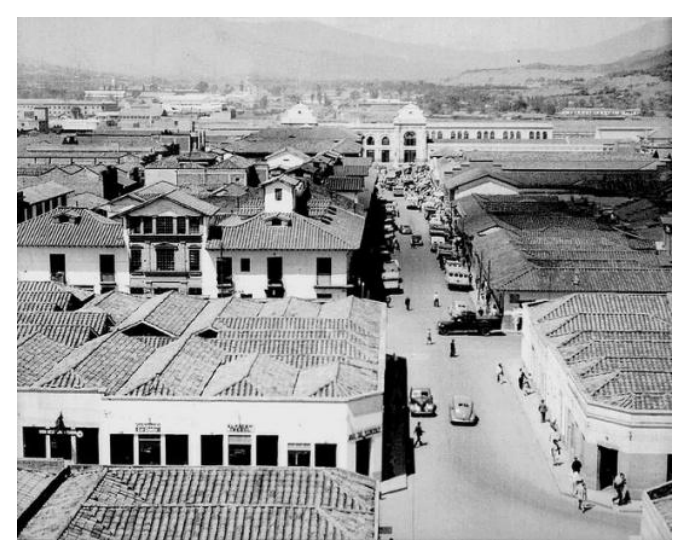

Fuente: Rodríguez, ca.1950.

Ilustración 32. Imagen intervenida del sector de Guayaquil

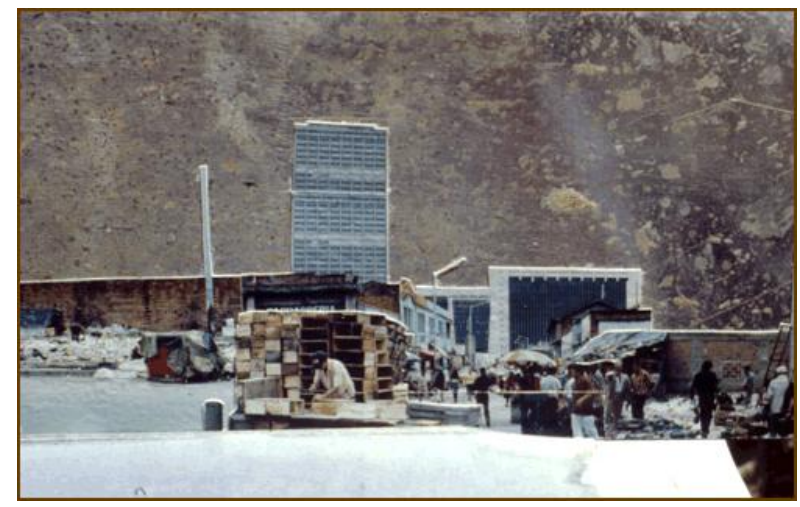

Fuente: Fundación Viztaz (s.f.). Un siglo de vida en Medellín. Versión digital. Medellín (anónimo).
Foto 77. Ventas en la calle. Guayaquil

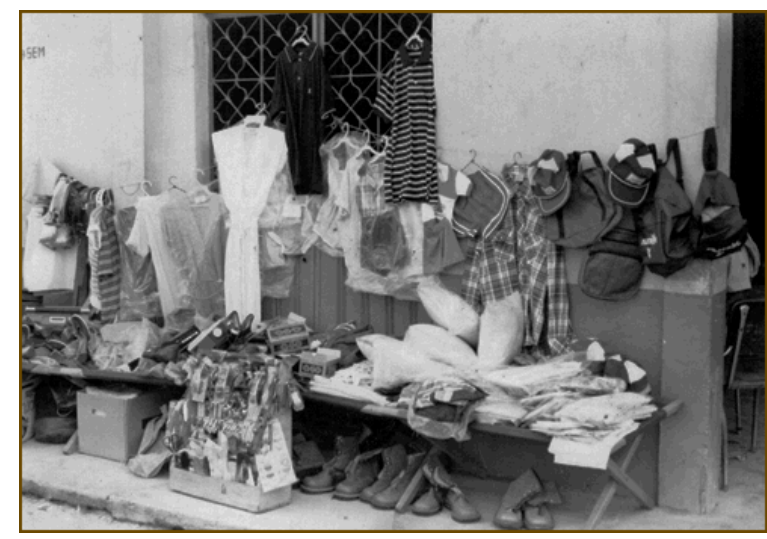

Fuente: Fundación Viztaz (s.f.). Un siglo de vida en Medellín. Versión digital. Medellín (anónimo).

Foto 78. Desde la Plaza de Cisneros mirando al interior de Guayaquil a principios de los $80 \mathrm{~s}$

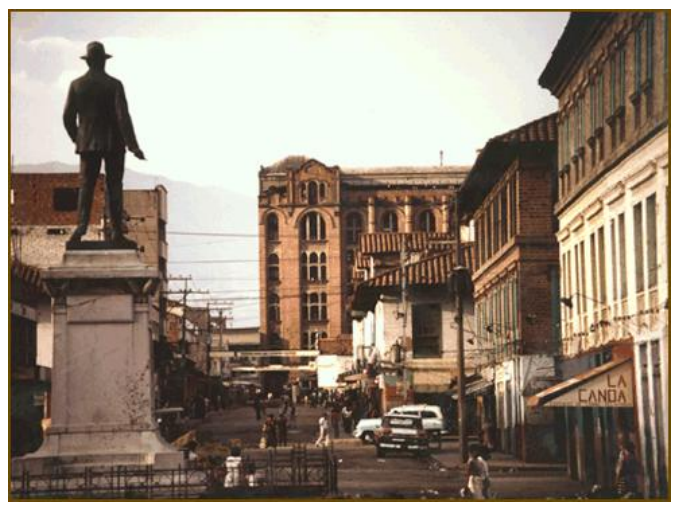

Fuente: Fundación Viztaz (s.f.). Un siglo de vida enMedellín. Versión digital. Medellín (anónimo). 
Foto 79. Monumento al ingeniero Cisneros también en el exilio. Interior de estación de ferrocarril restaurada

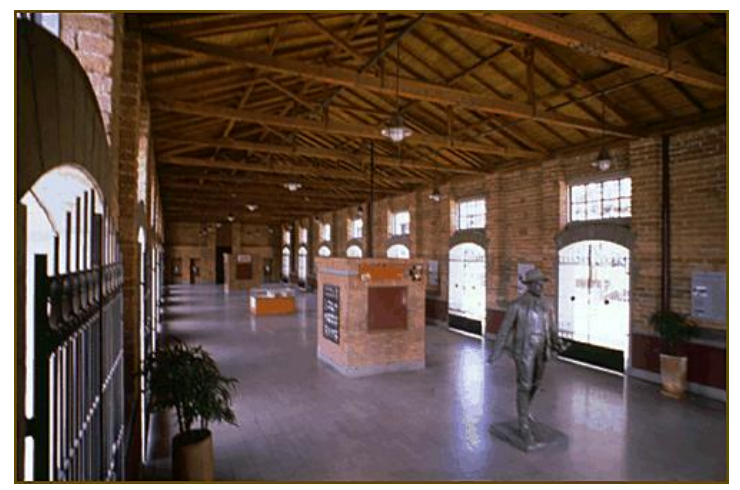

Fuente: Fundación Viztaz (s.f.). Un siglo de vida en Medellín. Versión digital. Medellín (anónimo).
Foto 80. Entorno actual de la Plaza de la Luz, antigua Plaza Cisneros

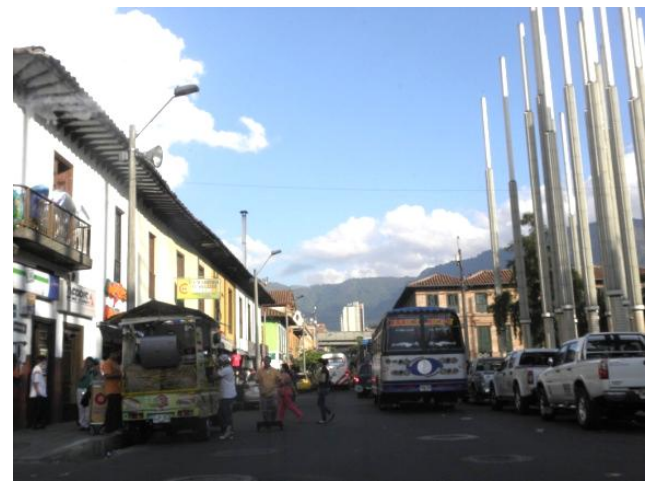

Fuente: César Salazar, 2012.

\subsubsection{Borde urbano sedimentado desperdigado}

Superficies urbanas que muestran la separación de componentes que integraban un mismo itinerario o relato paisajístico, es alterado por la incursión o reforzamiento de nuevos ejes que pretenden conectar centralidades, que conforman el proyecto de representación del poder. Este tipo de borde se configura en una ruptura de la superficie discursiva por fuerzas externas al mismo, que no sólo introducen nuevos componentes, sino que también, de manera no intencionada, realzan los componentes que se encuentran en los sustratos, abriendo heridas que parecían cerradas sobre el espacio y el tiempo.

Este tipo de bordes muestra que todo intento de plegamiento sobre el espacio urbano, procurando delinear nuevos esquemas imaginativos (organización autoritaria, Delgado, 2010), terminan exacerbando la estructura de las mismas superficies, objeto de operación, originando aperturas por las que comienzan a resurgir esas complejas texturas urbanas que siempre escapan a cualquier proyecto de estandarización cultural.

En el recorrido efectuado para confrontar las dinámicas que se dan sobre los primeros estratos narrativos del paisaje urbano de Medellín (1890, 1910 y 1925), se evidencian varios sectores en donde predomina este tipo de borde urbano. Uno de estos corresponde al eje natural sobre el cual se estructuró el primer estrato narrativo del paisaje, la quebrada Santa Elena, que a partir de mediados del siglo XX fue cubierta para convertirla en uno de los corredores de movilidad en sentido orienteoccidente. El segundo tiene relación directa con uno de los nuevos ejes de movilidad que propuso el Plan Piloto de Medellín y materializado en la década del setenta, irrumpiendo de sur a norte el tejido del núcleo central, denominado avenida oriental.

El primer caso tiene lugar en el tramo de la quebrada Santa Elena que no fue objeto de cobertura, y cuyas márgenes fueron colonizadas por morfologías de carácter informal para dar cabida en gran parte a los primeros arrabales de la ciudad a finales del siglo XIX, así como residencia a algunas de las 
familias de los proletarios de la empresa de tejido que se localizó en este sitio a principios del siglo XX. Este sitio se configuró en el borde de dos ciudades, la formal y la informal. Dicha fábrica, Coltejer, abandonó el sector hace ya más de una década, siendo reemplazada por un conjunto habitacional, acelerando desde entonces el proceso de transformación.

Ahora sobre este tramo se inicia la construcción de un parque lineal, bajo el pretexto de conmemorar el Bicentenario de la Independencia y el comienzo de la era Republicana. La generación de este eje ambiental, como lo denominan, pretende recrear un corredor ceremonial entre el núcleo tradicional de la ciudad y los barrios periféricos del centro occidente, caracterizados por la diversidad cultural, pues no hay que olvidar que gran parte de ellos han sido construidos por inmigrantes de distintos lugares del mundo rural colombiano.

Estas intervenciones urbanísticas, como lo expresa Delgado (2010):

Repiten unos mismos esquemas formales estandarizados, de manera que la imagen singular de los barrios, hasta hace poco claramente diferenciados, tiende a recular a favor de una homogeneización estética cada vez más descarada paralela a aquella otra que se produce a nivel orgánico y funcional

Foto 81. Coltejer (Colombiana de Tejidos S.A) localizada en el sector de La Toma

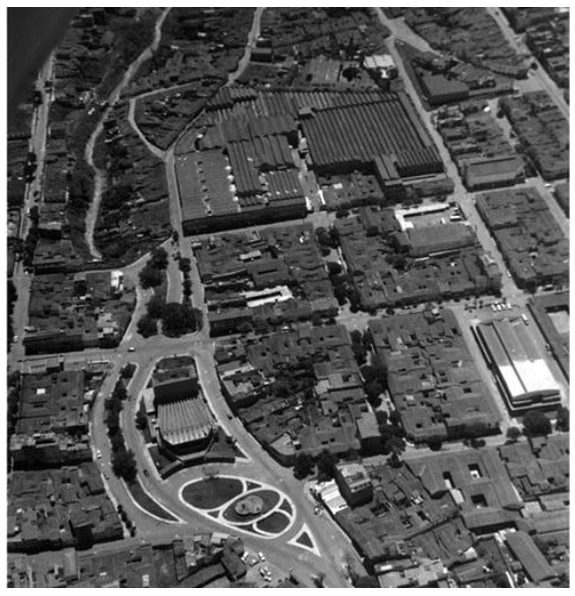

Fuente: Carvajal, ca. 1956.
Foto 82. Sectores residenciales que rodean a Coltejer

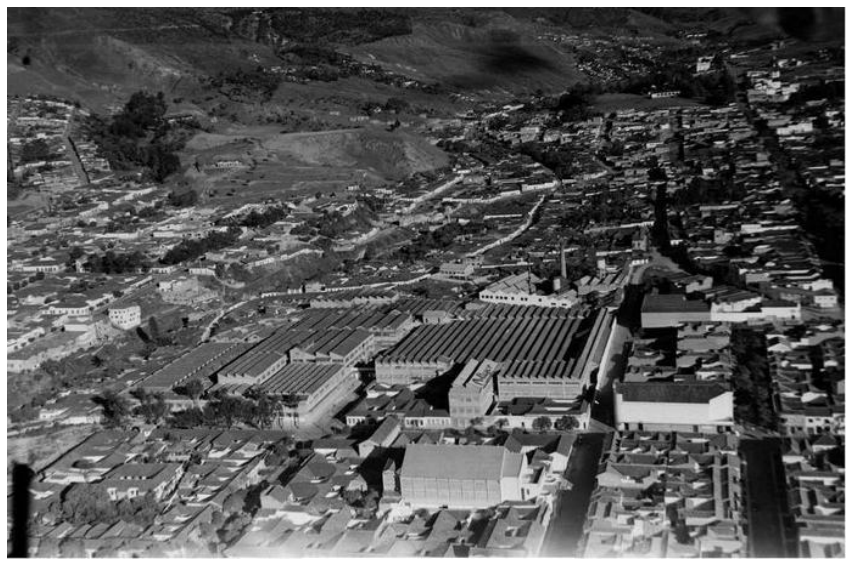

Fuente: Carvajal, ca. 1956. 
Foto 83. Los techos y chimeneas de Coltejer

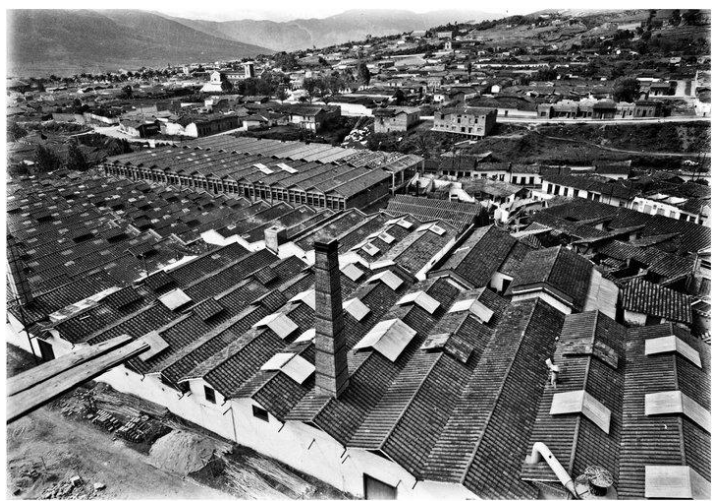

Fuente: Francisco Mejía, ca. 1937.

Foto 85 . Viviendas cercanas a la fábrica de Coltejer

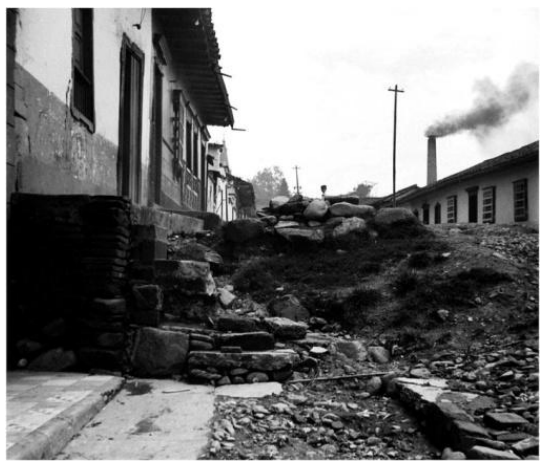

Fuente: Carvajal, ca. 1944.

Foto 87. Demoliciones para la construcción del Parque Bicentenario

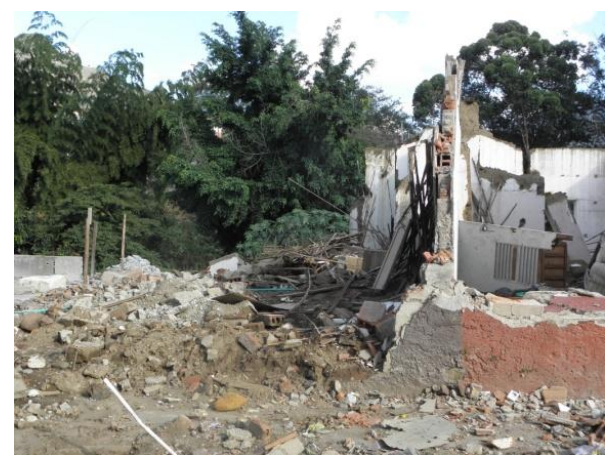

Fuente: César Salazar, 2012.
Foto 84. Fachadas y chimeneas de Coltejer

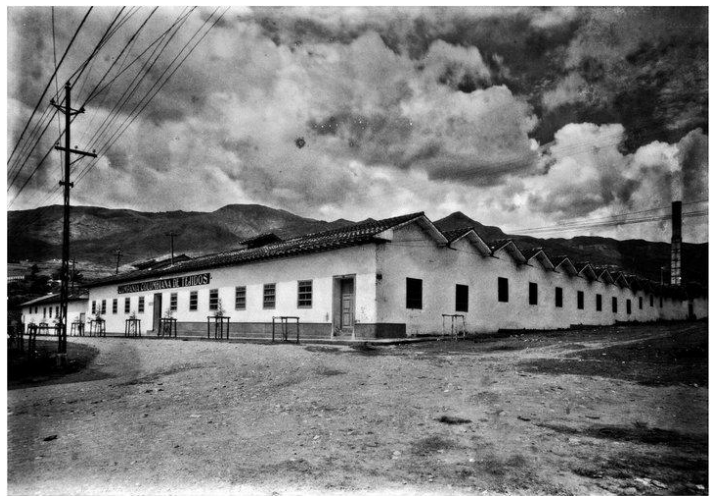

Fuente: Francisco Mejía, ca. 1937.

Foto 86. Sector de La Toma. Barrio del centro- occidente de Medellín

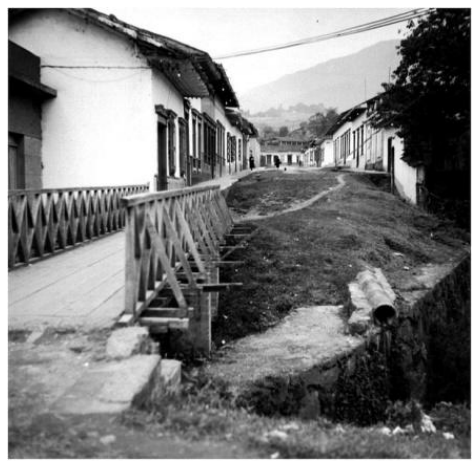

Fuente: Carvajal, ca. 1944.

Foto 88. Construcción de puente sobre la quebrada Santa Elena (Parque Bicentenario) para dar continuidad a la circunvalar

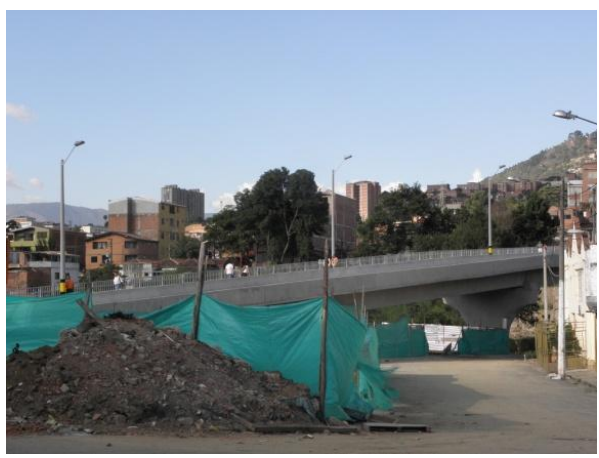

Fuente: César Salazar, 2012. 
Foto 89. Transformación sobre las márgenes de la quebrada Santa Elena. Parque Bicentenario

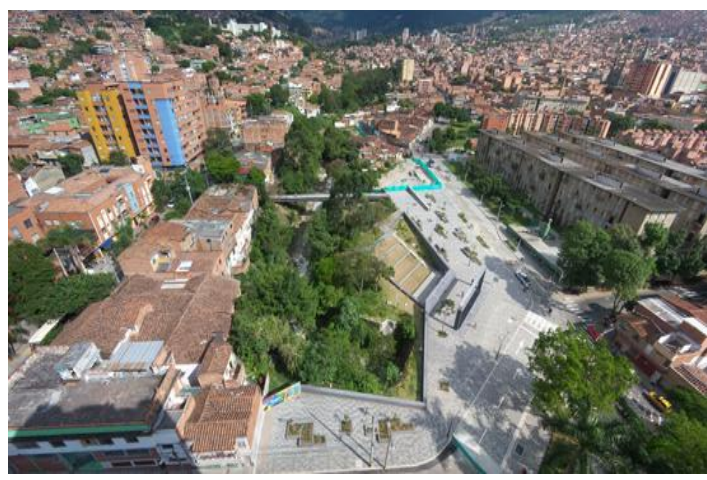

Fuente: Municipio de Medellin, disponible en http://www.medellin.gov.co/irj/portal/medellin

Foto 90. Pantalla de agua. Parque Bicentenario

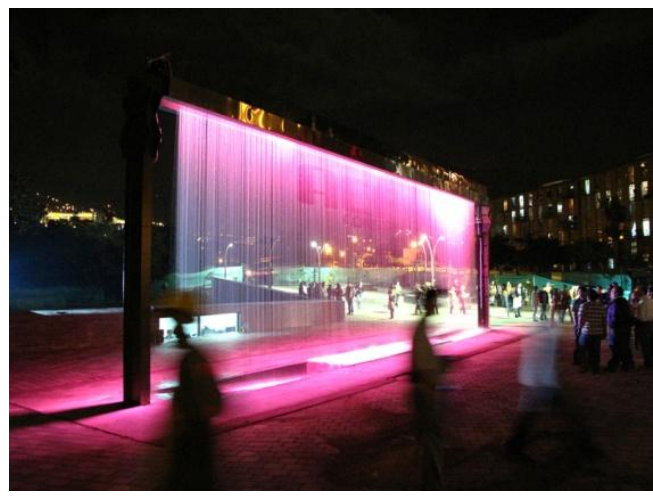

Fuente: DesignFun, disponible en: www.designfun.net. Consulta: enero 15 de 2012
Ilustración 33.Planta urbana del Parque Bicentenario

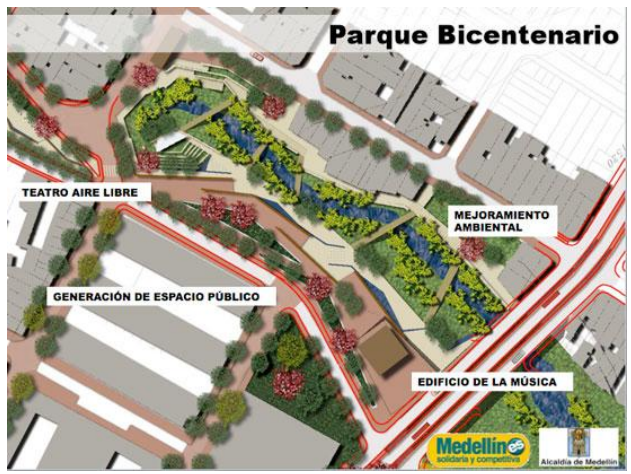

Fuente: Municipio de Medellin, disponible en: http://www.medellin.gov.co/irj/portal/medellin

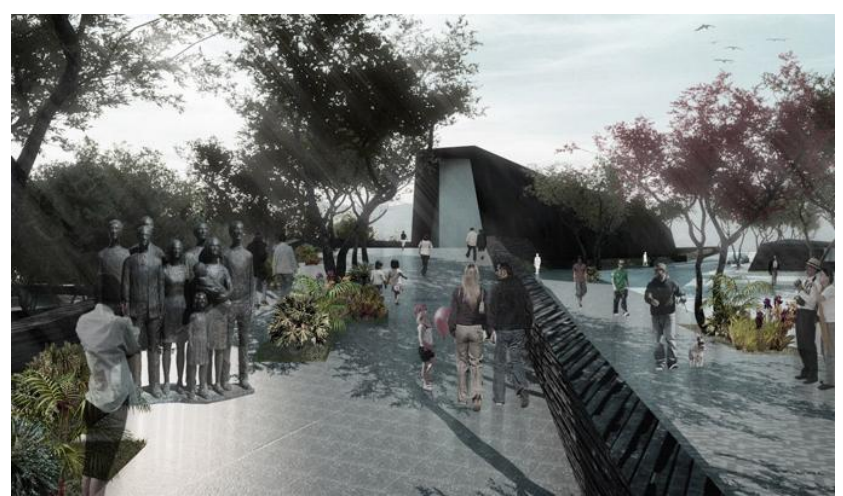

Fuente: DesignFun, disponible en: www.designfun.net. Consulta: enero 15 de 2012

\subsubsection{Borde urbano sedimentado desagregado}

Superficies urbanas que surgen de políticas para la delimitación de actividades que han quedado en situación de exilio urbano, con la pretensión de re-ordenarlas de tal manera que sus modos de desarrollo se efectúen con restricciones. En este tipo de borde prevalece la presencia de los marginados y los desclasados que deambulan por un escenario intencionadamente acotado, con la firme intención de evitar su propagación por la zona núcleo de la ciudad, lugar de la representación de las imágenes del poder.

En el borde urbano sedimentado desagregado emergen elementos que garantizan un control del comportamiento, por esta misma razón su ordenamiento en el espacio es sensible a estrategias de aislamiento de otros factores que puedan ocasionar una agitación descontrolada. Aún así, en este tipo 
de bordes se aprecia cómo los distintos tipos de usos, de actividades y actores urbanos entretejen diversas texturas en las que es difícil a veces distinguir los objetos, o más bien, definirlos por categorías cerradas.

Las pretensiones de una política de confinamiento de usos, actividades, rutinas y actores no gratos para el proyecto de una identidad central, terminan por favorecer la construcción de nuevas alianzas urbanas, entre actores aparentemente disímiles. Tales situaciones configuran nuevos relatos y trayectorias, apelando entre varias estrategias al reciclaje urbano y a la re-semantización de los componentes dispuestos para la generación de paisajes; de re-composiciones a partir de la desagregación de elementos que conformaban otro tipo de sistemas o relatos paisajísticos.

En el recorrido realizado entre los bordes urbanos que resultan entre las placas narrativas de 1890-1910 y 1925, confrontadas con la experiencia contemporánea, este tipo de borde sedimentado fue identificado en la periferia noroccidental del núcleo de la ciudad. Recordemos cómo en el recuento narrativo del paisaje urbano de Medellín, la aparición del ferrocarril en la década de 1910 habilita un corredor de suelo urbano, paralelo a la franja del río, acondicionado a su vez por las operaciones de canalización del cauce de este eje que estructuró especialmente la localización de la actividad industrial.

Hacia 1984 se relocaliza la Plaza de Mercado Cubierta sobre este corredor, en el cruce entre la quebrada Santa Elena, ya cubierta para dar lugar a la avenida Primero de Mayo, con la Avenida Ferrocarril, antiguo eje ferroviario ahora constituido como una de las principales arterias viales de la ciudad. Como se destacó en el apartado del borde de plegamiento conglomerado, esta acción se deriva por la reconfiguración del nuevo centro cívico metropolitano, proyecto que apreciaba como intrusos a la Plaza de Mercado Cubierta y todo el sector de comercio que la rodeaba.

Estas escenas, obscenas para las operaciones de purificación urbana, exigieron el desplazamiento de la Plaza de Mercado Cubierta y el desarraigo de todos aquellos que operaban a su alrededor, que en su conjunto habían configurado un ecosistema urbano de complejísimas relaciones de interdependencia, promovidas por la costumbre del mercado de víveres vendidos a bajos precios, y al que acudían personas provenientes directamente de las zonas rurales de la región y del país. La nueva localización de la plaza de mercado, por su confinamiento, provoca la colonización de algunos corredores urbanos, donde las actividades complementarias que la persiguen, como inquilinatos, bodegas, centros de acopio de material reciclado, almacenes de baratijas, entre otros usos, algunos considerados oprobiosos, se relocalizan ahora de manera desagregada, pero ampliando el área de influencia territorial. 
Foto 91. Periferia del núcleo de Medellín. Avenida Primero de Mayo (quebrada Santa Elena) - Río Medellín, 1959

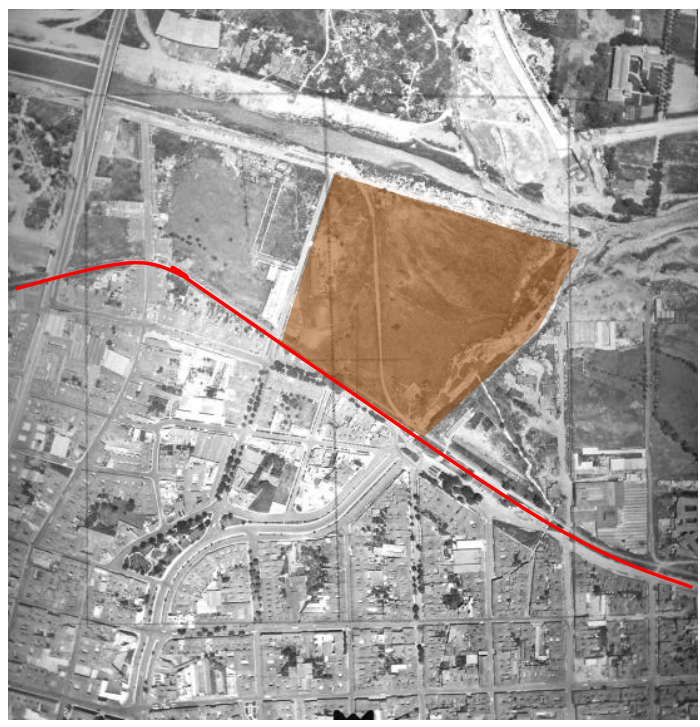

Fuente: Catastro Municipio de Medellín.
Foto 92. Periferia del núcleo de Medellín. Avenida Primero de Mayo (quebrada Santa Elena) - Río Medellín, 1975

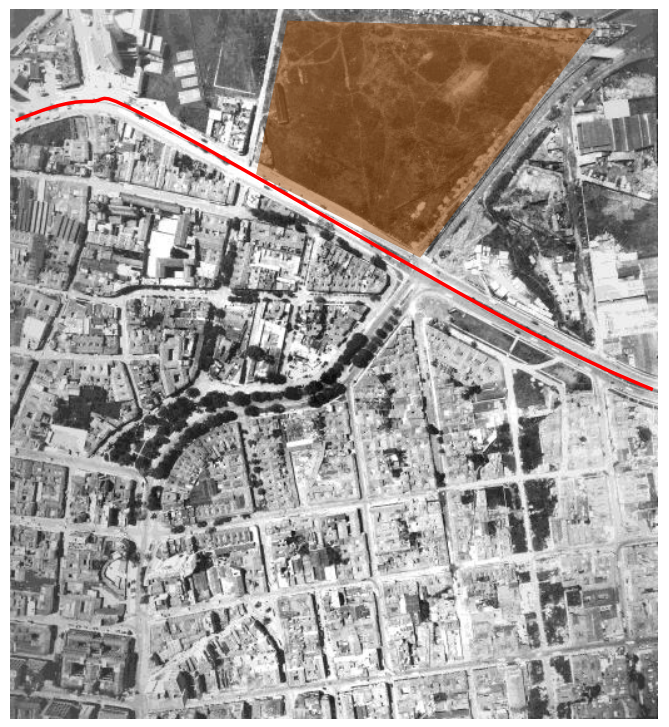

Fuente: Catastro Municipio de Medellín.

Foto 93. Periferia del núcleo de Medellín. Avenida Primero de Mayo (quebrada Santa Elena) - Río Medellín, 1994. Localización de la plaza de mercado cubierta (Minorista)

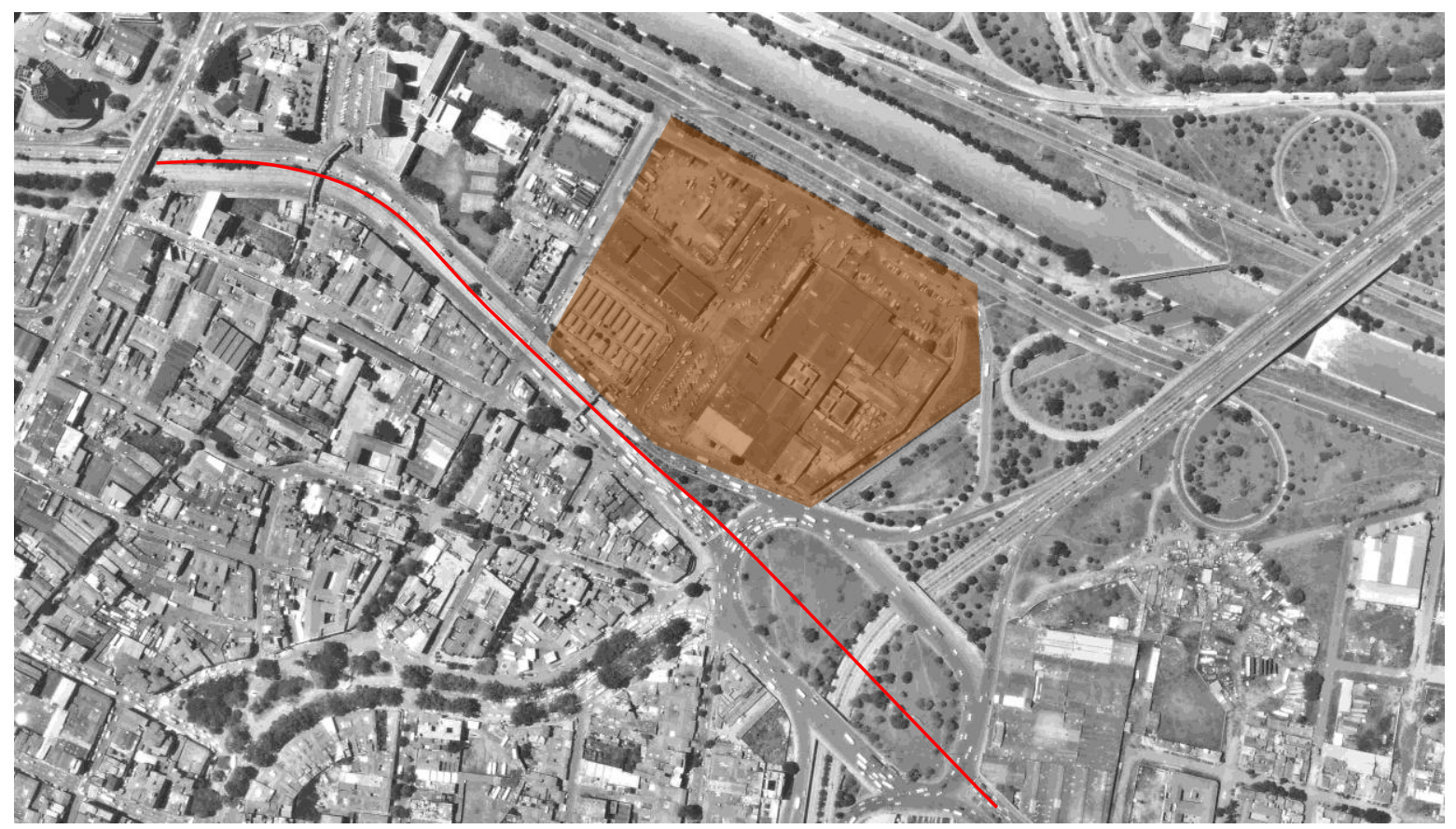

Fuente: Catastro Municipio de Medellín. 
Foto 94. Antigua Estación Villa del sistema ferroviario

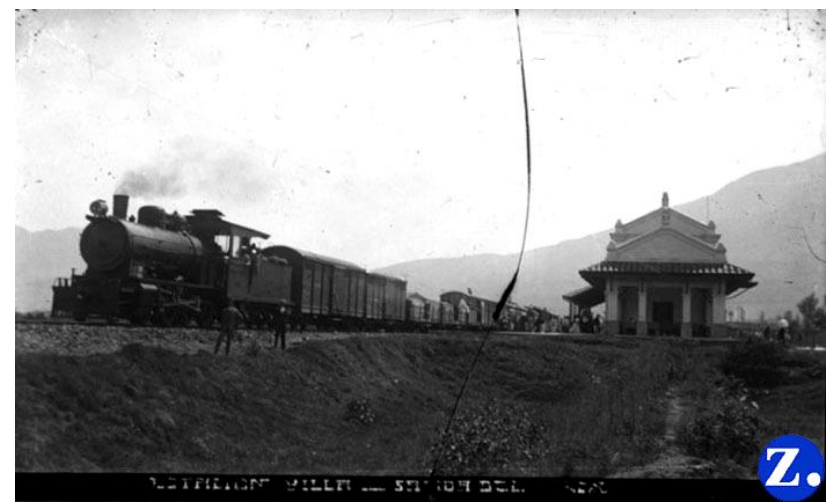

Fuente: Memoria fotográfica de Medellín, disponible en: http://www.viztaz.com.co/unsiglo/bancodigital/ciudad.htm

Foto 96. Comercio informal alrededor de la Plaza Minorista

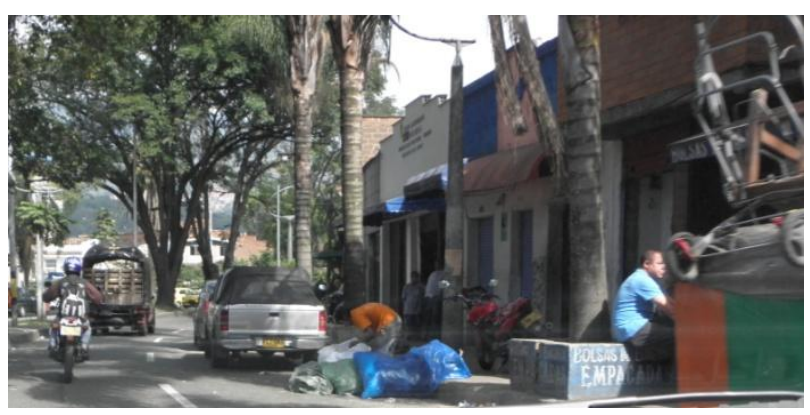

Fuente: César Salazar, 2012.

Foto 98. Movimientos alrededor de la Plaza Minorista

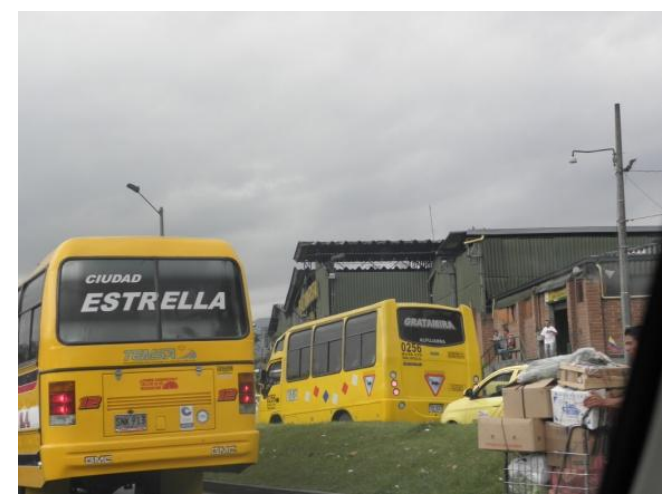

Fuente: César Salazar, 2012.
Foto 95. La Plaza de Mercado Cubierta o Plaza Minorista

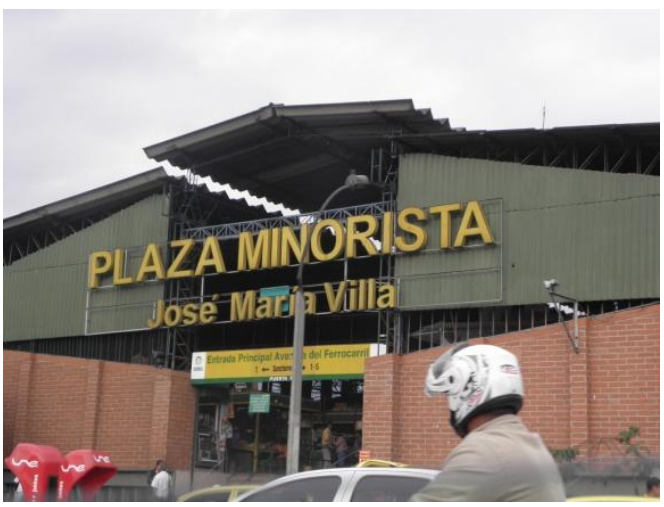

Fuente: César Salazar, 2012.

Foto 97. Almacén de baratijas, calle La Paz, cerca a la Plaza Minorista

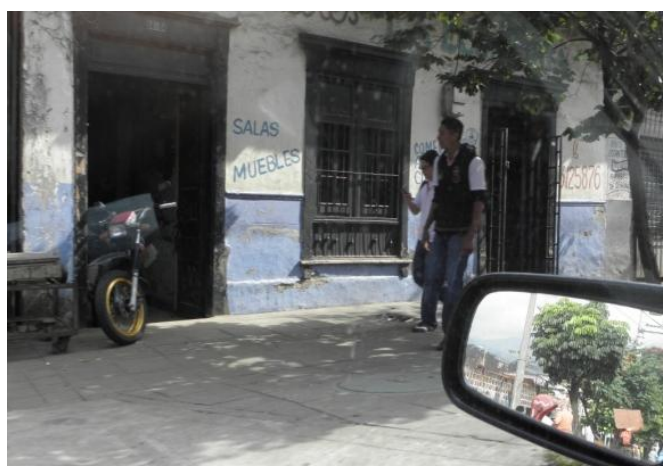

Fuente: César Salazar, 2012.

Foto 99. Movimientos bruscos de exiliados urbanos atravesando vías rápidas

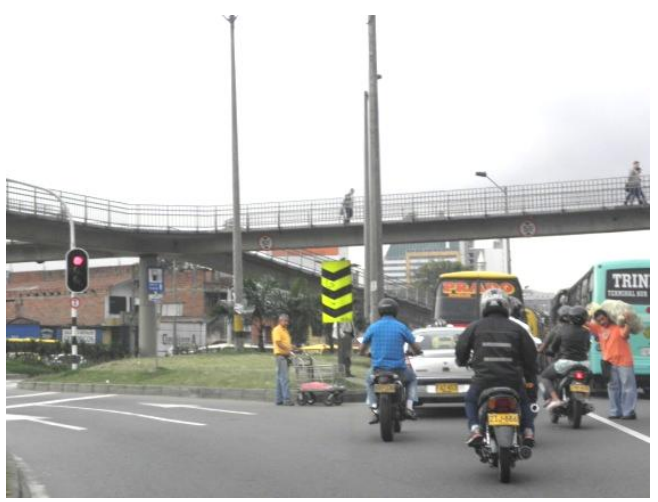

Fuente: César Salazar, 2012. 


\subsubsection{Borde urbano sedimentado saturado}

Superficies urbanas producto de operaciones sobre el espacio urbano en el que se insiste en la abrupta introducción de componentes que por su escala y proporción terminan por saturar y congestionar el paisaje. Esta situación se presenta porque las nuevas tipologías edilicias aparecen en disonancia con las características morfológicas del lugar, desconociendo el proceso de adaptación que se requiere para que los nuevos componentes estructuren un texto narrativo coherente. A su vez, este tipo de borde muestra cómo los componentes introducidos alteran las rutinas de los actores urbanos locales, ya que algunos signos que configuran su memoria inician procesos de desterritorialización.

Foto 100. Proceso de expansión en el centro-oriente de la ciudad, 2004

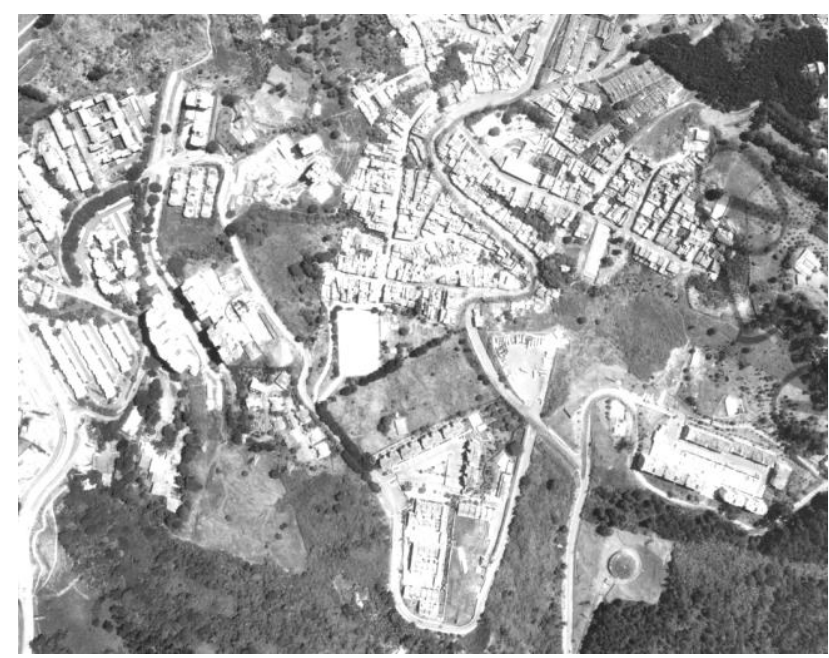

Fuente: Catastro Medellín.

Foto 102. Proceso de redensificación en el barrio Belén Rincón, suroccidente (1)

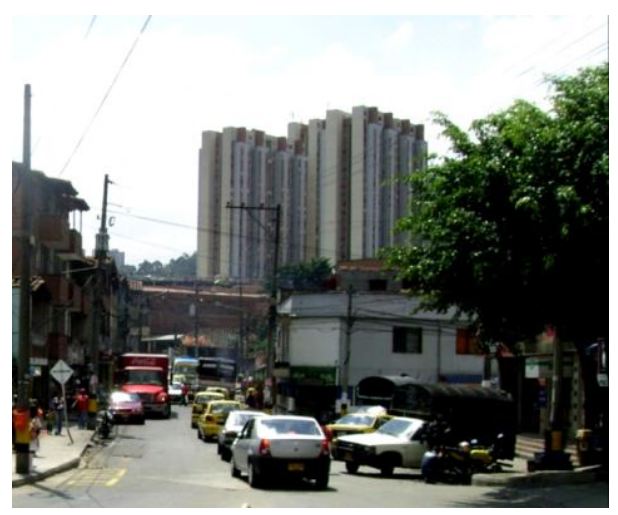

Fuente: César Salazar, 2010.
Foto 101. Proceso de expansión en el centro- oriente de la ciudad, 2008

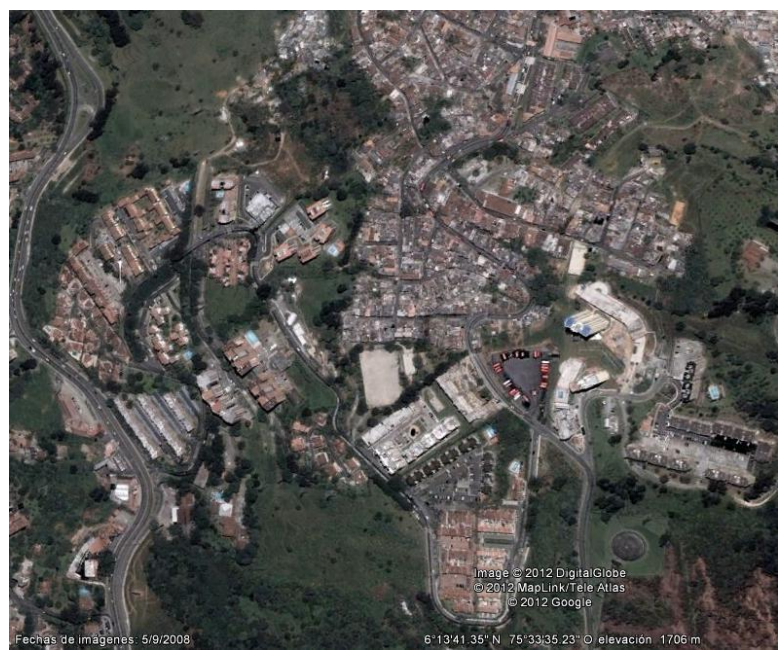

Fuente: Google Earth. .Consulta: febrero 6 de 2012

Foto 103. Proceso de redensificación en el barrio Belén Rincón, suroccidente (2)

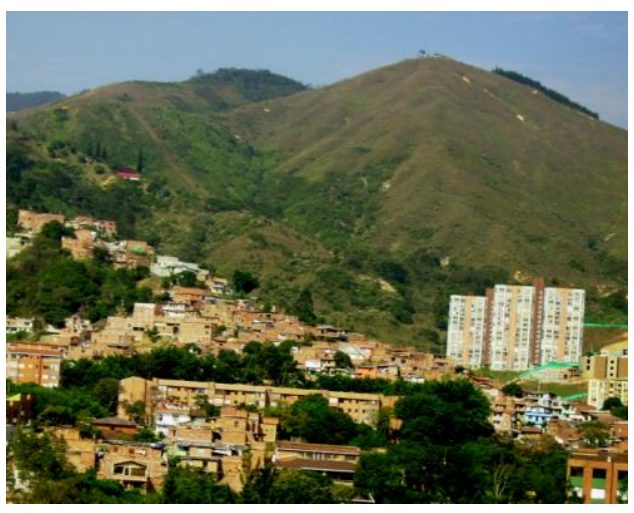

Fuente: César Salazar, 2010. 
Este tipo de bordes evidencian la desconfiguración de la forma urbana, que tiene sentido en la organización de los objetos sobre el espacio, para así marcar las pautas del tiempo que con significación oportuna siguen los actores locales. Debido a estas operaciones de alto impacto, la memoria se convierte en letargo, pues los itinerarios que recreaba el paisaje urbano, están ahora disociados en la nueva sintaxis propuesta por la introducción abrupta de componentes que persiguen la colonización del espacio, a través del destierro de componentes que constituían la estructura narrativa del paisaje.

El borde urbano sedimentado saturado es fruto de un urbanismo anamórfico, en el cual la disposición de los componentes semióticos ya no reproduce los actos que dan sentido a las trayectorias que siguen los actores urbanos. Al contrario, producen escenas de confusión, ya que la amnesia predomina en los ahora autistas urbanos que repelen cualquier contacto con los otros, percibidos con sospecha o ignorados por completo. En este tipo de borde, las imágenes muestran agitadas escenas de personas que se cruzan, sin embargo, lo que se aprecia es una danza incesante de autómatas urbanos.

\subsection{Incidencia de la forma de los tipos de borde urbano en la calidad del paisaje}

Hoy hay más gente, más edificios, más diversiones, mayores comunicaciones y una capacidad técnica que permite hacer realidad todas las extravagancias, sin embargo el hombre no se identifica con su entorno e incluso se ha desentendido de hacer valoraciones sobre la realidad formal que para él se ha construido (Gordon Cullen citado por Pablo Arias, 2003)

Revisando lo afirmado por diversos autores podría decirse que coinciden que paisaje es el resultado de experiencias portadoras de una huella colectiva organizada como memoria técnica, social y figurativa del lugar. La memoria habita el espacio en la acepción del tiempo y también en la perspectiva de un horizonte espacial que incita el cambio, el movimiento y la duración.

Es en estos términos que reconocemos el paisaje como una organización tecnológica de la memoria colectiva e individual, siempre presta a la mutación, la ruptura y la creación de formas, estilos y composiciones asociadas a conductas, deseos y proyectos de vida.

Cuando la memoria asocia lo real y lo irreal, la experiencia y la ficción, la estabilidad y el movimiento, los lugares y sus componentes físicos desarrollan tensiones cuyo desenvolvimiento y fin propician argumentos y contenidos para actualizar la poética de la ocupación y la construcción del espacio habitado.

Este apartado pretende señalar las cualidades que caracterizan los distintos tipos de borde urbano, identificados en esta investigación a partir de unas nuevas categorías estéticas del paisaje urbano. Lo que se intenta a continuación es develar las estructuras de memoria funcionales y formales, que condicionan la experiencia perceptiva de los ciudadanos que atraviesan constantemente estas diferentes escenografías urbanas. 
A través del establecimiento de tres tipos de indicadores, los primeros asociados a la presión que ejerce el espacio construido sobre el suelo: índice de compacidad, el segundo tipo asociado más a la diversidad presente en el espacio urbano: índice de complejidad, y el tercer tipo de índice o en este caso de análisis gráfico relacionado con los estudios de sintaxis espacial (space syntax): ${ }^{50}$ gráfico de axialidad (accesibilidad) urbana.

Es en algunos paisajes donde los ciudadanos reconocen ambientes caracterizados por la banalidad, o por el contrario, por la estridencia. ${ }^{51}$ Mientras otros ambientes permiten revitalizar la diversidad y facilitan a los ciudadanos ejercitar la rememoración, o si se prefiere recobrar los ejes de sentido en las trayectorias que delinean sobre el espacio urbano, gracias a que la distribución de los objetos en el espacio permite la lectura de los significados que estos guardan consigo, en la construcción de la historia y la cultura urbana.

\subsubsection{La compacidad urbana en los tipos de borde urbano}

La compacidad urbana es uno de los indicadores empleados para evaluar los modelos de sostenibilidad en las ciudades. A través de éste se aprecia el impacto de la densidad edificatoria, o si se prefiere, la relación en términos matemáticos entre el espacio construido y el espacio libre. El indicador de compacidad permite, en nuestro caso, constatar el nivel de ocupación del suelo y la distribución del área edificada dentro de los tipos de borde urbano identificados, y a su vez comprender los movimientos de sintetización, que en los procesos de transformación se producen dentro de éstos.

Con el cálculo y empleo de este indicador lo que se pretende verificar es la incidencia de la forma urbana en la calidad del paisaje urbano. Se trata de relacionar los valores que arroje la mapificación con los bordes plegados y sedimentados, y así, constatar los impactos que ocasionan los procesos de transformación, descritos en cada uno de estos tipos de borde urbano.

El medio construido (edificado) ejerce una presión sobre el territorio que requiere ser disipado o compensado por lugares de estancia que atenúan el impacto sobre el hábitat urbano. En este ejercicio se aprecia el comportamiento en tal sentido, de cada uno de los tipos de borde identificados. Los bordes urbanos que superan los niveles de compacidad absoluta, y corregida (Rueda, 2007), están asociados a niveles de percepción ininteligible (Olea, 1989). Mientras los que registren niveles por debajo del promedio se relacionan con ambientes caracterizados por la banalidad y una escasa dinámica de intercambio social, cultural y económico.

\footnotetext{
50 "Este método de análisis espacial tiene un hito fundamental en el trabajo teórico desarrollado en la década de los ochenta por Bill Hillier y una serie de alumnos con sede en The Bartlett, Londres. La sintaxis espacial surge como una vía para el estudio de los significados no verbales (o no discursivos) con posibilidades de aplicación para registrar la configuración espacial como elemento articulador de las relaciones sociales de los grupos humanos que las crean" (Bermejo,2009).

${ }^{51}$ Oscar Olea (1989) en su libro Catástrofes y monstruosidades urbanas hace referencia a los conceptos de ambientes banales e ininteligibles (estridentes, confusos).
} 
En los sectores que registren los niveles de compacidad sugeridos por los planteamientos de la sostenibilidad urbana (Rueda, 2007) sugieren que la relación espacio edificado y espacio libre mantiene una relación que facilita la orientación y la lectura de los ciudadanos en el entorno urbano. Esto exige monitorear muy de cerca los procesos de transformación que están en marcha en los bordes urbanos para que las condiciones que sostienen tales condiciones no se alteren, de tal forma que pierdan las proporciones adecuadamente obtenidas.

- Cálculo del índice de compacidad absoluta

Para efectuar el cálculo de este índice de compacidad urbana absoluta, se acude a las bases de datos del Plan de Ordenamiento Territorial de Medellín (Acuerdo 046 de 2006), específicamente en lo relacionado a la información predial (morfología urbana: llenos y vacíos), así como al registro de las alturas que cada uno de estos desarrolla sobre el espacio urbano. Obtenida esta información se procede de la siguiente manera:

1. Se sobrepone sobre el área urbana una malla conformada por cuadros de $200 \times 200$ metros (4 ha).

2. A través de herramientas SIG se procederá a hacer la suma del volumen de los edificios (resultado de multiplicar cada predio por su área y el número de pisos) en cada recuadro para ser dividido por el área de cálculo (4 ha).

3. Con los datos obtenidos por cuadrante se grafica el resultado en un mapa en el que se visualizarán las diferencias a través de 5 rangos.

Reconocidos ecólogos urbanos como Salvador Rueda sugieren que el nivel que garantiza mejor proporción y nivel de eficiencia en el cálculo de compacidad absoluta son los índices entre 5 y 7,5 metros. Sin embargo, la atención en la mapificación se centra en la aparición de las discontinuidades, que como surgimiento de formas sobre el espacio, sostienen superficies que en sus diversas configuraciones muestran diferentes estados evolutivos, en los cuales, la energía (la información) fluye en distintas direcciones, caracterizadas ya en unas nuevas categorías estéticas del paisaje urbano.

- Cálculo del índice de compacidad corregida

Aplicando el mismo procedimiento con la sobreposición de una malla de 200 x 200 sobre el área urbana de Medellín, se suman en cada recuadro el volumen edificatorio, pero esta vez el área a considerar para la operación y obtención del índice es la suma de los espacios de estancia, incluyendo únicamente: aceras de mínimo 5 metros de ancho, los parques, las plazas y áreas verdes acondicionadas para la apropiación efectiva. Para tal discriminación, se acude al mapa que clasifica los componentes del espacio público en el Plan de Ordenamiento Territorial de Medellín (Acuerdo 046 de 2006). 
El índice de compacidad corregida considera los espacios donde se efectúa la función atenuante o disipadora de la presión edificante ya que en estos se desarrolla el encuentro ciudadano. Se considera que para este tipo de compacidad los valores apropiados oscilan entre 10 y 50 .

- Cálculo del índice de compacidad ponderada

Para obtener este tipo de índice se procede de igual forma que en el caso de la compacidad corregida, sólo que esta vez los espacios de estancia se ponderan en relación a la influencia que ejercen en la compensación sobre el espacio construido (descompresión). En tal sentido, se emplea las mismas categorías del espacio público determinadas por el Plan de Ordenamiento Territorial de Medellín, esta vez diferenciadas por un factor que reconoce su potencial de descomprensión sobre el espacio construido.

Las categorías del espacio público en el Plan de Ordenamiento Territorial de Medellín son: parques, plazas, zonas verdes y zonas verdes viales. El factor diferenciador del potencial de descompresión son los siguientes, en el mismo orden en que se presentaron las categorías: 3, 2, 2 y 1. Estos factores multiplican las áreas que correspondan a estas categorías y que se hallan en los recuadros de 200 x 200 metros, resultado que divide el volumen edificado obtenido en los mismos recuadros de 4 hectáreas. 
Ilustración 35. Mapa de compacidad absoluta del área urbana de Medellín y su relación con los bordes urbanos

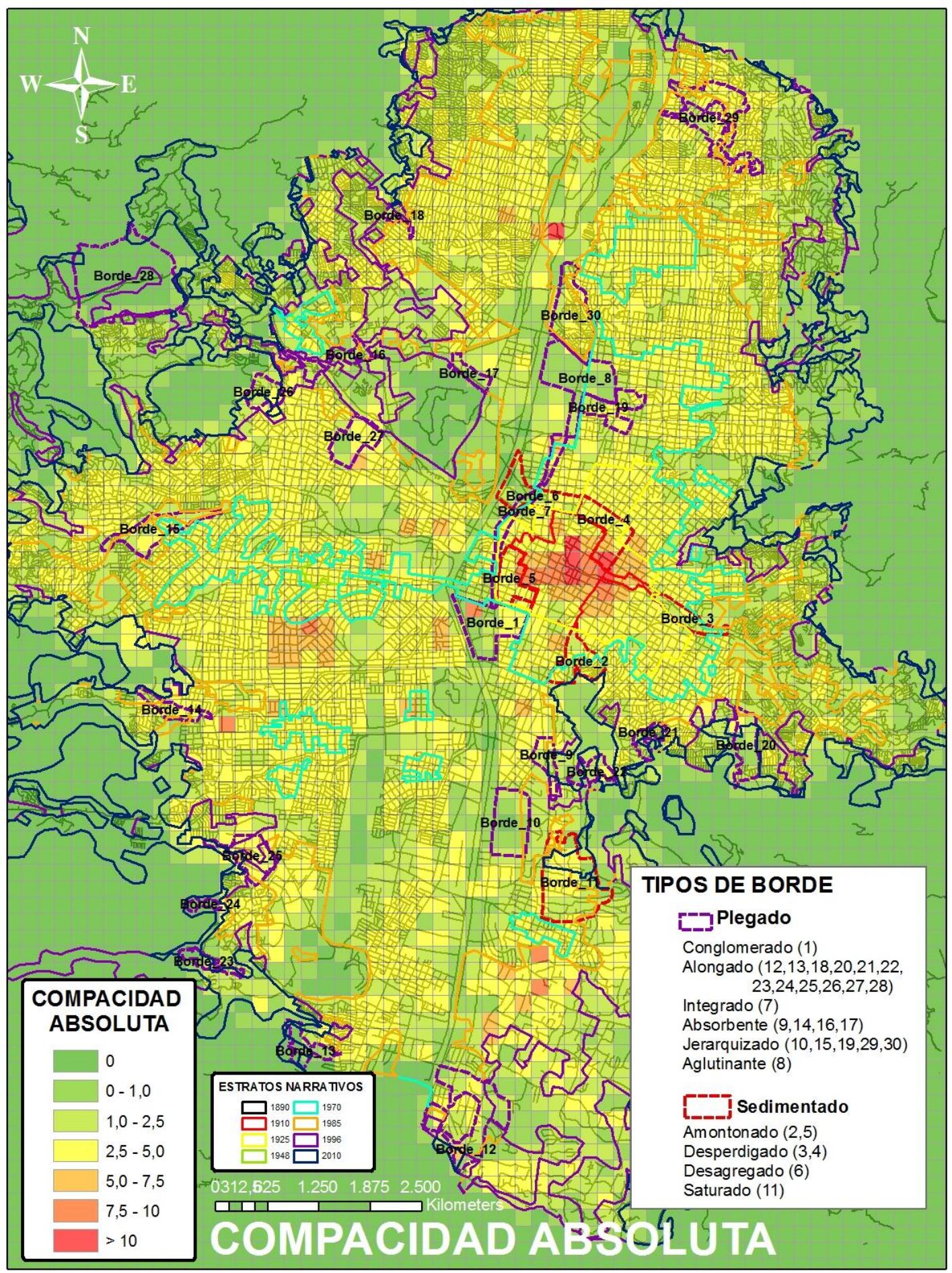

Fuente: ilustración elaborada por el autor con base en datos del POT de Medellín. 
Ilustración 36. Mapa de compacidad corregida del área urbana de Medellín y su relación con los bordes urbanos

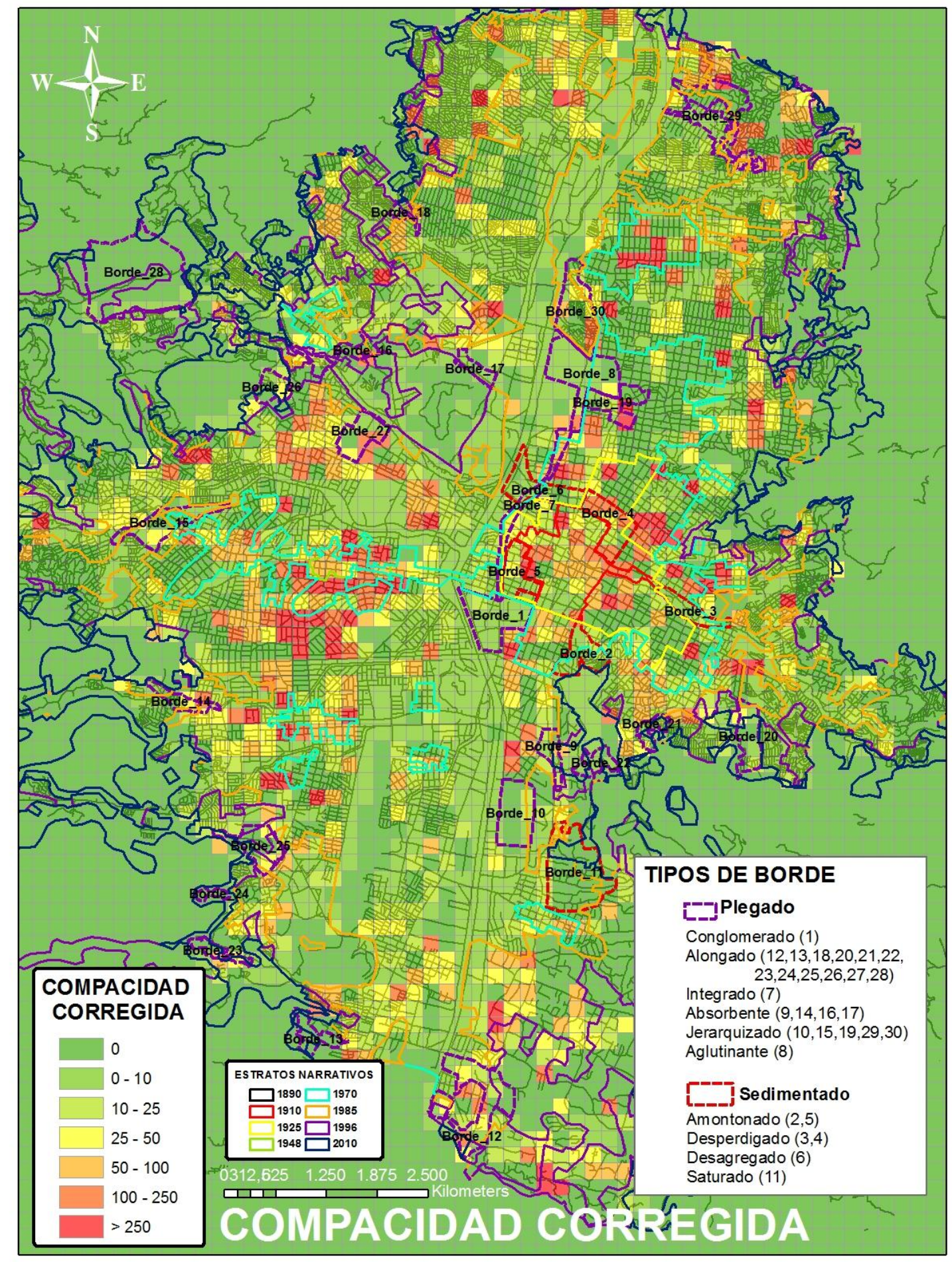

Fuente: ilustración elaborada por el autor con base en datos del POT de Medellín. 
Ilustración 37. Mapa de compacidad ponderada del área urbana de Medellín y su relación con los bordes urbanos

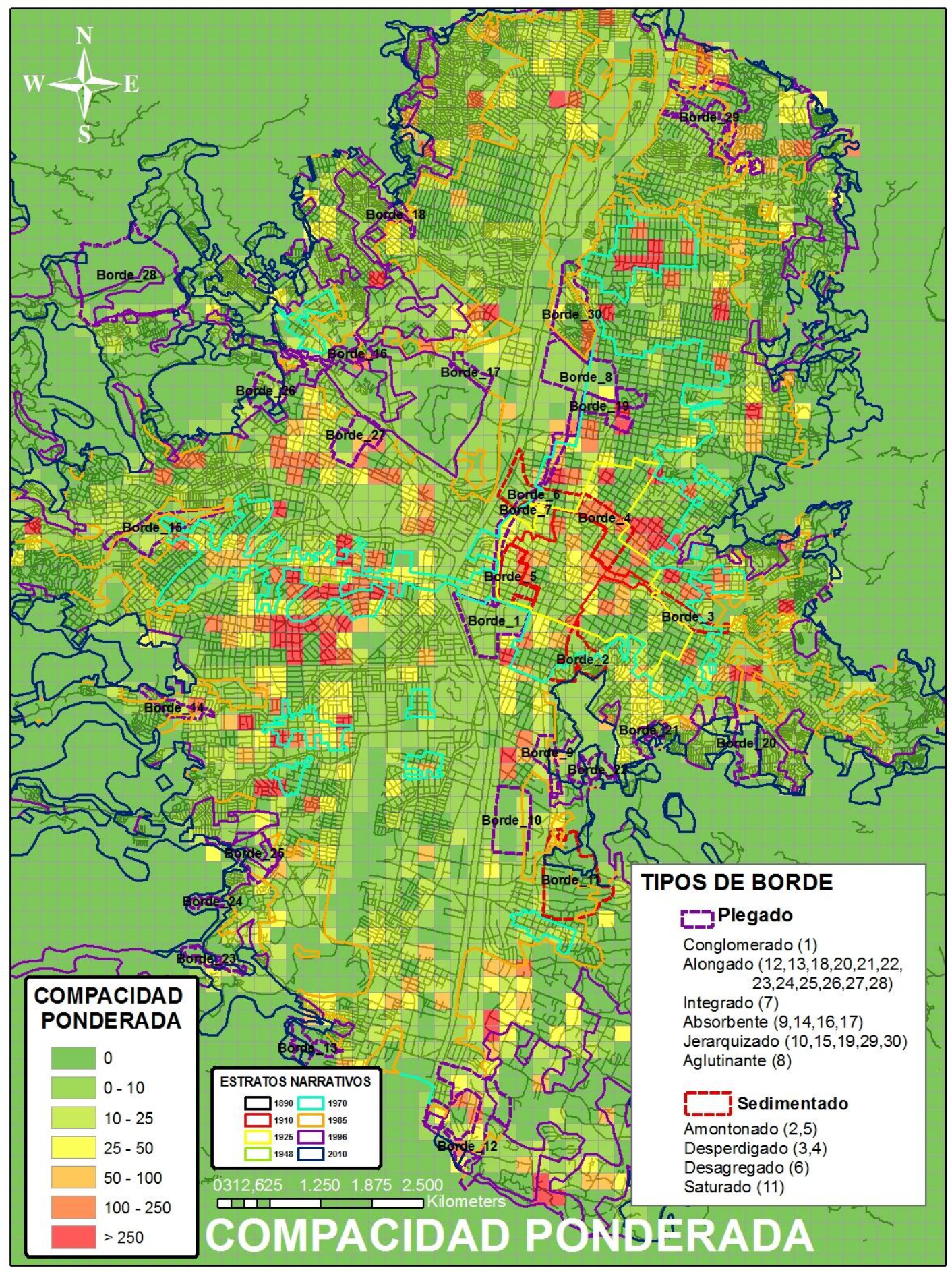

Fuente: ilustración elaborada por el autor con base en datos del POT de Medellín. 
Ilustración 38. Gráficas que muestran las formas que sobre el espacio ejercen los bordes plegados en los subtipos: conglomerado, integrado, aglutinante, jerarquizado y alongado.

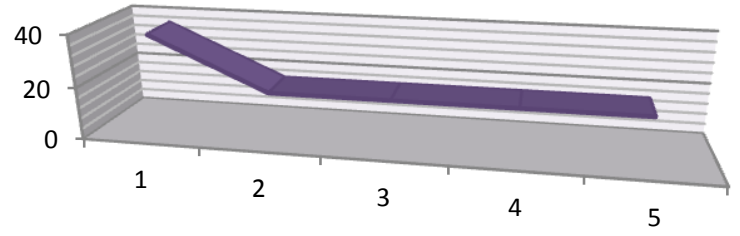

Borde plegado conglomerado (1)

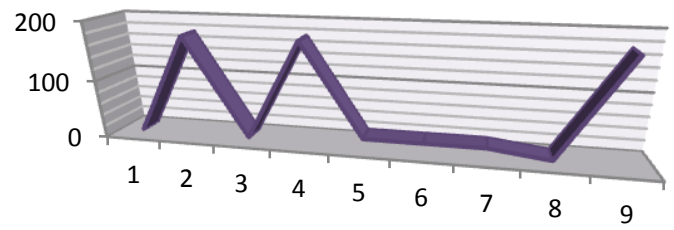

Borde plegado aglutinante (8)

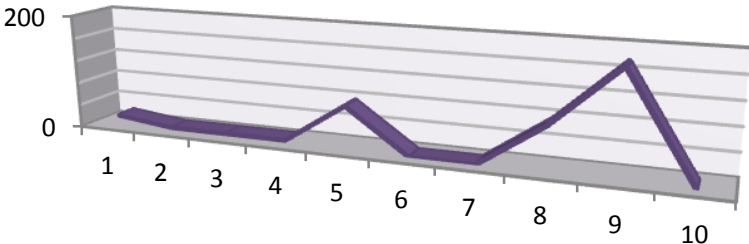

Borde plegado jerarquizado (29)

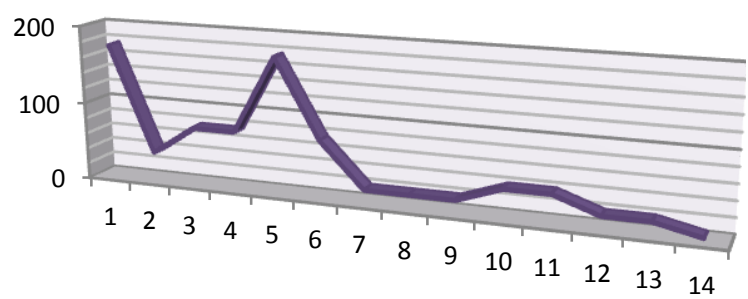

Borde plegado integrado (7)

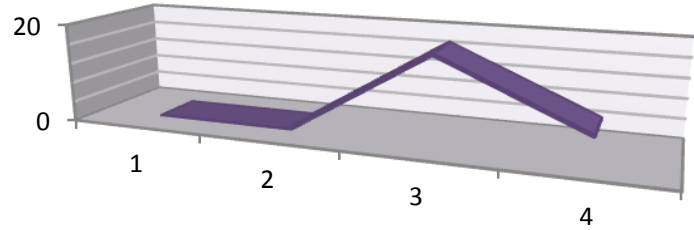

Borde plegado jerarquizado (15)

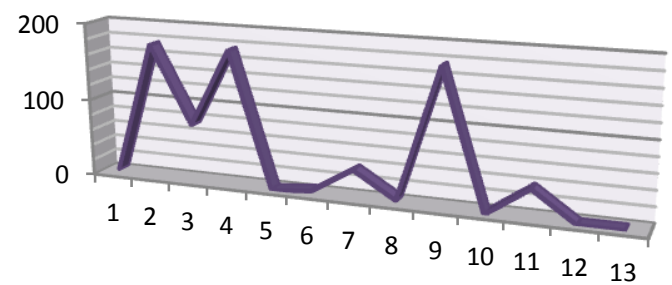

Borde plegado alongado (12)

Fuente: ilustración elaborada por el autor con base en los mapas de compacidad ponderada. 
Ilustración 39. Gráficas que muestran las formas que sobre el espacio ejercen los bordes plegados en los subtipos: alongado y absorbente.

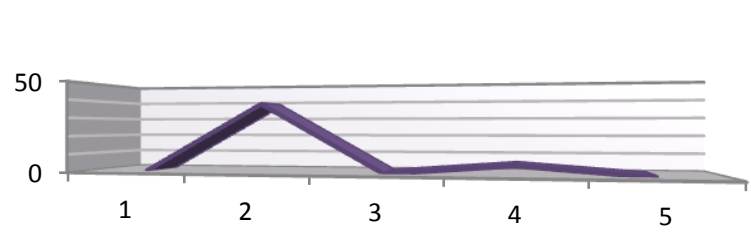

Borde plegado alongado (23)

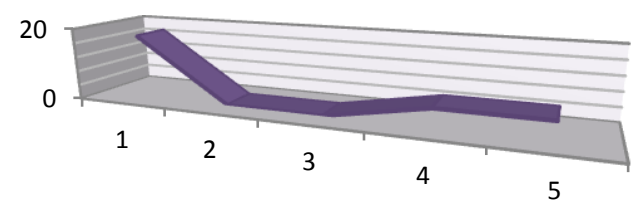

Borde plegado alongado (22)

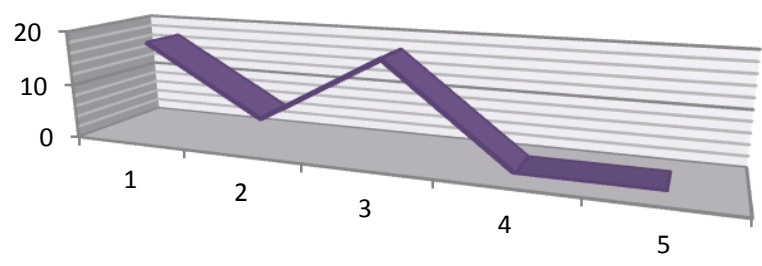

Borde plegado absorbente (9)

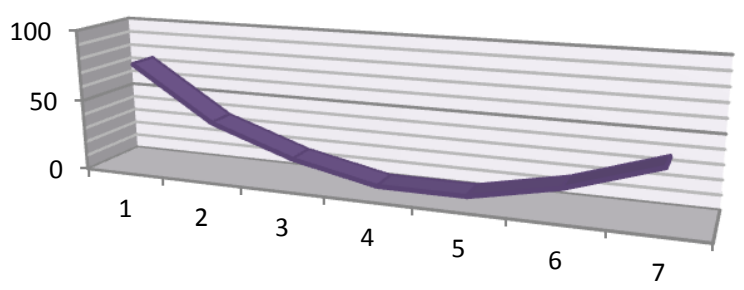

Borde plegado alongado (21)

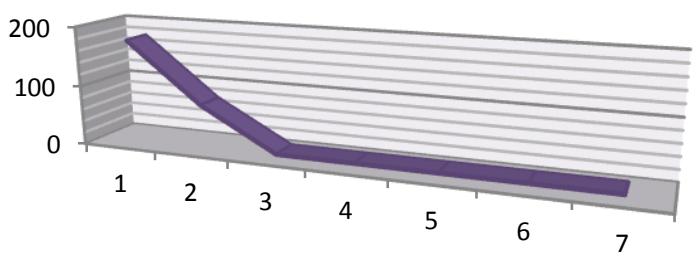

Borde plegado alongado (27)

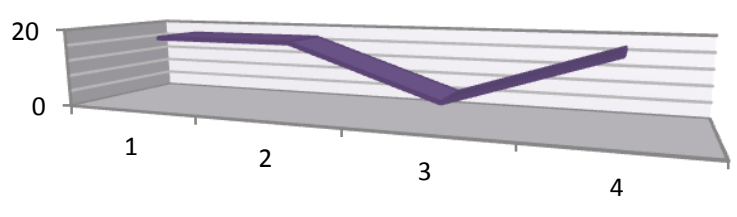

Borde plegado absorbente (16)

Fuente: ilustración elaborada por el autor con base en los mapas de compacidad ponderada.

La ilustraciones 38 y 39 grafican la presión del medio construido (volumen) sobre el espacio urbano de Medellín (área o superficie), resaltando especialmente la acción que ejerce en los tipos de borde plegados. En estas se muestran las diferencias del proceso de transformación que caracterizan a cada uno de los subtipos identificados. Por ejemplo, en el caso del borde plegado conglomerado (1) se evidencia la preponderancia de los espacios ampliamente abiertos (bajos índices de compacidad) como 
principal patrón, asociado al doblez o la cresta que sobre el espacio urbano se ejerce para orientar la mirada de los actores urbanos (altos índices de compacidad).

El borde plegado conglomerado asume las características de una amplia plataforma que contiene los ritos de la cultura civil, en donde el monumento del edificio público atrae todas las miradas, en un culto cotidiano que despeja las inquietudes del ciudadano, quien observa cómo la gran masa se las arrebata y las alza sobre el inmenso cielo que lo cubre. Por otro lado, la gráfica del borde plegado integrado (7) evidencia los corredores azarosos (evidentes saltos entre bajos y altos índices de compacidad, pliegues quebrados y llanos) en que se han convertido algunos de sus ejes estructurantes. Es esta la razón que motiva las recientes actuaciones sobre estos corredores urbanos, a través de los cuales se intenta arrojar un nuevo manto que sortee la amplia diversidad urbana y ponga en orden todo aquello que se salga del guión de una ciudad que insiste en mostrarse perfecta.

La gráfica del borde plegado aglutinante (8) muestra el proceso de doblado que sobre el espacio urbano se está ejerciendo para agrupar componentes que mantenían dinámicas aisladas, $\mathrm{y}$ ahora conforman una superficie que los reunifica. El propósito de las acciones que se efectúan en este plegamiento del espacio es formar una nueva organización con componentes semióticos, que en la ciudad aparecen como separados, bajo la pretensión de construir un nuevo relato urbano que difumine los marcados contrastes que caracterizan a la ciudad.

Las gráficas relacionadas con los bordes plegados jerarquizados (15 y 29) muestran la acción que se ejerce sobre los espacios urbanos construidos bajo lógicas de producción, alejadas de los discursos del poder, para intervenirlas de tal forma que se incorporen al sistema de espacios centrales de la ciudad. Este tipo de plegamientos sobre superficies urbanas ya construidas, intentan reformular la disposición de los objetos en el espacio, procurando que se acerquen a los patrones conseguidos en los bordes plegados conglomerados o aglutinantes. Esto significa la configuración de amplias plataformas para el ejercicio de la conmemoración de los ritos civiles, y la focalización de volúmenes sobre los cuales dirigir la mirada, en señal de fe sobre una transformación que se da en la piel, y aún no, en las entrañas del tejido urbano-social.

Mientras que los pliegues que se observan en las gráficas, relacionados con el subtipo de los bordes alongados, evidencian cómo se viene alargando el espacio urbano sobre áreas periurbanas que se destacan por la baja presión del medio edificado sobre el espacio (superficies de significativa área en las que se incrementa la presión del medio construido en contraste con las características del entorno). Acciones que en algunos casos se ejercen en sectores periurbanos caracterizados por el predominio de la naturaleza, y aledañas a enclaves urbanos de altas densidades habitacionales, de bajas condiciones socioeconómicas, y bajos estándares en las especificaciones infraestructurales.

Por su parte, las gráficas asociadas a los bordes plegados absorbentes muestran la configuración espacial de los sectores de enclave (que se doblan hacia adentro) en los que se insertan componentes que pretenden acelerar procesos de transformación (amplias áreas de la ciudad en donde venían predominando bajos índices de compacidad rodeados por entornos de medio o alta compacidad). El propósito de tales acciones es invertir los valores que dan forma a este tipo de superficies urbanas. 
Ilustración 40. Gráficas que muestran las formas que sobre el espacio ejercen los bordes sedimentados en los subtipos: desperdigado, amontonado, desagregado, saturado.

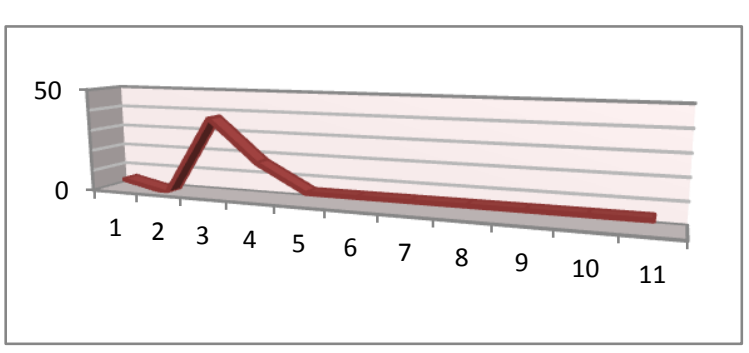

Borde sedimentado desperdigado (3)

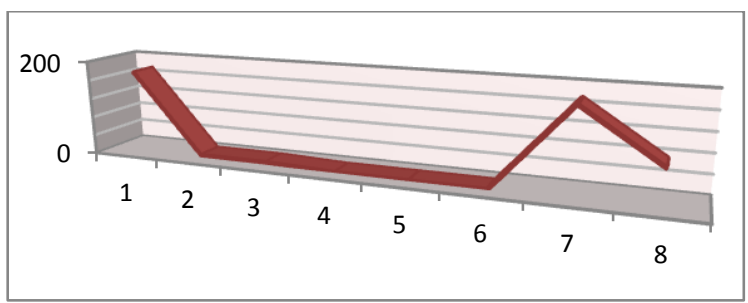

Borde sedimentado amontonado (2)

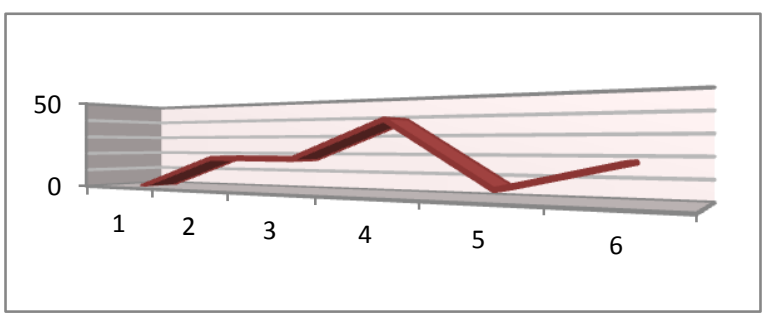

Borde sedimentado desagregado (6)

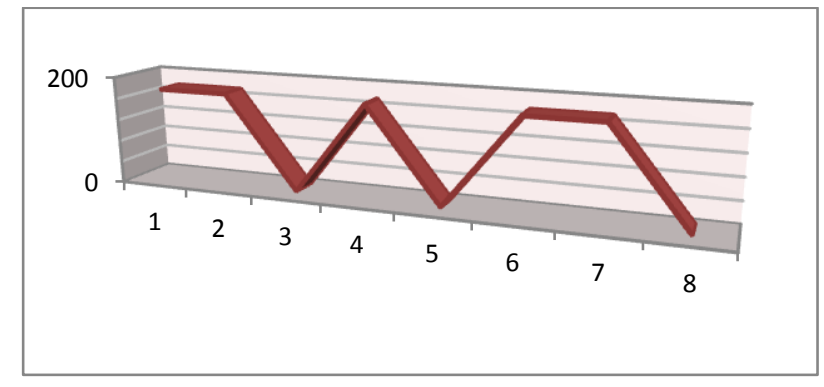

Borde sedimentado desperdigado (4)

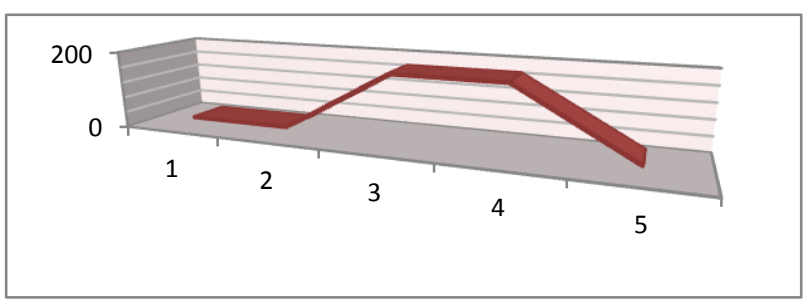

Borde sedimentado amontonado (5)

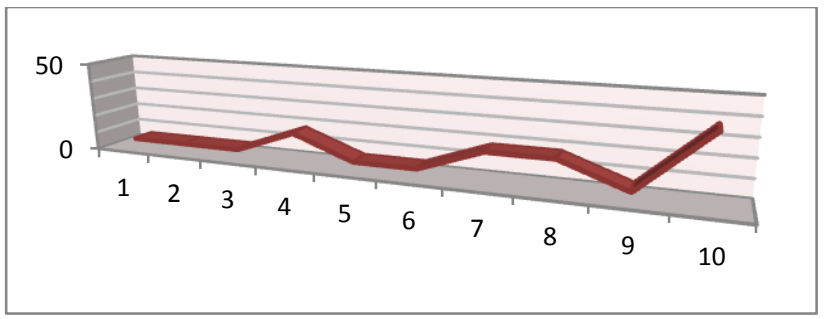

Borde sedimentado saturado (11)

Fuente: ilustración elaborada por el autor con base en de los mapas de compacidad ponderada.

Los tipos de borde sedimentado surgen de las acciones que se ejercen en los bordes de plegamiento, que en sus intentos de territorialización provocan el destierro de componentes que emprenden trayectorias de relocalización en otros sectores de la ciudad, por un lado, o que permanecen adheridos a la superficie discursiva que se transforma, adoptando otros significados que le permitan camuflarse en los nuevos relatos urbanos.

Apreciemos, por ejemplo, cómo la gráfica del borde sedimentado desperdigado (4) muestra que a pesar de la significativa fuerza de transformación que se ejerce sobre el paisaje urbano, esta acción deja algunos reductos que permanecen en la escena como componentes discontinuos o separados de los discursos que dan sentido a su presencia. Por su parte, la gráfica del borde plegado desperdigado (3) indica que el proceso apenas está iniciando en este sector de la ciudad, y que muy seguramente su transformación seguirá los patrones que muestra la gráfica 4.

Las gráficas asociadas a los tipos de borde sedimentado amontonado (2 y 5) muestran cómo la acumulación de componentes desterritorializados de otros sectores inician una evidente presión sobre 
el espacio que encontraron para intentar re-acomodarse, que por tener diferentes orígenes discursivos no logran hilar de forma conjunta un relato urbano consecuente. En este tipo de bordes los componentes que llegan fácilmente pueden ser expulsados por la presión que ejerce el continuo amontonamiento de otros componentes.

A su vez, las gráficas que se relacionan con los bordes sedimentados desagregados muestran cómo la acción que se ejerce sobre el espacio urbano para el confinamiento de componentes no tolerados en los escenarios de la representación del poder, reelaboran nuevos encadenamientos para dar sentido a trayectorias cortas, que siguen los exiliados urbanos. Esto se deduce de las suaves transiciones entre los espacios que mantienen bajas presiones del medio construido con las que muestran considerables influencias del volumen edificado sobre el espacio. Lo que además se constata es su aislamiento de los demás relatos, en donde predominan los componentes simbólicos de los discursos predominantes (significativos saltos de compacidad baja a media o alta).

Finalmente, las gráficas asociadas a los bordes sedimentados saturados revelan superficies urbanas de carácter más inestable, por la fuerte introducción de componentes que ejercen una alta presión sobre el espacio, dejando en situaciones fluctuantes a los elementos que caracterizaban el paisaje. La conjunción entre los nuevos y los viejos componentes conforman escenas cargadas de estrechez y apretujamiento.

\subsubsection{La complejidad urbana en los tipos de borde urbano}

Las teorías de la sostenibilidad urbana han venido destacando el valor de la ciudad compacta, que entre sus principios menciona el acompañamiento de la residencia con los servicios urbanos. Esto, insisten, revitaliza el escenario de la calle, por la atracción que genera la diversidad de actividades, y por otro lado, reduce la gestión del recorrido de amplias distancias para que los ciudadanos se sirvan ante sus demandas. Los índices de complejidad urbana son un instrumento de interpretación para representar recomendaciones de carácter proyectual basadas en el movimiento de la forma y la función de la espacialidad en su sustrato material.

El índice de complejidad urbana se emplea en esta investigación para constatar cómo las actividades urbanas diferentes al uso residencial, marcan la superficie urbana incidiendo en los trayectos de memoria que re-corren los ciudadanos en su cotidianidad. Para tal propósito se acude a las bases de datos del Plan de Ordenamiento Territorial de Medellín, específicamente a lo referido a la información jurídica de la base catastral, información que permite diferenciar los usos destinados en los predios que conforman los primeros pisos de la ciudad.

La espacialización de este índice, para confrontarlo con la identificación de los tipos de borde urbano, se hace a través de dos mapas. El primero, Número total de personas jurídicas en primer piso, sirve como base para distinguir las áreas de la ciudad que se caracterizan por soportar intensas actividades urbanas. El segundo, Complejidad urbana por porcentaje de actividades de proximidad, muestra la proporción de actividades de carácter barrial y vecinal de personas jurídicas que ocupan la planta urbana de la ciudad. Para el cálculo de ambos casos se emplea la misma grilla de 200 x 200 metros, que sirve también de base en los mapas de compacidad. 


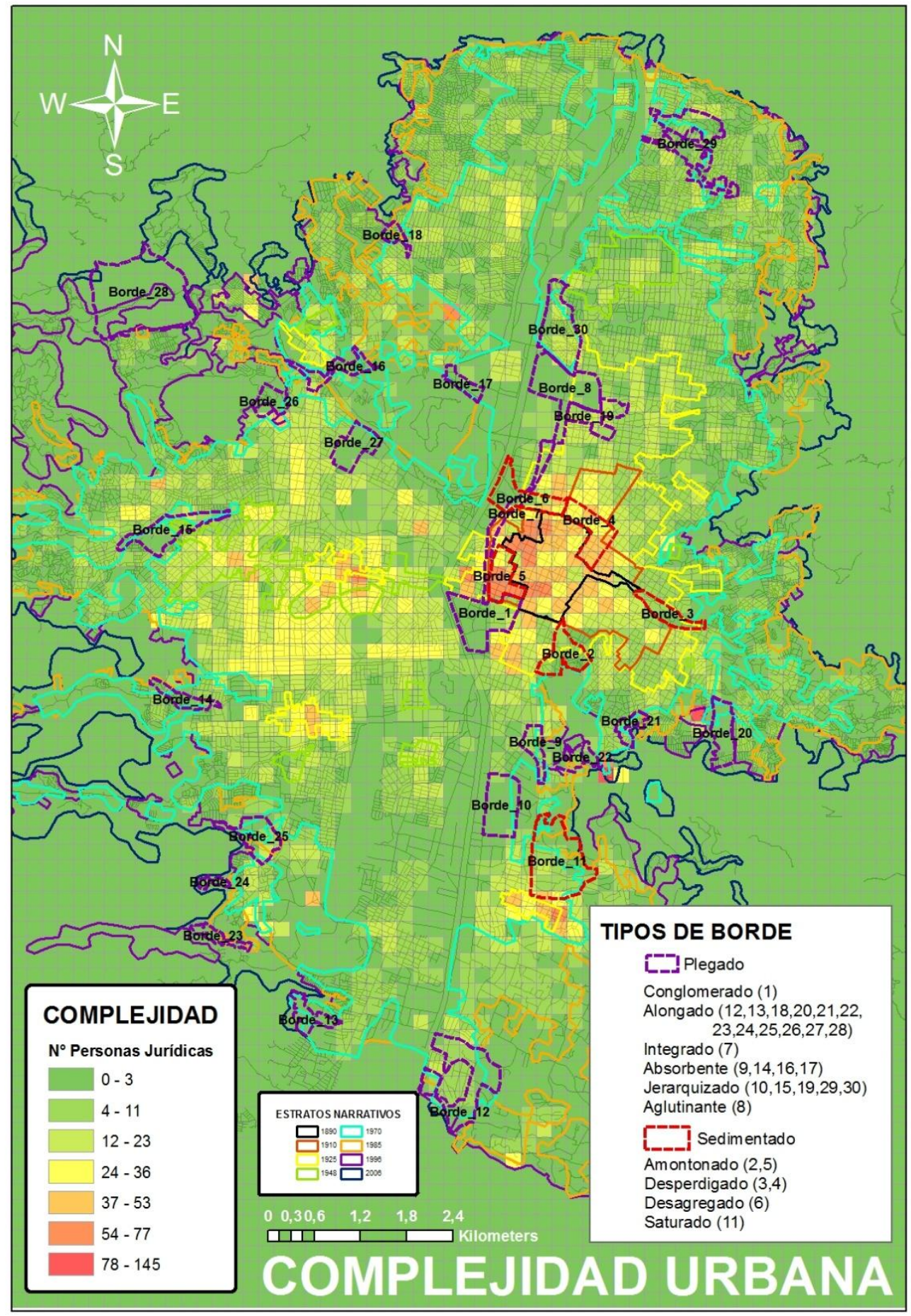

Fuente: ilustración elaborada por el autor con base en datos del POT de Medellín. 
El segundo mapa se elabora a través de una fórmula en la que se divide el número de actividades de proximidad $^{52}$ sobre el total de actividades jurídicas del primer piso, por el área de referencia (200 x 200 metros) y por cien para obtener así el porcentaje. Con la base de datos disponible, es posible diferenciar las actividades de proximidad, es decir, de escala vecinal y barrial con las siguientes categorías que discrimina la base catastral del Plan de Ordenamiento Territorial de Medellín (Acuerdo 046 de 2006): locales, restaurantes, teatros, gimnasios, guarderías, colegios, plazas de mercado, centros culturales, supermercados y consultorios.

Según Salvador Rueda, una determinada densidad de actividades se convierte en un elemento clave para garantizar unos valores mínimos de complejidad urbana. Este tipo de enfoques, derivados de la ecología urbana, insisten en que la planificación de las ciudades debe: “(...) potenciar la calle corredor y el frente de calle en planta baja, eliminando huecos y aquellas actividades creadoras de desierto o vacío urbano" (Rueda, 2007).

El primer mapa (Ilustración 39) revela cómo el mayor número de personas jurídicas (servicios urbanos) se concentran en la zona núcleo de la ciudad (estrato narrativo de 1890 y 1910), área que coincide con una fuerte dinámica de transformación, caracterizado tanto por bordes plegados y sedimentados. Esta situación vislumbra posibles movimientos de desterritorialización de varios componentes que sostienen la agitada actividad del núcleo de la ciudad, frente a las pretensiones de los tipos de borde plegado, específicamente en sus subtipos conglomerado e integrado.

La insistencia de los bordes plegados de ampliar sus áreas de influencia no sólo sitia a los bordes sedimentados, sino que ejerce tal presión sobre los mismos, que varios componentes reanudan nuevamente movimientos de exilio sobre áreas cercanas a la zona núcleo, que ya han iniciado la delimitación de áreas para su subsistencia. Esta situación de desplazamiento de componentes semióticos y la introducción de otros nuevos, desde el punto de vista de la complejidad (diversidad) urbana se aprecia en la pérdida de actividades de proximidad (de carácter vecinal y barrial) y en el incremento de actividades de mayor representatividad a escala de ciudad y de metrópoli.

La ilustración 25 muestra cómo es en esta zona donde en los últimos años se ha incrementado el valor del suelo de una manera sustancial, a tal punto de ser una de las áreas más costosas de pagar para la localización de cualquier actividad. Situaciones que comienzan un tránsito similar en el centrooccidente y suroccidente de la ciudad (Laureles y El Poblado), estas dos últimas que gozan de alto prestigio en el imaginario colectivo, ya que han sido asiento de las clases socioeconómicas de mayor ingreso y calidad de vida en la misma proporción.

52 "Las actividades de proximidad son aquellas actividades económicas de uso cotidiano donde el ciudadano accede en función de la proximidad de su residencia. Se engloban dentro de esta categoría las actividades clasificadas en los sectores de la alimentación, libros y periódicos y productos químicos y farmacéuticos. La presencia de estas actividades indica que el tejido urbano es especialmente apto para ser habitado, que dispone de equipamientos y de los recursos y servicios necesarios para hacer vida en la calle. Por el contrario, las áreas urbanas sin actividades de proximidad supone para sus habitantes un coste elevado de desplazamiento para la realización de las tareas diarias y actividades comunes". (Rueda, 2007: 42) 


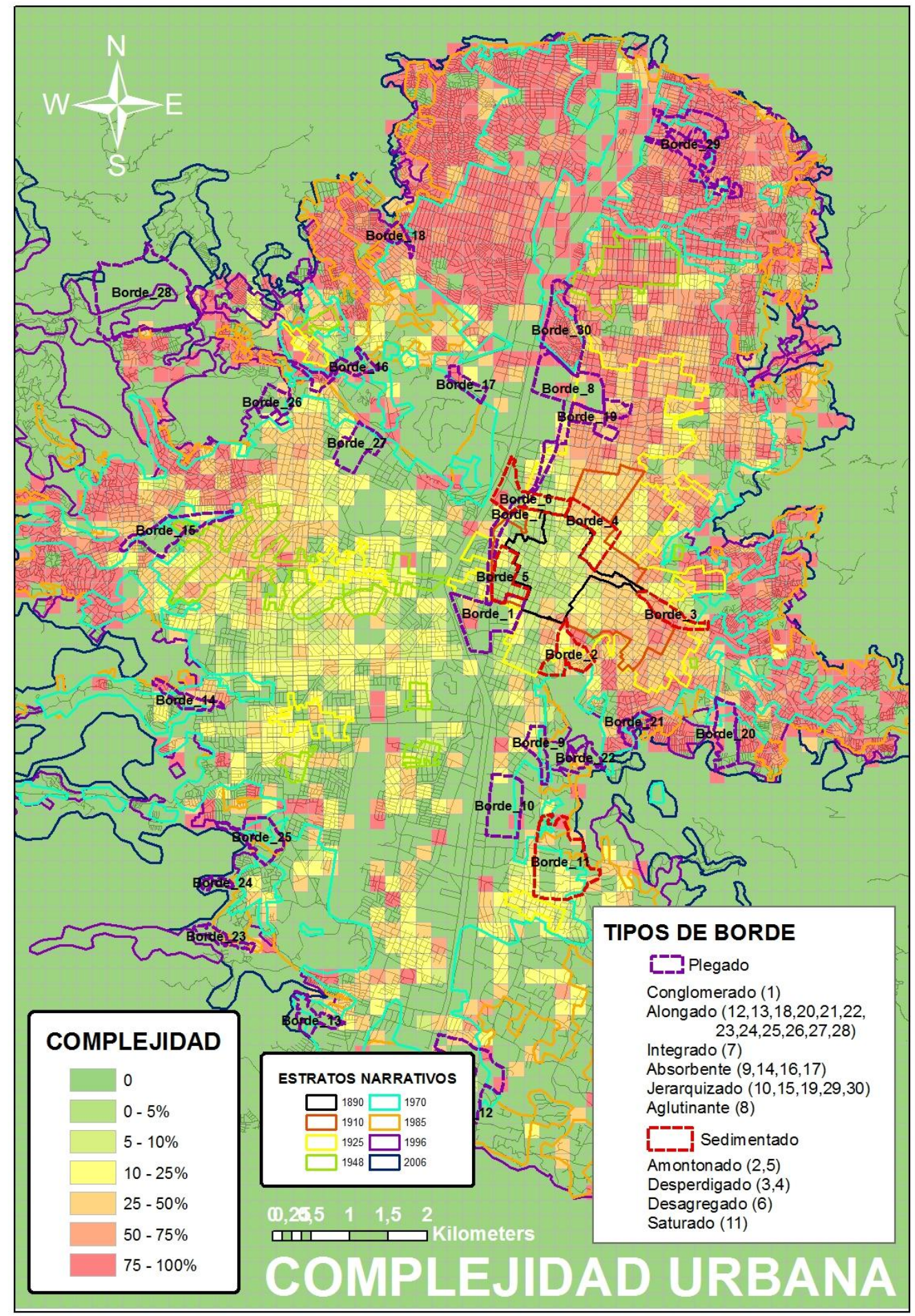

Fuente: ilustración elaborada por el autor con base en los datos del POT de Medellín. 
La zona núcleo de la ciudad muestra un proceso de transformación, en el que a pesar de tener el mayor número de personas jurídicas por área (Ilustración 41), su complejidad en cuanto al porcentaje de actividades de proximidad es una de las más bajas (Ilustración 42), lo que indica como la diversidad de actividades está siendo sustituida por la especialización de algunas funciones urbanas, además de una escala predominantemente metropolitana, como es el caso de los servicios institucionales

La insistencia para recuperar la representatividad de la zona núcleo de la ciudad, y erradicar las actividades que sostienen una agitada dinámica urbana, sustituyéndolas por la modelación de amplios espacios y volúmenes ceremoniales, ha producido un efecto contrario, el de atraer una numerosa población que nomadiza la metrópoli en ritos de conmemoración, que no la estabilizan ni le garantizan su permanencia en la ciudad como residentes.

Entre muchos propósitos existentes en el Plan de Ordenamiento Territorial de Medellín sobresale uno: que la vivienda regrese a la zona núcleo. Sin embargo, las actuaciones que se han venido generando dentro del centro de la ciudad continúan expulsando las actividades de proximidad que son las que sostienen, por su escala, los itinerarios que los ciudadanos siguen para encontrarle sentido a las escenas cotidianas, que acompañan sus lugares de residencia.

\section{Ilustración 43. Ocupación del uso residencial en relación a la zona núcleo de la ciudad}

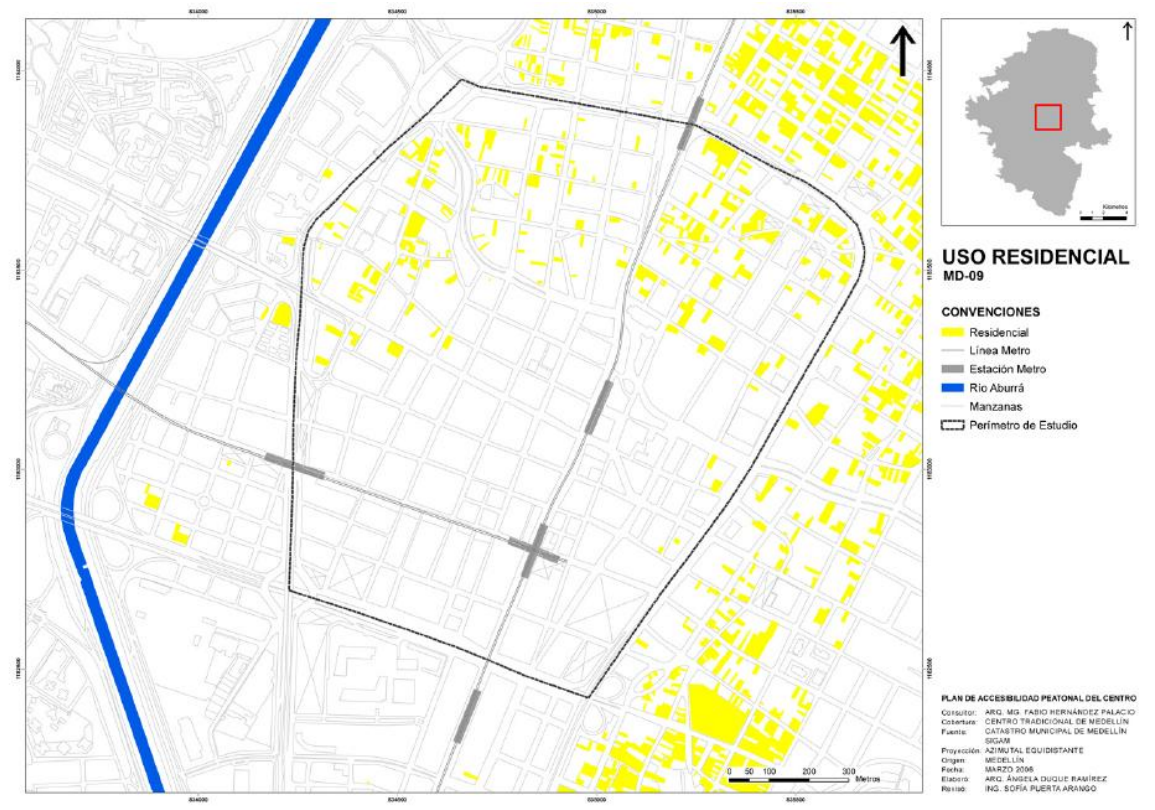

Fuente: Plan de Accesibilidad Peatonal del Centro de Medellín, 2006.

Por su parte, se aprecia que en los bordes plegados aglutinante e integrado, atraviesan corredores que con una notada diferencia de complejidad urbana vienen sufriendo procesos de transformación. Los intentos de ordenación de estos corredores muestran ir en el mismo sentido que el caso expuesto en la zona núcleo. Sustituir las actividades de proximidad, a los residentes más cercanos, por otras actividades que atraigan al gran conjunto de la población metropolitana.

En contraste se muestran las áreas periféricas, en donde el número de personas jurídicas por área es menor, pero el porcentaje de actividades de proximidad es mayor. Y curiosamente, es sobre estas áreas 
en donde los tipos de borde que inician el proceso de transformación son plegados y del subtipo alongado. Es decir, la incorporación de morfologías cerradas, de alta densidad constructiva, pero con una muy baja integración urbana. Este tipo de transformaciones no aprovecha aún la oportunidad para localizar servicios de gran escala e impacto, para sectores caracterizados por altas densidades habitacionales, con un número muy bajo de servicios y equipamientos, y los que existen, en su gran mayoría no superan las coberturas vecinal y barrial.

Ilustración 44. Densidad habitacional por barrio, 2009

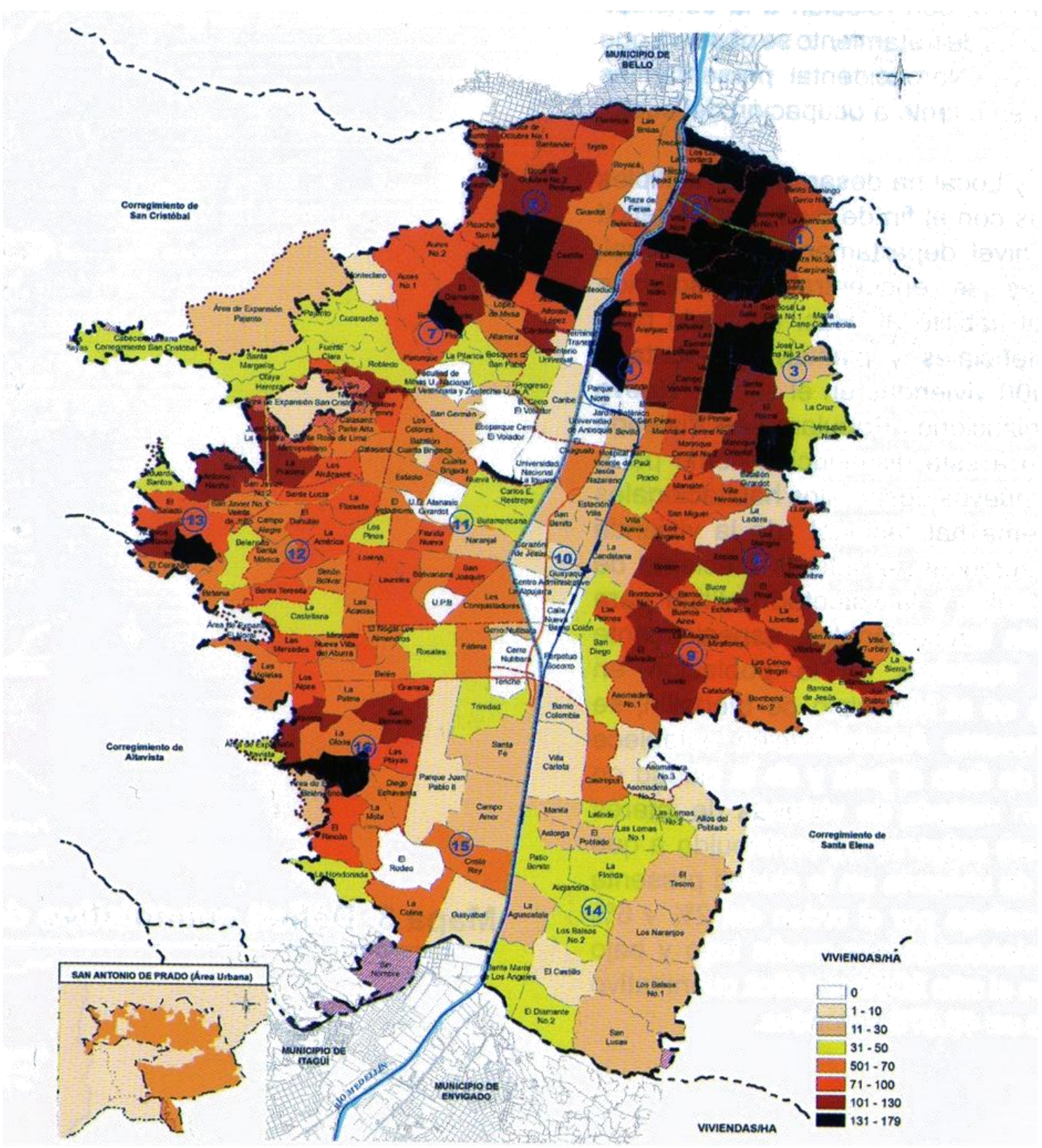

Fuente: DAPD (2010). “Medellín en cifras”, Medellín.. 
Mientras que las áreas que muestran niveles medios de actividades jurídicas por área (200 x 200 metros) en primer piso, es decir, entre 24 y 53 predios dedicados a servicios urbanos (Ilustración 39) coinciden en gran medida con niveles medios de porcentajes de actividades de proximidad, entre el $10 \%$ y el $50 \%$ están sufriendo procesos de transformación dominados por tipos de bordes sedimentados saturados. Este tipo de transformación sobre áreas urbanas consolidadas viene reemplazando componentes que sostienen niveles más óptimos de sostenibilidad urbana, y a su vez, esquemas de memoria expeditos y claros, por componentes que inician procesos de desarticulación urbana y de ensimismamiento.

\subsubsection{Análisis axial en relación con los bordes urbanos}

Como ya se mencionó en apartados anteriores Bill Hillier y un grupo de alumnos con sede en The Bartlett, Londres, en la década de los ochenta del siglo XX, desarrollaron un tipo de análisis que facilita el estudio de las relaciones que se establecen en las ciudades, dependiendo de los niveles de integración. Para tal efecto, este grupo de investigadores han desarrollado programas computacionales que permiten graficar la articulación de las relaciones sociales, empleando entre varios aspectos, los trayectos que permiten la comunicación entre los ciudadanos.

El mapa axial es una de las herramientas que permite realizar análisis de integración o de accesibilidad. Teniendo disponible la malla urbana sobre la que se sostienen las movilidades vehicular y peatonal, en formatos vectoriales como el CAD, gracias al cual, es posible migrar la información a los programas desarrollados por Hillier y otros investigadores, quienes incluso facilitan acceder a este tipo de software de forma gratuita por Internet (UCL, Bartlett School of Graduate Studies, disponible en: http://www.vr.ucl.ac.uk/depthmap/).

Existen antecedentes en la planificación urbana de Medellín que han venido aprovechando este tipo de herramientas, a las cuales acudimos para continuar averiguando las implicaciones que tiene la transformación del paisaje, tal y como se aprecia en los tipos de borde urbano identificados (Ilustraciones 45 y 46). Los mapas de accesibilidad vehicular y peatonal de Medellín, elaborados en el 2003, son un registro adicional de los moldes espaciales que disponen los actores urbanos para restituir la memoria de sus actos, de forma cotidiana sobre el espacio urbano.

El mapa de integración de la accesibilidad vehicular (Ilustración 45) nos muestra cómo la zona núcleo tiene los más altos índices, que permiten deducir la continua y constante relación de este sector urbano con el resto de la ciudad y el área metropolitana. Situación que se reduce ostensiblemente al revisar este mismo sector en el mapa de integración de la accesibilidad peatonal (Ilustración 46). Esto nos permite indicar que en la zona núcleo los esquemas de memoria refuerzan no sólo el predominio visual de la arquitectura monumental, sino a su vez recorridos largos que por su velocidad incentivan experiencias de corta duración.

Aunque debe reconocerse que algunas de las operaciones que se ejercen sobre los bordes de pliegue integrado intentan rescatar la vivencia a escala más local, promoviendo escenas de revitalización urbana protagonizadas por el peatón. Lo que sí es claro es que estas transformaciones se concentran en corredores en donde tienen mayor representación los discursos de poder. 
Por otro lado, los mapas axiales nos permiten llamar la atención sobre aquellos sectores en donde coinciden los bajos índices de integración de accesibilidad vehicular y peatonal, sobre los cuales se está ejerciendo una considerable fuerza de transformación (bordes urbanos plegados alongados), que desafortunadamente en vez de revertir tal situación consolidan propuestas de segregación urbana, ya que los proyectos que se vienen erigiendo lo hacen a través de morfologías irregulares y cerradas.

Entre los sectores que gozan de altos y muy altos niveles de integración en la accesibilidad vehicular y peatonal, situados en el centro-occidente y centro- oriente, cercanos al núcleo de la ciudad, se produce una configuración espacial, que facilita a sus actores consuetudinarios recrear itinerarios amplios y con un sentido que valora la construcción cotidiana de narrativas urbanas; sin embargo, los significativos procesos de densificación promovidos por las empresas inmobiliarias y estatales (bordes sedimentados saturados) arrebatan sus cualidades estéticas, deteriorando los escenarios del paisaje urbano. 
Ilustración 45. Mapa axial. Análisis de integración de la accesibilidad vehicular

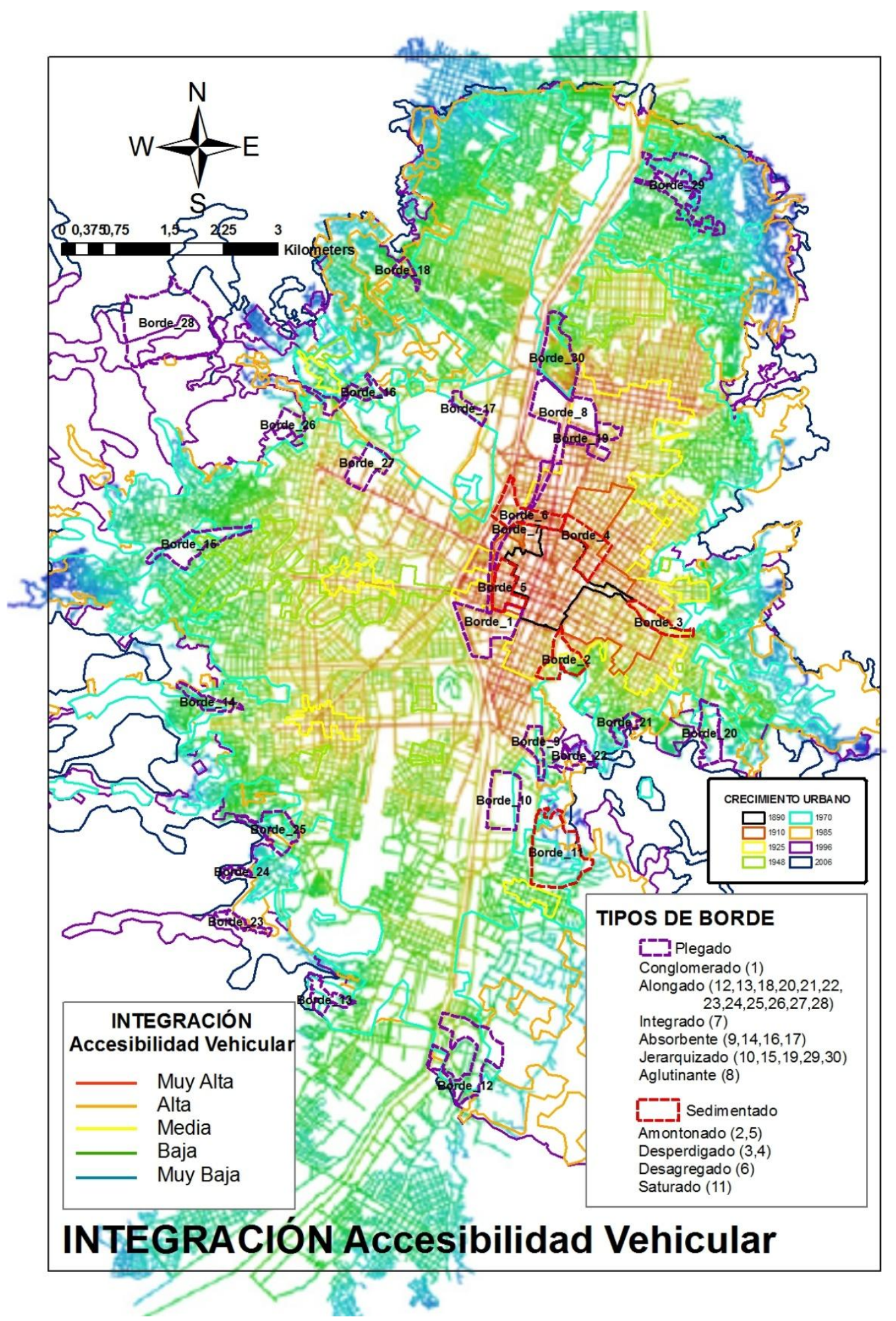

Fuente: ilustración elaborada por el autor con base en u mapa de: F. Hernández (2003). Reconnections and Recognitions, urban renewal in the central area of Medellín Colombia. Holanda: Universidad Técnica de Delft. 
Ilustración 46. Mapa axial. Análisis de integración de la accesibilidad peatonal

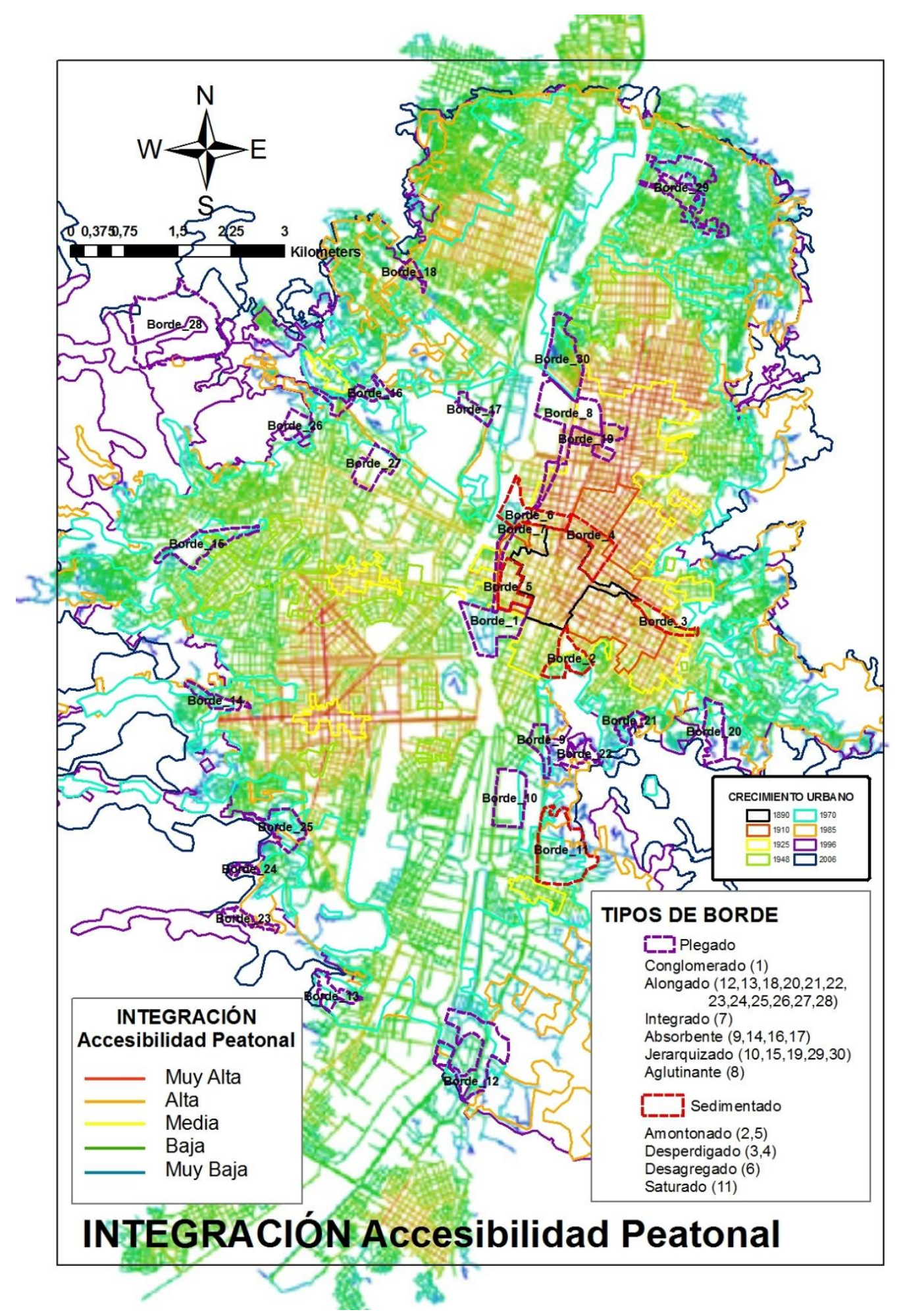

Fuente: ilustración elaborada por el autor con base en u mapa de: F. Hernández (2003). Reconnections and Recognitions, urban renewal in the central area of Medellin Colombia. Holanda: Universidad Técnica de Delft.. 


\section{CAPÍTULO 4. CONCLUSIONES DE LA INVESTIGACIÓN}

\section{POR UNA GESTIÓN DE LA TRANSFORMACIÓN DEL PAISAJE}

El recorrido que hemos realizado a través de las derivas del borde urbano de Medellín, nos ha permitido acercarnos a las lógicas de producción del paisaje, y poner en lenguaje académico las consecuencias y secuelas de su transformación.

La producción inmobiliaria de la ciudad, evidencia conflictos del funcionalismo espacialista con la estructura de memoria, que es la que facilita el reconocimiento y la comunicación entre los ciudadanos, para recrear una imagen viva de su ciudad, y mantener vigente el gesto del actor urbano en una historia que actualiza y plasma los imaginarios, tejiéndolos con sus contextos actuales, y armonizando la inquietud de la imaginación con los movimientos sociales que transgreden la imagen y la vida del paisaje.

Lynch (1992) ya había insistido que las exigencias en la configuración del espacio urbano van más allá del carácter funcional, y de sus aspectos estéticos, por su directa implicación con las transformaciones que provoca la cultura. Es por esto que la ciudad afronta los cambios que determina el paso del tiempo, intentando estabilizar las tensiones entre los componentes considerados como viejos y aquellos otros que movilizan nuevos valores, e intentan recolonizar los dominios del espacio y del tiempo, modificando los itinerarios de los actores urbanos, en diferentes trayectorias que es necesario actualizar con una postura crítica.

En el medio académico colombiano, la transformación del paisaje ha carecido de preocupaciones teóricas y metodológicas que se ocupen de las lógicas que intervienen en su movimiento y dinamismo estructural y formal, y que aporte conocimiento para orientar una política del cambio, de tal manera que asegure experiencias paisajísticas dotadas de sentido y valor para la amplia y diversa gama de actores urbanos. Una transformación del paisaje sin una gestión del cambio viene ocasionando la erosión de la vivencia memorial de los espacios y los tiempos, porque han incorporado sus fuerzas creadoras en los itinerarios, habituados y sensibilizados por los ciudadanos, incentivándolos a narrar sus trayectos con un sentimiento de evocación y proyección en un tiempo histórico abierto.

Los problemas en la ciudad surgen en gran medida cuando se pretende reducir la riqueza que plantea la diversidad de actores urbanos, intentando para esto, definir piezas uniformes para la modulación del espacio y del tiempo. También estos aparecen, cuando en el proceso de transformación se impide abruptamente la transmisión de información que producen las experiencias de cada generación, y que constituyen las improntas de cada estrato narrativo que forman parte del proceso de crecimiento de la ciudad.

La gestión del paisaje, basada en una teoría narrativa que intenta comprender el proceso de transformación de la ciudad, debe reconocer la polifonía que le plantea el panorama contemporáneo. Para tal propósito, la gestión del paisaje debe atender especialmente las tendencias de cambio que se están evidenciando en los procesos de transformación de mayor dinamismo, y que tienen lugar en los bordes urbanos, que como se explicó en el transcurso de esta investigación, se constituyen en las rupturas que muestra la superficie discursiva del paisaje urbano. 
La gestión del paisaje contemporáneo, basado en una teoría narrativa, deberá plantearse la tarea de proponer un sistema de memoria urbana, que empleando la semántica de los componentes que hacen parte de la ciudad, conformen una sintaxis y una gramática urbana que faciliten la lectura y la orientación de los actores urbanos dentro de los espacios y los tiempos, que debidamente modulados, construyan un paisaje de imágenes nítidas y esclarecedoras.

Una gestión del proceso de transformación del paisaje formulará escenarios evolutivos, en los que sea posible codificar, transmitir y ajustar la información que ha acumulado la ciudad en su proceso de crecimiento y expansión. Esta postura por supuesto, pone en crisis la producción regular del tiempo y del espacio que propone la planificación urbana, y promueve en cambio, la construcción de escenarios culturales y sociales que bajo esquemas más flexibles, variables y creativos, recuperen la información registrada previamente en la ciudad (memoria) con la que viene incorporándose a través de las nuevas relaciones, para desplegar así un paisaje revolucionario y que se revela.

Este último capítulo intenta destacar cuáles han sido los procesos de transformación más palpables en el paisaje urbano de Medellín. Las conclusiones que a continuación se presentan procuran mostrar cuáles son los desplazamientos de forma y significado que el borde como vector ha direccionado sobre el paisaje urbano de Medellín, en un esfuerzo de síntesis de lo ya apreciado en las categorías estéticas propuestas para diferenciar los tipos de borde urbano. Desde una postura crítica, este corolario de la investigación pretende abrir un debate en relación a cuáles deberían ser los criterios a considerar para fundar las bases de una gestión de la transformación del paisaje urbano.

\subsection{El mosaico de imágenes que nos ofrece la transformación del paisaje de borde urbano}

En un ejercicio de lectura no lineal, se ofrece un panorama que facilita hacer los saltos entre las imágenes de la historia urbana, que configuran distintos estratos narrativos del paisaje, y las imágenes que con decidida fuerza están colonizando la transformación de Medellín, y que vienen dinamizando los procesos de cambio en los bordes urbanos. Estamos apreciando en la ciudad cómo el repertorio de imágenes se está modificando, en algunos casos (tipos de borde) con una denodada aceleración. Por tal razón, es necesario hacer evidentes los cambios que están aconteciendo en la configuración del paisaje urbano, y desde una posición crítica, a través de la teoría narrativa expuesta, dilucidar algunas líneas para la gestión del paisaje contemporáneo.

\section{- Del paisaje arborescente al paisaje absorbido por el concreto. $O$ del parque burgués al parque temático}

Como apreciamos en los antecedentes de esta investigación, así como en la caracterización de los estratos narrativos del paisaje de Medellín, el crecimiento de esta ciudad es impulsado por la burguesía a finales del siglo XIX y principios del XX. Estos emprendedores del crecimiento y el desarrollo acompañan los grandes proyectos de urbanización, con la incorporación de artefactos culturales, como 
el parque y el bosque urbano, ${ }^{53}$ para la disipación de las significativas masas de obreros y empleados de oficinas y almacenes, quienes ocuparían los barrios que se construyeron al norte y oriente respecto al núcleo central.

Los bosques urbanos, incluso el mismo parque, provenientes como componente y recurso urbano de la ciudad europea, e impulsados por movimientos ${ }^{54}$ que se oponían a la transformación que iniciaba la industrialización, curiosamente son traídos a Medellín por la clase burguesa local como un símbolo más del tren del progreso en el que se embarcaban.

El bosque urbano y el parque, como tipologías del espacio público de una ciudad que en su momento iniciaba un proceso franco de expansión, estaban constituidos fundamentalmente por una estructura arborescente que mantenía un vínculo entre la ciudad y la naturaleza, su distribución y disposición en el espacio urbano los convertía en el principal enlace de los relatos que se entretejían en el ahora extenso escenario urbano.

Después de varias décadas, en las cuales el crecimiento urbano de Medellín hasta la actualidad alcanza proporciones inimaginables, el incremento de las áreas verdes acondicionadas como públicas no es, desafortunadamente, proporcional a la presión edificatoria.

En los últimos doce años (a partir del momento en que se adopta el Plan de Ordenamiento Territorial de Medellín) se han venido realizando acciones públicas y privadas intentando reducir la brecha de

53 “Según relatos de la época, surgió allí el primer hipódromo de la ciudad, con una pista doble de carreras de caballos. Aprovechando las aguas existentes se creó un lago donde los visitantes podían pasear remando en barcas. Cerca se construyó un edificio para el bar, el restaurante y la pista de baile. En lo que hoy es el Salón Restrepo, un sitio de eventos, funcionaba una pista de patinaje. Además, el Bosque de la Independencia contaba con vivero, canchas de tenis, trencito, juegos infantiles, un incipiente zoológico y hasta el servicio de venta de animales domésticos (perros y gatos).

Las historias se multiplicaron y se inscribieron en la memoria de los habitantes de la época. El Bosque fue escenario de las celebraciones patrias, sede de competencias náuticas y de pesca, centro de carreras de encostalados y concursos con vara de premios, epicentro de retretas y de representaciones teatrales o folclóricas que se hacían cuando existía la concha acústica. La ciudad entera se encontraba en este sitio, considerado desde entonces como un verdadero espacio público, al que asistían las familias de alta capacidad económica y también las de los trabajadores y obreros. Mientras los niños paseaban en burritas, los adultos se entregaban a otras diversiones como el baile que comenzaba a la una o dos de la tarde y se prolongaba hasta el anochecer" (Jardín Botánico, disponible en: http://www.botanicomedellin.org/historia.html. Consulta: 1 de agosto de 2011).

54 "Rousseau (...) transformó el bosque en un retiro para los decepcionados de las civilizaciones y el progreso y, sobre todo, afirmó una fe invencible en la excelencia de los mitos de la naturaleza. El movimiento literario romántico consagró el bosque como cuadro romántico, propicio para las meditaciones y las emociones contemplativas" (Donadieu, 2006:71). 
espacio público por habitante, según estándares internacionales. ${ }^{55}$ Sin embargo, se aprecia en estas intervenciones cómo la naturaleza es sustituida por prótesis de carácter mineral transformado, empleado para los nuevos montajes de parques temáticos que pretenden escolarizar al ciudadano, pautando los comportamientos que deben guiar sus trayectorias.

Es por esto que aseguramos que del paisaje arborescente que sostiene escenarios para la disipación, que requiere la concentración de significativas masas, y que facilita la aparición de encuentros y actos colectivos, dictados por la espontaneidad, estamos pasando a un paisajismo refractario, que además recrea montajes para un actor concebido como un autómata, pues hasta sus conductas son dominadas por lo artificioso.

Este tipo de transformación se aprecia especialmente en los bordes urbanos plegados conglomerado, aglutinante, integrado y jerarquizado. A pesar de que cada uno de estos tipos de bordes se caracterizan por procesos particulares de transformación, tienen en común que persiguen moldear escenarios en donde la arquitectura por sí misma, como imagen, pretende sustituir al urbanismo y al paisaje, recreando escenarios para atraer a los ciudadanos, que al conglomerarse en grupos de reunión, evitan el contacto.

\section{- El proyecto inmobiliario contemporáneo. Un paisaje sin un proyecto político y sin una propuesta hacia lo público}

En la caracterización de los estratos narrativos pudimos visualizar cómo desde el momento que se entrega al sector financiero la promoción de la vivienda, comienza a desvanecerse la teoría de bienestar en la construcción de ciudad, para ser sustituida por una teoría light, de corte neoliberal. Las consecuencias de este cambio de rumbo implican drásticas variaciones en la morfología de Medellín, que en la primera mitad del siglo XX apostó por la configuración de barrios abiertos. Estos facilitan la localización de varios usos, incluso diferentes a la vivienda, actividades que animan el entorno urbano, promueven la vecindad, e incluso modelos de autogestión en relación a la seguridad urbana.

Los barrios obreros y de clase media que albergan a las familias de los empleados de fábricas, almacenes y oficinas, comienzan a ser sustituidos por productos inmobiliarios, que entre varios aspectos promueven el reclutamiento de las familias, reduciendo al máximo el contacto con el otro, que en el contexto anterior es considerado vecino. Las morfologías que propone el sector inmobiliario se caracterizan en gran medida por su irregularidad y por conformar guetos cerrados, cuyo único vínculo con la ciudad es el control de acceso para quienes no son propietarios o residentes.

La política de construcción de los barrios obreros y de clase media, apoyada en una estética sobria, ha aglomerado una significativa población en áreas físicamente limitadas, donde la estructura del espacio urbano, por un mecanismo de transferencia disipa tanta energía concentrada, mediante la apropiación de parques y zonas verdes, acompañadas de actividades que facilitan la proximidad de los vecinos, es

\footnotetext{
${ }^{55}$ Según el Documento Técnico de Soporte del Plan de Ordenamiento Territorial de Medellín, en su última revisión (Acuerdo 046 de 2006), Medellín ofrece 4 metros cuadrados por habitante, y el mínimo aconsejado por la OMS es de 15 metros cuadrados por habitante.
} 
decir, permite a los actores urbanos la construcción de itinerarios con sentido, recrea escenarios para ejercitar el simulacro de una memoria colectiva, sometida a los estereotipos estetizantes del paisajismo de consumo.

Los proyectos inmobiliarios contemporáneos ahora promueven una estética del marketing, un nuevo paisajismo sin un proyecto político y sin una propuesta hacia lo público, ya que los espacios y el tiempo para la disipación urbana son planteados, como un recurso individual. Para el mercado inmobiliario la construcción de anamnesis (estructuras de memoria) sale costosa, por lo que produce estructuras urbanas donde predomina la amnesia. La composición de estas propuestas, en cuanto a la disposición y distribución de los componentes semióticos, ya no le interesa; no es importante entonces suscitar enlaces de comunicación entre los ciudadanos sino, al contrario, construir espacios para la insensibilidad hacia el otro.

Esta transformación es especialmente evidente en los tipos de borde plegado alongado y borde sedimentado saturado. En el primer caso, como pudimos observar en apartados anteriores, se trata de los proyectos de expansión sobre las laderas que configuran la periferia de Medellín. Los proyectos en ejecución desde los últimos seis años vienen proponiendo la implantación de torres de vivienda, que agrupadas en polígonos irregulares y cerrados, exigen la extensión de la infraestructura urbana, sobrepasando sectores residenciales ya consolidados y con muy bajas especificaciones urbanas (equipamientos, vías y espacio público).

En lo que se refiere al segundo caso, la saturación se debe precisamente al proceso de especulación urbana sobre sectores residenciales consolidados en su gran mayoría, varios de estos con adecuadas proporciones de compacidad, complejidad y axialidad urbana, que son perturbados por la intromisión de nuevos componentes que por su escala y configuración apretujan las relaciones de vecindad, al punto de volverlas insostenibles.

\section{- La imposición del elemento arquitectónico sobre el urbanismo. La escasez o la reducción de la narrativa en el paisaje}

El proyecto de ciudad burguesa definía claramente la disposición y distribución de los componentes arquitectónicos en el espacio urbano, entendiendo que estos hacen parte de un sistema que permite a los actores urbanos hacer lectura en sus trayectos, y ejercitar así, la memoria urbana. Las plazas de mercado, los bancos, los almacenes, las fábricas, las iglesias, las escuelas, los colegios y las universidades se localizaban de tal manera que los ciudadanos atribuyeran sentidos a sus itinerarios, ya que la modulación del espacio y del tiempo adquirían tal integración, que no era posible desligar ningún componente de la escenografía urbana.

La ciudad alcanza tamaños insospechados, y la generación de escenografías urbanas sobre las cuales discurren relatos paisajísticos con sentido y coherencia empieza a salirse del manejo a escala del ciudadano. La segregación urbana, ocurre cuando ya ha transcurrido la mitad del siglo XX. El mismo Estado desarrolla grandes proyectos urbanos, que enfatiza una producción en serie de vivienda, descuidando así el tejido que merece la construcción de ciudad. 
En los últimos años se formulan políticas y acciones que intentar cerrar las brechas de una ciudad con una significativa segregación. Sin embargo, la insistencia por resaltar y relucir imponentes objetos arquitectónicos reduce el espacio urbano a un tapete ceremonial que se extiende, subordinado ahora a una arquitectura que se impone sobre lo urbano. Y el paisaje, compuesto por esos itinerarios que entretejen relatos con sentido en la ciudad, se ha convertido en un mero ornamento.

La arquitectura contemporánea que se ha ido produciendo en Medellín crea un espacio predominantemente virtual de relación con el tiempo, donde los actores son tomados y reflejados en el espacio real con los códigos de las imágenes borrosas del cuerpo marketing, donde no se pueden diferenciar los cuerpos vivos de los cuerpos empaquetados en las imágenes. Esta arquitectura ha sido creada a partir de la imagen publicitaria, en los que a su vez la imaginación sólo propone un tiempo ruinoso.

Este tipo de transformación se aprecia especialmente en los bordes urbanos sobre los cuales se intentan desplegar superficies que refuercen los discursos ideológicos que pretenden estructurar la ciudad, más no lo urbano, así lo quisieran, pues es esto precisamente lo que se escapa a sus dominios. Los bordes urbanos plegados conglomerados, aglutinantes, integrados y jerarquizados son los escenarios donde se vienen concentrando este tipo de acciones, en los que se desea mostrar una ciudad perfecta, y no una ciudad cargada de realidad, por insoportable que esta sea.

\section{- La caricatura patrimonial o la política de convertir lo viejo en adorno o en ruina}

La narrativa del paisaje se soporta sobre itinerarios que facilitan a los actores urbanos recrear cotidianamente estructuras de memoria, que dan sentido a sus trayectos. Con la transformación de la ciudad es inevitable que algunos componentes semióticos sean sustituidos por otros y que se anexen superficies discursivas y que se produzcan nuevos relatos urbanos. El borde urbano es muestra de algunos de estos desplazamientos en la narrativa del paisaje, en donde lo viejo y lo nuevo interactúan en distintos modos, para modificar a tono con la cultura, los relatos y sus itinerarios, que reproducen los actores urbanos en sus trayectos cotidianos.

Cuando la transformación del paisaje en su proceso da lugar a las transiciones requeridas para que lo nuevo y lo viejo construyan relatos que comunican el pasado con el presente, la ciudad se recrea como un palimpsesto urbano. Cuando esta fuerza de diálogo del tiempo cultural, no ocurre y es suplantada por tratamientos de conservación superficial (mantenimiento de fachadas), entonces se impone una caricaturización en la narrativa del paisaje.

Lo patrimonial, por lo menos en lo que atañe a la narrativa del paisaje, no se reduce a la contemplación de tipologías arquitectónicas, representativas de un momento de la historia de la ciudad. El patrimonio es también, y con mayor interés, aquellos elementos que sostienen escenografías, en este caso urbanas, en donde pueden desarrollarse actividades culturales, sociales, económicas y políticas de especial valor para la identidad de la ciudad. Pero cuando el patrimonio se reduce a lo primero, las acciones que se ejercen para transformar el paisaje no son más que una mueca que desestabiliza las estructuras de memoria que deben nutrir la narrativa del paisaje. 
Una política de lo patrimonial no debe basarse en la congelación de escenarios con las actividades urbanas que en determinado momento animan los itinerarios que siguen los actores. El patrimonio debe ser asumido como parte de una transformación gestionada del paisaje, en donde el cambio que se produzca, como acción natural de la cultura, se retroalimente de las estructuras de memoria que conforman los componentes que han construido la experiencia paisajística.

Hasta el momento, tanto en algunos bordes urbanos plegados (conglomerado, integrado, aglutinante y jerarquizado, especialmente), como en algunos bordes urbanos sedimentados (desperdigado y amontonado, con mayores repercusiones), han mantenido componentes patrimoniales desde su estructura física, completa o parcialmente. Sin embargo, por el énfasis con los que han sido tratados, sólo consiguen restaurar memorias erráticas, pues los actores urbanos en sus itinerarios no logran incorporarlas de forma dinámica en sus trayectorias, pues algunas de las actividades que acompañaban estos objetos fueron erradicadas, sin explorar su convivencia con los objetos que recientemente se han introducido sobre estos escenarios.

\section{- La imposición de unas mínimas rutinas, o modulaciones del tiempo, ante la diversa proliferación de itinerarios que producen los distintos actores urbanos}

La planificación de las ciudades, como es el caso de Medellín, ha tenido un marcado énfasis espacial, y esto se aprecia en la estructuración normativa de los instrumentos de regulación. Basta con reconocer la proliferación de conceptos de tipo administrativo y funcional en que se divide por porciones a la ciudad: zona, comuna, barrio, sector, etc. Esta situación igual se presenta en las consideraciones de la composición arquitectónica y urbana, en las que predominan las dimensiones espaciales, y en las que poco se hace consciente las implicaciones que las propuestas de intervención tienen sobre el manejo del tiempo, y que afecta a todos y cada uno de los actores que hacen parte de las escenas diarias de la ciudad.

El tiempo, aunque no tiene expresiones alusivas explícitas en los instrumentos de planificación urbana y en los criterios de diseño arquitectónico y urbano, es curiosamente la dimensión que garantiza las vivencias de los sujetos, quienes son los que construyen la experiencia paisajista. Del tiempo y su concepción dominante en la ciudad podemos aludir la marcada herencia de la revolución industrial, que bajo las prerrogativas de le eficiencia y la eficacia en la producción, determinó las áreas de ocupación a partir de la especialización del uso (residir, trabajar, transitar, recrearse), zonas a las que se acude o accede en momentos independientes, según los horarios establecidos para cada uno de los sectores de la sociedad.

La insistencia en transformar todos y cada uno de los fragmentos de ciudad bajo nociones de sincronización de las actividades urbanas y la reducción de las posibilidades de acceso en el tiempo a las mismas, viene excluyendo la participación activa y continua de algunos sectores de la sociedad, especialmente mujeres, niños y ancianos. Al restringir los horarios de los servicios que ofrece la ciudad, sin considerar las diversas modalidades temporales que favorecen a los distintos actores, el escenario urbano en general sólo es sujeto de protagonismo de un reducido espectro actoral, y el foco de atención de algunos lugares, se comprime a un escaso margen temporal, ante la denodada especialización de la actividad. 
Por otro lado, estamos presenciando procesos de transformación del paisaje urbano en los que se está perdiendo información que permite a los actores hacer lectura del sentido y las trayectorias de cambio, situación que si previera facilitaría un balance en la renovación (Lynch, 1975). Es claro que la ciudad muestra estados estacionarios que fluctúan entre diferentes configuraciones, sin embargo, una gestión del proceso de transformación del paisaje debe velar por entornos urbanos que permitan la ilación de las marcas de lugar por parte del lector urbano, y también considerar su eliminación cuando en definitiva no haga parte ya del armazón temporal. ${ }^{56}$

\subsection{Líneas de acción a considerar en una gestión para la transformación del paisaje}

Asistimos a procesos de transformación del paisaje contemporáneo, tal y como lo plantea Pablo Arias (2003), dominados por la rapidez, la ignorancia y la insensibilidad ciudadana. El mosaico de imágenes de la transformación del paisaje urbano de Medellín nos muestra que para fundar las bases para una gestión del cambio, de tal manera que se logre la práctica de una política de la justa memoria (Ricoeur, 2008), se requiere de unas líneas de acción que orienten las estrategias que luchen contra el olvido y con los excesos de la memoria.

No podemos continuar impávidos frente a una transformación del paisaje que viene rompiendo los enlaces de comunicación y reconocimiento entre ciudadanos que representan diversas culturas dentro de la misma ciudad. Los gestores del paisaje deben asumir el reto de una producción del espacio y del tiempo, a partir de la elaboración de los hechos que registra la percepción de las diferentes miradas o puntos de vista (Silva, 1994), que al sobreponerse entre sí, recrean eso tan dinámico y turbulento que es lo urbano.

Es necesario devolver una imagen a la ciudad provista por los relatos de la memoria que han construido el mundo de lo urbano, y que configuran diferentes estratos narrativos del paisaje. Todo esto porque el paisaje está perdiendo espontaneidad y viveza (Arias, 2003) por lo que se requiere, entre varias acciones por ejemplo, descubrir y elaborar nuevos argumentos narrativos y compositivos, que articulen la estructura funcional de la ciudad con las estructuras de la memoria de los actores urbanos. Esto debe ser conseguido de tal manera que no predominen unos pocos discursos ideológicos sobre el gran conjunto de historias que insisten por ocupar un espacio y recrearse en el tiempo de la ciudad.

\section{- Refacturar la forma urbana a partir del reciclaje de las imágenes que ofrecen los estratos narrativos del paisaje urbano}

El inventario de imágenes de la ciudad, desde un enfoque no sólo histórico sino también crítico y estético, debe asumirse como una caja de herramientas que facilite la producción de nuevos esquemas

\footnotetext{
56 “ “(...) sería conveniente que el paisaje mostrase la impronta de hechos humanos y apareciese conectado con las personas vivas, estas improntas y conexiones deberían desdibujarse con el paso del tiempo y ser olvidadas, del mismo modo que se desvanecen y olvidan los recuerdos y las generaciones" (Lynch, 1975:74)
} 
que recuperen la práctica de la memoria. Es necesario re-componer algunos sectores de la ciudad que permitan a muchos exiliados urbanos recrear los escenarios que dan sentido a sus trayectos, partiendo de la re-invención, pues no se trata de volver a épocas pasadas sino de reorganizar estructuras narrativas para actores urbanos que merecen tener su espacio y tiempo en la ciudad.

La refacturación de este tipo de superficies discursivas en una probable reorganización de una imagen presente, tiene cómo alimentarse de los imaginarios que nos deja el repertorio de objetos y relaciones semánticas que conforman la historia urbana de la ciudad. Pero también, puede apelar a la imaginación de estos actores urbanos, que a pesar del exilio, aún se proyectan en el futuro de la ciudad.

\section{- Descubrir y elaborar nuevos argumentos narrativos y compositivos para un paisaje más diverso}

Es necesario explorar en la re-invención del paisaje urbano, de tal manera que se incluyan todos aquellos relatos que han construido lo urbano. Para tal efecto es necesario, además de emplear el eje, la axialidad y la simetría, argumentos compositivos que han dominado la configuración del paisaje, incorporando otras formas que permitan la articulación y modulación de argumentos narrativos que se caracterizan por tener dinámicas de mayor intensidad y movimiento.

La transformación del paisaje urbano ha sido en gran parte provocada porque con el transcurso del tiempo en la ciudad se han desarrollado distintas formas de mirar, de mostrarse y de desplazarse. Las políticas de ordenación del espacio público manifiestan una obsesión por el control de la disposición y distribución de los objetos en el espacio urbano, bajo esquemas cerrados que intentan a la fuerza que cada cosa permanezca en su sitio, según lo dicta el planteamiento ideológico de mayor poder.

Elaborar nuevos argumentos compositivos para la modulación intencionada del espacio y del tiempo en la ciudad exige el reconocimiento de las diferentes marchas, ritmos e itinerarios que los diversos grupos sociales, culturales, económicos y políticos entretejen sobre el espacio urbano. Es necesario entonces el estudio de los diferentes recorridos que trazan los diversos actores urbanos, identificando las actividades que sostienen sus dinámicas.

\section{- Recuperar el papel articulador de la arquitectura en la ciudad}

La arquitectura en la ciudad de Medellín, con su enfoque predominante en las actuaciones lideradas en el sector público y privado inmobiliario, ha puesto en superficie una ciudad fragmentada desarticulada de un paisaje interactivo y protagónico. La arquitectura producida no crea relaciones sintácticas que permitan a los actores realizar ajustes a las estructuras físicas, en los casos en que estas no se acomoden a las expectativas, o a los mismos cambios que surgen en la cultura.

La disposición y distribución de la nueva arquitectura que se produce en la ciudad, promovida tanto por el sector privado como por el público, se efectúa bajo esquemas de organización totalmente 
cerradas, que por la magnitud de las intervenciones no sólo tienen dificultades para ajustarse a las modificaciones que exige el cambio, sino que requerirá la inversión de altos costos (energía) para su sostenimiento.

La arquitectura, por lo tanto, debe recuperar su papel articulador en la ciudad, conformando estructuras sintácticas que permitan la producción de la morfogénesis. Es decir, la producción de componentes semánticos que contribuyan al mantenimiento de estructuras de memoria, pero que a la vez, faciliten el intercambio con otros componentes o que se ajusten a las exigencias de la transformación del paisaje.

\section{- Revitalizar la relación naturaleza-ciudad, revisando las representaciones y las prácticas} de ésta en los diferentes escenarios urbanos

Presenciamos en la transformación del paisaje urbano de Medellín, una reducción muy significativa de la presencia de la naturaleza en la configuración de los escenarios urbanos. Y en los espacios que aún aparecen como un componente considerado, apreciamos cómo su tratamiento es meramente ornamental.

Esta reducción de la naturaleza en la ciudad es uno de los aspectos que más contribuye a la crisis que apreciamos en la narrativa del paisaje contemporáneo, por lo tanto, uno de los aspectos que requiere una mayor atención en una gestión del paisaje urbano. La presencia de la naturaleza de la ciudad, además de los atributos que la ecología urbana le atribuye objetivamente, también merece destacarse por el valor subjetivo y cultural, que proporciona en los relatos urbanos y que son construidos por los actores urbanos en sus trayectorias cotidianas.

La naturaleza, en el proceso de transformación del paisaje urbano, se ha convertido en otro componente artificial más del medio construido, perdiendo así su labor representacional, y es tratada como una intrusa debido a un imaginario del progreso que ha relacionado la naturaleza con el atraso. Pero a su vez, nos resistimos a erradicar por completo la naturaleza de la ciudad, ya que esta representa el vínculo que tenemos con nuestros orígenes, incluso con nuestras creencias y mitos, soportes de la cultura que recreamos continuamente.

En una gestión del paisaje contemporáneo se requiere la revitalización de la relación naturaleza-ciudad, reconociendo en primera medida las distintas formas que esta asume en las prácticas sociales y culturales. Por ejemplo, son muy diferentes las representaciones que de la naturaleza sostienen los inmigrantes campesinos en la ciudad, quienes en buena medida se localizan en las áreas periurbanas, a las que manifiestan aquellos sectores sociales cuyo vínculo con el campo se reduce a unos encuentros esporádicos, o mediados por los medios de comunicación.

Revitalizar la relación naturaleza-ciudad debe superar entonces aquellas intervenciones controladas en los parques, jardines y zonas verdes, pues actuaciones discretas no alcanzan por sí mismas a representar los múltiples vínculos que una sociedad tan diversa establece con la naturaleza. Es más, la transformación misma del paisaje urbano, revisada desde un enfoque crítico, debe superar esa mirada reduccionista de la naturaleza asociada sólo a la presencia de vida vegetal. Qué más natural que los procesos que se han venido evidenciando en los problemas ambientales como las dificultades con el 
manejo de residuos, el ruido, la saturación visual, entre otros, indicadores todos de cómo el hombre requiere de un hábitat que facilite su desarrollo y comunicación con el medio y con los otros.

\section{- Por una política del tiempo que promueva el discurrir de las diferentes trayectorias que trazan los distintos sujetos del paisaje.}

Una política pública privilegia la construcción de un paisaje pluralista, configurado como espacio flexible, conjugado con las diferentes trayectorias o guiones de sentido que cada actor en particular desee trazar como discurso de autodeterminación. Una gestión del paisaje urbano provee motivos a los actores de la ciudad para escapar de esquemas temporales cerrados y rígidos, de tal manera que programen sus trayectos más allá del tiempo objetivo, impuesto incesantemente por los enfoques de la eficiencia productiva (la ciudad máquina de la modernidad), y sean por lo menos en algunos escenarios neutrales, gobernados por el tiempo subjetivo de cada grupo social o situación que en particular se suscite en la ciudad.

Otorgar la posibilidad a los actores urbanos, según los diferentes intereses que los agrupen, de controlar algunas variables que les permita prolongar o acortar la duración de sus experiencias, es quizás uno de los mecanismos aún muy poco explorados en la gestión del paisaje. El paisaje como síntesis de una experiencia sensorial, puede ser manipulado a través del manejo de algunas claves, naturales y artificiales, que incidan tanto en el ritmo como en la duración de los acontecimientos. La luz, los sonidos, los olores, entre otras variables sensoriales, transmiten información a los actores urbanos, que según sus propósitos interpretan como indicaciones para su aparición o salida de la escena pública.

Tal propósito exige que la forma del espacio pueda adoptar cambios, que permitan la ordenación de diferentes trayectos y secuencias, en tal sentido que se ajusten y adapten a las representaciones culturales de los grupos sociales que frecuentan los lugares de la ciudad por diversas razones. Esto a su vez, permite que los actores urbanos tengan diferentes opciones de elección, tanto de los acontecimientos a los que deseen sumarse, como al ritmo y a la duración que a estos prefieran darle en cada ocasión. No se trata de renunciar por completo a estructuras temporales estables, y a la coordinación de algunas actividades que sostienen el funcionamiento de la ciudad, pero de lo que si se trata, es de ampliar las opciones de programación, que dependiendo de las circunstancias y los actores involucrados, unas funciones predominen más sobre otras, sin que esto implique una perfecta sincronización, a tal punto que ate los actos espontáneos y fluctuantes que caracterizan a lo urbano.

Los bordes urbanos son una franja dentro del sistema territorial de la ciudad que podría albergar este tipo de innovaciones en la programación de actividades e itinerarios. Y es en este otro punto donde una disciplina fundante de la gestión de la transformación del paisaje debe aplicar criterios de construcción de procesos, más que el diseño de objetos, que empleando el potencial tecnológico disponible, logre el despliegue de una multiplicidad de capas, en las que sea posible la lectura simultánea de diversos discursos narrativos del paisaje. 


\section{ANEXOS}

Mapa 1. Plano topográfico de Medellín, 1875

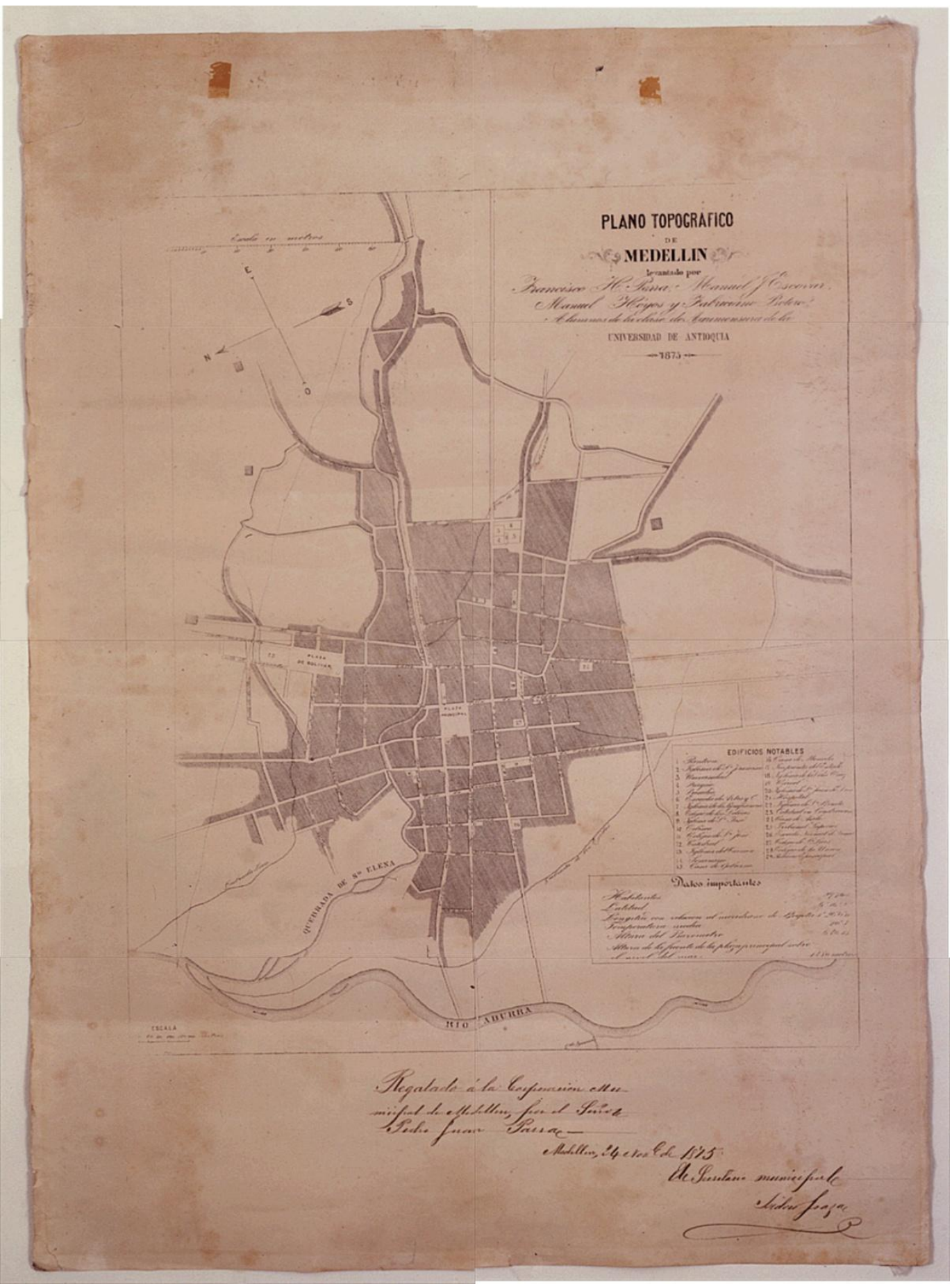

Fuente: Jaramillo y Perfetti (1993) 
Mapa 2. Plano topográfico de Medellín, 1906

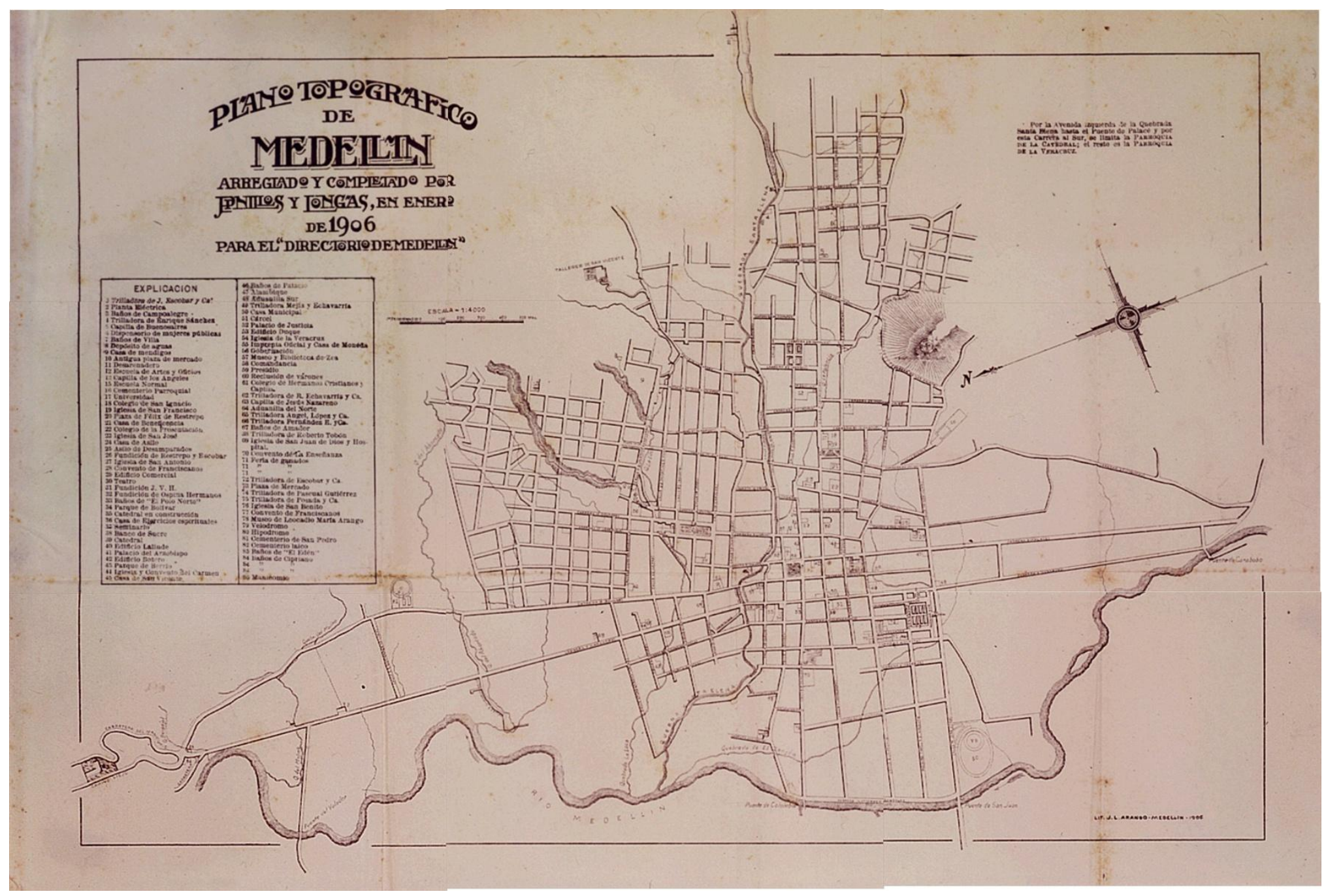

Fuente: Jaramillo y Perfetti (1993) 
Mapa 3. Plano de la ciudad de Medellín, 1908

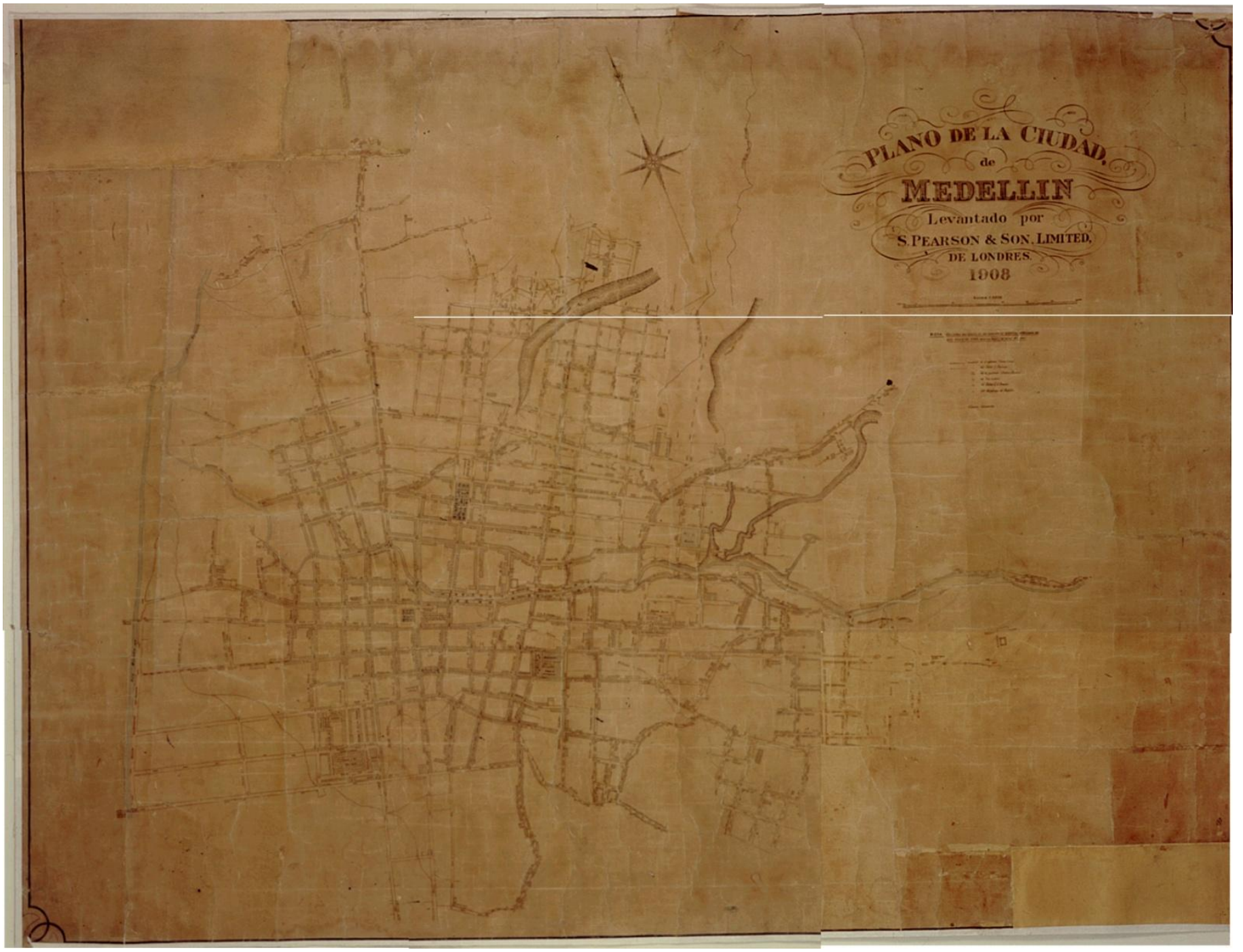

Fuente: Jaramillo y Perfetti (1993) 
Mapa 4. Croquis del distrito de Medellín, 1929

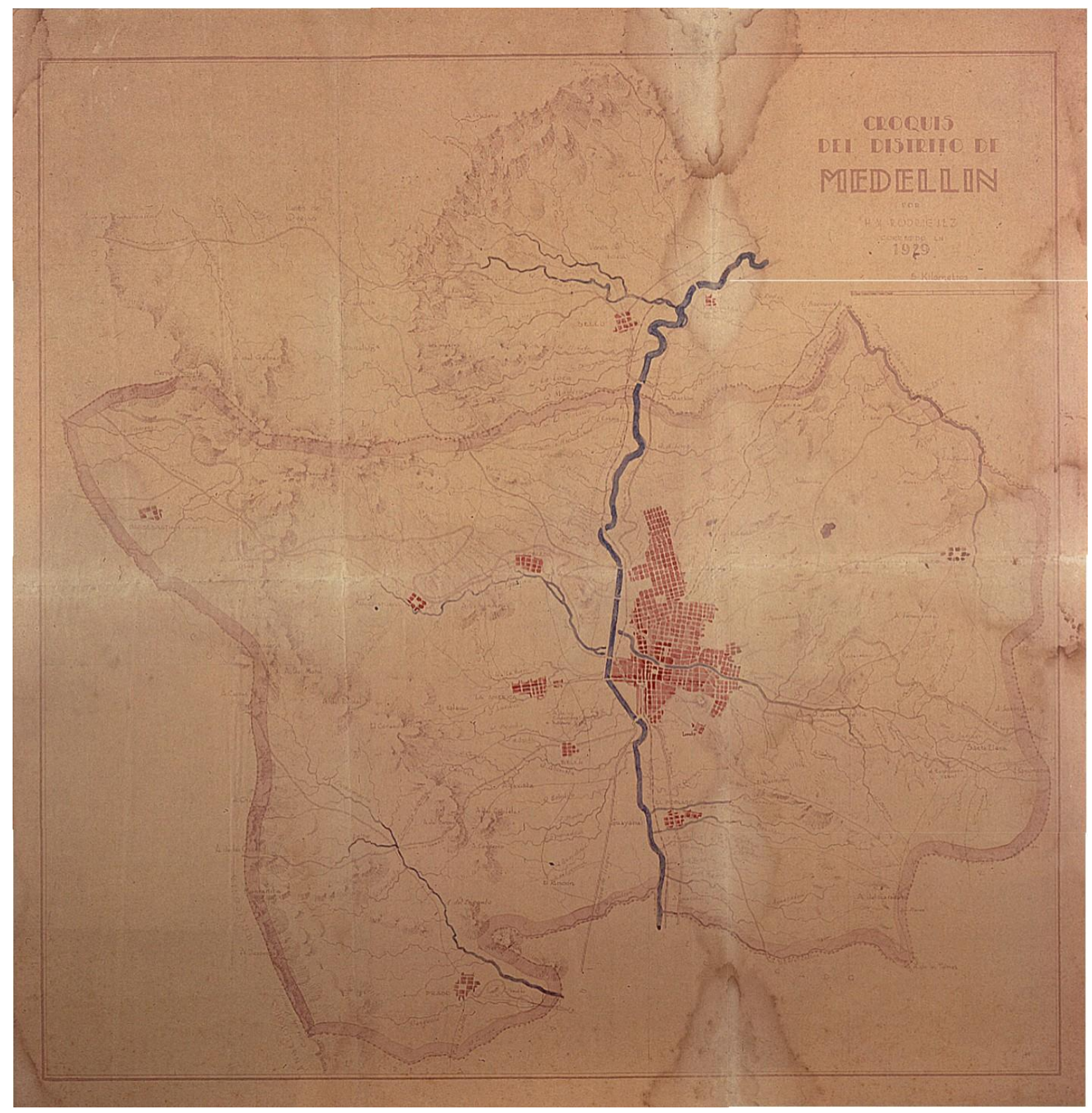

Fuente: Jaramillo y Perfetti (1993) 
Mapa 5. Plano general de Medellín, 1938

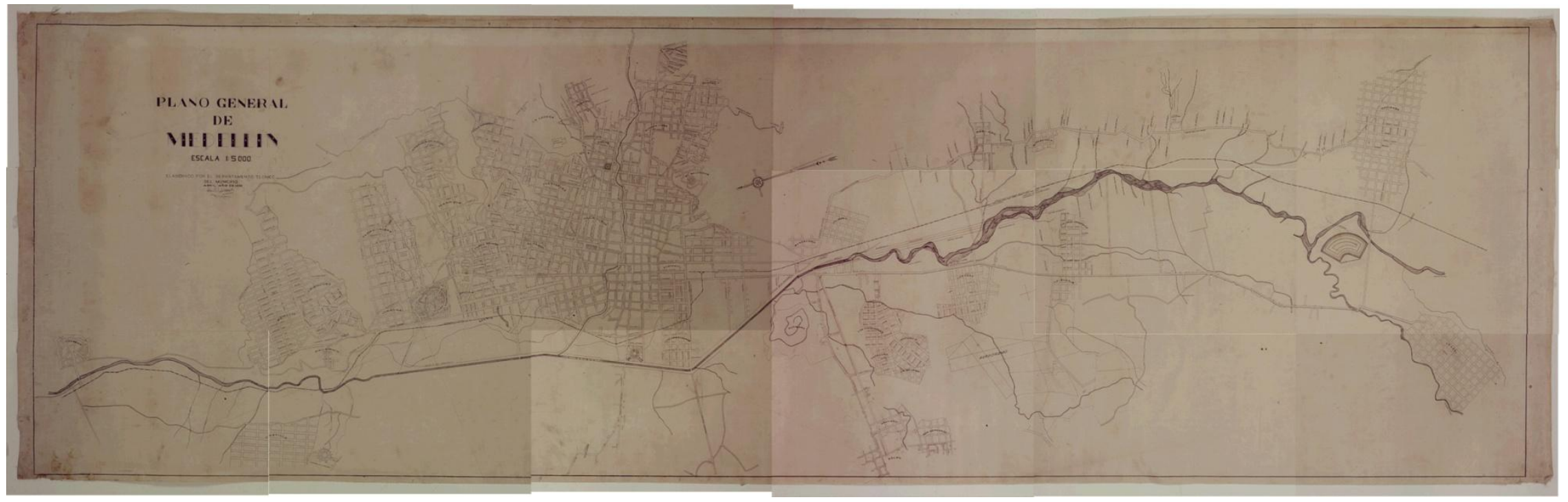

Fuente: Jaramillo y Perfetti (1993) 
Mapa 6. Plano de Medellín, 1944

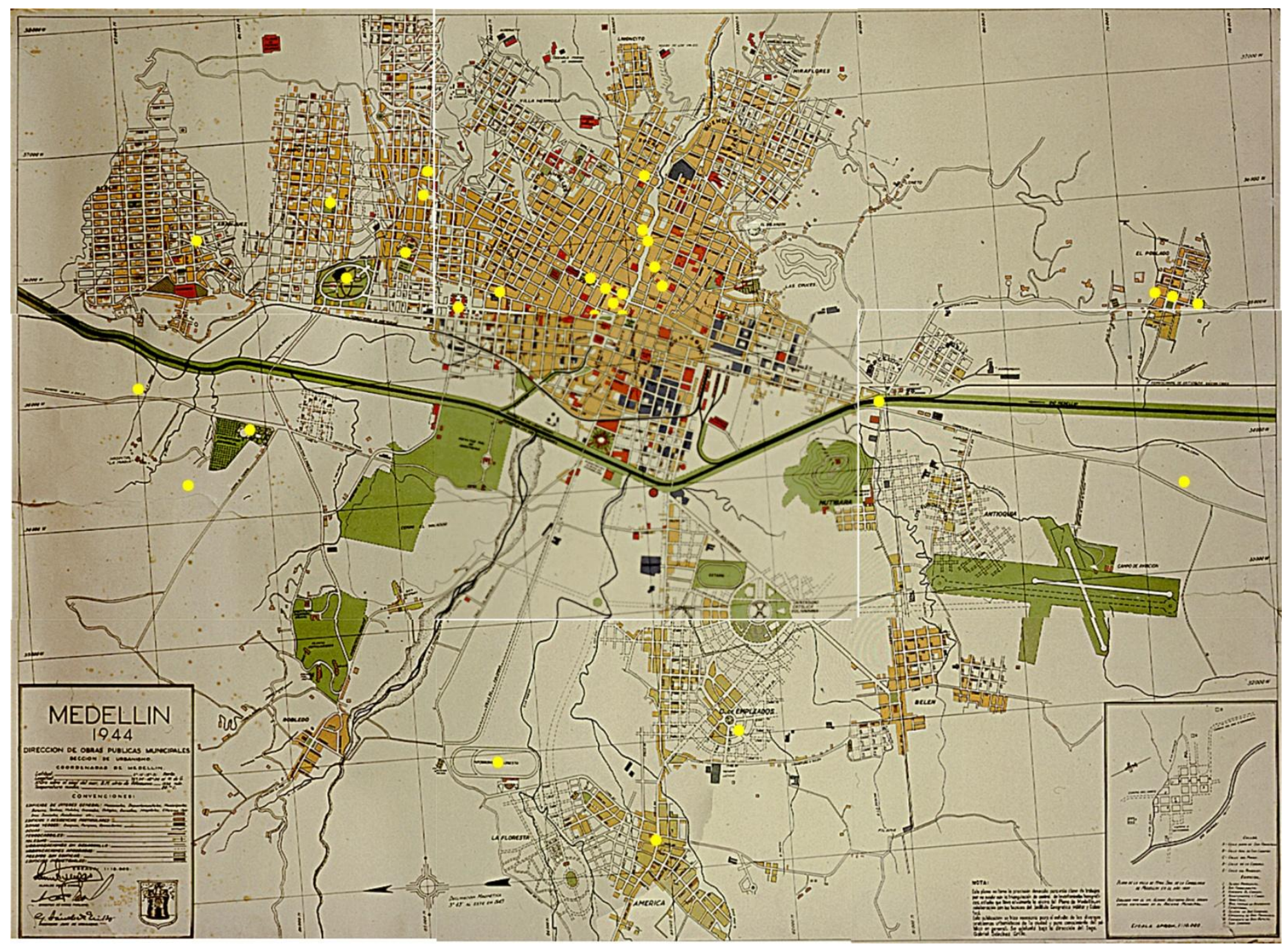

Fuente: Jaramillo y Perfetti (1993) 
Mapa 7. Plano de "Medellín Futuro", 1913

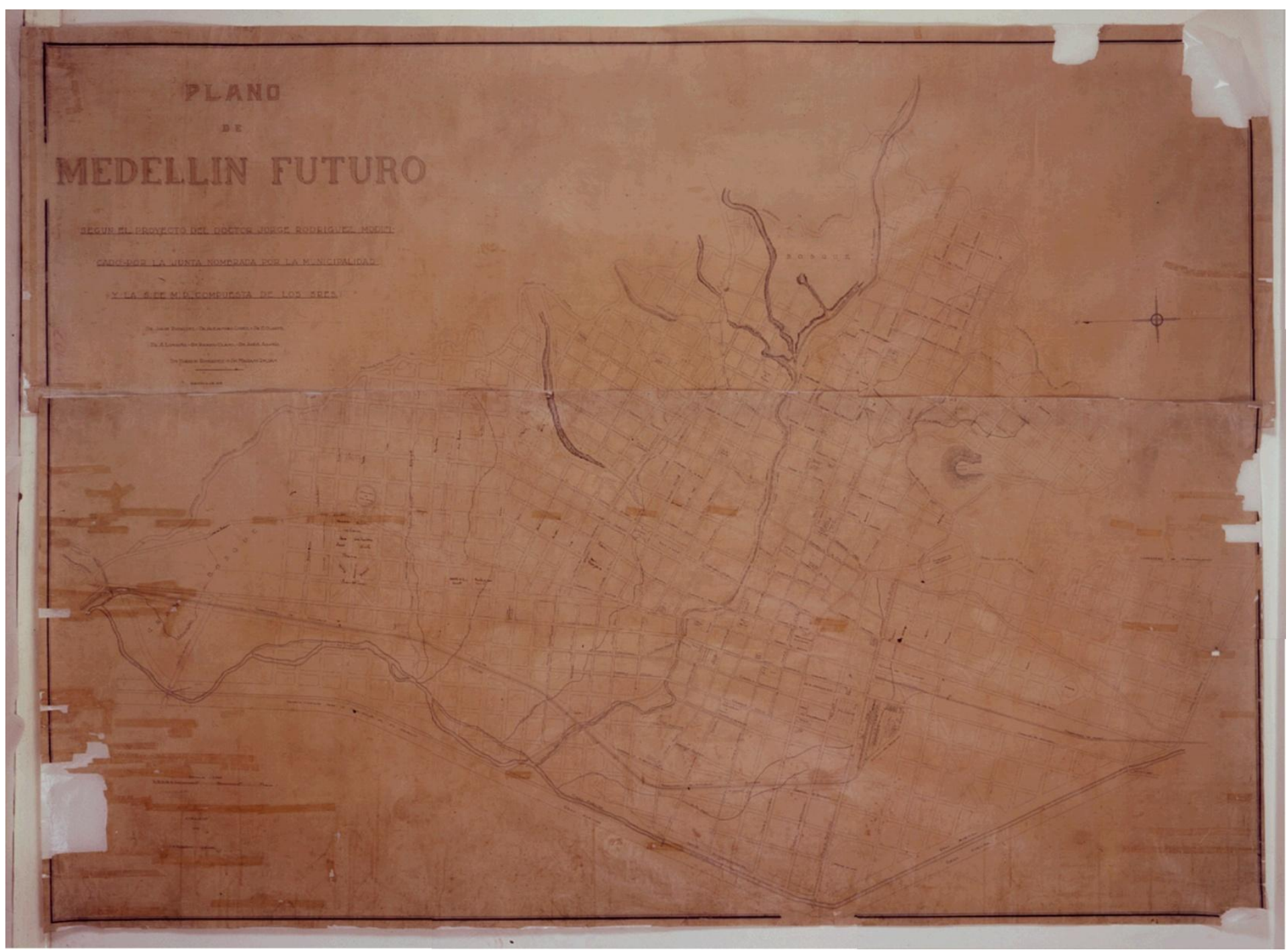

Fuente: Jaramillo y Perfetti (1993) 
Mapa 8. Plano zonificación del Plan Piloto, 1948

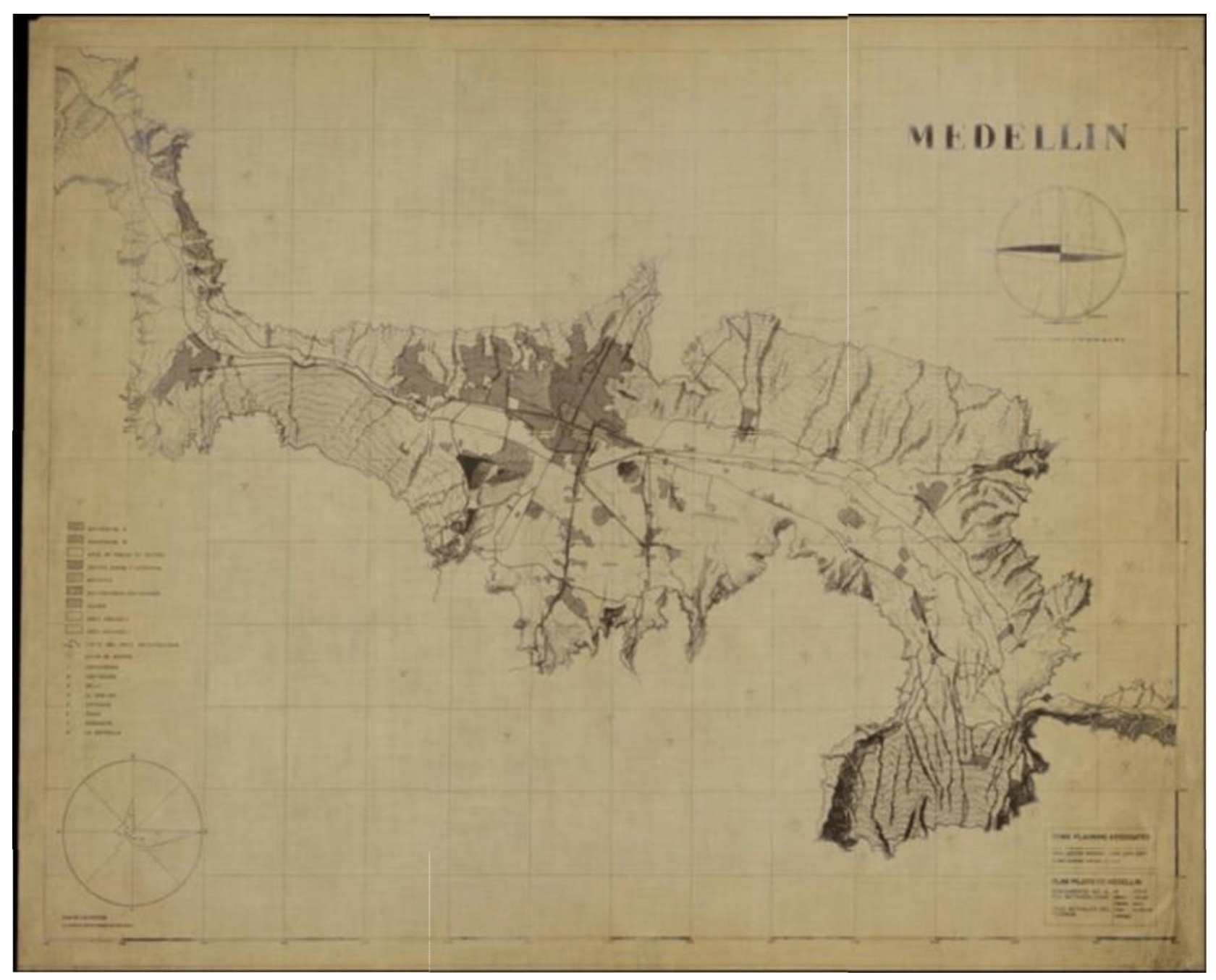

Fuente: tomado de Archivo Histórico de Medellín, disponible en:

http://ahmedellin.janium.net/janium-bin/sumario.pl?Id=20120430213235 
Mapa 9. Estudio de la forma urbana de Medellín, 1948

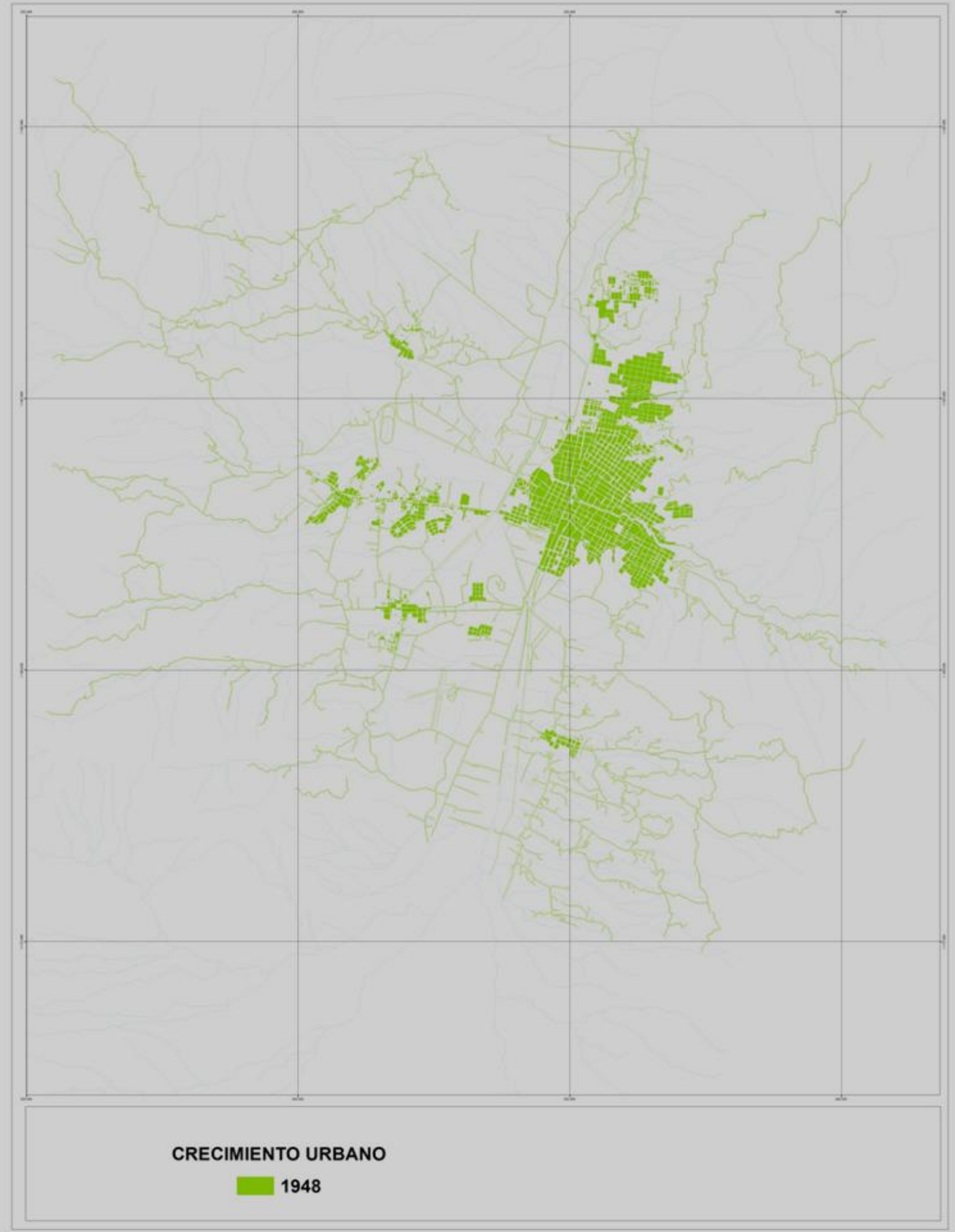

Fuente: Plano elaborado por el autor con base en el estudio del Área Metropolitana del Valle de Aburrá y Universidad Pontificia Bolivariana (2007). 
Mapa 10. Estudio de la forma urbana de Medellín, 1970

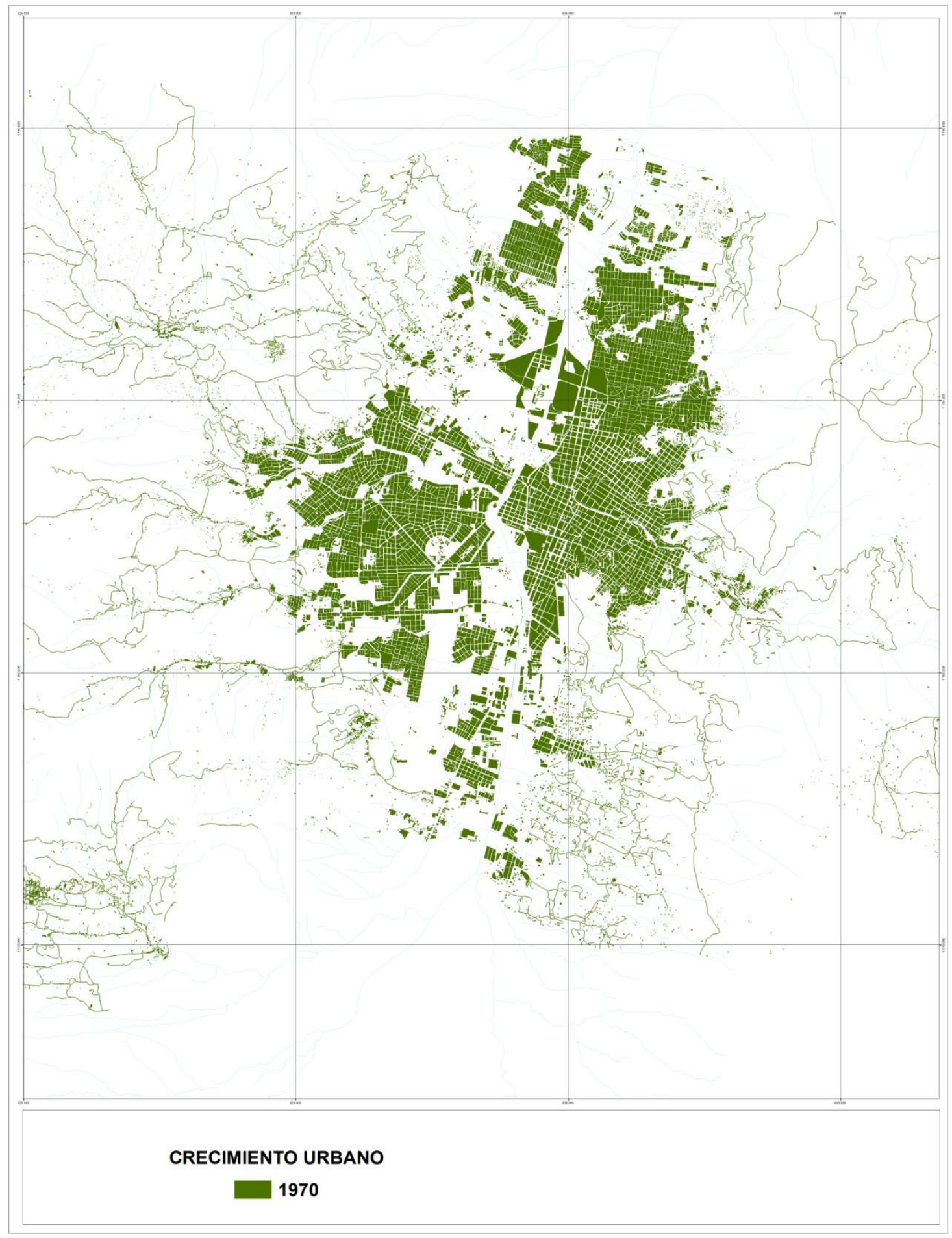

Fuente: Plano elaborado por el autor con base en el estudio del Área Metropolitana del Valle de Aburrá y Universidad Pontificia Bolivariana (2007). 
Mapa 11. Estudio de la forma urbana de Medellín, 1985

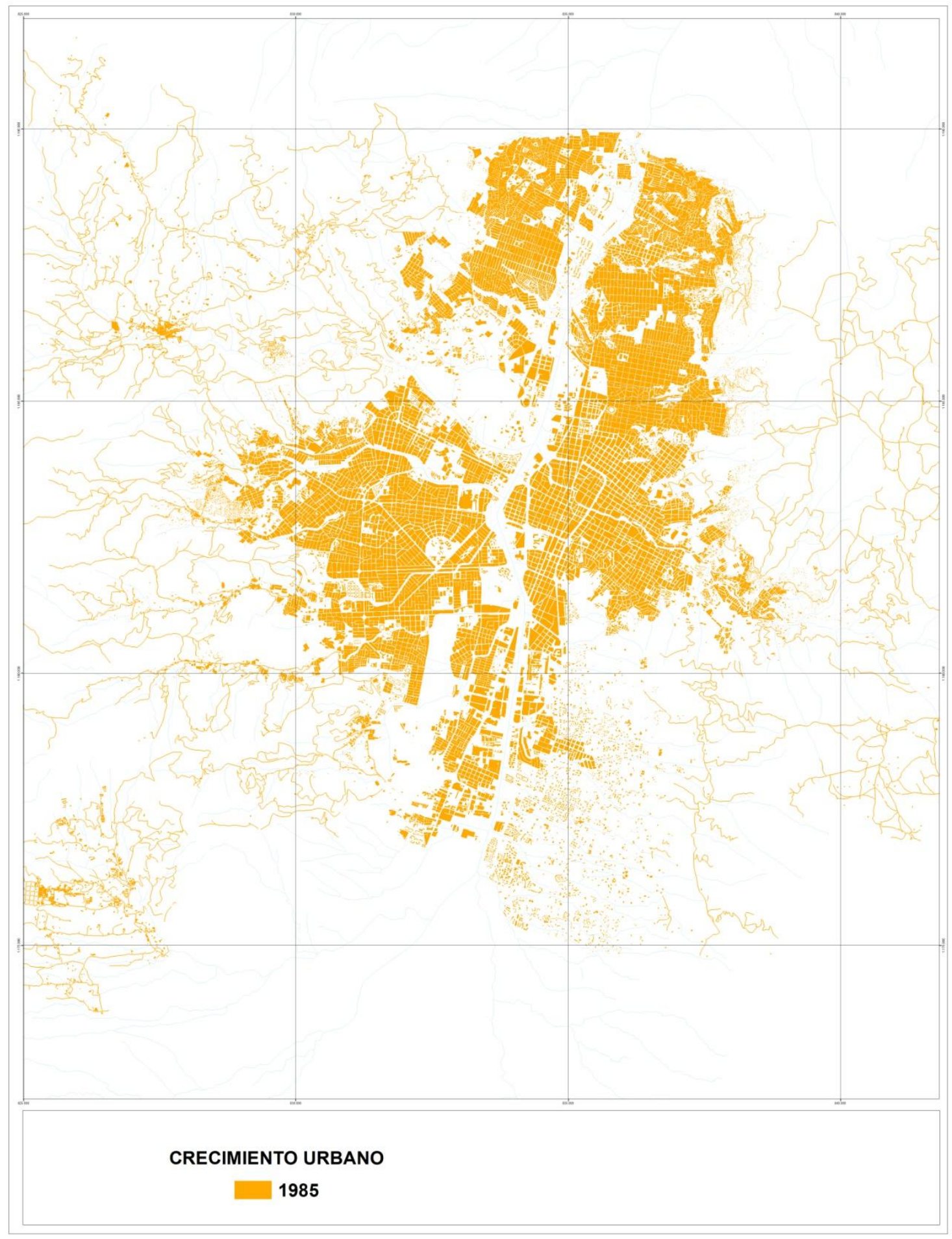

Fuente: Plano elaborado por el autor con base en el estudio del Área Metropolitana del Valle de Aburrá y Universidad Pontificia Bolivariana (2007). 
Mapa 12. Estudio de la forma urbana de Medellín, 1996

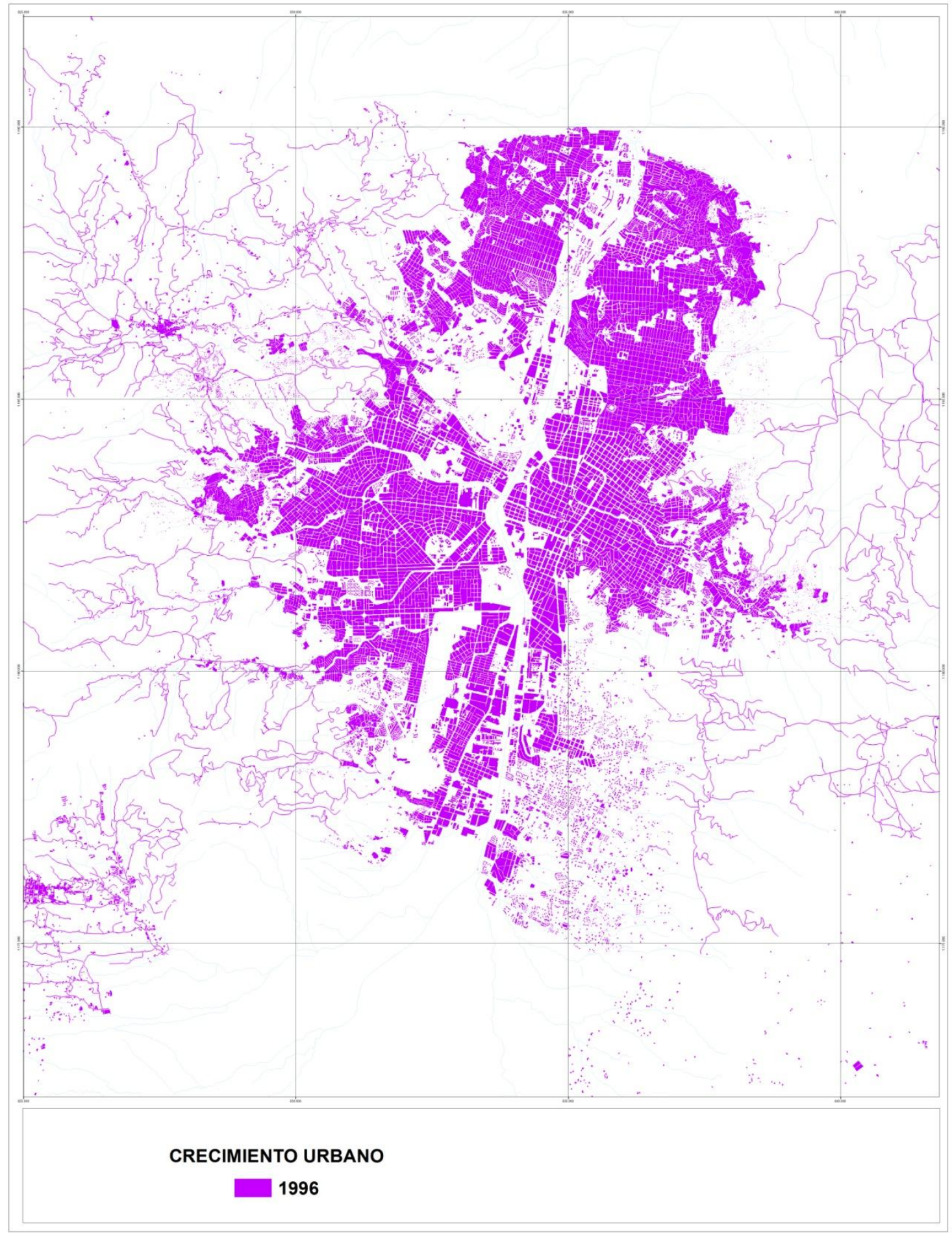

Fuente: Plano elaborado por el autor con base en el estudio del Área Metropolitana del Valle de Aburrá y Universidad Pontificia Bolivariana (2007). 
Mapa 13. Estudio de la forma urbana de Medellín, 2010

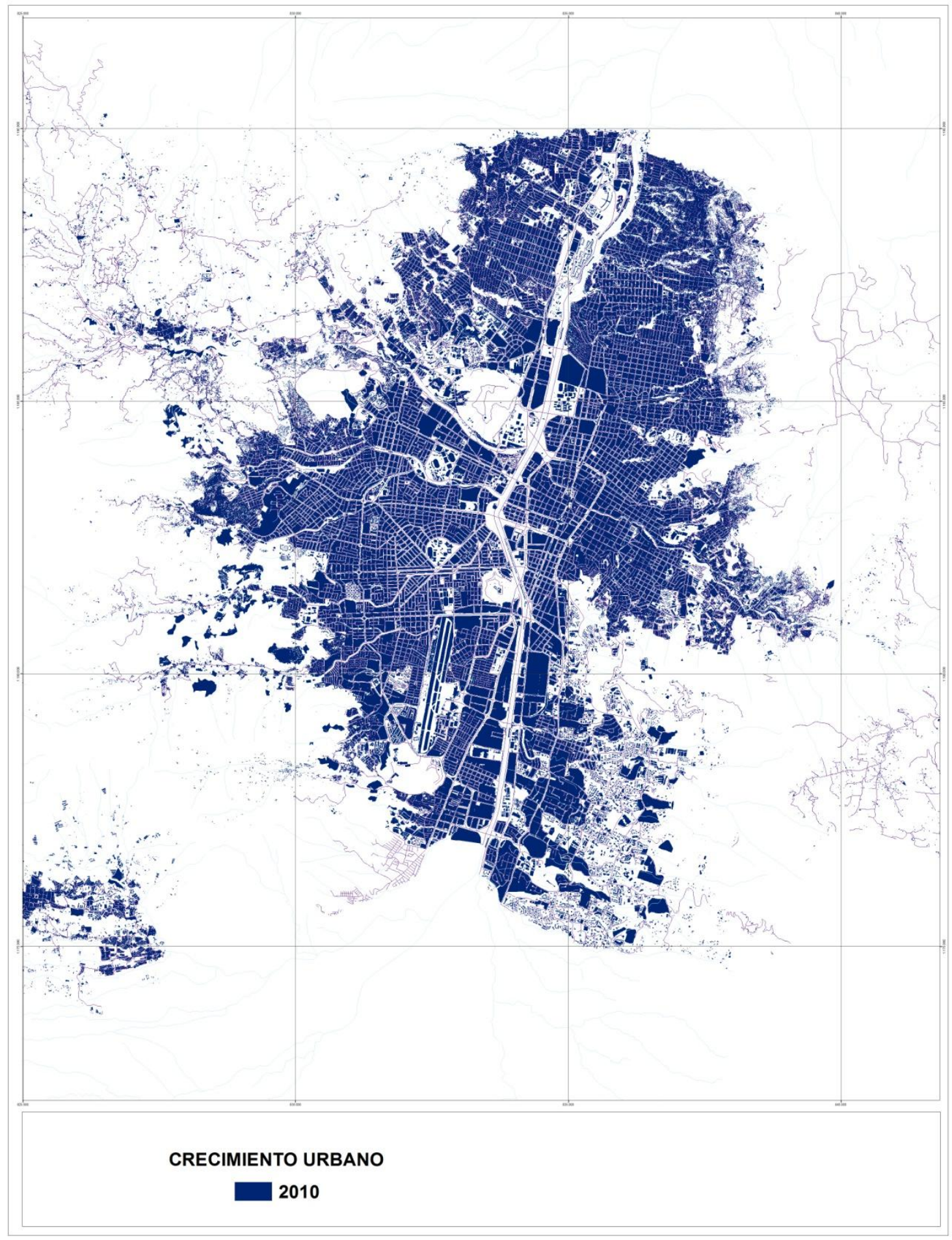

Fuente: SIGAME (2010) 
Ilustración 47. Registro fotográfico del recorrido por el paisaje urbano contemporáneo de Medellín a través de los estratos narrativos de 1870 a 1925

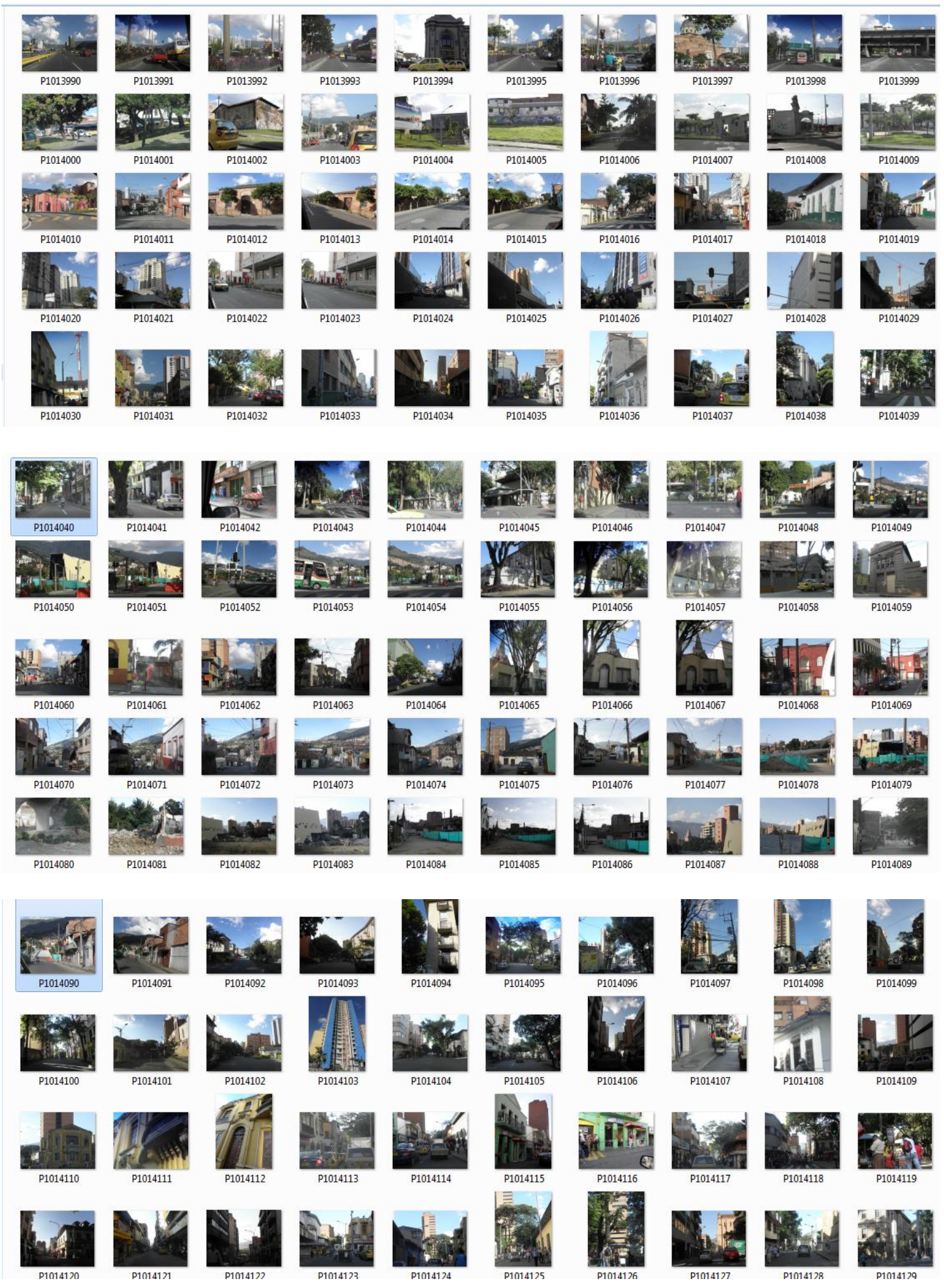




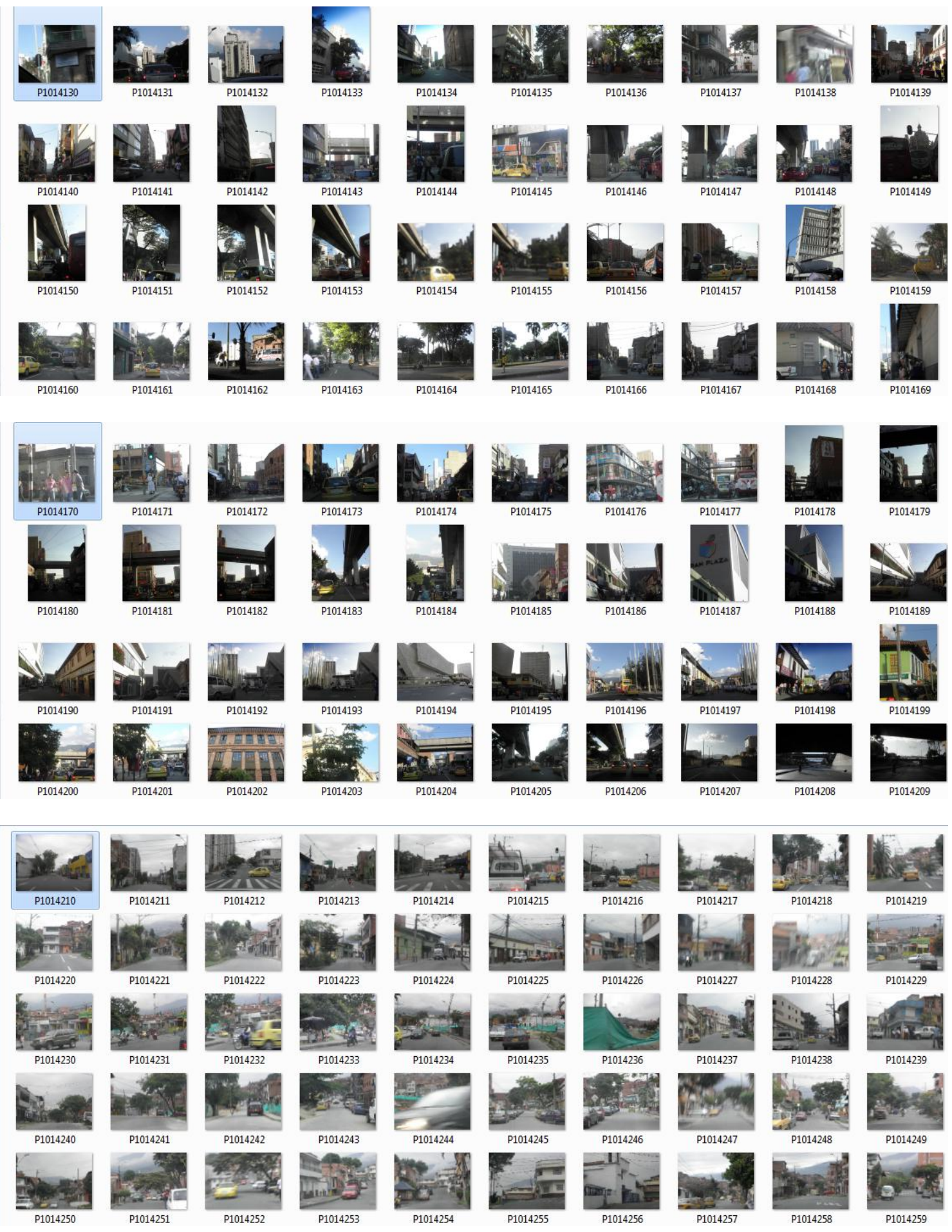




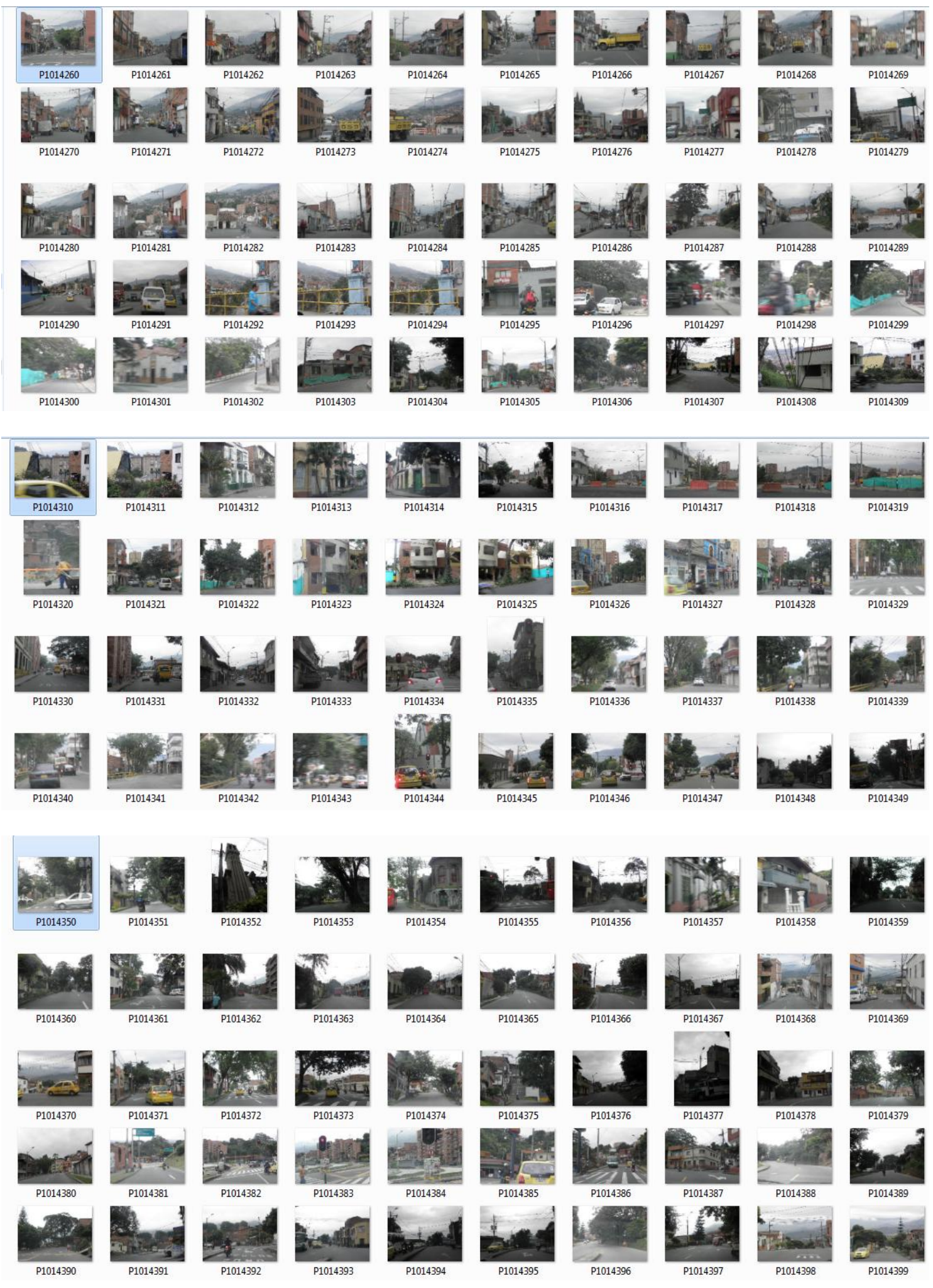


Ilustración 48. Registro fotográfico del recorrido por el paisaje urbano contemporáneo de Medellín a través de los estratos narrativos de 1925 a 1970

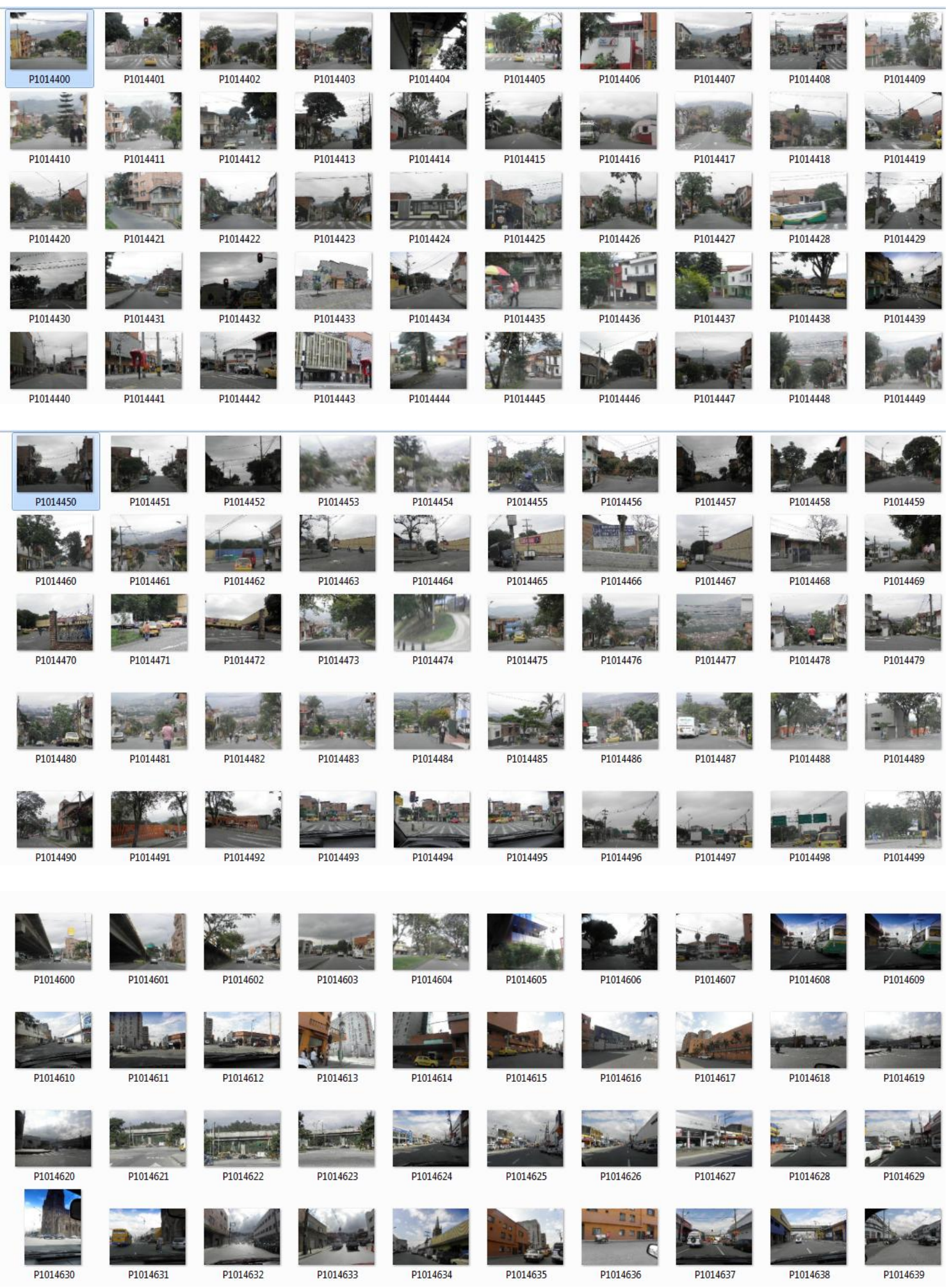




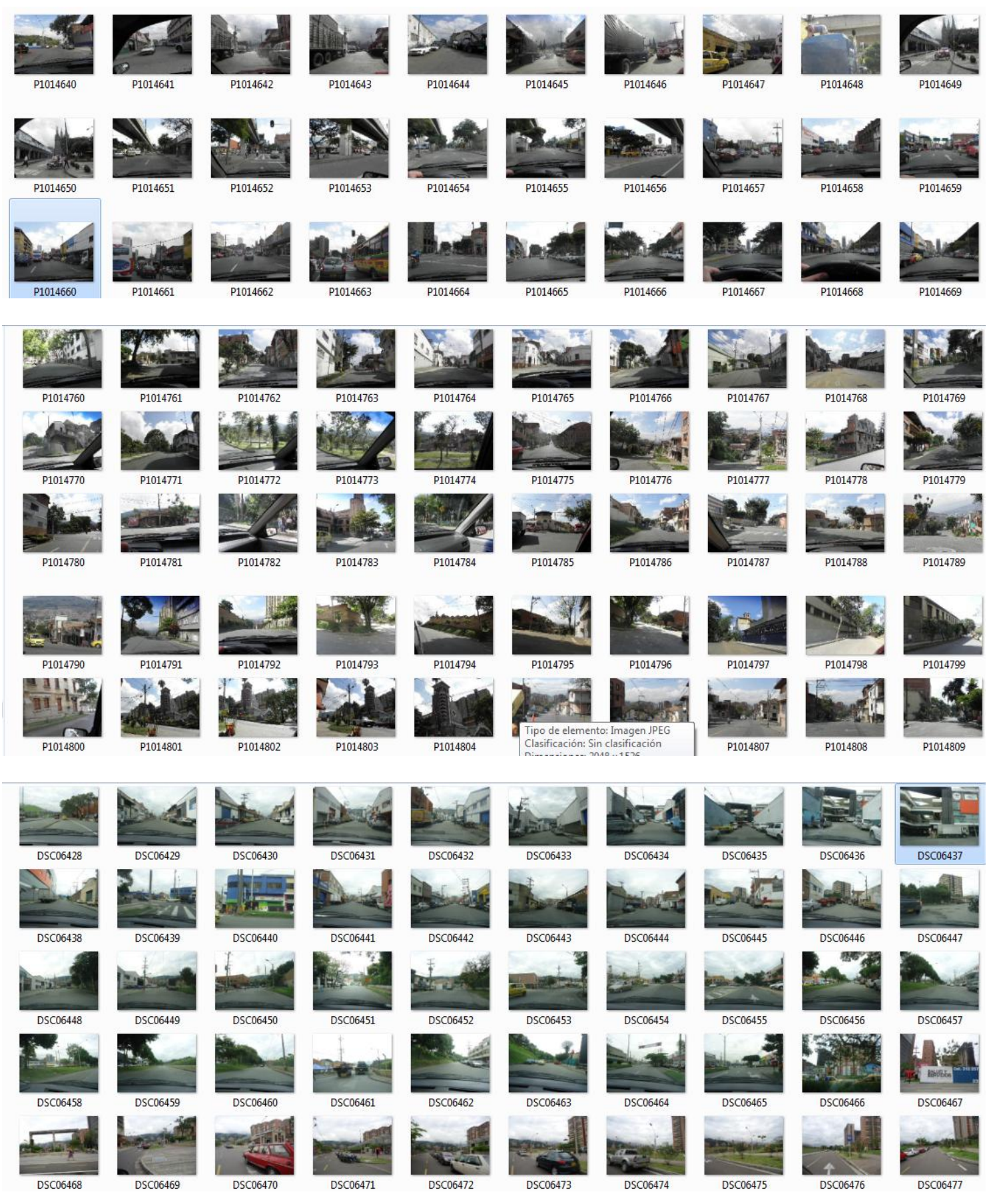




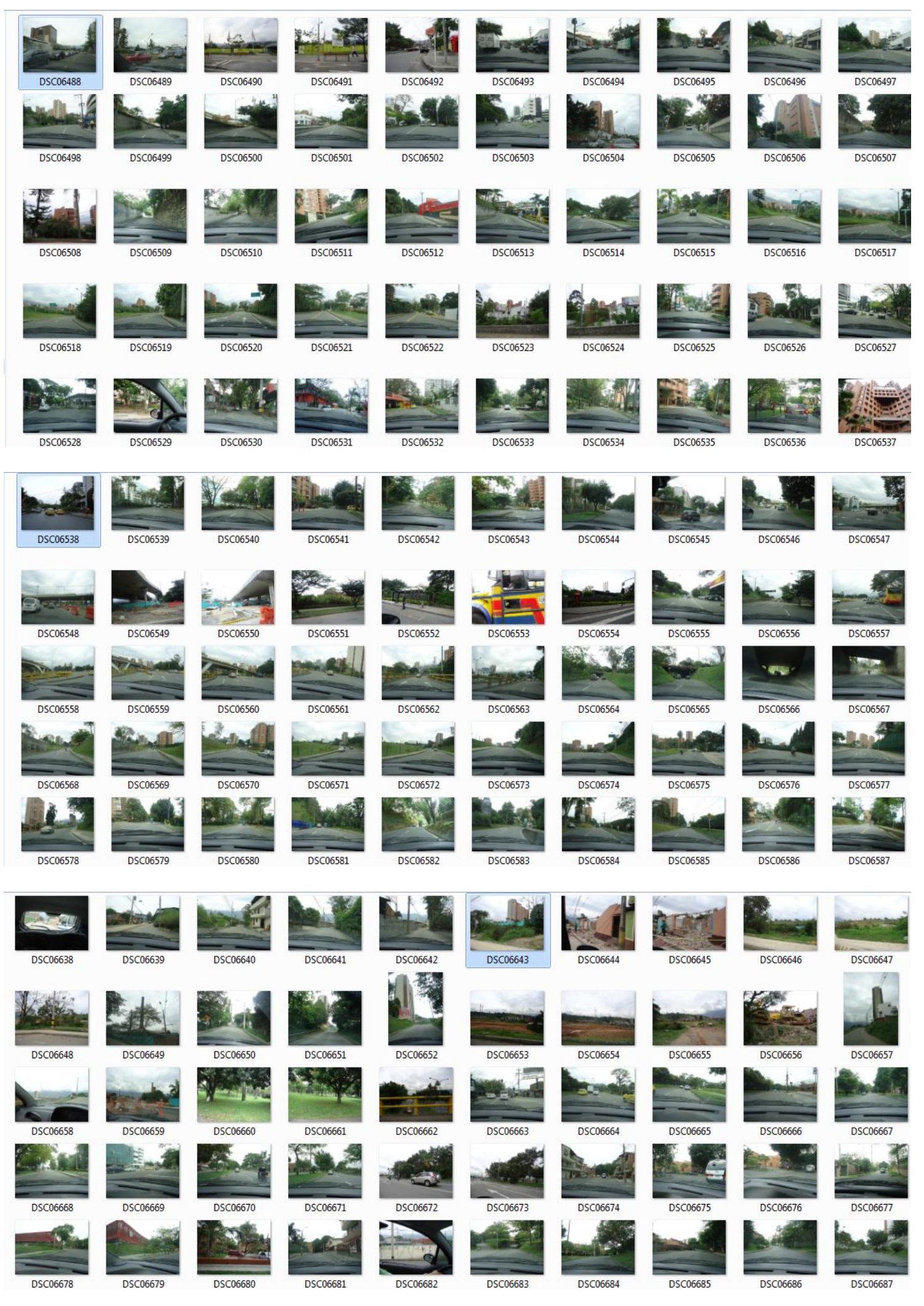


Ilustración 49. Registro fotográfico del recorrido por el paisaje urbano contemporáneo de Medellín a través de los estratos narrativos de 1970 a 2010

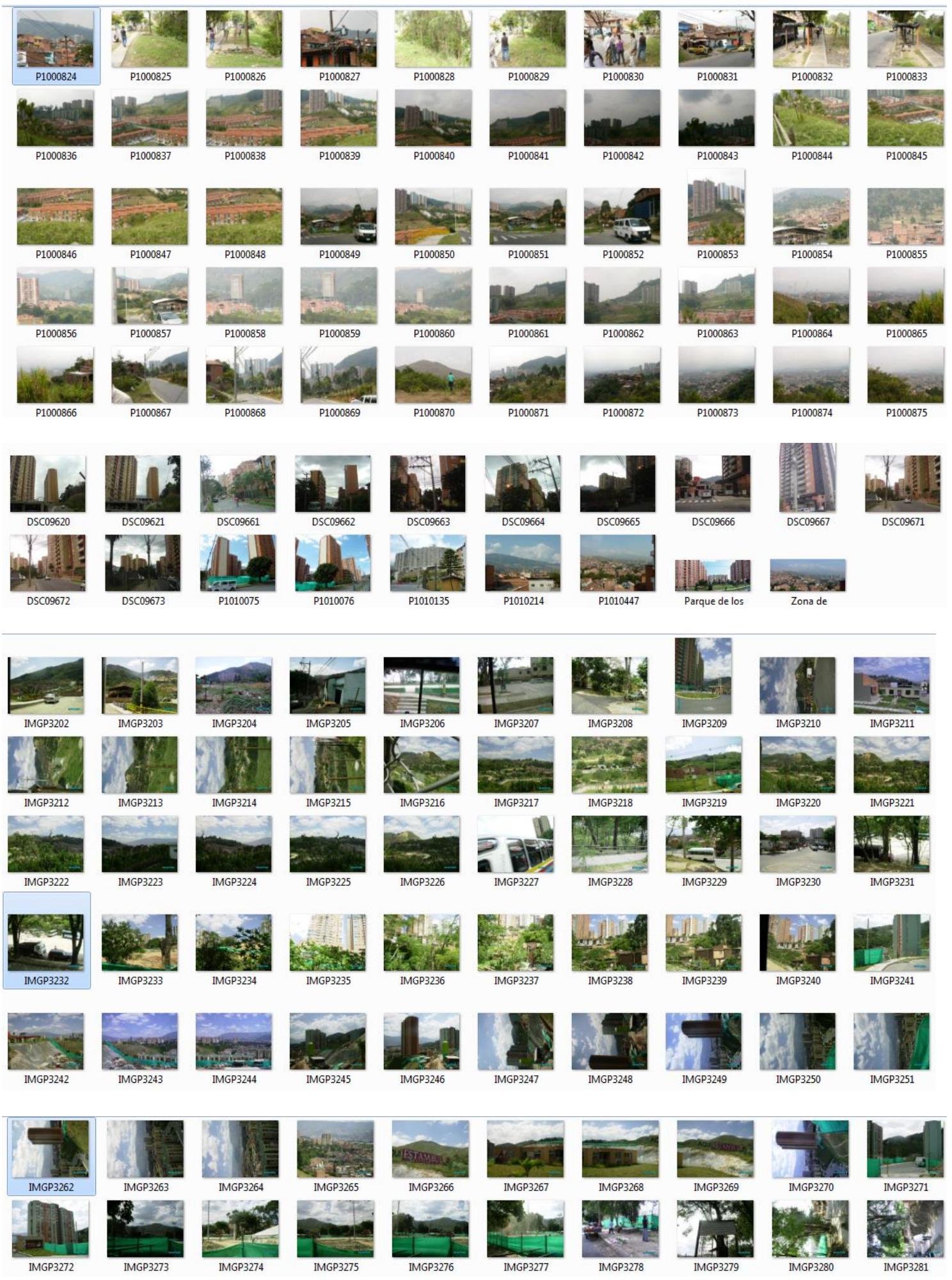




\section{REFERENCIAS BIBLIOGRÁFICAS}

Aprile-Gniset, Jacques (1997). La ciudad colombiana. Santiago de Cali: Universidad del Valle.

Área Metropolitana del Valle de Aburrá y Universidad Pontificia Bolivariana (2007). Estudio de la forma y el crecimiento urbano de la región metropolitana. Medellín: AMVA.

Arias, Pablo (2003). Periferias y nueva ciudad. El problema del paisaje en los procesos de dispersión urbana. Sevilla: Secretariado de publicaciones, Universidad de Sevilla

Barthes, Roland (1977). Introducción al análisis estructural de los relatos. Buenos Aires: Centro Editor de América Latina.

(1993). La aventura semiológica. 2. ${ }^{\text {a }}$ ed. Barcelona: Paidós Ibérica S. A.

(2006). La cámara lúcida. Nota sobre la fotografía. 10. a ed. Barcelona: Paidós Ibérica

S. A.

Berman, Marshall (1991). Todo lo sólido se desvanece en el aire: la experiencia de la modernidad. 5. ${ }^{\mathrm{a}}$ ed. Bogotá: Siglo XXI.

Bermejo, Jesús (2009). "Leyendo los espacios: una aproximación crítica a la sintaxis espacial como herramienta de análisis arqueológico”. Arqueología de la arquitectura. Núm. 6. Madrid.

Botero, Fernando (1996). Medellín 1890-1950: historia urbana y juego de intereses. Medellín: Editorial Universidad de Antioquia.

Ceballos, Juan Carlos y Vélez, Johanna (2002). "De los planes de desarrollo físico a los planes de desarrollo integral”. Habitar y comunicar ... El Rincón. Ensayos Forhum (20). Medellín: Universidad Escuela del Hábitat - CEHAP, Nacional de Colombia, Sede Medellín.

DAPD (2010). "Medellín en cifras”, Medellín.

DAPM (2009). “Observatorio del Suelo y del Mercado Inmobiliario”, Medellín.

Deleuze, Gilles y Félix Guattari (1994). Mil mesetas: capitalismo y esquizofrenia. Valencia: Pre-textos.

Delgado, Manuel (Conferencista) (1995). Seminario sobre trayectos y espacios de la memoria urbana. Medellín, Biblioteca Pública Piloto

(1998). "La ciudad mentirosa". Ciencias Humanas. Núm. 24. Barcelona.

(2010). La ciudad mentirosa. Fraude y miseria del "modelo Barcelona". 2." ed.

Madrid: Catarata.

Donadieu, Pierre (2006). La sociedad paisajista. La Plata: Editorial de la Universidad de La Plata.

Eliade, Mircea (1992). Lo sagrado y lo profano. Barcelona: Labor. 
Fundación Viztaz (s.f.). Un siglo de vida en Medellín. Versión digital. Medellín.

García, Rodrigo (coord.) (2000). El Concejo de Medellín protagonista del desarrollo de la capital antioqueña 1900-1999. Medellín: Concejo de Medellín.

González, Luis Fernando (2007). Medellín, los origenes y la transición a la modernidad: crecimiento y modelos urbanos 1775-1932. Medellín: Universidad Nacional de Colombia.

Gómez, Beatriz (2008). "Procesos de transformación de la ciudad de Medellín, descentramientos, aglomeración, polarización, 2000-2007”. [Ponencia presentada en el VII Seminario Nacional de investigación urbano regional, marzo de 2008]. Medellín: Universidad Nacional de Colombia, Sede Medellín.

Gruzinski, Serge (1995). La guerra de las imágenes: de Cristóbal Colón a Blade Runner (1492-2019). México: Fondo de Cultura Económica.

Hernández F. (2003). Reconnections and Recognitions, urban renewal in the central area of Medellín Colombia. Holanda: Universidad Técnica de Delft.

Jaramillo, Roberto y Verónica Perfetti (1993). Cartografia urbana de Medellín, 1790-1950. Medellín: Concejo de Medellín.

Le Courrier du CNRS, Habitat II (1996). Ciudades, cumbre sobre la ciudad. Núm. 82. Estambul.

Lynch, Kevin (1975). ¿De qué tiempo es este lugar? Para una nueva definición del ambiente. Barcelona: Gustavo Gili S.A.

(1992). Administración del paisaje. Bogotá: Norma.

Mejía, Germán (2000). Los años del cambio: historia urbana de Bogotá, 1820-1910. Bogotá: Pontificia Universidad Javeriana.

Molina, Luis Fernando (2005). Fotografia de arquitectura en Medellín 1870-1960. Medellín: Editorial Universidad de Antioquia.

Municipio de Medellín (2006). Plan de Ordenamiento Territorial, Acuerdo 046 de 2006. Medellín.

(2006). "Plan Especial de Espacio Público y Equipamientos”, Medellín.

(2007). Plan de accesibilidad peatonal del centro. Medellín.

(2010). Medellín en cifras. Núm. 1. Medellín.

Nogué, Joan (ed.) (2008). El paisaje en la cultura contemporánea. Madrid: Editorial Biblioteca Nueva. (ed.) (2007). La construcción social del paisaje. Madrid: Editorial Biblioteca Nueva.

Olea, Óscar (1989). Catástrofes y monstruosidades urbanas. Introducción a la ecoestética. México: Editorial Trillas S.A. 
Ramos, Martín Ángel (ed.) (2004). Lo urbano en 20 autores contemporáneos. Barcelona: Universidad Politécnica de Cataluña.

Ricoeur, Paul (2008). La memoria, la historia, el olvido. 2. ${ }^{\mathrm{a}}$ ed. Buenos Aires: Fondo de Cultura Económica de Argentina S. A.

Rodríguez, Carlos Mario (2009). "Urbanismo Social, Espacio Público y Vivienda en Medellín, transformación de una ciudad” [conversatorio]. Medellín: BID.

Rueda, Salvador (dir.) (2007). Plan especial de indicadores de sostenibilidad ambiental de la actividad urbanistica de Sevilla. Barcelona: Agencia de ecología urbana de Barcelona.

Sennet, Richard (2002). Carne y piedra. El cuerpo y la ciudad en la civilización occidental. 1. reimpresión. Madrid: Alianza Editorial.

SIGAME (2010). Sistema de información geográfica de Medellín. Municipio de Medellín

Silva, Armando (1994). Imaginarios urbanos: Bogotá y Sao Paulo. Cultura y comunicación urbana en

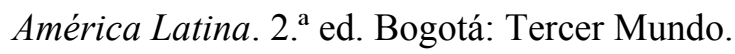

Sontag, Susan (2005). Sobre la fotografía. Bogotá: Alfaguara.

Suramericana de Seguros (1988), Historia de Antioquia. Medellín: Editorial Presencia Ltda.

Uribe, Teresa (1996), "La estructura social de Medellín en la segunda mitad del siglo XIX". Historia de Medellín II. Medellín, Compañía Suramericana de Seguros.

Zuleta, Bethoven (2009). "El hábitat y la internacionalización de la política pública: conflicto y diálogo entre la norma y la regla". Actas del hábitat popular. Octubre de 2009. Medellín: Universidad Nacional de Colombia, Sede Medellín.

\section{Sitios web consultados}

Cubiertec, disponible en: www.cubiertec.com

DesignFun, disponible en: www.designfun.net

Guía de Viajes Oficial de Medellín, disponible en: http://www.medellin.travel/semanasanta2010/

I love Medellín, disponible en: www.ilovemedellin.net

Jardín Botánico, disponible en: http://www.botanicomedellin.org/historia.html

"Medellín, transformación de una ciudad". Sitio web: Scribid, disponible en: http://www.laboratoriomedellin.com/inico/component/tema/vertema/18.html\#urbanismo 
Memoria fotográfica de Medellín, en: http://www.viztaz.com.co/unsiglo/bancodigital/ciudad.htm

Municipio de Medellin, disponible en: http://www.medellin.gov.co/irj/portal/medellin

"Observatorio del Suelo y del Mercado Inmobiliario". Sitio web: Municipio de Medellín, disponible en: http://www.medellin.gov.co/ReportesSite/index.jsp

Panoramio, disponible en: www.panoramio.com

“Planos del Plan Piloto de Medellín (1948)". Sitio web: Archivo Histórico de Medellín, disponible en:

http://ahmedellin.janium.net/janium-bin/sumario.pl?Id=20120430213235

Propuestas in_consultas, en:

http://sancheztaffurarquitecto.wordpress.com/page/26/?archives-list\&archives-type=tags.

Vive tu colombia, disponible en: www.vivetucolombia.com 